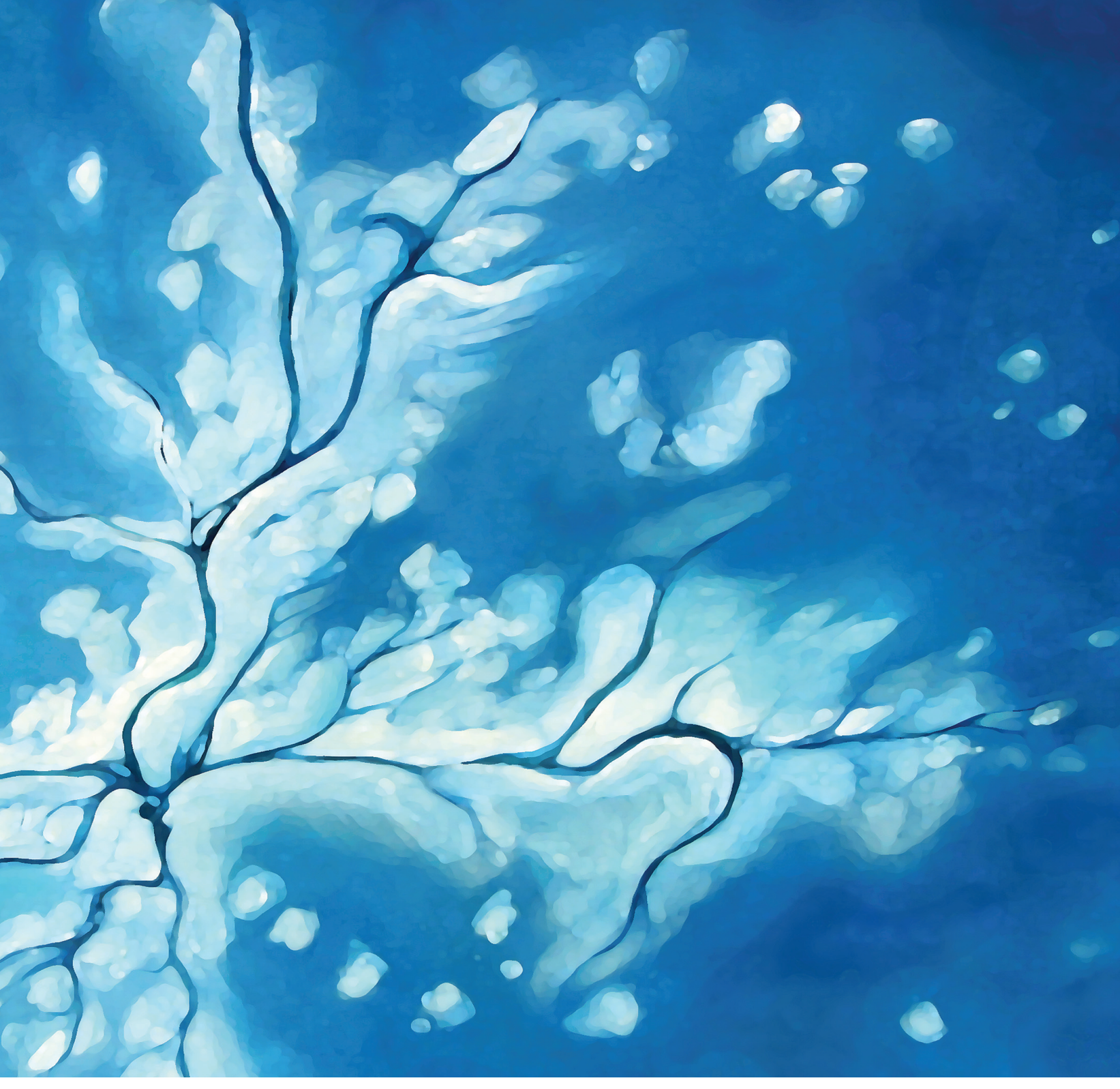




\section{PURE HYDROGEN FROM PYROLYSIS OIL BY THE STEAM-IRON PROCESS}

M. F. BLEEKER 
Promotion committee:

Prof. dr. G. van der Steenhoven, Chairman

University of Twente

Prof. dr. H.J. Veringa, Promotor

University of Eindhoven

Dr. S.R.A. Kersten, Assistant-promotor

University of Twente

Prof. dr. ir. J.A.M. Kuipers

University of Twente

Prof. dr. ir. H. van den Berg

University of Twente

Prof. dr. ir. H.J. Heeres

University of Groningen

Prof. dr. J.A. Moulijn

Delft University of Technology

Prof. dr. ir. W. Prins

Ghent University, Ghent, Belgium

Prof. Z.R. Ismagilov

Boreskov Institute of Catalyisis,

Novosibirsk, Russia

The research reported in this thesis was executed under a grant of the Netherlands Organisation of Scientific Research (NWO) within the platform of Advanced Chemical Technologies for Sustainability (ACTS) in the program "Sustainable Hydrogen".

Cover design: Mariken Bleeker

Front cover is an impression of the enhanced melting of an ice cap due to a blowhole of a seal. (source: National Geographic 2008)

Publisher: Ipskamp Drukkers B.V. P.O. Box 333, 7500 AH Enschede.

(C) 2009 by M.F. Bleeker, Enschede, The Netherlands

No part of this book may be reproduced in any form by print photocopy or any other means without written permission from the author.

ISBN 978-90-365-2888-7 


\title{
PURE HYDROGEN FROM PYROLYSIS OIL BY THE STEAM-IRON PROCESS
}

\section{PROEFSCHRIFT}

\author{
ter verkrijging van \\ de graad van doctor aan de Universiteit Twente, \\ op gezag van de rector magnificus, \\ prof. dr. H. Brinksma, \\ volgens besluit van het College voor Promoties \\ in het openbaar te verdedigen \\ op donderdag 10 september 2009 om 13.15 uur
}

\author{
door \\ Mariken Francisca Bleeker \\ geboren op 5 juni 1978 \\ te Zoetermeer.
}


Dit proefschrift is goedgekeurd door de promotor:

Prof. dr. H.J. Veringa

en de assisitent-promotor:

Dr. S.R.A. Kersten 
Aan Sander 


\section{Contents}

Summary and conclusions

Samenvatting en conclusies

Chapter 2 Review and thermodynamic study of the steam-iron process with pyrolysis oil

Chapter 3 Redox experiments with pyrolysis oil in the fluidized bed (part I)

Chapter 4 Redox experiments with pyrolysis oil in the fluidized bed (part II)

Chapter 5 Observations on the reduction and oxidation of iron oxides with $\mathrm{H}_{2}$ and $\mathrm{H}_{2} \mathrm{O}$

Chapter 6 Deactivation of iron oxide used in the steam-iron process

Chapter 7 Process design study for the production of hydrogen from pyrolysis oil in the steam-iron process 
Appendix A

Appendix B

222

Appendix C

226

Publications

229

Dankwoord

230

About the author

232 



\section{Summary and conclusions}

The steam-iron process is an old process, which was used for the production of hydrogen from cokes at the beginning of the twentieth century. However, the process could not compete with the later on developed steam reforming of methane and the process fell into disuse. The future hydrogen demand is expected to increase, in existing industries and in new technologies like fuel cells. Hydrogen has been produced predominantly by fossil based routes, mostly steam reforming of methane due to its technological maturity, availability of methane and high hydrogen yield. The current use of fossil fuels results in environmental problems and in rapid depletion. Therefore alternative renewable sources, like wind, solar and biomass, are now being considered for the production of hydrogen. Nowadays renewed interest in the development of the steam-iron process is mainly focused on the use of renewable energy sources, like biomass. In this thesis, the production of hydrogen by the steamiron process from pyrolysis oil is studied. Pyrolysis oil, obtained from the pyrolysis of biomass, is used to facilitate transportation and to simplify gasification and combustion processes, before being processed to hydrogen. The benefit of the steamiron process compared to other thermo-chemical routes of biomass, is that hydrogen can be produced in a two step redox cycle, without the need of any purification steps (like HT-shift, LT shift and PSA).

The thermodynamic study in chapter 2 reveals that the application of pyrolysis oil in the steam-iron process is possible for process temperatures above approximately $630{ }^{\circ} \mathrm{C}$, because reduction reactions with oil can take place above this temperature. The efficiencies found at different temperatures $\left(700-950{ }^{\circ} \mathrm{C}\right)$ is comparable with other biomass to hydrogen routes, which are in the range of 50-58 \% (LHV based). An optimum process efficiency is found at temperatures around $730{ }^{\circ} \mathrm{C}$, as at this temperature the reduction and oxidation are energetically best balanced. The expected amount of carbon formed during the inert gasification of pyrolysis oil is during the reduction contributing in the reduction of the iron oxide. To enable this reduction reaction contact between the solid carbon and iron oxide is required. Redox experiments are therefore conducted in a fluidized bed containing iron oxide particles, 
in which the gasification of oil and the reduction of iron oxide are taking place simultaneously.

A fluidized bed is constructed to study pyrolysis oil gasification over a sand and iron oxide bed and the subsequent steam oxidation of reduced iron oxide (Chapter 3). From inert (sand bed) oil gasification experiments it is found that the oil to gas conversion is limited to about $70 \%$. The rest of the oil is converted to low density solid carbonaceous compounds and tars. First redox experiments at $800{ }^{\circ} \mathrm{C}$ showed that the reduction continues after oil injection, which is caused by the carbonaceous compounds deposited on the iron oxide particles during oil injection. The oxidation with hot steam is started when the reduction with the carbonaceous compounds is finalized, resulting in the production of a relatively pure hydrogen gas (97-99 vol\%) after cooling. The use of a porous catalytic iron oxide (named BIC iron oxide), which enhances steam-reforming reactions, resulted in a higher hydrogen production than a non-porous BF iron oxide (blast furnace iron oxide) in the redox cycle. The hydrogen production per kilogram of oil in the redox cycle is strongly affected by the iron oxide to oil ratio applied in the reduction, which can be related to the conversion of the iron oxide. A low conversion of the iron oxide during reduction resulted in a high oil to hydrogen conversion in the redox cycle. Consecutive cycling of the iron oxide resulted in a decrease of the external surface area of the iron oxides and consequently in a decrease of the conversion rates in the oxidation and reduction.

In Chapter 4 the study of iron oxide reduction and oxidation in the fluidized bed with pyrolysis oil is continued by studying the effect of temperature and conversion of the iron oxide on the conversion rate in the reduction. The hydrogen production in the redox cycle increases when high temperatures up to $950{ }^{\circ} \mathrm{C}$ are applied. Equilibrium hydrogen productions in the redox cycle with oil are obtained when the conversion of the iron oxide in the reduction is low (less than $7 \%$ of the conversion of magnetite to wustite is achieved) and the temperature is above $900{ }^{\circ} \mathrm{C}$. A high temperature improves the gasification of oil to reducing gases like $\mathrm{CO}$ and $\mathrm{H}_{2}$, enhances the conversion of oil to the gas phase and results in more advantageous equilibrium reduction conditions. A near complete oil to gas conversion is obtained with the BIC iron oxide at temperatures above $900{ }^{\circ} \mathrm{C}$. Thermo gravimetric analysis of oil/BIC iron oxide samples showed that the reduction of iron oxide with the carbonaceous compounds is fast at temperatures above $850{ }^{\circ} \mathrm{C}$. The fast reduction 
reaction with carbon at temperatures higher than $850{ }^{\circ} \mathrm{C}$ results in the conversion of all formed solid carbonaceous compounds to the gas phase during oil injection. The drastic decrease of the conversion rate during reduction with increasing conversion of the iron oxide could not be understood with known particle models (describing the relative conversion rate with changing conversion). Deactivated BIC iron oxide with a very low external surface area is applied in these experiments and as a result diffusional limitations in the particle occur already at a low conversion, resulting in a low conversion rate when the particle is partly reduced. To keep a high conversion rate during the reduction a highly porous iron oxide is required. The strong decrease in conversion rate is also caused by the low maximum conversion of the iron oxide in the experiments, which is determined by the reducing capacity of the oil and the temperature. A full conversion to wustite could not be achieved in the experiments. The oxidation of deactivated BIC iron oxide is slow when the conversion to magnetite is nearly completed. The slow oxidation is a result of the low porosity of the deactivated BIC iron oxide. The equilibrium steam conversion can only be obtained at the onset of the oxidation and when a high relative conversion in the reduction is achieved. A near complete oxidation to magnetite is required in the steam-iron process, to enable the following reduction with pyrolysis oil. A large oxidation reactor would be required, to achieve a near complete oxidation to magnetite and to obtain an equilibrium steam conversion.

The experiments in the fluidized bed are not suitable to study the reduction and oxidation reaction on a particle level. Therefore a packed bed is constructed to study the redox reaction with hydrogen and steam as model compounds (Chapter 5). The reduction is performed in a temperature ramp and isothermally, from which the isothermal experiments could be used to study the reactions taking place in the steamiron process. In all reduction and subsequent oxidation experiments fresh material is used, to avoid influences of previous observed deactivation upon cycling. The conversion rate during reduction of the non-porous BF iron oxide is very low, which is attributed to the presence of silicate, slowing down solid state diffusion in the iron oxide and resulting in the formation of iron silicates. The reduction of the BF iron oxide becomes limited by a diffusion resistance when iron is formed upon reduction. Furthermore the high temperature applied $\left(>600^{\circ} \mathrm{C}\right)$ results in sintering of the iron oxide during reduction. Sintering of the $\mathrm{BF}$ iron (oxide) during reduction leads to a slow conversion rate in the consecutive oxidation, especially when high reaction 
temperatures are applied. In this case the oxidation rate becomes extremely slow when the conversion to magnetite is nearly completed. The high initial porosity of the BIC iron oxide enables a high conversion rate in both reduction and oxidation. The presence of chromium oxide in this iron oxide lowers sinter rates during reduction, whereby the porosity of the iron oxide is partly maintained. The porosity of the iron oxides strongly influences the conversion rates, especially during oxidation. The difference in porosity between the BF and BIC iron oxide and the presence of silicon oxide in the $\mathrm{BF}$ iron oxide explain the difference in the results obtained with both iron oxide in the fluidized bed (Chapter 3).

The deactivation of the iron oxide during subsequent cycling is studied in the packed bed set-up in Chapter 6. Isothermal redox cycles using hydrogen and steam in the reduction and oxidation are studied to determine the deactivation of the BIC iron oxide, as this material has an initial high porosity. Deactivation is mainly caused by the shrinking and swelling of the material during cycling, resulting in an enhanced sintering of the iron oxide particles. The deactivation rate is related to the conversion of the iron oxide in the redox cycle; the deactivation rate is slow when the conversion is low (limited shrinking and swelling). The observed decrease in surface area of the particles upon cycling could be described with a sintering model for low conversion of the iron oxide in the redox cycle. The measured deactivation could also be interpreted with the grainy pellet model (adjusted for the swelling of the material during oxidation) applied on the measured conversion rate in the oxidation. Fitting the measured conversion rate in the oxidation with the grainy pellet model, results in a prediction of the grain growth and an increase of the solid fraction over subsequent cycles. SEM pictures confirmed the grain growth visually and BET analysis confirmed the predicted increase of the grain diameter with the grainy pellet model over subsequent cycles. Due to the deactivation of the iron oxide the conversion rate in the oxidation becomes limited by pore diffusion of steam in the particle.

A low conversion of the iron oxide is beneficial for both a low deactivation rate and a high pyrolysis oil to hydrogen production. However, the large amount of iron oxide required per kilogram of oil will than have a negative effect on the process economy, as a lot of material has to be transported between the oxidation and reduction reactor. To reduce the amount of iron oxide required a high porosity of the material is needed and deactivation should be prevented. Incorporation of an inert material to a certain extent to keep a significant amount of the iron oxide grains apart 
can be a remedy to reduce enhanced sintering effects. In this way lower deactivation rates, even with higher conversions, may be expected.

In the final chapter (Chapter 7) a process design study is performed for the steam-iron process with pyrolysis oil based on the obtained experimental results. The process efficiency is evaluated at 800 and $920{ }^{\circ} \mathrm{C}$ using experimental and theoretical data (based on thermodynamics) for the reduction.

The use of pyrolysis oil in the steam-iron process for the production of hydrogen is energy efficient ( $53 \% \mathrm{LHV}$ at $\left.800{ }^{\circ} \mathrm{C}\right)$, based on equilibrium calculations. Experimental results showed that this theoretical maximum efficiency could not be achieved with deactivated BIC iron oxide. In practice a good reduction with pyrolysis requires temperatures higher than $850^{\circ} \mathrm{C}$ as in this case the formed solid carbonaceous compounds contribute in the reduction. However, at these temperatures, the unfavorable low equilibrium steam conversion in the oxidation becomes a bottleneck for energy efficient processing. After the oxidation with steam, the hydrogen product is separated from the $\mathrm{H}_{2} / \mathrm{H}_{2} \mathrm{O}$ mixture by condensing the steam fraction in a condenser, resulting in a substantial energy loss, as the condensation enthalpy cannot be recovered. Simulations show that the process efficiency at high temperatures can be substantially improved, by performing the redox cycle at a high pressure and by using membranes to separate the $\mathrm{H}_{2}$ from the $\mathrm{H}_{2} / \mathrm{H}_{2} \mathrm{O}$ mixture. In this case the loss of energy due to the condensation of unreacted steam can be avoided.

The steam-iron process with pyrolysis oil is presumed to be a simple thermochemical process to produce pure hydrogen from biomass, as no purification steps are required. However the operation of a steam-iron plant, in which large amounts of iron oxide are being circulated between reductor and oxidator may not be easy and economical. The amount of iron oxides circulating in the process can be reduced when the iron oxide improves to maintain high conversion rates in reduction and oxidation, while obtaining a high conversion to wustite in subsequent redox cycles. If such an iron oxide is found, energy efficiencies comparable to other biomass to hydrogen processes can be obtained.

Besides this, the objective of producing $100 \%$ pure hydrogen may not be obtained with the proposed process in which oil gasification and reduction take place simultaneously. The solid carbonaceous compounds formed on the iron oxide will be difficult to convert entirely in practice (especially at temperatures below $900{ }^{\circ} \mathrm{C}$ ), which would result in the necessity to use a stripping section. Once purification steps 
like this are required in the process it will become impossible to be competitive with existing biomass to hydrogen processes.

Research on this topic however yielded interesting results, for example the high conversion of oil when gasified in an iron oxide bed, which can be of use in other pyrolysis oil gasification processes. The deactivation model can be applied in other redox processes like chemical looping combustion. 


\section{Samenvatting en conclusies}

Het stoom-ijzer proces is een oud proces, dat voor de productie van waterstof werd gebruikt aan het begin van de $20 \mathrm{e}$ eeuw. Het proces kon echter niet concurreren met de productie van waterstof door middel van stoomreformen uit methaan, waardoor het proces uiteindelijk niet meer werd gebruikt.

De toekomstige vraag naar waterstof wordt verwacht toe te nemen in huidige industrieën, maar ook in nieuwe technologieën, zoals in brandstofcellen. Waterstof wordt nu hoofdzakelijk geproduceerd uit fossiele grondstoffen, waarvan stoomreformen van methaan het meest gebruikt wordt. Dit komt met name door de volwassenheid van deze technologie, de beschikbaarheid van methaan en de hoge waterstof opbrengst. Het huidige gebruik van fossiele bronnen leidt tot milieu problemen en tot snelle uitputting van deze bronnen. Daarom wordt er tegenwoordig gekeken naar het gebruik van alternatieve hernieuwbare bronnen, zoals wind, zon en biomassa, voor de productie van waterstof.

Op dit moment is er opnieuw interesse in de ontwikkeling van het stoom-ijzer proces, dat hoofdzakelijk is gericht op het gebruik van hernieuwbare bronnen, waaronder biomassa. In dit proefschrift wordt de productie van waterstof met het stoom-ijzer proces uit pyrolyse olie bestudeerd. Pyrolyse olie, verkregen uit de pyrolyse van biomassa zoals hout, wordt gebruikt om het transport van biomassa efficiënter te maken en om vergassings- en verbrandingsprocessen te versimpelen voordat de productie van waterstof plaatsvindt. Het voordeel van het stoom-ijzer proces, vergeleken met andere thermo-chemische routes met biomassa, is dat de waterstof geproduceerd kan worden in een twee-staps redox cyclus zonder de noodzaak van zuiveringsstappen (zoals HT-shift, LT shift en PSA).

Een thermodynamische studie in hoofdstuk 2 laat zien dat de toepassing van pyrolyse olie in het stoom-ijzer proces mogelijk is voor temperaturen boven ongeveer $630{ }^{\circ} \mathrm{C}$, omdat boven deze temperatuur reductie reacties met vergassingsproducten van de olie kunnen plaatsvinden. De gevonden efficiëntie bij verschillende proces temperaturen $\left(700-950{ }^{\circ} \mathrm{C}\right)$ is vergelijkbaar met andere thermo-chemische routes waarin waterstof geproduceerd wordt uit biomassa, welke tussen de 50-58 \% liggen (gebaseerd op LHV). 
Een optimale proces efficiëntie is gevonden bij een temperatuur van ongeveer $730{ }^{\circ} \mathrm{C}$, omdat op deze temperatuur de reductie en oxidatie het beste met elkaar in balans zijn. De verwachte hoeveelheid koolstof, die gevormd wordt tijdens de inerte vergassing van pyrolyse olie, draagt in deze berekeningen bij in de reductie van het ijzeroxide. Om deze reactie mogelijk te maken moet er contact zijn tussen het vaste koolstof en het ijzeroxide. Redox experimenten zijn daarom uitgevoerd in een wervelbed met ijzeroxide deeltjes, waarin de vergassing van olie en de reductie van het ijzeroxide tegelijk kunnen plaatsvinden.

De vergassing van pyrolyse olie over zand deeltjes en ijzeroxide deeltjes en de daarop volgende oxidatie met stoom van de gereduceerde ijzeroxide deeltjes is bestudeerd in een daarvoor vervaardigde wervelbed reactor (hoofdstuk 3). Uit de inerte (zand bed) olie vergassing experimenten is gevonden dat de olie naar gas conversie gelimiteerd is tot ongeveer $70 \%$. De rest van de olie wordt omgezet naar vaste koolstofhoudende componenten met een lage dichtheid en teren. De eerste redox experimenten op $800{ }^{\circ} \mathrm{C}$ hebben laten zien dat de reductie ook verloopt wanneer de olie toevoer is gestopt, wat veroorzaakt wordt door de reactie van ijzeroxide met de koolstofhoudende componenten, die zich hebben afgezet op het ijzeroxide tijdens de toevoer van olie. De oxidatie met hete stoom wordt gestart wanneer de reductie met de koolstofhoudende componenten afgelopen is, wat resulteert in de productie van een relatief puur waterstof gas (97-99 vol\%) na het koelen van de productstroom. Het gebruik van een poreus katalytisch ijzeroxide (BIC ijzeroxide), die onder andere stoom reform reacties verbeterd, resulteert in een hogere waterstof opbrengst vergeleken met het gebruik van een niet poreus hoogoven ijzeroxide (BF ijzeroxide) in een redox cyclus. De waterstof productie per kilogram olie in de redox cyclus wordt sterk beïnvloed door het ijzeroxide /olie ratio die toegepast is tijdens de reductie. Dit ratio is gerelateerd aan de omzetting van het ijzeroxide behaald in de reductie. Een lage conversie van het ijzeroxide tijdens de reductie resulteert in een hoge waterstof productie in de redox cyclus. Het uitvoeren van opeenvolgende redox cycli met ijzeroxide resulteert in een afname van het externe oppervlak van de ijzeroxide deeltjes en daardoor in een afname van de omzettingssnelheid in de oxidatie en reductie.

In hoofdstuk 4 is de studie naar de reductie en oxidatie van ijzeroxide met pyrolyse olie in het wervelbed voortgezet, door het effect van de temperatuur en de 
conversie van het ijzeroxide op de omzettingssnelheid in de reductie te bestuderen. De waterstof productie in de redox cyclus neemt toe wanneer hoge temperaturen tot 950 ${ }^{\circ} \mathrm{C}$ worden toegepast. Een hoge waterstof productie, waarbij evenwicht wordt behaald in de reductie met olie, kan worden behaald wanneer de conversie van het ijzeroxide in de reductie laag is (de conversie van magnetiet naar wüstiet moet kleiner zijn dan $7 \%$ ) en de temperatuur boven de $900{ }^{\circ} \mathrm{C}$ is. Een hoge temperatuur verbetert de vergassing van olie naar reducerende gassen zoals $\mathrm{CO}$ en $\mathrm{H}_{2}$, verbetert de conversie van olie naar de gas fase en resulteert daarnaast in betere evenwichtscondities voor de reductie reactie. Een vrijwel volledige olie naar gas conversie is behaald met BIC ijzeroxide bij temperaturen boven de $900{ }^{\circ} \mathrm{C}$. Thermo-gravimetrische analyses van mengsels van olie en BIC ijzeroxide hebben laten zien dat de reductie van ijzeroxide met koolstofhoudende componenten plaatsvindt wanneer temperaturen boven de 850 ${ }^{\circ} \mathrm{C}$ worden gebruikt. De snelle reactie van ijzeroxide met koolstof bij temperaturen boven de $850{ }^{\circ} \mathrm{C}$ resulteert in een omzetting van alle vaste koolstofachtige componenten naar de gas fase tijdens olie injectie. De geobserveerde snelle afname van de omzettingssnelheid tijdens de reductie door de toenemende conversie van het ijzeroxide kon niet beschreven worden met bestaande deeltjes modellen (die de relatieve omzettingssnelheid beschrijven bij een veranderende conversie van het ijzeroxide). In deze experimenten is gedeactiveerd BIC ijzeroxide gebruikt, met een laag specifiek oppervlak, waardoor diffusie limiteringen in het ijzeroxide deeltje al kunnen optreden wanneer het ijzeroxide deeltje nog maar nauwelijks heeft gereageerd. Dit resulteert in een lage omzettingssnelheid wanneer het ijzeroxide deeltje nog maar gedeeltelijk is omgezet. Een ijzeroxide deeltje met een hoge porositeit is nodig om een hoge omzettingssnelheid te behouden tijdens de reductie. De sterke afname van de omzettingssnelheid wordt ook veroorzaakt door de lage maximaal behaalbare conversie van het ijzeroxide deeltje, die wordt bepaald door het reducerende vermogen van de olie en de temperatuur. Een volledige conversie naar wüstiet is niet behaald in de experimenten.

De oxidatie van gedeactiveerd BIC ijzeroxide is traag wanneer de volledige conversie naar magnetiet bijna behaald is. De trage oxidatie is een resultaat van de lage porositeit van het gedeactiveerde BIC ijzeroxide. De stoom conversie bij evenwicht kan alleen worden behaald aan het begin van de oxidatie en wanneer een hoge conversie van het ijzeroxide is behaald in de reductie. Een hoge conversie naar magnetiet in de oxidatie is nodig in het stoom-ijzer proces om een daarop volgende reductie goed te laten verlopen. Een grote oxidatie reactor zou nodig zijn om een 
volledige oxidatie naar magnetiet en een stoom conversie op evenwicht te kunnen halen.

De experimenten uitgevoerd in het wervelbed kunnen niet worden gebruikt om de reductie en oxidatie reacties op een deeltjes niveau te bestuderen. Daarom is een gepakt bed gebouwd waarin de redox reacties met waterstof en stoom als model componenten kunnen worden bestudeerd (hoofdstuk 5). De reductie is uitgevoerd in een situatie waarin de temperatuur gecontroleerd toeneemt en waarin de temperatuur constant is (isotherm). De isotherme experimenten zijn gebruikt om de reductie en oxidatie reactie, die plaatsvinden in het stoom-ijzer proces, te beschrijven. In alle experimenten zijn de reductie en de daarop volgende oxidatie uitgevoerd met ongebruikte ijzeroxide deeltjes, om de invloed van deactivatie te vermijden. De omzettingssnelheid tijdens de reductie van het niet-poreuse BF ijzeroxide is laag, wat is toegeschreven aan de aanwezigheid van silicaten, die de ion diffusie in het ijzeroxide vertragen en resulteren in de vorming van ijzer silicaten. De reductie van het BF ijzeroxide wordt gelimiteerd door een diffusie weerstand wanneer ijzer wordt gevormd tijdens de reductie. Verder veroorzaakt de hoge temperatuur in de experimenten $\left(>600{ }^{\circ} \mathrm{C}\right)$ het sinteren van het ijzeroxide. Het sinteren van het $\mathrm{BF}$ ijzer(oxide) dat plaatsvindt tijdens de reductie leidt tot een trage oxidatie snelheid in de daarop volgende oxidatie, met name wanneer hoge temperaturen worden toegepast en de oxidatie naar magnetiet bijna volledig is. Door de hoge porositeit van het BIC ijzeroxide is de omzettingssnelheid in zowel reductie en oxidatie hoog. Door de aanwezigheid van chroomoxide wordt het sinteren van het BIC ijzeroxide vertraagd, waardoor de hoge porositeit gedeeltelijk wordt behouden tijdens de reductie. De porositeit van het ijzeroxide heeft een grote invloed op de omzettingssnelheid, met name tijdens de oxidatie. Het verschil in porositeit tussen het BF en BIC ijzeroxide en de aanwezigheid van silicium oxide in het BF ijzeroxide verklaren de resultaten behaald in het wervelbed met beide ijzeroxiden (hoofdstuk 3).

De deactivatie van ijzeroxide in opeenvolgende cycli is bestudeerd in de gepakte bed opstelling in hoofdstuk 6. Isotherme redox cycli met waterstof en stoom zijn bestudeerd om de deactivatie van het BIC ijzeroxide, welke een hoge porositeit heeft, te bepalen. De deactivatie wordt grotendeels veroorzaakt door het krimpen en zwellen van het ijzeroxide in de opeenvolgende cycli, wat resulteert in een versnelde sintering van het materiaal. De snelheid waarmee het ijzeroxide deactivateert is gerelateerd aan de behaalde conversie van het ijzeroxide in de redox cycli; de 
deactivatie is langzaam wanneer de conversie laag is (weinig krimp en zwelling). De geobserveerde afname van het oppervlak van de deeltjes in de opeenvolgende cycli kan beschreven worden met een sinter model bij een lage conversie van het ijzeroxide. De gemeten deactivatie kan ook geïnterpreteerd worden met het "grainy pellet" model (aangepast voor het zwellen dat plaatsvindt tijdens de oxidatie), die toegepast kan worden op de gemeten omzettingssnelheid in de oxidatie. Door de gemeten omzettingssnelheid in de oxidatie te passen met het "grainy pellet" model kan een voorspelling verkregen worden van de groei van de korrel (grains) grootte en de toename van de vaste stof fractie in het deeltje in opeenvolgende cycli. SEM afbeeldingen gaven een visuele bevestiging van de toename van de korrelgrootte en BET analyses bevestigden de voorspelde toename in de korrelgrootte verkregen uit het "grainy pellet" model in de opeenvolgende cycli. Door de deactivatie van het ijzeroxide wordt de omzettingssnelheid in de oxidatie gelimiteerd door porie diffusie van stoom in het deeltje.

Een lage conversie van het ijzeroxide is voordelig voor zowel een lage deactivatie snelheid en een hoge pyrolyse olie naar waterstof conversie in de redox cyclus. Echter de grote hoeveelheid ijzeroxide die nodig is per kilogram olie zal een negatieve invloed hebben op de proces economie, omdat er in dat geval een grote hoeveelheid materiaal tussen reductie en oxidatie reactor getransporteerd moet worden. Om de hoeveelheid ijzeroxide te verlagen is een ijzeroxide met een hoge porositeit noodzakelijk en moet deactivatie van het ijzeroxide worden voorkomen. Toevoeging van een inert materiaal om de ijzeroxide korrels grotendeels uit elkaar te houden zou een oplossing kunnen zijn om het sinteren te verminderen. Op deze manier kunnen lagere deactivatie snelheden worden verwacht, zelfs wanneer een hoge conversie van het ijzeroxide wordt behaald.

In het laatste hoofdstuk (hoofdstuk 7) is een proces ontwerp studie voor het stoom-ijzer proces met pyrolyse olie uitgevoerd. De proces efficiëntie is geëvalueerd bij 800 en $920{ }^{\circ} \mathrm{C}$, waarbij zowel experimentele als theoretische (gebaseerd op thermodynamica) gegevens zijn gebruikt. Het gebruik van pyrolyse olie in het stoomijzer proces voor de productie van waterstof is efficiënt $\left(53 \%\right.$ LHV bij $\left.800{ }^{\circ} \mathrm{C}\right)$, wanneer de berekeningen zijn gebaseerd op evenwicht. De experimentele gegevens laten zien dat de theoretische maximale efficiëntie niet kan worden behaald met gedeactiveerd BIC ijzeroxide. In de praktijk zal voor een goede olievergassing temperaturen hoger dan $850{ }^{\circ} \mathrm{C}$ nodig zijn, omdat in dit geval koolstofhoudende 
componenten op het ijzeroxide snel kunnen reageren met het ijzeroxide. Echter bij deze hoge temperaturen is de stoomconversie bij evenwicht laag, wat een knelpunt zal zijn om het proces energetisch gezien efficiënt uit te kunnen voeren. Na de oxidatie wordt het waterstof product gescheiden van de $\mathrm{H}_{2} / \mathrm{H}_{2} \mathrm{O}$ productstroom door middel van condensatie van de stoomfractie, wat resulteert in een verlies van energie, doordat de condensatie enthalpie van stoom niet kan worden teruggewonnen. Simulaties laten zien dat de energetische efficiëntie van het proces bij hoge temperaturen kan worden verbeterd wanneer de redox cyclus op hoge druk wordt uitgevoerd en membranen worden gebruikt voor de scheiding van het waterstof van de $\mathrm{H}_{2} / \mathrm{H}_{2} \mathrm{O}$ productstroom. In dit geval wordt het verlies van energie door de condensatie van stoom voorkomen.

Het stoom-ijzer proces met pyrolyse olie wordt veronderstelt een simpel thermo-chemisch proces te zijn voor de productie van waterstof uit biomassa, omdat geen zuiveringsstappen nodig zijn. Echter de werking van een stoom-ijzer fabriek, waarin een grote hoeveelheid ijzeroxide wordt rondgepompt tussen een reductie en oxidatie reactor zal waarschijnlijk niet simpel en economisch zijn. De hoeveelheid ijzeroxide die wordt gecirculeerd kan worden verminderd wanneer het ijzeroxide wordt verbeterd zodanig, dat de omzettingssnelheden in reductie en oxidatie hoog zijn terwijl een hoge conversie van het ijzeroxide naar wüstiet in de reductie wordt behaald in opeenvolgende cycli. Als een ijzeroxide met deze eigenschappen kan worden gemaakt, kan een energetische efficiëntie vergelijkbaar met andere biomassa naar waterstof processen worden behaald. Daarnaast zal het doel om vrijwel puur waterstof te maken niet haalbaar zijn wanneer de reductie en vergassing van olie beide in de reductie reactor plaatsvinden. Het zal moeilijk zijn om de praktijk alle vaste koolstofhoudende componenten op het ijzeroxide om te zetten (met name bij procestemperaturen onder de $900{ }^{\circ} \mathrm{C}$ ), waardoor het noodzakelijk zal zijn om alsnog een scheidingsstap te gebruiken om het gas te reinigen. Wanneer zuiveringsstappen nodig zijn om een voldoende zuiver gas te verkrijgen in het stoom-ijzer proces, zal het nog moeilijker worden om te kunnen concurreren met bestaande biomassa naar waterstof technologieën.

Onderzoek op dit onderwerp heeft wel interessante resultaten gegeven die kunnen worden toegepast in andere processen. Zoals de hoge omzet van olie naar gas wanneer een wervelbed met ijzeroxide wordt gebruikt, wat kan worden toegepast in andere pyrolyse olie vergassingsprocessen. Het deactivatie model kan worden toegepast in andere redox processen zoals "chemical looping combustion". 


\section{Chapter 1}

\section{General introduction}




\subsection{Introduction}

The current worldwide hydrogen production approximates 50 million tons per year [1]. About $50 \%$ is used in the ammonia industry, $36 \%$ oil refining and $8 \%$ in methanol production. Most of the hydrogen for these processes is produced on-site and only a small fraction, $6 \%$, is consumed in chemical, food and metallurgical industries. Future demands for hydrogen are expected to increase, in existing industries and in new technologies like fuel cells. The increased refinery demand is driven by the need to produce cleaner transportation fuels in order to meet environmental regulations (e.g., low sulfur requirements) while the input slate continually shifts toward processing heavier crude [2]. Next to this, other growing sectors like fertilizers, biofuels and metallurgy will contribute to the increase in demand. There may be also a future demand of hydrogen as a transportation fuel in fuel cell driven vehicles. An amount of 111 million tons of hydrogen needed for transportation only in the year 2050 in the USA is a prognosis that shows a possible immense growth [1]. Main reasons for using hydrogen as a transportation fuel lie in the fact that local emissions can be avoided, (like $\mathrm{CO}$, Particulate matter, $\mathrm{NO}_{\mathrm{x}}$ etc.) and that high efficiencies can be obtained in the fuel cell. Both advantages using hydrogen are based on the end-use technology. Though, efficient renewable hydrogen production and hydrogen storage are the bottlenecks in making the entire well to wheel chain efficient [3]. To cover the projected hydrogen demand it is necessary to improve the hydrogen recovery in refineries and, eventually, to utilize other potential sources.

At this moment hydrogen is predominantly ( $48 \%$ ) produced by the steam reforming of methane [4]. The price of this methane-based hydrogen depends for $70 \%$ or more on the price of the feedstock. In response to the increasing demand of hydrogen and the problems that go along with the use of fossil fuels, renewable alternatives, like biomass feedstocks, are being considered. Agricultural and forestry wastes are estimated to be energy equivalent to half of the current world's oil production [5]. This indicates that the potential of biomass as a $\mathrm{CO}_{2}$ neutral feedstock for chemicals, fuels and hydrogen production is considerable. Hydrogen produced out of biomass can be used for all current applications including fuel cells. It is however also necessary to produce bio-based hydrogen to enable other biomass-to-fuel production routes. Diesel fuels, for example, can be produced by the Fischer-Tropsch process [6] from bio-based synthesis gas. However, the ratio of $\mathrm{H}_{2} / \mathrm{CO}$ obtained by 
biomass gasification is typically between 0.8 and 1.6 while a $\mathrm{H}_{2} / \mathrm{CO}$ ratio of at least 2 is required for Fischer-Tropsch synthesis [7]. Another example is the co-feeding/coprocessing of liquefied biomass in a crude oil refinery. In this route hydrogen is required for deoxygenation and to increase the $\mathrm{H} / \mathrm{C}$ ratio of bio-liquids [8].

Production processes for hydrogen out of biomass can be divided into biological/ bio-chemical and thermo-chemical processes, with or without use of a catalyst. Proposed thermo-chemical routes for producing hydrogen from solid biomass contain a substantial amount of different reaction steps (Figure 1.1) [13], mainly to purify the hydrogen from gaseous and solid byproducts. In the high temperature shift (HT shift) and low temperature shift (LT shift) $\mathrm{CO}$ reacts with steam to $\mathrm{CO}_{2}$ and $\mathrm{H}_{2}$. The $\mathrm{CO}_{2}$ is finally separated from the hydrogen product by pressure swing adsorption (PSA). Thermal efficiencies for hydrogen production via gasification are estimated to range from 50 to $58 \%$ on HHV basis $[9,10]$.

Biomass can be converted into pyrolysis oil by the fast pyrolysis process, before using it in the production of hydrogen. Liquefying biomass with the pyrolysis process results in a better intermediate energy carrier with a higher volumetric energy density compared to solid biomass (typically $20 \mathrm{GJ} / \mathrm{m}^{3}$ compared to $4 \mathrm{GJ} / \mathrm{m}^{3}$ ) $[11,12]$. Other advantage of pyrolysis oil compared to solid biomass are; I) it contains hardly any metals or minerals, and therefore reduces negative effects on catalysts, like poisoning, when being processed; II) the possibility to recover the minerals and return them to the soil as essential nutrients at the biomass production area; III the decentralised production of pyrolysis oil enables an efficient transportation to central sites for further applications. However, it does not meet the requirements of a transportation fuel [11] and further upgrading or processing of pyrolysis oil is required. Furthermore the energy efficiency of the pyrolysis process is in the range of $70 \%$, thus the mentioned benefits should outweigh the loss of energy in the pyrolysis process.

The route in which biomass is converted to hydrogen directly or via the production of pyrolysis oil is shown in Figure 1.1. 


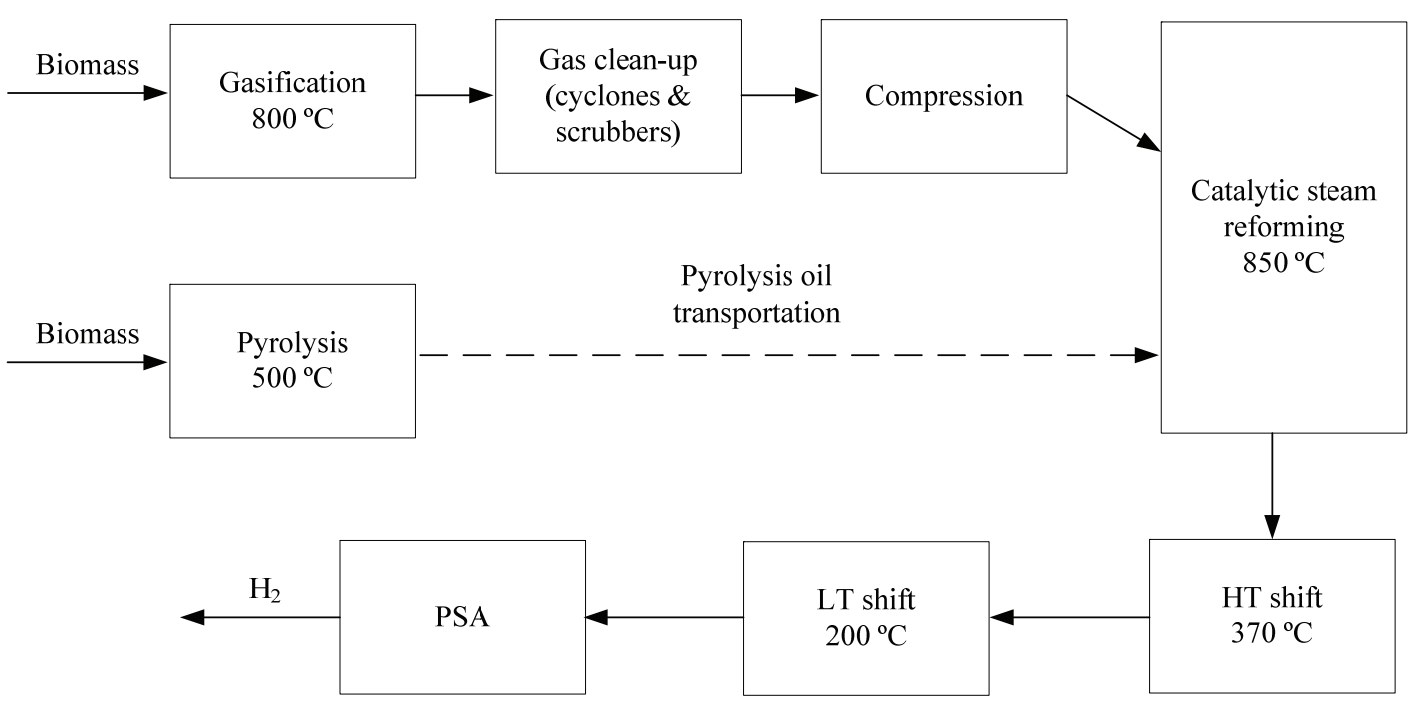

Figure 1.1: Schematic representation of a proposed route for hydrogen production from biomass [13].

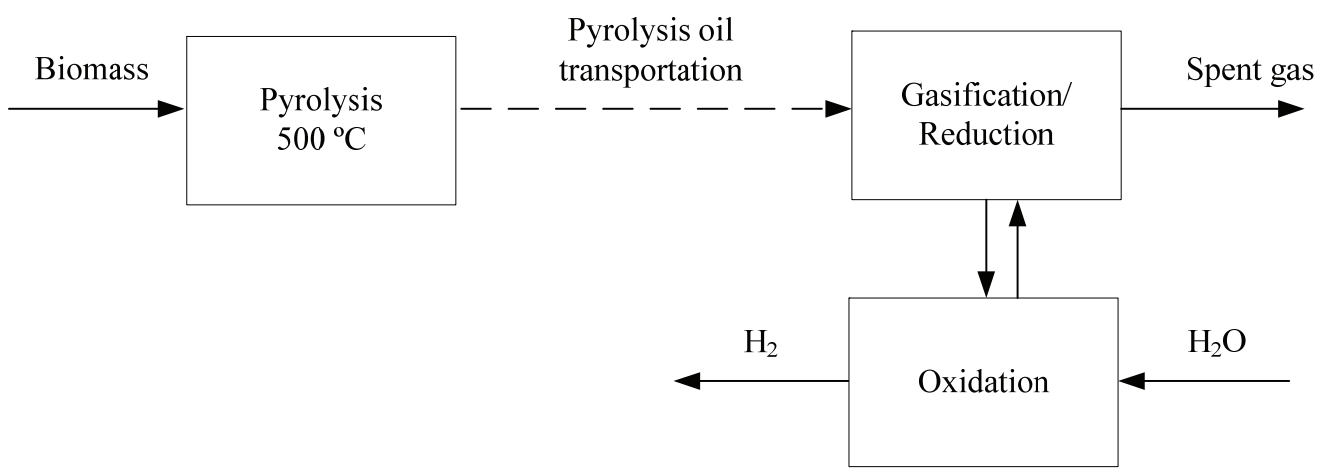

Figure 1.2: Hydrogen production from pyrolysis oil using the steam-iron process, in which gasification/reduction is taking place simultaneously.

The scope of this $\mathrm{PhD}$ thesis is to study the feasibility of the production of pure hydrogen from pyrolysis oil in the steam-iron process. The main benefit of the steam-iron process compared to conventional biomass to hydrogen processes, is that it requires none or less purification steps. In Figure 1.2 a schematic overview of the steam-iron process is shown and the two-step process replaces the catalytic reforming, 
HT shift, LT shift and the PSA. The concept uses a redox cycle of an iron oxide (Figure 1.3), in which the reduction is performed with pyrolysis oil. The reduced iron oxide is oxidized with steam in a separate step, resulting in pure hydrogen.

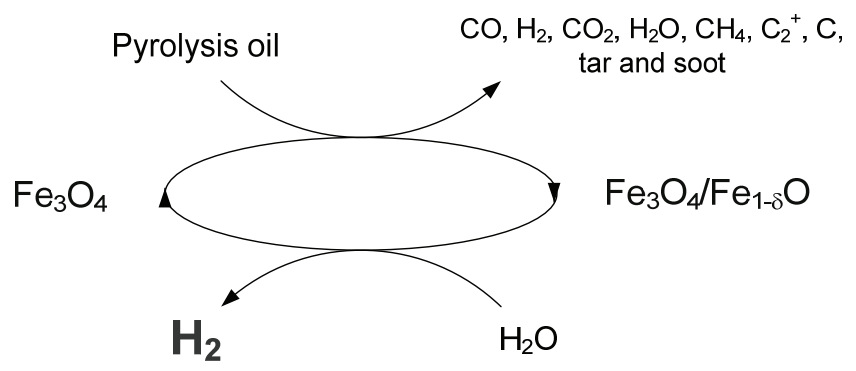

Figure 1.3: Steam-iron process with pyrolysis oil.

Although the steam-iron process (with water gas as reducing gas) was applied in the early $19^{\text {th }}$ century, it has never been able to compete with the later on developed steam reforming of methane. The challenge of this research project is therefore to apply a relatively new feedstock (pyrolysis oil) in an old concept which has not been in use for nearly a century to produce pure hydrogen.

\subsection{Outline of the thesis}

In Chapter 2 a short literature review is given in which the old steam-iron process is described as well as new research related to the steam-iron process. The chapter continues with a thermodynamic analysis of the gasification and reduction reactions with pyrolysis oil. With the information obtained a process efficiency of the hydrogen production in the steam-iron process with pyrolysis oil is calculated.

In Chapter 3 the first experimental redox cycles with pyrolysis oil are described, using both a catalytic and a non-catalytic iron oxide. Gasification of the oil and reduction of the iron oxide take place simultaneously in the fluidized bed reactor, followed by the oxidation with steam. The oil/iron oxide ratio in the reduction is varied. With these first scouting experiments parameters and phenomena, like deactivation of the iron oxide, that affect the hydrogen production in the redox cycle are observed and are subject of study in following chapters.

In Chapter 4 the effect of the temperature and the conversion of the iron oxide in the reduction on the hydrogen production in the redox cycle with oil and 
deactivated catalytic iron oxide is described. A mechanism describing the gasification of oil over an iron oxide fluidized bed is proposed, based on redox experiments in the fluidized bed and on thermo gravimetric analysis with catalytic iron oxide/oil samples.

In Chapter 5 the reduction and oxidation of the iron oxide are studied in a packed bed reactor using $\mathrm{H}_{2}$ and $\mathrm{H}_{2} \mathrm{O}$ as model compounds. Both a temperature programmed reduction and an isothermal reduction method are used to study the reduction. Known particle models are used to define the mechanism that determines the measured conversion rate.

Chapter 6 describes the deactivation of the iron oxide due to consecutive redox reactions. Redox cycles are performed in the packed bed set-up with catalytic iron oxide. A sinter model and the grainy pellet model are applied to describe the measured deactivation in the oxidation over subsequent cycles.

Finally a process design study is performed in Chapter 7 by using both theoretical and experimental data.

\subsection{Literature}

1 Ramage, P.R. and R. Agrawal, The hydrogen economy: Opportunities, costs, barriers and R\&D needs. Washington D.C., National Academies Press, 2004.

2 Huffman, J., Chemical Market Reporter 267 (2005) 18

3 Shinnar, R., Technology in Society 25 (2003) 455-476

4 Raissi, A. and D.L. Block, Hydrogen: Automotive fuel of the future. IEEE power \& energy magazine, 6 (2004) 40-45.

5 Groeneveld, M., Shell.

6 Tijmensena, M.J.A., et al., Biomass and Bioenergy, 23 (2002) 129-152.

7 Prins, M.J., Fuel Processing Technology, 86 (2004) 375-389.

8 Samaloda, M.C., W. Baldauf, and I.A. Vasalos, Fuel, 14 (1998) 1667-1675.

9 Hamelinck, C.N. and A.P.C. Faaij, Journal of Power Sources, 111 (2002)1-22.

10 Iwasaki, W., International Journal of Hydrogen Energy, 28 (2003) 939-944.

11 Bridgwater, A.V., Fast pyrolysis of biomass: a handbook Vol. 2. Newbury, CPL Press, 2002.

12 Bridgwater, A.V., Thermal sciences, 8 (2004) 21-49.

13 Spath P.L., Mann M.K., Amos W.A., NREL/MP-510-33112, National Renewable Energy Laboratory, Golden, CO., 2000. 


\title{
Chapter 2
}

\section{Review and thermodynamic study of the steam-iron process with pyrolysis oil}

\begin{abstract}
A literature study on the steam-iron process has been performed to outline previous and current applications of the process. A thermodynamic evaluation of the steam-iron process with pyrolysis oil showed that the reduction of magnetite to wustite and iron is feasible for temperatures above about $627{ }^{\circ} \mathrm{C}$. A substantial amount of solid carbon is expected during the inert gasification of oil, which can contribute in the reduction if a contact between the iron oxide and the solid carbon is established. The reduction improved and the steam conversion in the oxidation decreased when the temperature in the redox cycle is increased. Both effects result in an optimum process efficiency of $64 \%$ (LHV based) at +/- $727{ }^{\circ} \mathrm{C}$. At this temperature a hydrogen production of $1.30 \mathrm{Nm}^{3} / \mathrm{kg}$ dry oil can be achieved.
\end{abstract}




\subsection{Introduction}

The principle of the redox cycle based production of hydrogen was first used in the steam-iron process at the beginning of the 20th century. The first manufacturers were Messerschmitt and Lane [1]. In those days, gas produced by the gasification of cokes reduced iron oxides that were subsequently oxidized with steam for the production of pure hydrogen. At present the steam-iron process is not in use anymore for the production of hydrogen, because other processes economically are more efficient. However, some research activities are still ongoing towards use of "cheap" hydrocarbon feedstocks as reducing agents, improved reactor concept and metal oxide as redox material [2-7].

In this chapter, the concept of the steam-iron process and how it has developed since its first application, will be presented. Next, pyrolysis oil as feedstock for the steam-iron process will be introduced. The chapter ends with a theoretical analysis, based on the thermodynamics of the system, and a discussion on the feasibility of pyrolysis oil as a feedstock in the production of pure hydrogen based on the steamiron process.

\subsection{Literature review - steam-iron process}

The application of redox cycles for the production of pure hydrogen has had attention from the moment the concept was first discovered by Lavoisier in 1784 [8]. The concept is based on a redox cycle of a metal oxide, in which the reduction and oxidation are consecutively performed separately (Figure 2.1). In this way pure hydrogen can be obtained in the oxidation step, without the need of any purification.

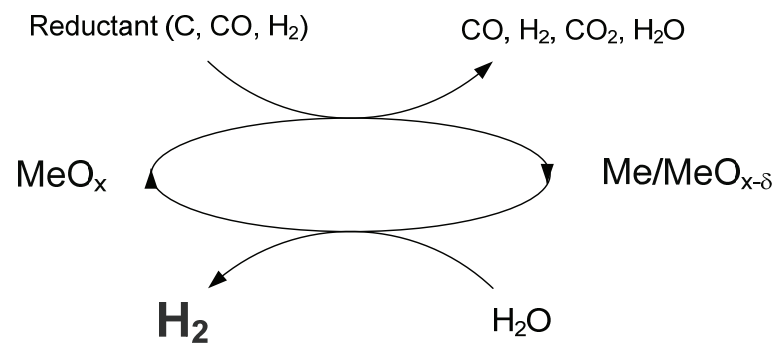

Figure 2.1: Steam-iron process representation. 
Different types of gaseous, liquid and solid feedstocks (coke, biomass, heavy oils, methane) have been used as reductant, which were initially converted to reducing gases like carbon monoxide and hydrogen. Generally any feedstock can be applied if $\mathrm{CO}, \mathrm{H}_{2}$ or $\mathrm{C}$ can be produced from it. In most cases iron oxides were used as redox material for the process, mostly due to its cheap availability [1].

\subsubsection{Historic background}

Henry Cavendish was the first to isolate and characterize hydrogen (1673), but it was Lavoisier who discovered the production of hydrogen applying a reaction between steam and iron (1784) [8]. With this reaction, Lavoisier wanted to obtain a better understanding of the composition of water. He heated small iron particles and when the iron was red-hot he passed steam over the particles. The gasses obtained were cooled and the water was condensed. A colorless gas was obtained which turned out to be highly inflammable in air, which he termed hydrogenium. From this experiment Lavoisier demonstrated that water consisted of two components namely the inflammable air $\left(\mathrm{H}_{2}\right)$ and dephlogisticated air $\left(\mathrm{O}_{2}\right)$. The iron was turned into brown-black colored solid, iron oxide. Oxygen from water had reacted with the iron and from this he concluded that mixing hydrogen and oxygen should produce water, which he also confirmed experimentally.

The interest of using hydrogen to fuel balloons started after the first one filled with hydrogen were tested by Montgolfier and Fame in 1783 [8]. After the discovery of Lavoisier to produce hydrogen using steam and iron, first attempts were made to introduce a large-scale process for hydrogen production to fuel balloons, based on this principle [8]. In the autumn of 1793 the first pilot plant designed by Coutelle and Conté produced hydrogen. The reactor consisted of a cast iron pipe of $0.9 \mathrm{~m}$ long and $0.3 \mathrm{~m}$ in diameter. The pipe was loaded with $73 \mathrm{~kg}$ of iron fragments and placed in a large furnace. This furnace was heated by burning wood (as coal supply was limited during the war) to a temperature which made the iron soft and slightly to sag. The reactor tube was connected with copper connections to an iron pipe, which was led through a cooling bath containing cold water. The product gas was collected in balloons. In this first large scale attempt $24 \mathrm{~m}^{3} \mathrm{H}_{2}$ was produced by continuously running over four days. One of the main technical problems encountered after this first experiment was the water flow. A high water flow resulted in the production of a large amount of hot product gas at the start of the process, making the solder of the connection pipes to melt. Furthermore a high flow rate led to the condensation of 
water in the balloons. A too low flow rate resulted in overheating and sagging of the reactor pipe. Another problem which occurred was the formation of carbon dioxide due to a reaction with cast iron (containing $4.5 \mathrm{wt} \%$ of carbon) used as reactor material. To obtain an adequate buoyancy of the product gas in the balloon, scrubbing with limewater was required, to remove most of the carbon dioxide. In March 1794 a 7 pipe process was successfully established by Coutelle for hydrogen production (Figure 2.2). Though, the main difficulty remained the controlling the temperature and preventing the melting of the reactor.

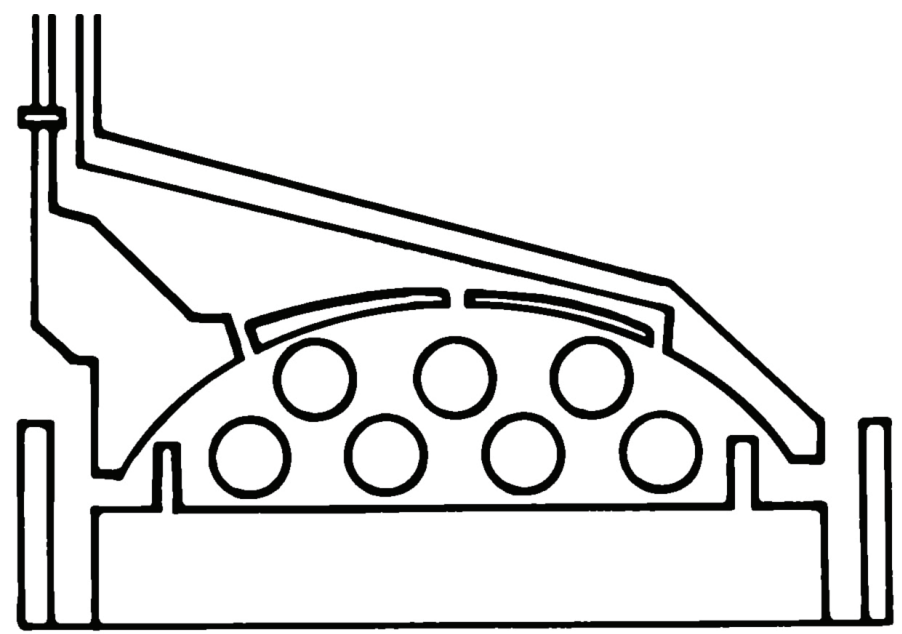

Figure 2.2: Cross-section (end-view) of hydrogen-generating furnace containing seven reactor pipes $[8]$.

During tests a balloon with a diameter of $7.9 \mathrm{~m}\left(263 \mathrm{~m}^{3}\right)$ was filled in two days. After this successful demonstration ballooning was adopted in the military for three years. Unfortunately, after three years, the use of ballooning in the military was abandoned, due to strong criticism by the government. This criticism was basically based on the slow hydrogen production, the temperature control in the process and the fact that there were no $\mathrm{H}_{2}$ storage possibilities available.

\subsubsection{Lane, Messerschmitt and Bamag process}

During the First World War, large quantities of relatively pure hydrogen out of coal were produced in Germany by the steam-iron process. This hydrogen was mainly for fuelling the zeppelin airships and later also for the production of ammonia. 
Three somewhat different processes were applied, out of which the Lane process was the first to operate commercially. In these processes water gas, obtained from the gasification of coal, was used as reducing gas and steam for the oxidation of the iron oxides. In the Lane process 36 vertical retorts were placed in a brick furnace chamber heated by gas burners arranged on each side. The retorts were arranged in 3 sections with 12 tubes each (3-3.5 meters length and $23 \mathrm{~cm}$ in diameter) [1]. The reduction was slower compared to the oxidation therefore $2 / 3$ of the tubes were used for reduction and the remaining $1 / 3$ for the oxidation. The gases obtained after reduction were reused for the heating of the iron tubes in the chambers. This was done by burning the depleted reduction gas in the furnaces after which the burned gas was used for the generation of steam.

The Lane process was later on followed by the Messerschmitt process (1913). Dr. Messerschmitt introduced a process which was lower in maintenance and investment costs, due to the elimination of multiple retorts [1, 9]. In the Messerschmitt process, the iron/magnetite reaction bed was placed between an outer and inner cylinder (Figure 2.3). The inner cylinder was heated by burning some dry water gas obtained from coal gasification to heat the iron oxides in the outer cylinder. The Messerschmitt process was later on followed up by the Bamag process. In the Bamag process the generator consisted of a steel shell lined with refractory brick with a specially designed combustion arch about $2 / 3$ of the depth of the generator above the grate. The upper chamber (above the arch) was filled with checkers which acted as a superheater for steam, when making gas. The lower chamber was the ore chamber. Connections for gas inlet and the hydrogen outlet were placed at the bottom of the lower chamber [9]. 


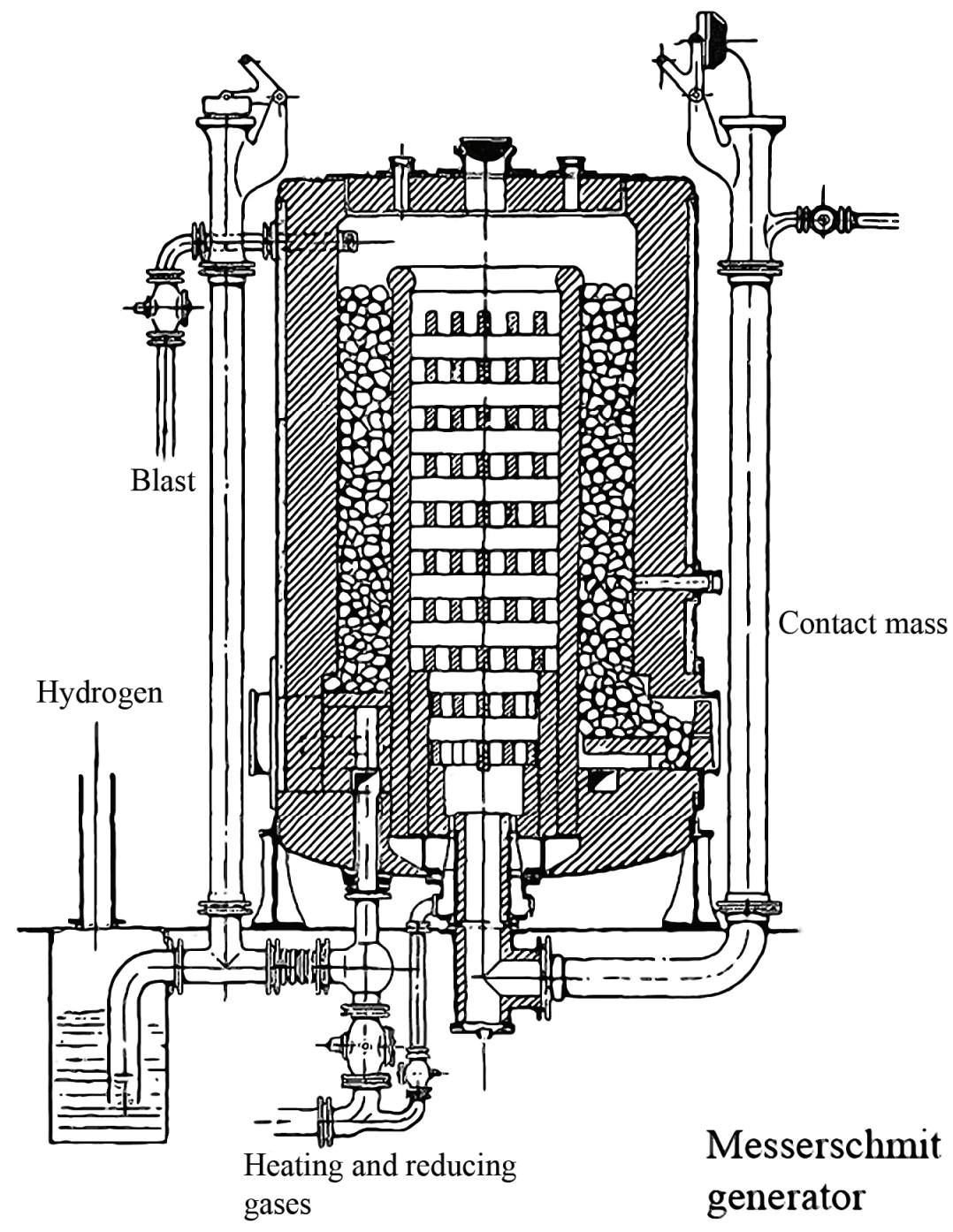




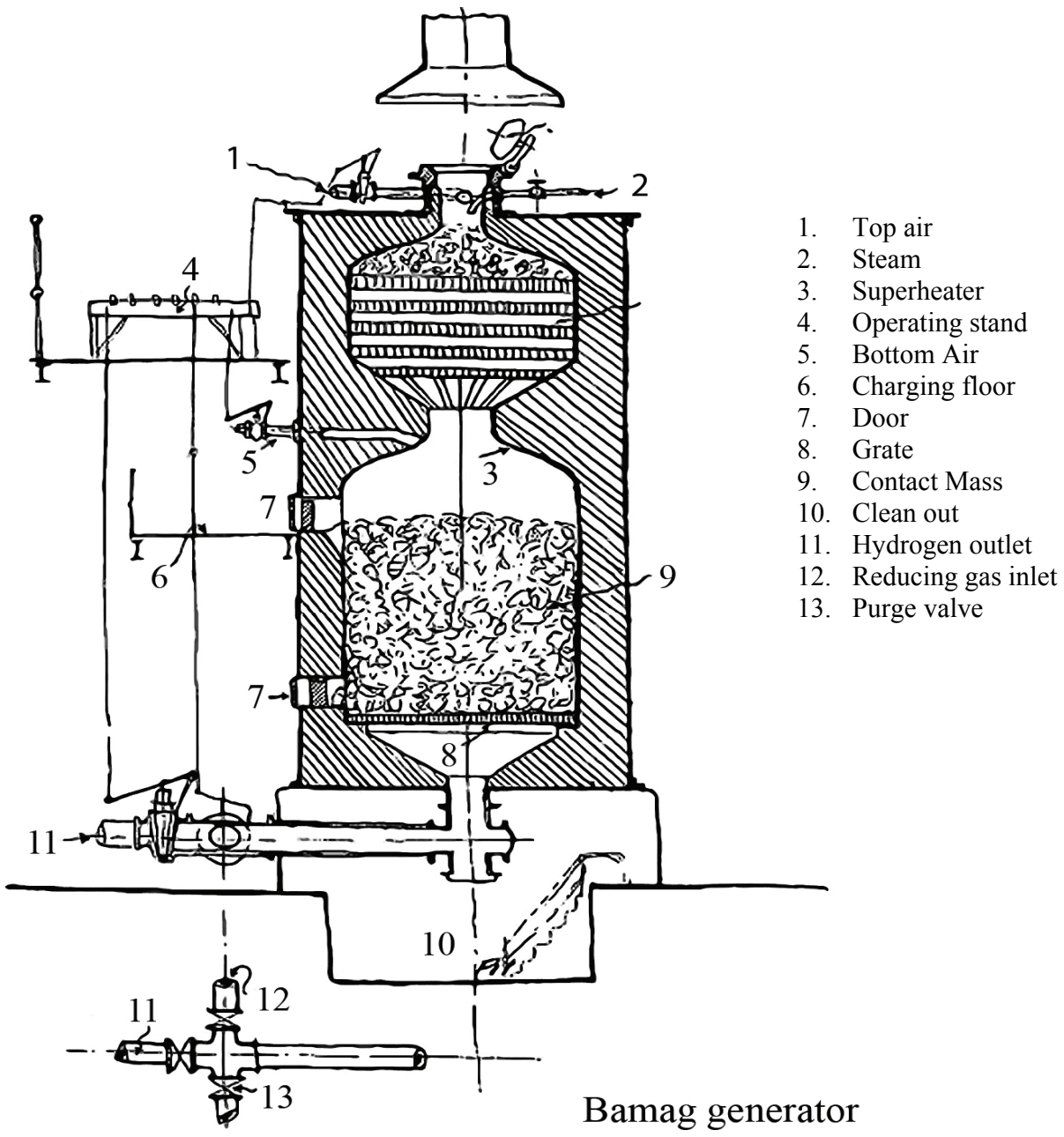

Plan of valve arrangement at bottom

Figure 2.3: Messerschmit and Bamag reactor [9].

Water gas $\left(50 \% \mathrm{H}_{2}, 40 \% \mathrm{CO}\right.$ and $\left.\mathrm{N}_{2}, \mathrm{CO}_{2}, \mathrm{CH}_{4}\right)$, obtained from the steam gasification of coal was used for the reduction of the iron oxide. In most processes the reduction gas was first cleaned from $\mathrm{H}_{2} \mathrm{~S}$ and dust before starting the reduction. However, some recommendations reported not to do this [9], as it might result in the formation of $\mathrm{FeS}$ and enhanced sintering of the pellets. The reduction temperature was between the 550 and $800{ }^{\circ} \mathrm{C}$. At the low temperature mentioned the reduction of $\mathrm{Fe}_{3} \mathrm{O}_{4}$ to $\mathrm{Fe}$ took place because $\mathrm{FeO}$ is not stable at temperatures below $570{ }^{\circ} \mathrm{C}$. The oxidation was conducted - for kinetic reasons - at temperatures between $700-900{ }^{\circ} \mathrm{C}$. During reduction carbon deposition took place when most of the iron oxide was 
reduced and $\mathrm{CO}$ was present in the gas phase. Carbon, deposited during the reduction step, was burned off with steam or air, which deteriorated the structure and reactivity of the iron oxide. Furthermore the presence of sulfur components caused an accumulation of sulfur in the iron ore. Therefore, also after oxidation, air was introduced to burn remaining carbon and sulfur components from the iron tubes. If a no burn off was applied the material would lose its redox capacity after already several redox cycles. This "burn off" was therefore essential for the repeated usage of the iron oxides in the redox reactions. The reaction of the iron oxide with oxygen is a highly exothermic reaction and therefore the temperature control during the burn off stage was difficult. A too strong increase in temperature could deteriorate the iron oxide and damage the reactor. On the average the iron tubes lasted for 6 months. But normally it was more rewarding to exchange them after 2 months [1].

During reduction the conversion obtained depended strongly on the temperature and could be in the range of $2.7 \mathrm{~m}^{3}$ water gas needed to produce $1 \mathrm{~m}^{3} \mathrm{H}_{2}$ at $570{ }^{\circ} \mathrm{C}$ and $1.33 \mathrm{~m}^{3}$ water gas at $850{ }^{\circ} \mathrm{C}$. Converting this into an energy efficiency $\left(\mathrm{H}_{2}\right.$ obtained LHV/water gas used LHV) results in an efficiency of 0.34 at $570{ }^{\circ} \mathrm{C}$ and 0.70 at $850{ }^{\circ} \mathrm{C}$ [1]. With pure steam in the oxidation step (Lane process), the conversion of steam to hydrogen dropped from $38 \%$ to $13 \%$ over subsequent cycles. It was thought that a decrease of active iron oxide caused this. Therefore Mn (around 18 wt \%) was added to the iron, resulting in a conversion of $33 \%$ (at $600{ }^{\circ} \mathrm{C}$ ) and $44.4 \%$ (at $720{ }^{\circ} \mathrm{C}$ ) after oxidation with pure steam. The Messerschmitt process yielded an average of $60,000 \mathrm{~m}^{3} \mathrm{H}_{2}$ from $3000-3500 \mathrm{~kg}$ iron, after which the iron needed to be replaced. Pyrite residues, ironstone and iron gravel were used and prepared to obtain a high surface area. Components like $\mathrm{Mn}, \mathrm{Cr}, \mathrm{Ti}, \mathrm{Cu}, \mathrm{Pb}, \mathrm{V}$ and $\mathrm{Al}$ were added to improve the reduction performance and cycle stability [1].

Because of the inefficiency of the cyclic operation and the low reaction rate resulting from the necessity of large granules of iron oxide in the fixed bed, the cost of producing hydrogen by this method is high. Following the invention of the more economical steam reforming of methane, the steam-iron process slowly fell into disuse. 


\subsection{Current research}

\subsubsection{Research at the Institute of Gas Technology, Chicago (Illinois), USA}

After the introduction of the industrial scale steam reforming of methane, the idea of using the steam-iron process for the production of hydrogen from coal (or purification) re-appeared at the end of the 1950s. It was thought that the steam iron process could be made more economic than the hydrogen production from coalgasification processes. The supposed advantage of producing hydrogen and synthesis gas by the steam-iron method lies in the elimination of investment and operating cost of an oxygen plant [10]. Later on this interest was renewed and was directed to the hydrogen production for hydrogasification of coal and the production of hydrogen for ammonia and petrochemicals manufacture. IGT worked from 1961-1971 on developing the steam-iron process for direct synthetic pipeline gas (SPG) production.

The modified steam-iron process using the $\mathrm{Fe} / \mathrm{Fe}_{3} \mathrm{O}_{4}$ cycle was developed up to pilot plant scale in 1976 for the conversion of (wet) coal gas to hydrogen. The pilot plant consisted of four fluidized beds in which a countercurrent operation was established [2, 3, 11, 12], to improve the gas-solid contact and to provide for a continuous operation. For non published programmatic reasons, the Department of Energy decided to discontinue the funding for this project and therefore all operations at the pilot plant were terminated in September 1978.

The pilot plant consisted of a high-pressure char/water slurry heater (containing 35-50 wt\% char, 20-50 bar, $315{ }^{\circ} \mathrm{C}$ ). The steam produced in the slurry heater transports the dry char to the top of the preheater. In the preheater $10 \%$ of the feed char is burned, raising the temperature from 315 to $954{ }^{\circ} \mathrm{C}$ (Figure 2.4). The preheated char then enters a gas producer bed (fluidized bed char gasifier), in which almost the entire char is gasified with steam and oxygen. The producer is operated at high temperatures $\left(954-1090{ }^{\circ} \mathrm{C}\right)$ in order to obtain a high quality reducing gas with low $(<5 \%)$ concentrations of $\mathrm{CO}_{2}$ and $\mathrm{H}_{2} \mathrm{O}$, which would otherwise inhibit the reducing ability of the gas. The hot producer gas is then led to the reducer in the fluidized-bed steam-iron reactor. The steam-iron reactor was most profitably operated at $816{ }^{\circ} \mathrm{C}$ in both the reducer and oxidizer [3]. The temperature of the steam-iron 
reactor was influenced by the inlet of hot producer gas $\left(954-1090^{\circ} \mathrm{C}\right)$ in the reduction step and the inlet of a cooler steam inlet $\left(425^{\circ} \mathrm{C}\right)$ in the oxidation step.

In the steam-iron reactor four fluidized bed were used; solids were fed at the top of the steam-iron reactor and were going down through the two step reducer and the two step oxidizer. Gasses were contacting the solids in a countercurrent mode. Both reduction and oxidation reactor consisted of two fluidized beds, which were called the lower (bottom) and upper zone. The feed of the steam-iron reactor, the producer gas, is fed at the bottom of the reducer reactor where wustite $\left(\mathrm{Fe}_{1-\delta} \mathrm{O}\right)$ is converted into iron $(\mathrm{Fe})$. The heat of the producer gas was used for the endothermic reduction reactions. Because of this heat and the high reducing capacity of the gas, wustite is converted to iron. In this part (the bottom) $20 \%$ of the reducer gas is converted. In the upper stage of the reduction reactor, magnetite is converted to wustite. Here the major and final conversion of the reducing gas takes place and a total conversion of the producer gas of $65 \%$ is obtained. Steam is fed to the lower part of the oxidizer to convert wustite into magnetite; a conversion of around $30 \%$ (equilibrium limit of the oxidation of $\mathrm{Fe}_{1-\delta} \mathrm{O}$ to $\mathrm{Fe}_{3} \mathrm{O}_{4}$ at $+/-800{ }^{\circ} \mathrm{C}$ ) of the feed steam can be obtained in this stage. In the upper part of the oxidizer iron is converted into wustite and a maximum of $66 \%$ of total steam to hydrogen conversion (equilibrium limit of the oxidation of $\mathrm{Fe}$ to $\mathrm{Fe}_{1-\delta} \mathrm{O}$ ) can be obtained in this stage at $816{ }^{\circ} \mathrm{C}$. The total conversion of steam to hydrogen was set to a conversion of $45 \%$ by controlling the amount of iron formed in the reduction step. It was not necessary to obtain a higher steam conversion, because a gas with 55-60\% of steam was needed for the thermal and kinetic balance in the hydrogasifier, in which coal was gasified with the product gas to SPG (synthetic pipeline gas). The iron oxides applied were a sintered siderite $\left(\mathrm{FeCO}_{3}\right)$. Ore was circulated (6-71 tons/h) by a lift, which moved the solids from the bottom to the top of the steam-iron reactor. Circulation was maintained with steam in the lower part of the dense-phase lift and by a pressure difference between the used producer gas and the producer gas itself in the upper part of the dense-phase lift. 


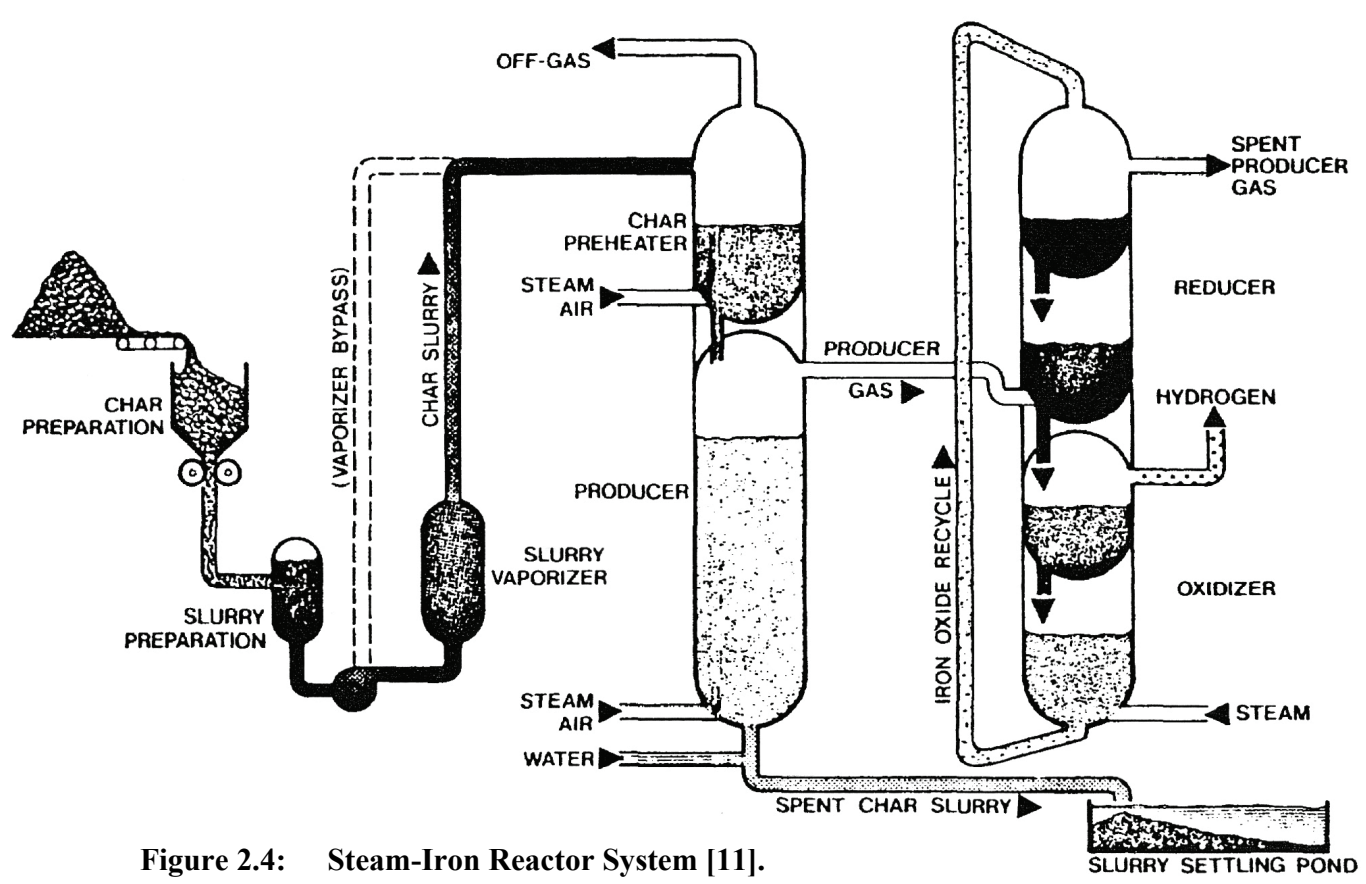

The most successful run in the pilot plant was for 5 days at a producer reactor temperature between 870 and $980{ }^{\circ} \mathrm{C}$ and a steam-iron reactor at $540{ }^{\circ} \mathrm{C}$ at a pressure of around 24 bars. The hydrogen production at these low temperatures was 80-130 $\mathrm{Nm}^{3} / \mathrm{h}$ and the total amount of char used was 185 tons [11]. This would result in a hydrogen production of $0.1 \mathrm{Nm}^{3} / \mathrm{kg}$ char. This low char to hydrogen conversion is probably due to the low temperature in both producer and steam-iron reactor in this run. Successful runs on higher temperatures are reported, but the hydrogen production was not given in the reference [11]. Probably the time, in which test were performed with the steam-iron reactor, was too short (April to September 1978) to obtain representable data.

The hydrogen production rate in relation with the iron ore circulation rate is $0.13 \mathrm{Nm}^{3} \mathrm{H}_{2} / \mathrm{kg}$ iron ore. In this case, the only clean-up necessary to obtain $99 \%$ pure hydrogen gas was sulfur removal and methanation to remove small concentrations of carbon monoxide. In addition the spent reducing gasses contain useable energy.

\subsubsection{Research at the University of Technology, Graz, Austria}

The Sponge Iron Reaction (SIR) was investigated at the University of Technology, Graz. Sponge iron is the product formed when iron ore is reduced to metallic iron at temperatures below the melting point of iron. This results in a spongy 
mass, sometimes called a bloom, consisting of a mix of incandescent wrought iron and slag [13].

Iron ore pellets were contacted with a synthesis gas for reduction and the oxidation was carried out with steam for the production of hydrogen. The hydrogen produced is used in SO/PEM fuel cells and therefore needs to be sufficiently pure. The process is conducted in a fixed bed mode. The presence of $\mathrm{CO}_{2}$ and $\mathrm{H}_{2} \mathrm{O}$ in the biomass gas lowers the reducing potential of the gas. Furthermore when biomass gas (low partial pressure of $\mathrm{CO}$ and $\mathrm{H}_{2}$ ) is used, a redox reaction takes place between magnetite and wustite. Therefore, to increase efficiencies a reformer was installed before the SIR process in which hydrocarbons were converted to a synthesis gas [6]. This unit was called the RESC (Reformer Sponge iron Cycle, Figure 2.5). The reformer is operated at a temperature between 800 and $850{ }^{\circ} \mathrm{C}$. The SIR process replaces both shift conversion and final purification.

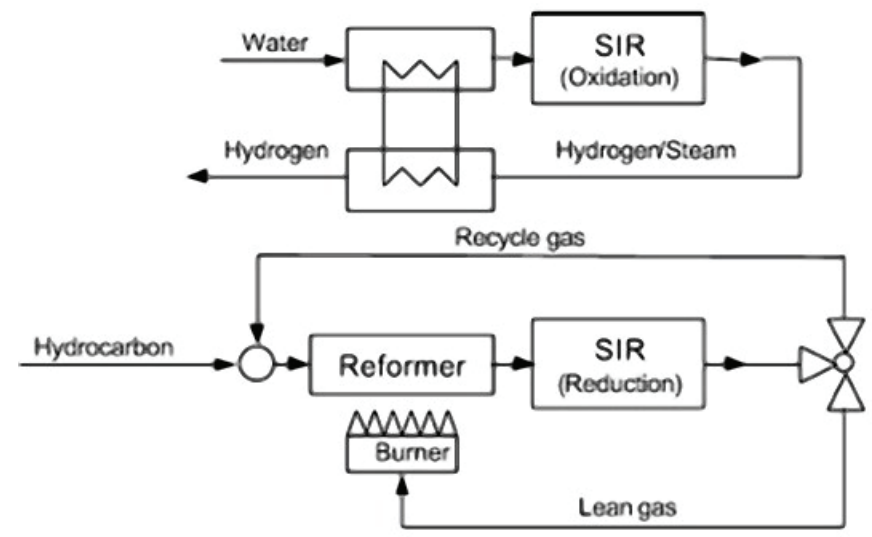

Figure 2.5: Concept of the reformer sponge iron cycle (RESC) in oxidation mode (above) and reduction mode (below) [13].

A thermal efficiency of $45 \%$ (LHV hydrogen/LHV biomass gas $100 \%$ ) was calculated with synthesis gases from biomass [14]. Process efficiencies for hydrocarbon sources like methane, heptane and octane were in the order of $75 \%$ (based on LHV) [15]. Experiments in the SIR process [7] showed that a high temperature favored hydrogen productivity. A better reduction of the iron oxides is expected with increasing temperatures from the thermodynamic and kinetic points of view. Hacker found that similar $\mathrm{H}_{2} / \mathrm{H}_{2} \mathrm{O}$ yields were obtained in the oxidation at high 
temperatures as at low temperatures. This might be due to the kinetically limited oxidation at lower temperatures, although it is thermodynamically favored at low temperatures.

\subsubsection{Research at the Paul Scherrer Institut, Villigen, Switzerland}

A redox system for producing hydrogen from woody biomass was investigated at this institute between 2000 and 2003 [6, 7, 14]. The objective of the work was to maximize the conversion of fuel gas to hydrogen. Experiments were carried out in a fixed bed reactor at a temperature of around $800{ }^{\circ} \mathrm{C}$. Iron oxide pellets were made from $\mathrm{Fe}_{3} \mathrm{O}_{4}$ powder using $10 \% \mathrm{CaCO}_{3}$ as a binder. In the reduction stage, fuel gas was mixed with steam and in the oxidation stage nitrogen and steam were mixed. No carbon deposition took place on the bed material.

Results showed that the hydrogen efficiency was dependent on the $\left(\mathrm{CO}_{2}+\mathrm{H}_{2} \mathrm{O}\right) /\left(\mathrm{CO}+\mathrm{H}_{2}\right)$ molar ratio $(\mathrm{O} / \mathrm{F}$ ratio $)$ of the fuel gas. The presence of $\mathrm{H}_{2} \mathrm{O}$ and $\mathrm{CO}_{2}$ in the biomass gas has a negative influence on the reducing potential of the gas and thus on the hydrogen efficiency. The initial ratio is determined by the gasifier and the biomass feedstock. From experiments with $\mathrm{CO} / \mathrm{CO}_{2}$ mixtures it was found that an equilibrium composition of $\mathrm{CO} / \mathrm{CO}_{2}$ with the magnetite/wustite was obtained. Therefore, to improve the degree of reduction of the iron oxide, the reducing potential of the fuel gas needs to be optimized by reducing the amount of $\mathrm{CO}_{2}$ and $\mathrm{H}_{2} \mathrm{O}$ in the fuel gas. The methane in the fuel gas was mostly unused (>95\%), causing a low efficiency.

The final $\mathrm{O} / \mathrm{F}$ ratio was determined by the thermo-chemical properties of the metal oxide material. This final $\mathrm{O} / \mathrm{F}$ ratio in the reduction step can be improved by changing the material, but this will have a negative influence on the reverse reaction (oxidation); less steam will be converted to hydrogen. A trade-off needs to be found between the heat loss for the production of steam and the fuel losses in the incomplete conversion of the raw gas. Modeling predicted that - under ideal conditions - an overall biomass to pure hydrogen energy efficiency of $45 \%$ (based on LHV) should be achievable [14].

A cost calculation was performed for a process involving two fluidized beds. An energy density of $0.35 \mathrm{MW}_{\mathrm{th}} / \mathrm{m}^{3}$ (total thermal power in the fuel gas/total volume of the redox beds), reported by Hacker [7], was used in these calculations. Sime et.al. [16] concluded that PSA technology was $60 \%$ cheaper than the steam-iron process. In the steam-iron process the capital costs are much higher because of the low energy 
density in the steam-iron reactor bed. They concluded that the feasibility of the steamiron process depends on the improvement of the energy density of the bed (fuel/iron oxide ratio) by a better materials selection.

\subsubsection{Research at the Technical Research Center, Saitama, Japan}

Suzuka et. al. [4] used the combination of the steam-iron process and residual oil cracking. Iron oxide was found to be an effective catalyst for the steam gasification of oil with simultaneous generation of hydrogen. The hydrogen produced can be used to hydro-treat the distillates produced by the cracking process and thereby improve their quality. The process consists of a cracker and a regenerator (Figure 2.6). The cracker consists of a steam oxidation zone (lower zone) and a cracking zone (upper zone), which are separated by a distributor plate. In the steam oxidation zone of the cracker the hydrogen is produced from the reaction of wustite with $\mathrm{H}_{2} \mathrm{O}$, converting the wustite into magnetite. In the post cracking zone the residual oil is cracked over the formed magnetite catalyst, resulting in the formation of cokes on the catalyst. In the regenerator, the coke deposited on the magnetite catalyst is partially oxidized by air, and the magnetite is reduced to wustite. In the desulfurizer, the sulfur in the catalyst is removed by roasting the catalyst with air.

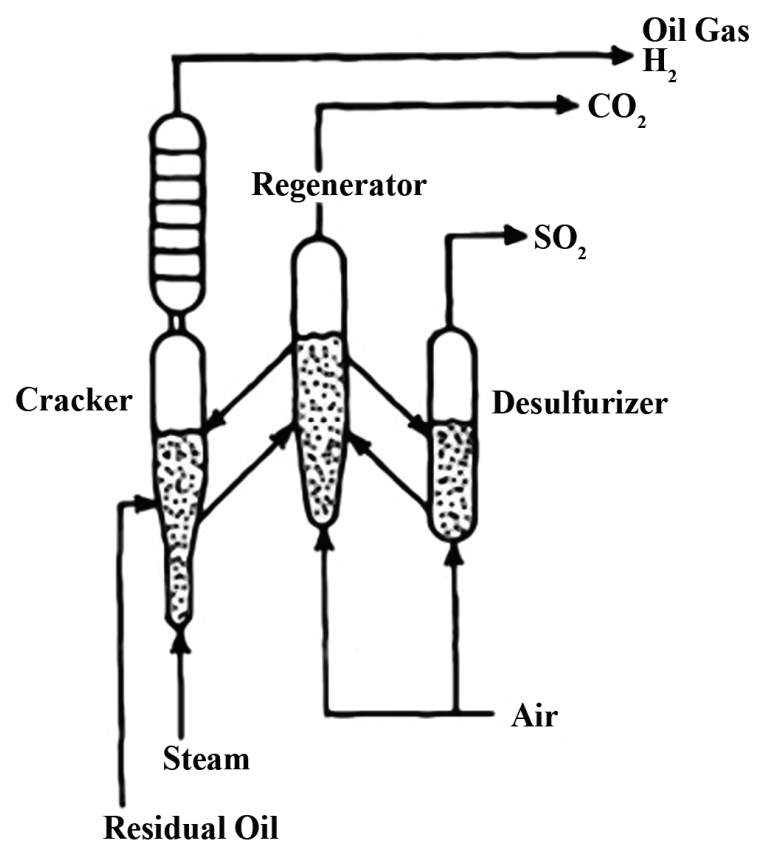

Figure 2.6: Flow diagram of the residual oil cracking process [4]. 
From experimental results [17] it was found that the extent of the reduction of the iron oxide increased with the increase of the coke on the iron oxide. The partial oxidation of the coke on the iron oxide is used to supply heat for the cracking reaction. Therefore a mixture of $\mathrm{N}_{2}$ and air is used as fluidizing gas in the pilot plant. From experiments with the pilot plant it was found that $301 \mathrm{H}_{2} / \mathrm{kg}$ oil was generated from dehydrogenation of the feed oil. The amount of hydrogen produced with the steamiron process combined with dehydrogenation of the feed oil was $2101 \mathrm{H}_{2} / \mathrm{kg}$ oil (69 vol $\%$ of product gas).

Suzuka et.al. $[4,5]$ continued their research on the addition of foreign oxides on the reducibility/oxidizability and stability of the iron oxide. Several iron oxides were tested, namely a natural iron ore (laterite, a hydrated ferrite), iron dust particles from the steel making process $\left(\alpha-\mathrm{Fe}\right.$ and $\left.\mathrm{Fe}_{3} \mathrm{O}_{4}\right)$ and a commercial iron oxide catalyst (CO shift catalyst).

\subsubsection{Research at the Tokyo Institute of Technology, Tokyo, Japan}

Otsuka et. al. started with experimental work on the steam-iron process in the eighties using cheap reductants like carbon and biomass. They used $\operatorname{In}_{2} \mathrm{O}_{3}$ and $\mathrm{K}_{2} \mathrm{CO}_{3}$ as active oxides and mixed this with grounded carbon sources like biomass. Volatile materials formed during pyrolysis of the biomass could not reduce $\operatorname{In}_{2} \mathrm{O}_{3}$ at temperatures of about $300{ }^{\circ} \mathrm{C}$. They found that high yields of hydrogen from the biomass sources were obtained at temperatures of $500{ }^{\circ} \mathrm{C}$ and showed that chars formed by the decomposition of biomass contributed to the reduction of the metal oxide. Deactivation of the metal oxides occurred rapidly (after 3 cycles).

Many different metal oxides were tested by Otsuka et.al. [18] in combination with carbon as previously described. The most effective metal oxides found were $\mathrm{In}_{2} \mathrm{O}_{3}>\mathrm{SnO}_{2}>\mathrm{MoO}_{3}, \mathrm{Fe}_{2} \mathrm{O}_{3}$ and $\mathrm{CeO}_{2}$.

Further investigations by Otsuka et.al. [19] were focused on the storage of hydrogen in metal oxides. This technology was suggested to be used as a hydrogen storage technology in cars and is based on the steam iron process [20, 21]. The hydrogen is obtained by oxidizing a reduced metal oxide, like iron oxides and indium oxides. The metal oxide is reduced by the gasses obtained from the reforming of methane over a Ni catalyst. Direct reduction with methane would take place in large facilities and the iron stacks can then be used in cars to produce hydrogen. The technological challenge of this idea is to establish oxidation in the car at low temperatures $\left(300{ }^{\circ} \mathrm{C}\right)$. Therefore additives were investigated which can improve the 
redox of the iron oxide and keep a good cycle stability. Additives like al, $\mathrm{Cr}, \mathrm{Zr}, \mathrm{Ga}$ and $\mathrm{V}$ had a positive influence on the redox behavior of the iron oxides probably because the hydrogen is activated by the additives or by the enhancement of the diffusion of oxygen in the iron(oxides). Also sintering was less when additives were used, improving cycle stability.

\subsubsection{Research at the University Erlangen-Nurnberg, Erlangen, Germany}

Seiler [22] used the reduction-oxidation cycle in a fixed bed reactor with periodical flow reversal and investigated this reactor concept. Research was mainly focused on modeling the reverse-flow concept of the process.

\subsection{Thermodynamic evaluation of the steam-iron process using pyrolysis oil}

A thermodynamic calculation is done to find the theoretical efficiency of the production of pure hydrogen from pyrolysis oil in a redox cycle with iron oxide. This theoretical efficiency is based on the equilibrium conversion of oil and steam in the redox cycle. Therefore firstly the reduction reactions of iron oxide with carbon monoxide, carbon and hydrogen will be described. Secondly the use of pyrolysis oil as a reductant will be discussed and finally this data will be used to evaluate the overall energy efficiency of the process. The calculations in this paragraph are all based on thermodynamic data available in the Nist-Janaf tables [23].

\subsubsection{Reduction reactions}

There are different forms of iron oxide, resulting in different reduction and oxidation reactions between the oxidation states of iron oxide. The most oxidized form is hematite $\left(\mathrm{Fe}_{2} \mathrm{O}_{3}\right)$ and the most reduced form is metal iron ( $\left.\mathrm{Fe}\right)$. In between these two forms magnetite $\left(\mathrm{Fe}_{3} \mathrm{O}_{4}\right)$ and wustite $\left(\mathrm{Fe}_{(1-\delta)} \mathrm{O}\right)$ exist. In many process applications carbon is used as a feedstock for the reduction of iron oxide, e.g. in blast furnaces. The reduction with solid carbon is thermodynamically possible, however the contact between the two phases (iron and carbon) needs to be established to enable the reaction. Therefore solid carbon cannot reduce solid iron oxide, but can be used as a direct reductant when the iron oxide is in the liquid phase $\left(\mathrm{T}>1400{ }^{\circ} \mathrm{C}\right.$ ) [13] (or smelting reduction). Another option is to deposit solid carbon on the iron oxide to 
establish a contact between the carbon and the iron oxide phase. In this case reduction with carbon can take place and will be described in the following paragraphs.

\section{Reduction of hematite to magnetite}

The reduction of hematite to magnetite (Table 2.1) with $\mathrm{C}, \mathrm{CO}$ or $\mathrm{H}_{2}$ is a reaction with a $\Delta \mathrm{G}_{\mathrm{r}}<<0$ for all temperatures above $550{ }^{\circ} \mathrm{C}$ (Figure 2.7). Therefore, although the reaction is noted here as a reversible reaction, this will in practice not be the case for the temperatures applied in the steam-iron process. It can therefore be concluded that the formation of $\mathrm{Fe}_{2} \mathrm{O}_{3}$ in the steam-iron process during oxidation is impossible.

Table 2.1: Reduction of hematite to wustite.

\begin{tabular}{lllll}
\hline$\#$ & Reduction reactions & & & $\begin{array}{l}\Delta \mathrm{H}_{\mathrm{r}} \\
(\mathrm{kJ} / \mathrm{mole})\end{array}$ \\
\hline 1 & $3 \mathrm{Fe}_{2} \mathrm{O}_{3}(\mathrm{~s})+\mathrm{CO}$ & $\leftrightarrow$ & $2 \mathrm{Fe}_{3} \mathrm{O}_{4}(\mathrm{~s})+\mathrm{CO}_{2}$ & -15 \\
2 & $3 \mathrm{Fe}_{2} \mathrm{O}_{3}(\mathrm{~s})+\mathrm{H}_{2}$ & $\leftrightarrow$ & $2 \mathrm{Fe}_{3} \mathrm{O}_{4}(\mathrm{~s})+\mathrm{H}_{2} \mathrm{O}$ & -5 \\
3 & $3 \mathrm{Fe}_{2} \mathrm{O}_{3}(\mathrm{~s})+\mathrm{C}$ & $\leftrightarrow$ & $2 \mathrm{Fe}_{3} \mathrm{O}_{4}(\mathrm{~s})+\mathrm{CO}$ & 45 \\
\hline
\end{tabular}

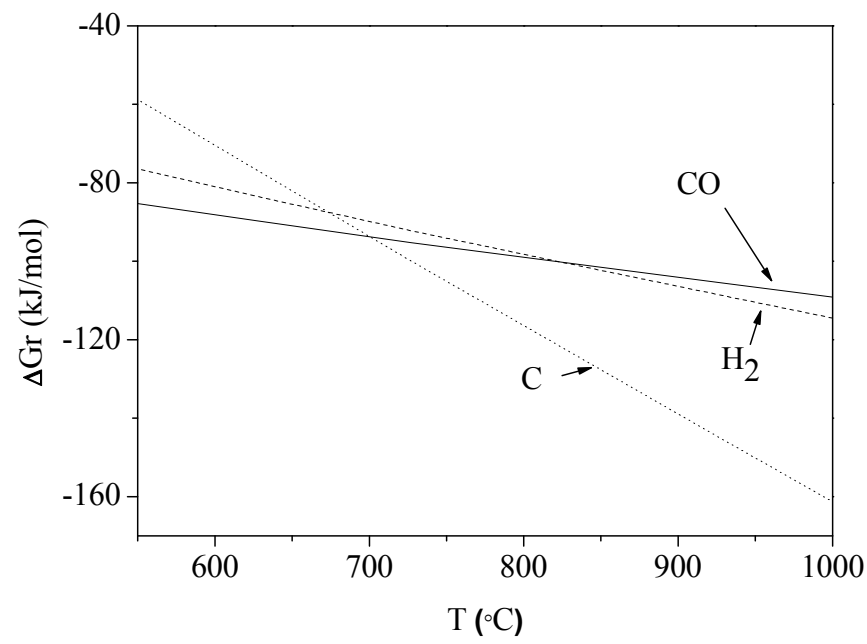

Figure 2.7: The reaction Gibbs energy for the reduction of hematite to magnetite with $\mathrm{CO}, \mathrm{H}_{2}$ and $\mathrm{C}$. 


\section{Reduction of magnetite to wustite}

Different $\mathrm{Fe} / \mathrm{O}$ ratios for wustite are given in the literature. Because wustite is cation deficient, some divalent iron is replaced by trivalent iron and vacancies. The formula of wustite can therefore differentiate and is normally denoted by $\mathrm{Fe}_{1-\delta} \mathrm{O}$ (with $0.05<\delta<0.17$ ). Wustite can contain between $23.1-25.6 \mathrm{wt} \%$ of oxygen whereas stoichiometric $\mathrm{FeO}$ would contain about 22.3 wt \% of oxygen. In the NIST JANAF tables the wustite structures of $\mathrm{Fe}_{0.945} \mathrm{O}$ is given and is therefore used in the thermodynamic calculations. The reduction reactions are shown in Table 2.2.

Table 2.2:

Reduction of magnetite to wustite.

\begin{tabular}{lllll}
\hline$\#$ & Reduction reactions & & & $\begin{array}{l}\Delta \mathrm{H}_{\mathrm{r}} \\
(\mathrm{kJ} / \mathrm{mole})\end{array}$ \\
\hline 4 & $1.2 \mathrm{Fe}_{3} \mathrm{O}_{4}(\mathrm{~s})+\mathrm{CO}$ & $\leftrightarrow$ & $3.8 \mathrm{Fe}_{0.945} \mathrm{O}(\mathrm{s})+\mathrm{CO}_{2}$ & 20 \\
5 & $1.2 \mathrm{Fe}_{3} \mathrm{O}_{4}(\mathrm{~s})+\mathrm{H}_{2}$ & $\leftrightarrow$ & $3.8 \mathrm{Fe}_{0.945} \mathrm{O}(\mathrm{s})+\mathrm{H}_{2} \mathrm{O}$ & 60 \\
6 & $1.2 \mathrm{Fe}_{3} \mathrm{O}_{4}(\mathrm{~s})+\mathrm{C}(\mathrm{s})$ & $\leftrightarrow$ & $3.8 \mathrm{Fe}_{0.945} \mathrm{O}(\mathrm{s})+\mathrm{CO}$ & 190 \\
\hline
\end{tabular}

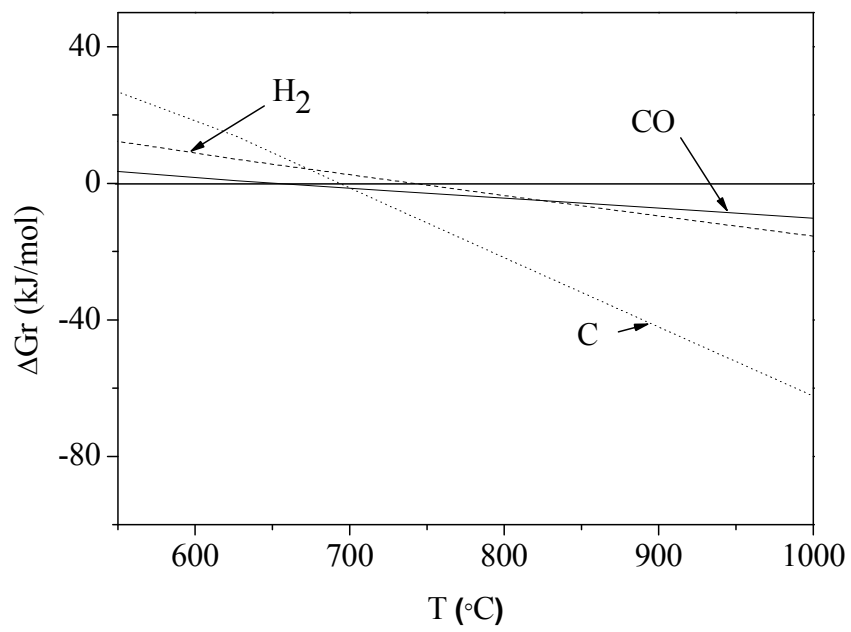

Figure 2.8: The reaction Gibbs energy for the reduction of magnetite to wustite with $\mathrm{CO}, \mathrm{H}_{2}$ and $\mathrm{C}$.

Figure 2.8 shows the reaction Gibbs energy for the reduction of magnetite to wustite for temperatures above $570{ }^{\circ} \mathrm{C}$. Below this temperature $\mathrm{Fe}_{0.945} \mathrm{O}$ is thermodynamically unstable [13]. 


\section{Reduction of wustite to iron}

The formation of metal iron takes place when a strong reducing gas is used [24] or when carbon deposits on the surface. The formation of metal iron is favorable for a high steam to hydrogen yield during the oxidation and therefore also less iron oxide is required per mole of hydrogen produced. However elementary iron can act as a catalyst in the Boudouard reaction, resulting in an increased carbon formation during reduction [13]. Furthermore the formation of iron will result in a deactivation of the iron oxide due to a decrease of the available surface area over subsequent redox cycles [5]. The reduction of wustite is shown in Table 2.3 and the reaction Gibbs energy for the reduction is given in Figure 2.9.

Table 2.3:

Reduction of wustite to iron.

\begin{tabular}{lllll}
\hline$\#$ & Reduction reactions & & & $\begin{array}{l}\Delta \mathrm{H}_{\mathrm{r}} \\
(\mathrm{kJ} / \text { mole })\end{array}$ \\
\hline 7 & $\mathrm{Fe}_{0.945} \mathrm{O}(\mathrm{s})+\mathrm{CO}$ & $\leftrightarrow$ & $0.945 \mathrm{Fe}(\mathrm{s})+\mathrm{CO}_{2}$ & -20 \\
8 & $\mathrm{Fe}_{0.945} \mathrm{O}(\mathrm{s})+\mathrm{H}_{2}$ & $\leftrightarrow$ & $0.945 \mathrm{Fe}(\mathrm{s})+\mathrm{H}_{2} \mathrm{O}$ & 18 \\
9 & $\mathrm{Fe}_{0.945} \mathrm{O}(\mathrm{s})+\mathrm{C}$ & $\leftrightarrow$ & $0.945 \mathrm{Fe}(\mathrm{s})+\mathrm{CO}$ & 150 \\
\hline
\end{tabular}

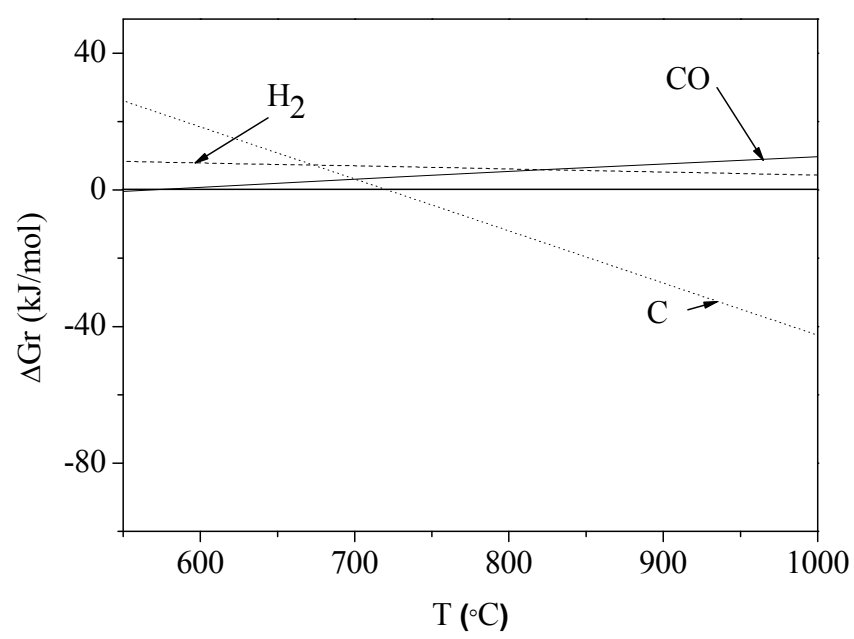

Figure 2.9: The reaction Gibbs energy for the reduction of wustite to iron with $\mathrm{CO}, \mathrm{H}_{2}$ and $\mathbf{C}$. 


\subsubsection{Thermodynamic system $\mathrm{Fe}_{3} \mathrm{O}_{4}-\mathrm{Fe}_{0.945} \mathrm{O}-\mathrm{Fe}$ with $\mathrm{CO}, \mathrm{CO}_{2}, \mathrm{H}_{2} \mathrm{O}$ and $\mathrm{H}_{2}$}

The individual reactions $(1,2,4,5,7,8$,$) are all gas solid reactions and for al$ these reactions an equilibrium constant can be defined as:

$\mathrm{K}_{\mathrm{H}}=\frac{\mathrm{P}_{\mathrm{H}_{2} \mathrm{O}}}{\mathrm{P}_{\mathrm{H}_{2}}}$ and $\mathrm{K}_{\mathrm{C}}=\frac{\mathrm{P}_{\mathrm{CO}_{2}}}{\mathrm{P}_{\mathrm{CO}}}$

The thermodynamic equilibrium constant for different temperatures can be calculated by using the reaction Gibbs energy (calculated for different temperatures), with the following relation:

$\mathrm{RT} \ln \mathrm{K}=-\Delta \mathrm{G}_{\mathrm{r}}$

The $\Delta \mathrm{G}_{\mathrm{r}}$ from Figure 2.7, 2.8 and 2.9 is used to calculate the equilibrium constant, $\mathrm{K}_{\mathrm{H}}$ and $\mathrm{K}_{\mathrm{C}}$, from which the $\mathrm{H}_{2} / \mathrm{H}_{2} \mathrm{O}$ and $\mathrm{CO} / \mathrm{CO}_{2}$ ratio at equilibrium can be derived by using equation 1.1 and 1.2. It is assumed that for each reaction the total pressure of gaseous reactants and products is equal to 1 bar. Combining this data for the individual reactions results in the, so called, Bauer-Glaessner diagram (Figure 2.10).

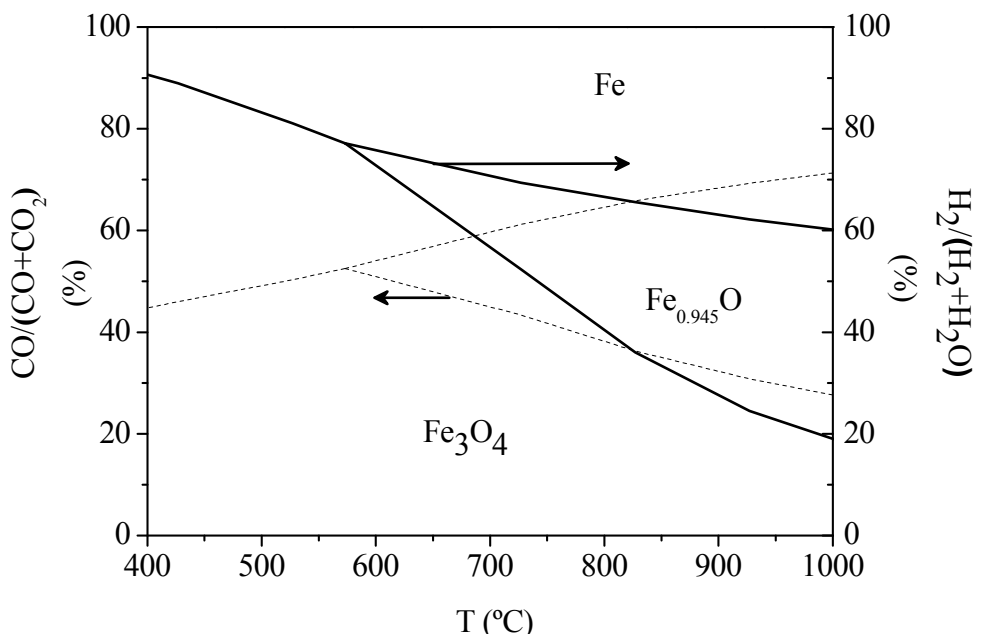

Figure 2.10: Equilibrium composition of the gas phase with a $\mathrm{CO} / \mathrm{CO}_{2}$ or $\mathrm{H}_{2} / \mathrm{H}_{2} \mathrm{O}$ mixture and $\mathrm{Fe}_{3} \mathrm{O}_{4}-\mathrm{Fe}_{0.945} \mathrm{O}$ - Fe. Calculated with thermodynamic data from NIST/JANAF [23]. 
From these thermodynamic calculations it can be concluded that wustite is only stable at temperatures above $573{ }^{\circ} \mathrm{C}$. Below this temperature magnetite can only be reduced to iron, without the formation of the intermediate wustite. Figure 2.10 shows that the reduction of the iron oxides $\left(\mathrm{Fe}_{3} \mathrm{O}_{4}, \mathrm{Fe}_{0.945} \mathrm{O}\right.$ and $\left.\mathrm{Fe}\right)$ can only take place above specific $\mathrm{H}_{2} / \mathrm{H}_{2} \mathrm{O}$ or $\mathrm{CO} / \mathrm{CO}_{2}$ ratios, which vary with temperature. Pure $\mathrm{H}_{2}$ and $\mathrm{CO}$ will lead to a reduction to iron at all temperatures as shown in the figure. However, this is not the case when a mixture of $\mathrm{H}_{2}$ and $\mathrm{H}_{2} \mathrm{O}$ or $\mathrm{CO}$ and $\mathrm{CO}_{2}$ is used. For example, a $\mathrm{H}_{2} / \mathrm{H}_{2} \mathrm{O}$ gas mixture with 40 vol $\%$ of $\mathrm{H}_{2}$ will not reduce $\mathrm{Fe}_{3} \mathrm{O}_{4}$ to iron. This specific gas mixture is only able to reduce $\mathrm{Fe}_{3} \mathrm{O}_{4}$ to $\mathrm{Fe}_{0.945} \mathrm{O}$ at temperatures above $+/-800{ }^{\circ} \mathrm{C}$. Therefore, from a thermodynamic point of view, the presence of $\mathrm{CO}_{2}$ and $\mathrm{H}_{2} \mathrm{O}$ in the reduction gas limits the operating range for the temperature at which a specific reduction reaction can take place.

The exothermic oxidation reactions with steam are the reverse reactions of the reactions 5 and 8 . The oxidation is favored thermodynamically at low temperatures (Figure 2.10). More steam can be converted when a lower temperature is applied in the oxidation. For example $60 \%$ of steam can be converted if $\mathrm{Fe}_{0.945} \mathrm{O}$ is oxidized to $\mathrm{Fe}_{3} \mathrm{O}_{4}$ at $700{ }^{\circ} \mathrm{C}$, while for the same reaction at $900{ }^{\circ} \mathrm{C}$ a steam conversion of $30 \%$ is expected.

\subsubsection{Gasification of pyrolysis oil}

When pyrolysis oil is gasified it will decompose into gaseous, liquid (at ambient conditions) and solid products. With increasing temperature more gaseous products can be expected at the expense of the solid and liquid products.

Oil $\stackrel{\text { energy }}{\longrightarrow} \mathrm{CO}+\mathrm{CO}_{2}+\mathrm{H}_{2} \mathrm{O}+\mathrm{H}_{2}+\mathrm{CH}_{4}+\mathrm{C}_{\mathrm{x}} \mathrm{H}_{\mathrm{y}}+$ tar + char

Complex organic components can be formed during gasification like tar and char. Tars [25] can be classified in three groups; the primary tars containing oxygenated hydrocarbons formed at temperatures of $400-700{ }^{\circ} \mathrm{C}$. These tars are already present in the pyrolysis oil itself (pyrolysis oil is produced at a temperature +/$500{ }^{\circ} \mathrm{C}$ ). Secondary tars consist of phenols and olefins and are formed at temperatures of $700-850{ }^{\circ} \mathrm{C}$. Finally the tertiary tars, mainly aromatic compounds formed at temperatures above $850{ }^{\circ} \mathrm{C}$. The formation of these complex components cannot be predicted from simple thermodynamic calculations. Furthermore these complex 
components will not contribute to the reduction reaction unless they first are converted into $\mathrm{CO}, \mathrm{H}_{2}$ or $\mathrm{C}$. Side reactions that eventually determine the final gas compositions when pyrolysis oil is gasified, are discussed in the next paragraph.

\subsubsection{Side reactions}

The main side reactions that are expected are predominantly between the gaseous products obtained, like $\mathrm{CO}, \mathrm{CO}_{2}, \mathrm{H}_{2} \mathrm{O}, \mathrm{H}_{2}, \mathrm{CH}_{4}$, hydrocarbons and carbon.

\section{Boudouard reaction}

The Boudouard equilibrium results in the disproportionation of carbon monoxide into carbon and carbon dioxide at temperatures below $700{ }^{\circ} \mathrm{C}\left(\Delta \mathrm{G}_{\mathrm{r}}<0\right.$ for $\mathrm{T}>{ }^{\circ} \mathrm{C}$ for reaction 10$)$.

\begin{tabular}{|c|c|c|}
\hline \# & Boudouard reaction & $\begin{array}{l}\Delta \mathrm{H}_{\mathrm{r}}(\mathrm{kJ} / \mathrm{mole}) \\
\left(\mathrm{P}=1 \text { bar, } \mathrm{T}=827^{\circ} \mathrm{C}\right)\end{array}$ \\
\hline 10 & $\mathrm{C}(\mathrm{s})+\mathrm{CO}_{2}$ & -170 \\
\hline
\end{tabular}

Therefore, from a thermodynamic point of view, reduction of iron oxide cannot take place with carbon monoxide at temperatures below $700{ }^{\circ} \mathrm{C}$, as it is more favored to form $\mathrm{C}$ and $\mathrm{CO}_{2}$ below this temperature. When carbon monoxide is produced via the Boudouard reaction an increase of the amount of gaseous molecules is expected (going from right to left in reaction (10)). Therefore the increase of pressure has a negative effect on the formation of carbon monoxide and thus the reduction of iron oxide. More carbon is formed when the pressure increases and the Boudouard equilibrium will shift to the right.

\section{Water gas shift reaction}

The water-gas shift reaction plays an important role in the final gas composition:

\begin{tabular}{llll}
\hline$\#$ & Water gas shift reaction & & $\begin{array}{l}\Delta \mathrm{H}_{\mathrm{r}}(\mathrm{kJ} / \mathrm{mole}) \\
\left(\mathrm{P}=1 \mathrm{bar}, \mathrm{T}=827^{\circ} \mathrm{C}\right)\end{array}$ \\
\hline 11 & $\mathrm{H}_{2} \mathrm{O}+\mathrm{CO} \quad \leftrightarrow \quad \mathrm{H}_{2}+\mathrm{CO}_{2}$ & -34
\end{tabular}

Due to the exothermic character of reaction 11 an increase in temperature will shift the water gas shift reaction to the left. Furthermore, magnetite is a known high 
temperature water-gas shift catalyst for the production of hydrogen [26]. Thus, in general, it can be expected that at the temperatures applied for the steam-iron process $\left(>700{ }^{\circ} \mathrm{C}\right)$ the water-gas shift equilibrium is maintained throughout the system. Since the reduction with hydrogen is faster than the reduction with carbon monoxide, almost all of the carbon monoxide conversion is affected by the water gas shift reaction, which then controls the concentration of the carbon oxides in the system [3].

\section{Methanation}

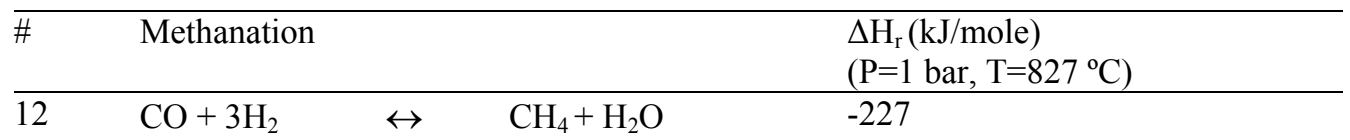

The methanation reaction will only take place at high hydrogen concentrations and is favored for the production of methane at high pressures. Methane is a stable compound, because of its large endothermic reforming enthalpy. Therefore only at temperatures above $1100^{\circ} \mathrm{C}$ it is expected that methane will be converted to hydrogen and carbon monoxide.

\section{Steam reforming}

\begin{tabular}{ll}
\hline$\#$ & Steam reforming \\
\hline $13 \quad \mathrm{C}_{\mathrm{x}} \mathrm{H}_{\mathrm{y}}+\mathrm{xH}_{2} \mathrm{O} \leftrightarrow \mathrm{x} \mathrm{CO}+(\mathrm{x}+\mathrm{y} / 2) \mathrm{H}_{2}$
\end{tabular}

The hydrocarbons that are formed during the cracking of the pyrolysis oil can react with the steam (about 30 wt \% of the oil consists of water). Based on thermodynamics reforming should be complete with $\mathrm{C}_{2} \mathrm{H}_{6}$ and larger hydrocarbons for temperatures above $25{ }^{\circ} \mathrm{C}$. In practice the endothermic steam reforming reaction is normally performed in the presence of a nickel-based or mineral-based catalysts at low temperatures $\left(<1000{ }^{\circ} \mathrm{C}\right)$ or without a catalyst at high temperatures $\left(>1200^{\circ} \mathrm{C}\right)$. 


\subsubsection{Equilibrium gas composition of gasified pyrolysis oil}

The pyrolysis oil used consists of many different organic compounds and thus a thermodynamic calculation can only be based on the elemental composition of the pyrolysis oil (Table 2.4).

Table 2.4: Elemental composition and water content of beech pyrolysis oil.

\begin{tabular}{ll}
\hline (wet oil) & wt \% \\
\hline $\mathrm{C}$ & 40.7 \\
$\mathrm{H}$ & 8.2 \\
$\mathrm{O}^{*}$ & 51.1 \\
& \\
$\mathrm{H}_{2} \mathrm{O}$ & 28.3 \\
\hline
\end{tabular}

*Determined by difference

The equilibrium gas composition of gasified pyrolysis oil is based on Gibbs energy minimization. In the gas equilibrium calculation it is assumed that the formed products are $\mathrm{CO}, \mathrm{CO}_{2}, \mathrm{H}_{2} \mathrm{O}, \mathrm{H}_{2}, \mathrm{CH}_{4}$ and solid $\mathrm{C}$. The mole fractions of the produced gases from pyrolysis oil and the carbon formation at equilibrium at different temperatures are shown in Figure 2.11 and 2.12.

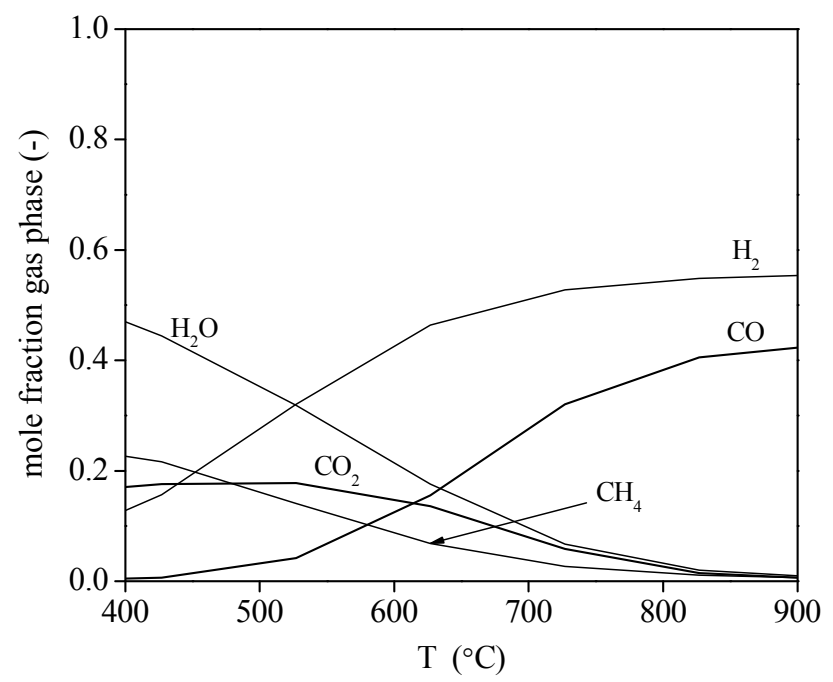

Figure 2.11: Equilibrium composition at different temperatures for pyrolysis oil (composition of the pyrolysis oil is given in Table 2.4). 


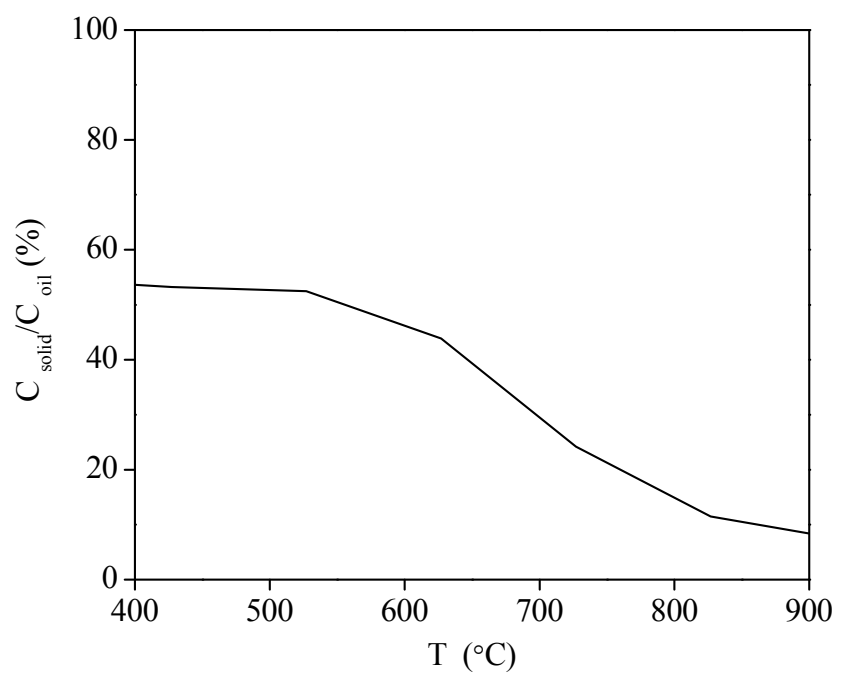

Figure 2.12: Carbon formation of pyrolysis oil (composition of the pyrolysis oil is given in Table 2.4:) at equilibrium for different temperatures.

The carbon atoms present in the oil are partly converted into solid carbon $\left(\mathrm{C}_{\text {solid }}\right)$ during gasification (Figure 2.12). The solid carbon formation can be reduced to a minimum of $5.9 \%$ by increasing the temperature. A lower carbon formation is not possible due to the low oxygen content in the pyrolysis oil $(\mathrm{C} / \mathrm{O}=1.06)$, which is not sufficient to convert all carbon into carbon monoxide.

The gas products obtained from the gasification of pyrolysis oil can be used for the reduction of the iron oxide. The reducing capacity of this gas is determined by the $\mathrm{CO} / \mathrm{CO}_{2}$ and $\mathrm{H}_{2} / \mathrm{H}_{2} \mathrm{O}$ ratios in the gas phase. A reduction reaction will take place if the $\mathrm{CO} / \mathrm{CO}_{2}$ or $\mathrm{H}_{2} / \mathrm{H}_{2} \mathrm{O}$ ratio in the gas phase is higher compared to the $\mathrm{CO} / \mathrm{CO}_{2}$ or $\mathrm{H}_{2} / \mathrm{H}_{2} \mathrm{O}$ ratio of a gas in equilibrium with the reduced iron oxide. In Table 2.5 the equilibrium $\mathrm{CO} / \mathrm{CO}_{2}$ and $\mathrm{H}_{2} / \mathrm{H}_{2} \mathrm{O}$ ratios of the different reduction reactions are compared with these ratios of the gas phase obtained after oil gasification. A reducing environment from the gasified pyrolysis oil gases can be expected at temperatures above $627{ }^{\circ} \mathrm{C}$. Theoretically, the reduction of wustite to iron is feasible with gasified pyrolysis oil above $727^{\circ} \mathrm{C}$. 
Table 2.5: Equilibrium $\mathrm{CO} / \mathrm{CO}_{2}$ and $\mathrm{H}_{2} / \mathrm{H}_{2} \mathrm{O}$ ratios in the gas phase after oil gasification and for the reversible reduction reactions of magnetite and wustite.

\begin{tabular}{lllllll}
\hline & \multicolumn{2}{l}{ Magnetite/Wustite } & \multicolumn{2}{l}{ Wustite/Iron } & \multicolumn{2}{l}{ Magnetite/Iron } \\
\hline $\mathrm{T}\left({ }^{\circ} \mathrm{C}\right)$ & $\mathrm{CO} / \mathrm{CO}_{2}$ & $\mathrm{H}_{2} / \mathrm{H}_{2} \mathrm{O}$ & $\mathrm{CO} / \mathrm{CO}_{2}$ & $\mathrm{H}_{2} / \mathrm{H}_{2} \mathrm{O}$ & $\mathrm{CO} / \mathrm{CO}_{2}$ & $\mathrm{H}_{2} / \mathrm{H}_{2} \mathrm{O}$ \\
\hline 427 & & & & & 0.85 & 8.05 \\
527 & & & & 1.01 & 4.28 \\
627 & 1.11 & 2.55 & 1.21 & 2.79 & & \\
727 & 0.77 & 1.10 & 1.58 & 2.27 & & \\
827 & 0.57 & 0.56 & 1.93 & 1.91 & & \\
927 & 0.45 & 0.32 & 2.26 & 1.65 & & \\
\hline
\end{tabular}

Pyrolysis oil

\begin{tabular}{lll}
\hline $\mathrm{T}\left({ }^{\circ} \mathrm{C}\right)$ & $\mathrm{CO} / \mathrm{CO}_{2}$ & $\mathrm{H}_{2} / \mathrm{H}_{2} \mathrm{O}$ \\
\hline 427 & 0.04 & 0.35 \\
527 & 0.24 & 1.01 \\
627 & 1.14 & 2.64 \\
727 & 5.47 & 7.87 \\
827 & 27.80 & 27.47 \\
927 & 122.74 & 89.53 \\
\hline
\end{tabular}

\subsubsection{Equilibrium gas composition of iron oxide reduction with gasified pyrolysis oil}

In this paragraph the gas composition of gasified pyrolysis oil in equilibrium with wustite is described. The reduction of magnetite to wustite with pyrolysis oil will take place when the temperature is above about $627{ }^{\circ} \mathrm{C}$. The mole fractions of the produced gases from pyrolysis oil in equilibrium with wustite at different temperatures are shown in Figure 2.13. This gas composition is obtained if all products from the gasification of oil (gas and solid, Figure 2.11 and 2.12) are contributing in the reduction of the iron oxide to wustite. 


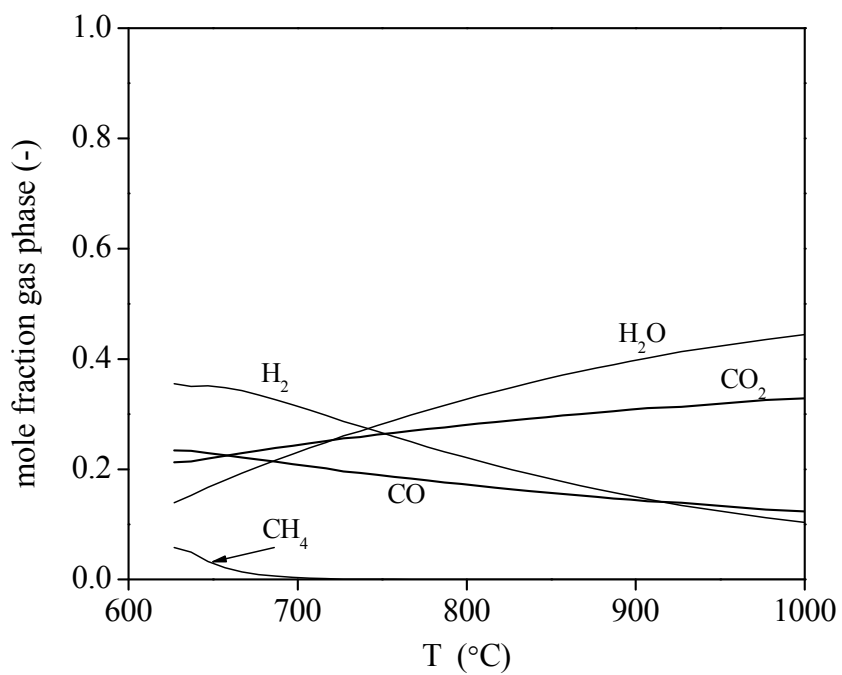

Figure 2.13: Equilibrium gas composition at different temperatures after the reduction of magnetite to wustite with pyrolysis oil .

Hardly any methane is expected from the pyrolysis oil at temperatures above $700{ }^{\circ} \mathrm{C}$. This is caused by the high water content in the gas phase, which is a result of the reduction reaction with hydrogen.

\subsubsection{Hydrogen production}

The maximum hydrogen production in the steam-iron process with pyrolysis oil can be calculated by assuming that the oil gasification products are reducing magnetite to wustite until equilibrium is obtained in the gas phase (in this case it is assumed that iron oxide is in excess). It is assumed that the gas phase is in equilibrium with the wustite phase as this results in a higher conversion in the gas phase compared to a full reduction to iron. This is a result of the more favorable equilibrium ratios (Table 2.5) for the reduction to wustite. During oxidation the wustite formed is assumed to be completely oxidized back to magnetite with steam. For this calculation two situations are considered. In the first calculation it is assumed that the formed solid carbon (Figure 2.12) does not participate in the reduction. This could be for example the case, when the solid carbon does not make any contact with the iron oxide surface and is not reacting with other gaseous reactants. In the second calculation it is assumed that the solid carbon reacts to an equilibrium ratio of $\mathrm{CO} / \mathrm{CO}_{2}$ for the reduction of magnetite to wustite. The results are given in Figure 2.14. 


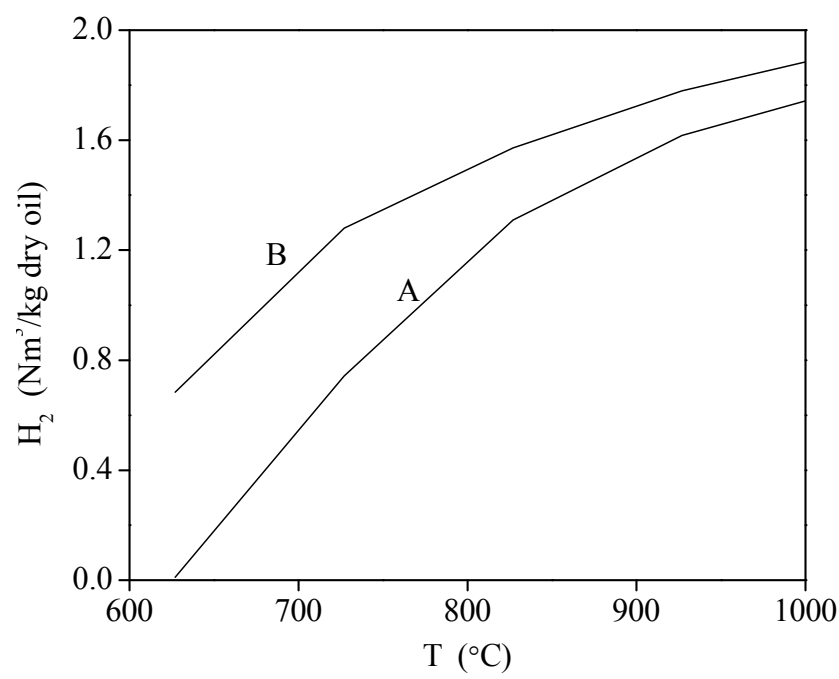

Figure 2.14: Theoretical pure $\mathrm{H}_{2}$ production in a redox cycle with pyrolysis oil at different temperatures. Line A: Formed solid carbon not participating in the reduction reaction. Line B: Formed solid carbon participating in reduction reaction.

It can be seen that the formed solid carbon from the gasification of oil has a large hydrogen production potential in the redox cycle especially at low temperatures when more solid carbon is expected. At $800{ }^{\circ} \mathrm{C}$ about $27 \%$ of the hydrogen production in the oxidation (difference between line A and B in Figure 2.14), is realized by the reaction of solid carbon with the iron oxide in the reduction. Carbon is a strong reducer as besides $\mathrm{CO}$ also $\mathrm{CO}_{2}$ can be produced from it.

\subsection{Process efficiency}

In this paragraph the overall process efficiency of the steam-iron process with pyrolysis oil as feedstock based on the previous equilibrium calculations will be discussed. The overall energy efficiency of the steam-iron process with pyrolysis oil for different experimental and theoretical cases is also described in Chapter 7. The process efficiency discussed in this chapter is based on the process design presented in Chapter 7. 


\subsubsection{Definitions}

The following assumptions were used for the calculations:

- The pyrolysis oil is gasified in the reductor.

- Equilibrium is obtained between the gasified oil and the iron oxide.

- The redox cycle of the iron oxide takes place between the magnetite and wustite phase.

- Separation of the $\mathrm{H}_{2}$ product from the $\mathrm{H}_{2} / \mathrm{H}_{2} \mathrm{O}$ mixture is performed by condensing the product stream obtained after oxidation.

- Additional energy needed for the process is obtained from the combustion of pyrolysis oil.

- System pressure is atmospheric (1 bar).

\section{Mass balance}

After the reduction of magnetite to wustite with pyrolysis oil, the gas composition as shown in Figure 2.13 is obtained for different process temperatures. In the oxidation with steam, the calculated hydrogen production per $\mathrm{kg}$ of dry oil as shown in Figure 2.14 line B is obtained.

\section{Energy balance and heat integration}

The energy balance is calculated from the mass balance for different process temperatures. The sensible heat of the hot gas streams in the process is used for heat integration which is discussed in more detail in Chapter 7. Combustion of the spent gases with air takes place in a furnace and the net heat produced in the furnace is defined as $\mathrm{Q}_{\text {furnace}}$. The sensible heat in the off gas from the furnace is matched to supply the heat required for the reduction reactor. If the energy content in the spent gas is not high enough to supply this heat $\left(\mathrm{Q}_{\text {furnace }}>0\right)$ additional oil needs to be combusted in the furnace.

The heat produced in the oxidation reactor can supply part of the heat required in the reduction reactor. The temperature in the oxidation reactor needs to be higher compared to the reduction reactor $\left(\mathrm{T}_{\mathrm{ox}}>\mathrm{T}_{\mathrm{red}}\right)$ to enable heat transport between both reactors. In this study the temperature difference $\left(\mathrm{T}_{\mathrm{ox}}-\mathrm{T}_{\mathrm{red}}\right)$ will be varied from 0 to 80 ${ }^{\circ} \mathrm{C}$. This temperature difference is varied by adjusting the amount of iron oxide circulated in the process. 
If the temperature difference is set to zero the oxidation reactor needs to be cooled and this heat is used for the production of steam. The heat produced in the oxidator can in this case exceed the heat required for the production of hot steam. The possible surplus of heat from the oxidator is defined as $\mathrm{Q}_{\mathrm{ox}}$. The amount of iron oxide circulated in the process is based on the stoichiometrie of the reduction reaction (all magnetite is fully reduced to wustite in the reductor) when the temperature difference $\left(\mathrm{T}_{\mathrm{ox}}-\mathrm{T}_{\text {red }}\right)$ is zero.

The heat required for the production of steam in the evaporator after heat integration is defined as $\mathrm{Q}_{\text {evaporator }}$. Heat required in the evaporator is obtained by the combustion of additional pyrolysis oil. The overall heat required in the process is the sum of $\mathrm{Q}_{\text {furnace }}$ and $\mathrm{Q}_{\text {evaporator }}$.

\section{Efficiency calculation}

The oil to hydrogen efficiency is defined as:

$$
\eta \mathrm{H}_{2}=\frac{\mathrm{M}_{\mathrm{H}_{2, \mathrm{ox}}}[\mathrm{kg}] \cdot \mathrm{LHV}_{\mathrm{H}_{2}}[\mathrm{MJ} / \mathrm{kg}]}{\mathrm{M}_{\text {oil }, \text { in }}[\mathrm{kg}] \cdot \mathrm{LHV}_{\text {oil }}[\mathrm{MJ} / \mathrm{kg}]} \cdot 100 \%
$$

in which $\mathrm{M}_{\mathrm{H} 2, \mathrm{ox}}$ is the amount of pure hydrogen produced in the oxidation from a certain amount of dry oil $\left(\mathrm{M}_{\mathrm{oil}}\right)$ in a redox cycle. The overall process efficiency is defined as:

$$
\eta_{\text {process }}=\frac{\mathrm{M}_{\mathrm{H}_{2, \text { ox }}}[\mathrm{kg}] \cdot \mathrm{LHV}_{\mathrm{H}_{2}}[\mathrm{MJ} / \mathrm{kg}]}{\left(\mathrm{M}_{\text {oil }, \text { in }}[\mathrm{kg}]+\mathrm{M}_{\text {oil } \text {,heat }}[\mathrm{kg}]\right) \cdot \mathrm{LHV}_{\text {oil }}[\mathrm{MJ} / \mathrm{kg}]} \cdot 100 \%
$$

In this case the heat required in the process is included and translated to oil equivalents $\left(\mathrm{M}_{\text {oil,heat }}\right)$. $\mathrm{M}_{\text {oil,heat }}$ is the amount of dry oil required in the process to supply the heat required $\left(\mathrm{Q}_{\text {furnace }}+\mathrm{Q}_{\text {evaporator }}\right)$.

\section{Heat of formation of pyrolysis oil}

The heat of formation of the specific oil used in this calculation is not determined experimentally. Therefore the heat of formation of pyrolysis oil is calculated from the average lower heating value found in literature $(22 \mathrm{MJ} / \mathrm{kg}$ dry oil) 
and the heat of formation of the products obtained after combustion of the oil $\left(\mathrm{CO}_{2}\right.$ and $\mathrm{H}_{2} \mathrm{O}$ ). In the calculations in this chapter the oil composition shown in Table 2.4 is used, which results in an estimated heat of formation of $-8324 \mathrm{~kJ} / \mathrm{kg}$ oil.

\subsubsection{Process efficiency of the steam iron process with pyrolysis oil at different temperatures}

The reduction potential of the pyrolysis oil improves by increasing the reaction temperature (see also section 2.4.6). This results in an increased hydrogen efficiency of the process with temperature as shown in Figure 2.15. Consequently the spent reducing gas contains less hydrogen and carbon monoxide and more $\mathrm{CO}_{2}$ and $\mathrm{H}_{2} \mathrm{O}$ with increasing temperature, resulting in a lower energy content of the spent reducing gas. The heat produced in the furnace will therefore be lower while more heat is required in the reductor at higher reaction temperatures. Both effects result in an increase in $\mathrm{Q}_{\text {furnace }}$ with temperature. Increasing the reaction temperature in the oxidator will result in a worsening of the steam conversion during oxidation. This is caused by the worsening equilibrium conditions for the oxidation at high temperatures (Bauer Gleasnner diagram, Figure 2.10). More steam passes through the oxidation reactor unreacted with increasing temperature, which needs to be cooled and condensed to separate the hydrogen product from the $\mathrm{H}_{2} / \mathrm{H}_{2} \mathrm{O}$ mixture and reheated for the oxidation reaction. Qevaporator will therefore increase when more steam is required in the oxidator with increasing temperature.

The process efficiency will be calculated for two different cases, for which a slightly different heat integration is applied: In the first case the temperature in the oxidator is equal to the temperature in the reductor $\left(\mathrm{T}_{\mathrm{red}}=\mathrm{T}_{\mathrm{ox}}\right)$. In the second case the temperature difference between the reductor and oxidator is varied $\left(\mathrm{T}_{\mathrm{red}} \neq \mathrm{T}_{\mathrm{ox}}\right)$.

\section{Case 1: $\mathbf{T}_{\text {red }}=\mathbf{T}_{\mathbf{o x}}$}

Table 2.6 shows that the process conducted at $627{ }^{\circ} \mathrm{C}$ is overall exothermic and no additional oil is required for heat production. Below $877^{\circ} \mathrm{C}$ the heat produced in the oxidator is more than sufficient to produce the hot steam required in the process $\left(\mathrm{Q}_{\text {evaporator }}=0\right.$ and $\left.\mathrm{Q}_{\mathrm{ox}}<0\right)$. This surplus of heat cannot be transported to the reduction reactor when $\mathrm{T}_{\mathrm{ox}}=\mathrm{T}_{\text {red. }}$. It would have been beneficial to transport this heat to the reduction reactor by choosing a higher oxidation temperature to lower $\mathrm{Q}_{\text {furnace }}$. The total amount of additional oil required per $\mathrm{kg}$ oil fed to the process to satisfy the heat 
required in the process is shown in Table 2.6. From the total oil requirement the process efficiency is calculated (Figure 2.15).

Table 2.6: Additional oil required (per kg oil fed to the reductor) to supply the heat required in the process at different process temperatures. $T_{\text {process }}=T_{0 x}=T_{\text {red }}$.

\begin{tabular}{lllll}
\hline $\begin{array}{l}\mathrm{T}_{\text {process }} \\
\left({ }^{\circ} \mathrm{C}\right)\end{array}$ & $\begin{array}{l}\mathrm{Q}_{\text {furnace }} \\
(\mathrm{kJ})\end{array}$ & $\begin{array}{l}\mathrm{Q}_{\text {evaporator }} \\
(\mathrm{kJ})\end{array}$ & $\begin{array}{l}\mathrm{Q}_{\text {ox }} \\
(\mathrm{kJ})\end{array}$ & $\begin{array}{l}\text { Additional oil } \\
\text { (for process heat) } \\
(\text { wet kg) }\end{array}$ \\
\hline 627 & -3190 & 0 & -3079 & - \\
727 & 2330 & 0 & -3026 & 0.26 \\
777 & 3948 & 0 & -2248 & 0.29 \\
827 & 5269 & 0 & -1139 & 0.38 \\
877 & 6465 & 83 & 0 & 0.48 \\
927 & 7506 & 1928 & 0 & 0.69 \\
977 & 8458 & 3961 & 0 & 0.90 \\
1027 & 9243 & 6617 & 0 & 1.13 \\
\hline
\end{tabular}

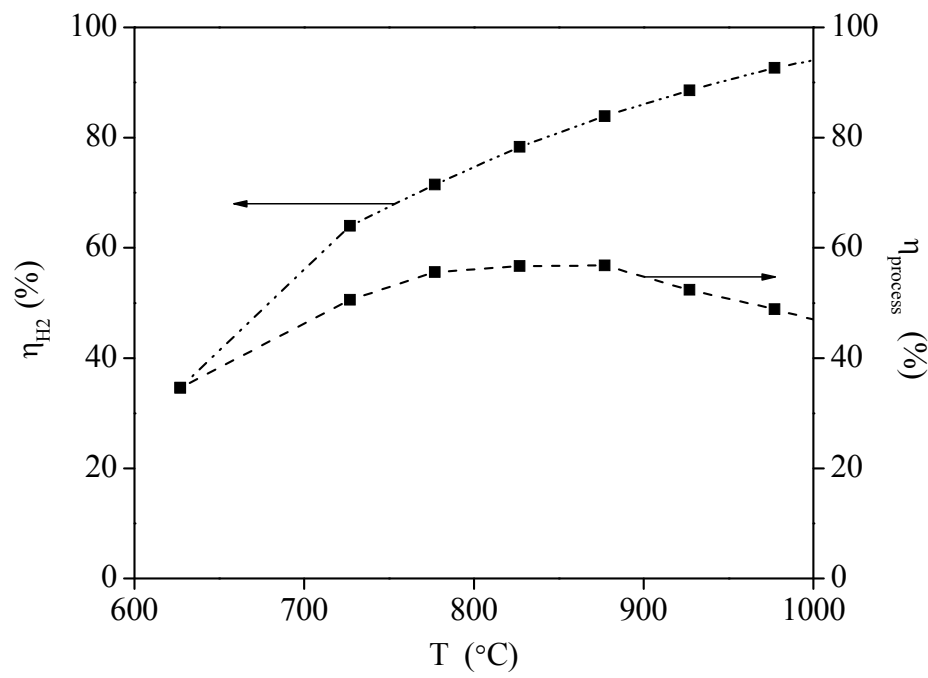

Figure 2.15: The hydrogen efficiency $\left(\eta \mathrm{H}_{2}\right)$ and the process efficiency ( $\eta$ process) of the production of hydrogen from oil in a redox cycle between magnetite and wustite.

Figure 2.15 shows that the hydrogen efficiency increases with temperature, while the overall process energy shows an optimum. The maximum process efficiency is obtained at a temperature of $877{ }^{\circ} \mathrm{C}(\eta$ process $=56.8 \%)$. An optimum in the 
process efficiency exists due to the fact that at low temperatures the conversion in the reductor is low and at high temperatures the conversion of steam in the oxidation becomes very low.

\section{Case 2: $\mathbf{T}_{\text {red }} \neq \mathbf{T}_{\text {ox }}$}

In the previous case the produced heat in the oxidator could not be transported to the reductor, which led to a high heat demand in the reductor. Choosing a higher oxidation temperature enables this transport, by using the solids (iron oxide) as transfer medium. This can be done if a circulating fluidized bed system is used, in which case the iron oxide/oil ratio and the temperature difference between the oxidator and reductor determine the heat flux into the reductor. In biomass gasification sand (non-catalytic) is usually used to transport heat from a combustor to the gasifier. In the combustor unreacted char from the biomass is combusted with air to supply the heat for the endothermic gasification [27]. Choosing a higher oxidation temperature will result in a relatively lower steam conversion in the oxidation reaction. Therefore the temperature difference between reductor and oxidator should be kept minimal, which can be done by increasing the iron oxide circulation rate in the process. In Figure 2.16 the $\mathrm{Fe}_{3} \mathrm{O}_{4} /$ oil ratio, required to obtain a certain increase in temperature in the oxidator $\left(\Delta \mathrm{T}=\mathrm{T}_{\mathrm{ox}}-\mathrm{T}_{\mathrm{red}}\right)$ is given. It is assumed that the total heat from the exothermic oxidation reaction is used for the temperature increase of the iron oxides. The figure shows that a small temperature difference of $20{ }^{\circ} \mathrm{C}$ requires a high circulation rate of iron oxides.

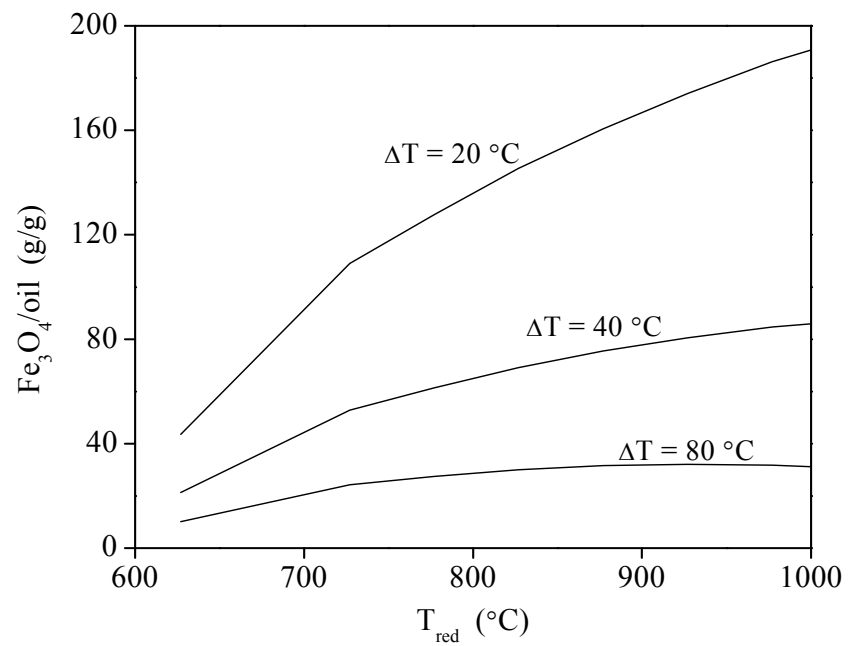

Figure 2.16: Required $\mathrm{Fe}_{3} \mathrm{O}_{4} /$ oil ratio (circulation rate) to obtain a specific temperature increase $\left(\Delta T=T_{o x}-T_{\text {red }}=0,40\right.$ and $\left.80^{\circ} \mathrm{C}\right)$ of the iron oxide in the oxidation step. 


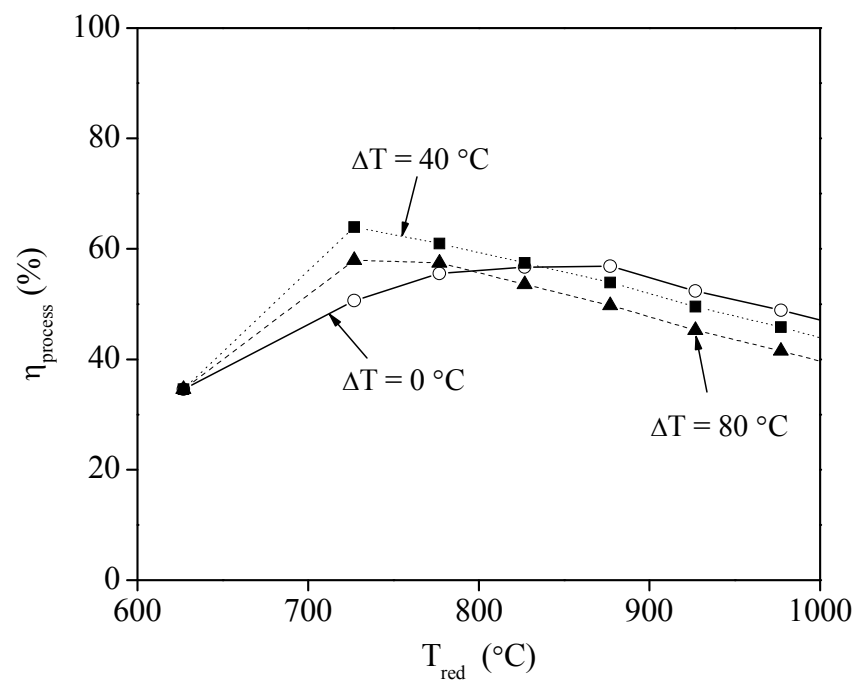

Figure 2.17: The process efficiency with heat exchange between reductor and oxidator for different $\Delta T\left(T_{0 x}-T_{\text {red }}\right)$.

Figure 2.17 shows that between $627-827{ }^{\circ} \mathrm{C}$ the transport of heat from oxidator to reductor results in a higher process efficiency. The highest process efficiency $\left(64.0 \%\right.$ at $\left.\mathrm{T}_{\text {red }}=727^{\circ} \mathrm{C}\right)$ is obtained with a temperature difference of 20-40 ${ }^{\circ} \mathrm{C}$. Choosing a higher temperature difference results in a slightly lower efficiency, but on the other hand requires a much lower circulation rate of iron oxides. Applying a temperature difference between reductor and oxidator results in a lower process efficiency when reduction temperatures higher than $827^{\circ} \mathrm{C}$ are applied, due to the unfavorable oxidation conditions.

\subsection{Conclusions}

The steam iron process should be seen as a purification step for the produced fuel gasses from gasified coal, oil or biomass. Most research groups agree that the limiting thermodynamic boundaries imposed by the use of iron oxide need to be improved to make the process more efficient. At high temperatures $>700{ }^{\circ} \mathrm{C}$ the reduction reaction seems sufficiently fast and the reaction is only thermodynamically limited. Improvement of these thermodynamic limitations are suggested by improving of the metal oxide itself, or by lowering the amount of water and carbon dioxide in the reduction gas used. The oxidation reaction is less discussed in literature and the steam 
conversion is always expected to be around the equilibrium conversion.

The thermodynamic evaluation of pyrolysis oil in the steam-iron process showed that a minimum temperature of about $627{ }^{\circ} \mathrm{C}$ is required for the reduction of magnetite to take place. A substantial amount of solid carbon is expected during the inert gasification of oil, which can contribute in the reduction if a contact between the iron oxide and the solid carbon is established. Increasing the temperature will enhance the reduction with pyrolysis oil from both a thermodynamic and kinetic point of view. On the other hand the equilibrium steam conversion in the oxidation will decrease with temperature. Both effects resulted in an optimum process temperature at $+/-727$ ${ }^{\circ} \mathrm{C}$. At this temperature a maximum hydrogen production of $1.30 \mathrm{Nm}^{3} / \mathrm{kg}$ dry oil can be achieved. The overall process efficiency is $64.0 \%$ (LHV based) at $727{ }^{\circ} \mathrm{C}$ with a temperature difference of $40{ }^{\circ} \mathrm{C}$ between reductor and oxidator. To maintain this temperature difference a circulation rate of $\mathrm{Fe}_{3} \mathrm{O}_{4} /$ oil of 76 is required.

In literature most redox processes with iron oxide are performed at temperatures above $800{ }^{\circ} \mathrm{C}$ for kinetic reasons. Furthermore gasification of pyrolysis oil will prove to be difficult at a temperature around $700{ }^{\circ} \mathrm{C}$. It will be necessary to experimentally determine the composition of the gas phase when pyrolysis oil is gasified. The formation of complex byproducts like tars, which probably do not contribute in the reduction, needs to be quantified. The experimental reducing capacity of pyrolysis oil will be discussed in the next chapter.

\subsection{Literature}

1 Meyer, R.J., Wasserstoff. 8 ed. Gmelins Handbuch der Anorganischen Chemie. Vol. 2., Weinheim, Bergstrasse, Verlag Chemie, GMBH., 1927.

2 Tarman, P.B. and R. Biljetina, Coal processing technology, 5 (1979) p. 114116.

3 Tarman, P.B. 5th Synthesis pipeline gas symposium. Chicago IL, Institute of Gas Technology, 1973.

4 Fukase, S. and T. Suzuka, Canadian Journal of Chemical Engineering, 72 (1994) p. 272-278.

5 Fukase, S. and T. Suzuka, Applied Catalysis A, 100 (1993) p. 1-17.

6 Hacker, V., Journal of power sources, 118 (2003) p. 311-314.

7 Hacker, V., et al., Journal of power sources, 86 (2000) p. 531-535.

8 Langins, J., Annals of Science, 40 (1983) p. 531-558. 
9 Hurst, S., Oil and soap, 16 (1939) p. 29-35.

10 Gasior, S.J., , U.S. D.o.t. Interior, Editor. Bureau of Mines, Washington. report of investigations 5911, 1961.

11 Tarman, P.B. $10^{\text {th }}$ Synthesis pipeline gas symposium. Chicago, Institute of Gas Technology, 1978.

12 Development of the steam-iron process for hydrogen production, Institute of Gas Technology:, Chicago, Illinois. p. 1-62. 1978.

13 Ullmann's Encyclopedia of Industrial Chemistry, 7th ed., John Wiley \& Sons, 2006.

14 Hacker, V., Journal of power sources, 71 (1998) p. 226-230.

15 Fraser, S.D., M. Monsberger, and V. Hacker, Journal of power sources, 161 (2006) p. 420-431

16 Sime, R., et al., International Journal of Hydrogen Energy, 28 (2003) p. 491498.

17 Ozaki, H., T. Murakami, and T. Suzuka. Symposium on processing heavy oils and residua, Seattle, 1983.

18 Otsuka, K., S. Murakoshi, and A. Morikawa, Fuel Processing Technology, 7 (1983) p. 203-211.

19 Otsuka, K., et al., Int. Journal of Hydrogen Energy, 26 (2001) p. 191-194.

20 Otsuka, K., et al., Journal of power sources, 122 (2003) p. 111-121.

21 Otsuka, K., et al., Int. Journal of Hydrogen Energy, 28 (2003) p. 335-342.

22 Seiler, H. and G. Emig, Chemical Engineering Technology, 21(1999) p. 479484.

23 Malcolm, W. and J. Chase, NIST-JANAF Thermochemical Tables. $4^{\text {th }}$ ed., Woodbury, NY, American Institute of Physics, 1998.

24 Bos, A., ECN-Fossiele Brandstoffen, Petten, 1994.

25 www.btgworld.com

26 Natesakhawat, S., et al., Journal of Molecular Catalysis A: Chemical, 260 (2006) p. 82-94.

27 Shen, L., Y. Gao, and J. Xiao, Biomass and Bioenergy, 32 (2008) p. 120-127. 


\title{
Chapter 3
}

\section{Redox experiments with pyrolysis oil in the fluidized bed (part I)}

\begin{abstract}
The use of pyrolysis oil in the steam-iron process to produce pure hydrogen is has been outlined in the previous chapter. In this chapter a detailed description of the various steps and related experimental procedures will be explained. The products of pyrolysis oil gasification are used to reduce iron oxides which are subsequently oxidized with steam, resulting in pure hydrogen. Two process alternatives are considered: i) a once-through concept in which cheap iron oxide (in our case sintered pellets of natural iron ore, $\mathrm{Fe}_{2} \mathrm{O}_{3}$ ) is used in one cycle, before further processing in a blast furnace, and ii) a continuous system, in which specially developed iron oxides (HT shift catalyst used in ammonia production processes) are cycled between a reduction and oxidation reactor. By injecting pyrolysis oil into a fluidized bed filled with $\mathrm{Fe}_{3} \mathrm{O}_{4}$ at $800{ }^{\circ} \mathrm{C}$, it has been shown that $\mathrm{CO}$ and $\mathrm{H}_{2}$ as well as coke produced by the gasification reactions contribute to the reduction. Experiments including a complete redox cycle with the iron oxide catalyst have shown that in the oxidation, a hydrogen production of $0.84 \mathrm{Nm}^{3} / \mathrm{kg}$ dry pyrolysis oil $\left(\mathrm{LHV} \mathrm{H}_{2} / \mathrm{LHV}\right.$ oil $\left.=0.4\right)$ can be obtained when only a small amount of iron oxide is allowed to participate in the cycle $(\sim 1.0 \%)$. The gas produced in the reduction step under these conditions still contains $38 \%$ of the heating value of the input and has an LHV of $7.8 \mathrm{MJ} / \mathrm{Nm}^{3}$ gas product. Deactivation of the iron oxides has been observed by a decreasing reduction rate in subsequent redox cycles. BET and SEM analysis showed a decrease in surface area, which could partly explain the observed deactivation.
\end{abstract}




\subsection{Steam-iron process with pyrolysis oil}

For the production of hydrogen from pyrolysis oil two processes are considered: Concept 1: A looping process that recycles a certain amount of iron oxides (per unit of feed) between a reduction and oxidation reactor (Figure 3.1 A). Concept 2 is a once through process that uses a batch of iron oxide for one reduction and oxidation step (Figure $3.1 \mathrm{~B}$ ). In both processes, the gas produced in the reduction step can be used for heating purposes (e.g. blast furnace) or can be upgraded to, for example, synthesis gas. The once-through concept may benefit from the possible heat integration near steel industries. It also reduces the burden on the lifetime of the iron oxide.

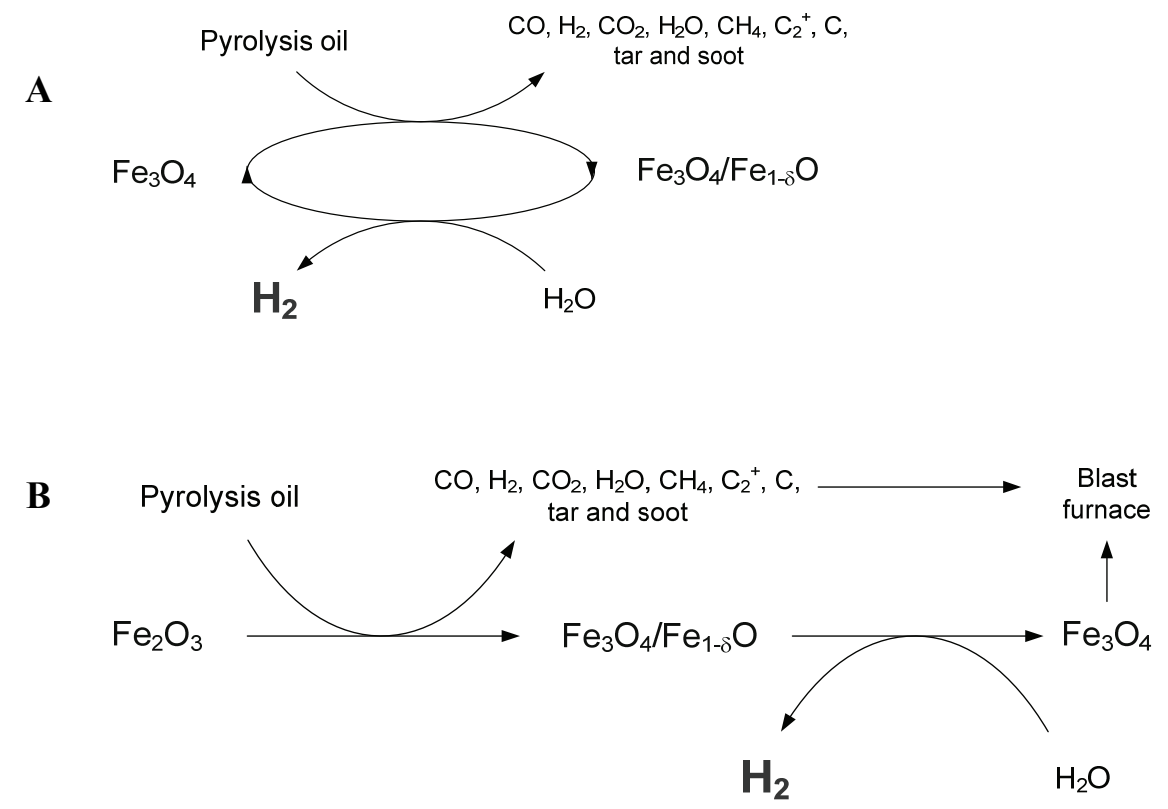

Figure 3.1: Steam iron process with pyrolysis oil: A) Recycling of iron oxide, B) Oncethrough process.

Temperatures used for the steam-iron process are in general around $800{ }^{\circ} \mathrm{C}$. When pyrolysis oil is gasified it will decompose into gaseous, liquid and solid products. With increasing temperature more gaseous products can be expected at the expense of the solid and liquid products. The gasification products $\mathrm{CO}, \mathrm{H}_{2}$ and $\mathrm{C}$ will reduce the iron oxide in the cycle basically, from magnetite to wustite $[9,10]$. The 
fresh iron oxide used consists of hematite $\left(\mathrm{Fe}_{2} \mathrm{O}_{3}\right)$ and is initially reduced to $\mathrm{Fe}_{3} \mathrm{O}_{4}$ resulting mainly in $\mathrm{CO}_{2}, \mathrm{H}_{2} \mathrm{O}$ and some $\mathrm{CH}_{4}$. This was observed from experiments performed in the fluidized bed with pyrolysis oil or ethanol as reducing agent. Reduction of iron oxides with hydrocarbons can take place, especially $\mathrm{Fe}_{2} \mathrm{O}_{3}$, but is slow for $\mathrm{Fe}_{3} \mathrm{O}_{4}$ and lower oxides [11]. Other products that are formed when pyrolysis oil is gasified, like $\mathrm{CH}_{4}$ and $\mathrm{C}_{2}^{+}$will therefore only substantially contribute to the reduction of $\mathrm{Fe}_{3} \mathrm{O}_{4}$ if they are converted to $\mathrm{CO}$ and $\mathrm{H}_{2}$ by e.g. steam reforming reactions [6]. Normally pyrolysis oil contains 15-35 wt $\%$ of $\mathrm{H}_{2} \mathrm{O}$, which would therefore be beneficial if the iron oxide works as a catalyst for steam reforming reactions of hydrocarbons and tars.

The hydrogen product is obtained after reoxidizing the iron oxide with steam in a separate step. Oxidation of $\mathrm{Fe}_{3} \mathrm{O}_{4} / \mathrm{Fe}_{1-\delta} \mathrm{O}$ with steam to $\mathrm{Fe}_{2} \mathrm{O}_{3}$ is thermodynamically impossible and oxidation to $\mathrm{Fe}_{2} \mathrm{O}_{3}$ can only be performed with oxygen $\left(\Delta \mathrm{G}_{\mathrm{r}}^{\mathrm{o}}\right.$ for the oxidation of $\mathrm{Fe}_{3} \mathrm{O}_{4}$ to $\mathrm{Fe}_{2} \mathrm{O}_{3}$ with steam is $58 \mathrm{~kJ} /(\mathrm{mol} \mathrm{H} \mathrm{H})$ at $\mathrm{T}=327{ }^{\circ} \mathrm{C}$ and $108 \mathrm{~kJ} /\left(\mathrm{mol} \mathrm{H}_{2} \mathrm{O}\right)$ at $\left.\mathrm{T}=927^{\circ} \mathrm{C}\right)$. Consequently, pyrolysis oil used for the reduction of $\mathrm{Fe}_{2} \mathrm{O}_{3}$ to $\mathrm{Fe}_{3} \mathrm{O}_{4}$ does not contribute to the production of hydrogen in the oxidation step.

Wustite is iron deficient and the iron:oxygen ratio in wustite can range between 0.83 and 0.95 [13]. The thermodynamic data used in our calculations assumes that wustite is present as $\mathrm{Fe}_{0.945} \mathrm{O}$ [14]. The atomic composition of the iron oxides produced in the experiments is not measured. In this thesis wustite will be assumed to be $\mathrm{Fe}_{0.945} \mathrm{O}$ in case thermodynamic calculations (Chapter 2) are considered, in all other cases it will be denoted as $\mathrm{Fe}_{1-\delta} \mathrm{O}$. The Bauer-Glaessner diagram (Figure 2.10) clearly shows that the total hydrogen production in the oxidation step is limited by the chemical equilibrium in the reduction step, because not all $\mathrm{CO}$ and $\mathrm{H}_{2}$ produced from gasified pyrolysis oil can be used for reduction. Furthermore it shows that a higher equilibrium conversion of steam to hydrogen is expected during oxidation when metal iron is formed during reduction and at lower temperatures, which is beneficial for the efficiency of the process. The reaction rate, on the other hand, will be slower at lower temperatures. 


\subsection{Experimental}

\subsubsection{Set-up}

The experimental set-up is shown in Figure 3.2. The set-up consists of a fluidized bed reactor (ID $0.078 \mathrm{~m}, \mathrm{~L} 1 \mathrm{~m}$ ). Hot fluidization gasses (nitrogen or air) and steam are entering the reactor in the lower conically shaped part of the reactor by four entrances. The preheated (reactor temperature) gasses and steam are blown tangentially along the wall of the reactor to enhance mixing of the gasses in the lower part of the reactor. Temperature sensors and differential pressure indicators are located along the wall of the reactor. Additional temperature sensors are measuring the temperature in the centre of the fluidized bed. Pyrolysis oil is fed with a dual head hose pump to the reactor via a cooled atomizer, which sprays a cold nitrogen/pyrolysis oil mixture into the lower conical mixing zone of the reactor. The atomizer transforms the pyrolysis oil into a mist of small droplets via a spraying nozzle. The nozzle mixes the nitrogen and pyrolysis oil in an internal mixing chamber before entering the reactor. The atomizer is designed for a minimum water flow of $0.5 \mathrm{~kg} / \mathrm{hr}$ at ambient conditions. Cooling of the atomizer is necessary to prevent the pyrolysis oil from polymerizing, which may already occur at $200{ }^{\circ} \mathrm{C}$, before entering the reactor. Therefore, the atomizer temperature is maintained below $100{ }^{\circ} \mathrm{C}$, to prevent boiling of the water in the pyrolysis oil as well. The temperature of the atomizer head is measured with a temperature sensor.

Gases from the reactor pass through a small cyclone, to separate small particles that are entrained with the product gas. The amount of particles collected in the cyclone is measured after each reaction. Two water coolers collect the condensed water and other organic liquids that are formed during reaction. The amount of condensate is collected and weighed after the reaction. A demister is installed in the case not all vapors are condensed in the coolers. Eventually a gas sample is pumped through the gas analysis unit. This unit included filters, to capture aerosols and other unwanted by products, a gas cooler operating at $5{ }^{\circ} \mathrm{C}$, to maintain a constant analysis temperature through al experiments, and analyzers. Gasses are analyzed by online analyzers for $\mathrm{CO}, \mathrm{CO}_{2}, \mathrm{CH}_{4}$ (IR) and $\mathrm{H}_{2}$ (TCD). A gas chromatograph is used to analyze hydrocarbons $\left(\mathrm{C}_{2}\right.$ and $\left.\mathrm{C}_{3}\right)$. 


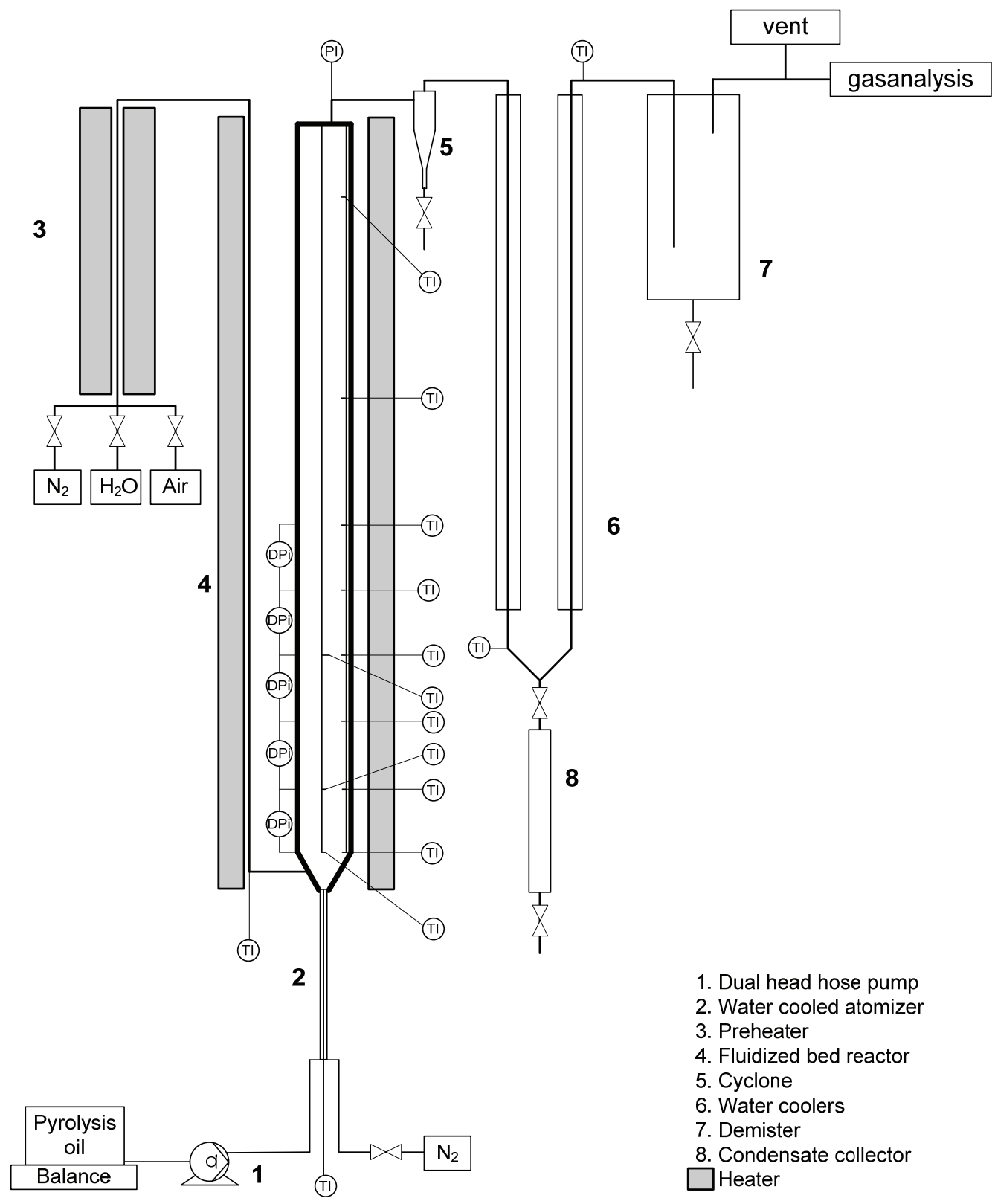

Figure 3.2: Schematic overview of the fluidized bed set-up. 


\subsubsection{Materials}

Pyrolysis oil from the pyrolysis of pine wood is obtained from the Biomass Technology Group (Enschede, the Netherlands). The composition of the pyrolysis oil is given in Table 3.1.

Table 3.1: Elemental composition and water content of the pyrolysis oil.

\begin{tabular}{ll}
\hline Component & Wt \% (wet) \\
\hline $\mathrm{C}$ & 40.7 \\
$\mathrm{H}$ & 8.22 \\
$\mathrm{O}^{*}$ & 50.9 \\
$\mathrm{~N}$ & 0.14 \\
\hline $\mathrm{H}_{2} \mathrm{O}$ & 28.3
\end{tabular}

* Determined by difference

Sand with an average particle size of $300 \mu \mathrm{m}$ and density of $2400 \mathrm{~kg} / \mathrm{m}^{3}$ is applied as bed material when non-catalytic pyrolysis oil gasification is studied. Two types of iron oxides are used: i) a catalytic iron oxide (BIC iron oxide), normally used in the ammonia industry, made by the Boreskov Institute of Catalysis (Novosibirsk, Russia), and ii) grinded sintered pellets, used for steel production in blast furnaces from CORUS (Ymuiden, The Netherlands). The sintered pellets applied in the experiments will be referred to as BF and BF I. The compositions are given in Table 3.2 . 
Table 3.2: Composition and properties of the iron oxides used.

\begin{tabular}{llll}
\hline & $\mathrm{BIC}$ & $\begin{array}{l}\mathrm{BF} \\
\text { sintered pellets } \\
(\mathrm{wt} \%)\end{array}$ & $\begin{array}{l}\text { BF I } \\
\text { sintered pellets } \\
(\mathrm{wt} \%)\end{array}$ \\
\hline $\mathrm{Fe}_{2} \mathrm{O}_{3}$ & $\mathrm{wt} \%)$ & 93.2 \\
$\mathrm{Cr}_{2} \mathrm{O}_{3}$ & 87.9 & 95.1 & \\
$\mathrm{CuO}$ & 9.2 & & 0.07 \\
$\mathrm{SiO}$ & 2.7 & 0.08 & 5.41 \\
$\mathrm{MgO}$ & & 2.21 & 0.18 \\
$\mathrm{CaO}$ & & 1.47 & 0.60 \\
$\mathrm{Al}$ & & 0.43 & 0.36 \\
$\mathrm{TiO}_{2}$ & 0.03 & 0.30 & 0.02 \\
$\mathrm{MnO}$ & & 0.24 & 0.05 \\
$\mathrm{~K}_{2} \mathrm{O}$ & 0.27 & 0.09 & 0.13 \\
${\mathrm{BET}\left(\mathrm{m}^{2} / \mathrm{g}\right)}_{\mathrm{Average} \mathrm{d}}(\mathrm{mm})$ & 1.0 and 0.7 & 0.04 & 0.23 \\
\hline
\end{tabular}

\subsubsection{Experimental procedures}

\section{Pyrolysis oil gasification in a fluidized sand bed}

The pyrolysis oil is sprayed at a constant flow rate in the fluidized bed reactor filled with sand particles. Additional hot nitrogen is used for fluidization. After injection of the pyrolysis oil, burning of the cokes on the sand particles is performed with air. The settings for the gasification experiments are given in Table 3.3.

Table 3.3: Experimental settings for the gasification experiments in the fluidized sand bed.

\begin{tabular}{llll}
\hline & & Gasification & $\begin{array}{l}\text { Burning } \\
\text { deposited coke }\end{array}$ \\
\hline$\Phi_{\mathrm{m}}$ pyrolysis oil & $(\mathrm{kg} / \mathrm{hr})$ & 0.5 & - \\
$\Phi_{\mathrm{v}} \mathrm{N}_{2}$ atomizer & $(\mathrm{Nl} / \mathrm{min})$ & 6.1 & 6.1 \\
$\Phi_{\mathrm{v}} \mathrm{N}_{2}$ hot & $(\mathrm{N} 1 / \mathrm{min})$ & 6.0 & - \\
$\Phi_{\mathrm{v}}$ Air_hot & $(\mathrm{Nl} / \mathrm{min})$ & - & 3.9 \\
$\mathrm{u}_{\text {reactor }}\left(\mathrm{T}=800^{\circ} \mathrm{C}\right)^{*}$ & $(\mathrm{~m} / \mathrm{s})$ & $0.22\left(9.7 \cdot \mathrm{u}_{\mathrm{mf}}\right)$ & $0.14\left(8 \cdot \mathrm{u}_{\mathrm{mf}}\right)$ \\
$\mathrm{M}$ bed & $(\mathrm{kg})$ & 1.5 & 1.5 \\
L bed & $(\mathrm{m})$ & 0.21 & \\
\hline$*$ Minimum fluidization velocity $\left(\mathrm{u}_{\mathrm{mf}}\right)$ is calculated at $800^{\circ} \mathrm{C}$ from $[15]$.
\end{tabular}

The temperature in the reactor is influenced by pyrolysis oil injection and by endo- and exothermic reactions. Therefore, when an experiment is started the 
temperature in the reactor drops or increases depending on the experimental settings. The temperature is measured at several places in the bed, to check temperature differences in the fluidized bed. Three thermocouples in the centre and four near the wall of the reactor never showed a higher $\Delta \mathrm{T}$ than $5{ }^{\circ} \mathrm{C}$ during reaction (in sand and iron oxide bed). During the gasification of pyrolysis oil over a sand bed a constant temperature was obtained after several minutes. This temperature was defined as the reaction temperature.

\section{Redox cycle}

One redox cycle consists of a reduction and an oxidation step. In the first part of the reduction step pyrolysis oil is injected in the fluidized bed and additional hot nitrogen is injected for fluidization of the bed. In this step, pyrolysis oil is gasified and iron oxides are reduced (reduction I). In the second part of the reduction (reduction II), only hot nitrogen is introduced in the reactor to allow the slower reaction of deposited carbon and iron oxide to complete. The oxidation step is performed with hot steam and nitrogen injected at reactor temperature. When the hydrogen production is approaching zero (below $0.07 \mathrm{Nl} / \mathrm{min}$ ) steam injection is stopped and the redox cycle is finished. Settings for the redox experiments are given in Table 3.4.

Table 3.4: Experimental settings for the redox experiments with fluidized iron oxides.

\begin{tabular}{lllll}
\hline & & Reduction (I) & Reduction (II) & Oxidation \\
\hline$\Phi_{\mathrm{m}}$ pyrolysis oil & $(\mathrm{kg} / \mathrm{hr})$ & 0.5 & - & - \\
$\Phi_{\mathrm{v}} \mathrm{N}_{2}$ atomizer & $(\mathrm{N} / \mathrm{min})$ & 6.1 & 6.1 & 2.2 \\
$\Phi_{\mathrm{v}} \mathrm{N}_{2}$ hot & $(\mathrm{Nl} / \mathrm{min})$ & 5.0 & 5.0 & 2.0 \\
$\Phi_{\mathrm{v}} \mathrm{H}_{2} \mathrm{O} \_$hot & $(\mathrm{kg} / \mathrm{hr})$ & - & - & 0.2 \\
$\mathrm{u}_{\text {reactor }}\left(\mathrm{T}=800^{\circ} \mathrm{C}\right)$ & $(\mathrm{m} / \mathrm{s})$ & 0.15 & 0.15 & 0.11 \\
$\mathrm{M}$ bed $\left(\mathrm{Fe}_{3} \mathrm{O}_{4}\right)$ & $(\mathrm{kg})$ & 1.7 & 1.7 & 1.7 \\
\hline
\end{tabular}

If iron oxide is used as bed material, an initial strong decrease in temperature is observed $\left(\max .50{ }^{\circ} \mathrm{C}\right)$ in the reduction step (Figure 3.7), due to the endothermic reduction reactions. During the second part of the reduction (no oil injection) the temperature rises again approaching the set-point of the controllers. The lowest temperature obtained in the bed during injection is defined as reactor temperature. When the oxidation is started a quick temperature increase towards a constant value (reaction temperature) is observed. 


\subsubsection{Atom balances, product yields and conversions}

Mass balances are obtained from the measured gas composition, flow rate of the gaseous products and the amount of pyrolysis oil fed to the system. The gases that are measured with the gas chromatograph and online analyzers used for the calculations are: $\mathrm{H}_{2}, \mathrm{CH}_{4}, \mathrm{CO}, \mathrm{CO}_{2}, \mathrm{C}_{2} \mathrm{H}_{4}, \mathrm{C}_{2} \mathrm{H}_{6}, \mathrm{C}_{3} \mathrm{H}_{6}$ and $\mathrm{C}_{3} \mathrm{H}_{8}$.

\section{Reduction and pyrolysis oil gasification}

Two integral carbon balances are calculated. The carbon conversion, $\zeta_{\mathrm{C} \text { to gas }}$, is defined as the amount of carbon transferred from the pyrolysis oil to gaseous products in reduction step I and in gasification tests in the fluidized sand bed. $\zeta_{\mathrm{C}}$ to gas is calculated from the gasses formed during the pyrolysis oil injection period.

$$
\zeta_{\mathrm{C} \text { to gas }}=\frac{\int_{\mathrm{t}_{\text {startoilinjection- } \tau_{\mathrm{d}}}\left(\Phi_{\mathrm{CO}}(\mathrm{t})+\Phi_{\mathrm{CO}_{2}}(\mathrm{t})+\Phi_{\mathrm{CH}_{4}}(\mathrm{t})+2 \Phi_{\mathrm{C}_{2} \mathrm{H}_{4}}(\mathrm{t})+2 \Phi_{\mathrm{C}_{2} \mathrm{H}_{6}}(\mathrm{t})+3 \Phi_{\mathrm{C}_{3} \mathrm{H}_{6}}(\mathrm{t})+3 \Phi_{\mathrm{C}_{3} \mathrm{H}_{8}}(\mathrm{t})\right) \mathrm{dt}}^{\mathrm{t}_{\text {endoilinjection } \tau_{\mathrm{d}}}} \int_{\mathrm{t}_{\text {startoilinjection }}}^{\mathrm{t}_{\text {endoilinjection }}} \frac{\Phi_{\mathrm{m}, \mathrm{oil}}(t) f_{c}}{M_{c}} \mathrm{dt}}{{ }_{\mathrm{c}}}
$$

In the equation above, $\Phi(\mathrm{t})$ represents the flow of gasses in $\mathrm{mol} / \mathrm{s}, \Phi_{\mathrm{m}, \mathrm{oil}}(\mathrm{t})$ is the oil feed rate in $\mathrm{kg} / \mathrm{s}, \mathrm{f}_{\mathrm{c}}$ is the mass fraction of carbon in pyrolysis oil, and $\mathrm{M}_{\mathrm{c}}$ is the molar mass of carbon. $\tau_{\mathrm{d}}$ is the delay (dead) time between the reactor and the gas analysis equipment. The delay is measured by gas pulse injection experiments, which also confirmed that it has plug-flow behavior.

Carbon that is deposited on the bed material is not included in this $\zeta_{\mathrm{C}}$ to gas. In order to measure the amount of deposited carbon air is applied to burn off the carbon in the case of the oil gasification experiments. If a redox experiment is performed, carbon is (partly) oxidized by the iron oxides. In both cases $\mathrm{CO}$ and $\mathrm{CO}_{2}$ is formed, which is included in the total carbon conversion balance, $\zeta_{\mathrm{C} \text { total. }} \zeta_{\mathrm{C} \text { total }}$ is $\zeta_{\mathrm{C}}$ to gas plus the amount of carbonaceous compounds deposited on the bed material and is used for the mass balance closure evaluation of the experiments. 


$$
\zeta_{\mathrm{C} \text { total }}=\zeta_{\mathrm{C} \text { to gas }}+\frac{\int_{\mathrm{t}_{\text {start air } / \mathrm{N}_{2} \text { injection }+\tau_{\mathrm{d}}}}^{\mathrm{t}_{\text {end air } / \mathrm{N}_{2} \text { injection }+\tau_{\mathrm{d}}}}\left(\int_{\mathrm{CO}}(\mathrm{t})+\Phi_{\mathrm{CO}_{2}}(\mathrm{t})\right) \mathrm{dt}}{\mathrm{t}_{\text {start oil injection }} \frac{\Phi_{\mathrm{m}, \mathrm{oil}}(t) f_{c}}{M_{c}} \mathrm{dt}}
$$

The momentary oxygen balance, $\zeta_{\mathrm{O}}$ to gas $(t)$, defined as the amount of oxygen transferred from the pyrolysis oil to gaseous products, is a measure for the reduction rate at a certain time in the reduction step. If the gases, initially produced by gasification of pyrolysis oil, reduce the iron oxides, the amount of oxygen in the product gas will be higher than the amount of oxygen fed with pyrolysis oil. Unfortunately it was not possible to measure the water content of the produced gases online. Therefore, the $\zeta_{\mathrm{o}}$ to gas is only indicative and is used qualitatively for e.g. the comparison between inert and catalytic experiments.

$$
\zeta_{\text {O to gas }}(\mathrm{t})=\frac{\Phi_{\mathrm{CO}}\left(\mathrm{t}+\tau_{\mathrm{d}}\right)+2 \Phi_{\mathrm{CO}_{2}}\left(\mathrm{t}+\tau_{\mathrm{d}}\right)}{\frac{\Phi_{\mathrm{m}, \mathrm{oil}}(t) f_{o}}{M_{o}}}
$$

In equation $3.3, \mathrm{f}_{\mathrm{O}}$ is the mass fraction of oxygen in pyrolysis oil (including water). Graphs containing $\zeta_{\mathrm{O} \text { to gas }}(t)$ are smoothened with the adjacent average method, in which the smoothed value at index $i$ is the average of the data points (with $n=5$ ) in the interval [i-(n-1)/2, $\mathrm{i}+(\mathrm{n}-1) / 2]$, inclusive.

Gas productions during gasification, reduction or oxidation are calculated as follows (example hydrogen production during reduction):

$$
\mathrm{H}_{2}=\frac{\int_{\mathrm{t} \text { start reduction }+\tau_{\mathrm{d}}}^{\mathrm{t} \text { end reduction }+\tau_{\mathrm{d}}} \Phi_{\mathrm{H}_{2}}(\mathrm{t}) \mathrm{dt} \cdot(\mathrm{RT} / \mathrm{P})}{\int_{\mathrm{t} \text { start oil injection }} \Phi_{\mathrm{m}, \mathrm{oil}}(\mathrm{t}) \cdot\left(1-\mathrm{X}_{\mathrm{m}, \mathrm{H}_{2} \mathrm{O}}\right) \mathrm{dt}} \quad\left(\mathrm{Nm}^{3} / \mathrm{kg} \text { dry oil }\right)
$$


in which $\mathrm{X}_{\mathrm{m}, \mathrm{H} 2 \mathrm{O}}$ is the water fraction in the pyrolysis oil, and $\mathrm{T}$ and $\mathrm{P}$ are defined at normal conditions ( $273 \mathrm{~K}$ and 1 bar).

In the reduction experiments pyrolysis oil is sprayed over a fluidized batch of $\mathrm{Fe}_{3} \mathrm{O}_{4}$. How much of this initially present iron oxide can be reduced, obviously depends on the amount of pyrolysis oil injected. However, the amount of $\mathrm{Fe}_{3} \mathrm{O}_{4}$ reduced is expected not to be linearly proportional to the amount of pyrolysis oil injected, as it has been reported by several researchers [7] that the reduction rate depends on the conversion level of the $\mathrm{Fe}_{3} \mathrm{O}_{4}$ particles. By evaluating the hydrogen production in the oxidation step per unit injected pyrolysis oil as a function of the amount $\mathrm{Fe}_{3} \mathrm{O}_{4}$, initially present per unit injected pyrolysis oil, an indication is obtained on the optimal iron oxide circulation rate $\left(\mathrm{kg} \mathrm{Fe}_{3} \mathrm{O}_{4} / \mathrm{s} / \mathrm{kg}\right.$ oil $\left./ \mathrm{s}\right)$ of the looping concept. To evaluate the total redox cycle the integral $(\mathrm{R})$ is used.

$$
\mathrm{R}=\frac{\mathrm{Fe}_{3} \mathrm{O}_{4} \text { initially present }}{\mathrm{t}_{\text {end oil injection }}}
$$

$1 / R(t)$, which is proportional to the runtime of the reduction, is used to discuss the momentary reduction rate during a single reduction test:

$$
\frac{1}{R(t)}=\frac{\int_{\text {start oil injection }}^{\mathrm{t}} \Phi_{\mathrm{m} \text { oil }}(\mathrm{t}) \mathrm{dt}}{\mathrm{Fe}_{3} \mathrm{O}_{4_{\text {initially present }}}}
$$

\section{Oxidation}

The amount of oxygen that is removed from the iron oxide during the reduction, $\Delta \mathrm{O}_{\text {iron oxide }}$ (moles), is calculated from the hydrogen produced in the oxidation step and corrected for hydrogen produced from char gasification reactions in the oxidation step. 


$$
\Delta \mathrm{O}_{\text {iron oxide }}=\int_{\mathrm{t}_{\text {start steam injection }+\tau_{\mathrm{d}}}}^{\mathrm{t}_{\text {end steam injection }+\tau_{\mathrm{d}}}}\left(\Phi_{\mathrm{H}_{2}}(\mathrm{t})-\Phi_{\mathrm{CO}}(\mathrm{t})-2 \Phi_{\mathrm{CO}_{2}}(\mathrm{t})\right) \mathrm{dt} \quad \text { (moles) }
$$

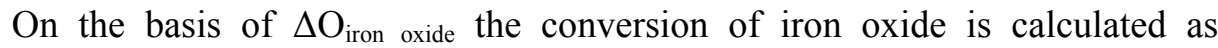
follows:

$$
\alpha\left(\mathrm{Fe}_{3} \mathrm{O}_{4}-\mathrm{Fe}\right)=\frac{\Delta \mathrm{O}_{\text {iron oxide }}}{\mathrm{S}_{0}} \cdot 100 \%
$$

In which $\mathrm{S}_{0}$ is the amount of oxygen (moles) initially present in $\mathrm{Fe}_{3} \mathrm{O}_{4}$ in the fluidized bed.

The momentary water conversion during oxidation with steam, which is equal to the amount of hydrogen produced in this step, is defined as:

$$
\zeta_{\mathrm{H}_{2} \mathrm{O}}(\mathrm{t})=\frac{\Phi_{\mathrm{H}_{2} \mathrm{O}, \text { in }}(\mathrm{t})-\Phi_{\mathrm{H}_{2} \mathrm{O}, \text { out }}\left(\mathrm{t}+\tau_{\mathrm{d}}\right)}{\Phi_{\mathrm{H}_{2} \mathrm{O}, \text { in }}(\mathrm{t})}=\frac{\Phi_{\mathrm{H}_{2}}\left(\mathrm{t}+\tau_{\mathrm{d}}\right)}{\Phi_{\mathrm{H}_{2} \mathrm{O}, \text { in }}(\mathrm{t})}
$$

The momentary steam converted to hydrogen by the conversion of carbon in the water gas reaction during oxidation resulting in the formation of $\mathrm{CO}$ and $\mathrm{CO}_{2}$, is defined as:

$\zeta_{\mathrm{H}_{2} \mathrm{O} \text { reacted with C }}(\mathrm{t})=\frac{\Phi_{\mathrm{CO}}\left(\mathrm{t}+\tau_{\mathrm{d}}\right)+2 \cdot \Phi_{\mathrm{CO}_{2}}\left(\mathrm{t}+\tau_{\mathrm{d}}\right)}{\Phi_{\mathrm{H}_{2} \mathrm{O}, \text { in }}(\mathrm{t})}$

A similar ratio $\mathrm{R}_{\mathrm{ox}}$ during the oxidation as during reduction $(\mathrm{R})$ is defined:

$$
\mathrm{R}_{\mathrm{ox}}=\frac{\mathrm{Fe}_{3} \mathrm{O}_{4 \text { initially present }}}{\mathrm{t}_{\text {end } \mathrm{H}_{2} \mathrm{O} \text { injection }}} \Phi_{\mathrm{m}_{\mathrm{H}, \mathrm{H}_{2} \mathrm{O}}(\mathrm{t}) \mathrm{dt}}
$$


In which the $\Phi_{\mathrm{m}, \mathrm{H} 2 \mathrm{O}}$ is the flow of water added to the system in $\mathrm{kg} / \mathrm{s}$. Also in this case, the inverse of the momentary $R_{0 x}$ is used to evaluate the oxidation rate during a single oxidation step.

$$
\frac{1}{\mathrm{R}_{\mathrm{ox}}(\mathrm{t})}=\frac{\int_{\mathrm{t}_{\text {start } \mathrm{H}_{2} \mathrm{O} \text { injection }}}^{\mathrm{t}} \Phi_{\mathrm{m}, \mathrm{H}_{2} \mathrm{O}}(\mathrm{t}) \mathrm{dt}}{\mathrm{Fe}_{3} \mathrm{O}_{4 \text { initially present }}}
$$

\subsection{Results}

\subsubsection{Mass balances}

A maximum carbon recovery ( $\left.\zeta \mathrm{C}_{\text {total }}\right)$ of $80 \%$ is obtained thus $20 \%$ of the carbon in the feed is not recovered in the experiments. Similarly, low carbon to gas conversions with pyrolysis oil are observed by Van Rossum et al. [16] and Panigrahi et al. [10] who found a conversion of biomass derived oil to the gas phase of $81 \%$ at $800{ }^{\circ} \mathrm{C}$. After the gasification experiments coolers and other cold parts in the set-up that are in contact with the gas effluent are contaminated with carbonaceous compounds (liquid and solid). A small fraction of the cokes particles that are formed could be separated with the cyclone (1-2 \% of the $\mathrm{C}$ input). Also $1-2 \mathrm{wt} \%$ of the carbon input is likely converted to tar [16]. The effect of spraying a cold pyrolysis oil into a hot fluidized bed probably causes formation of highly porous carbon structures which pass through the set-up and are not detected with the analysis methods [17].

\subsubsection{Gasification of pyrolysis oil and ethanol over a fluidized sand bed}

Gasification is conducted at temperatures between 650 and $970{ }^{\circ} \mathrm{C}$. A constant gas composition in time is observed and maintained for about 30-45 minutes.

\section{Pyrolysis oil}

The carbon conversion of the pyrolysis oil to the gas phase, which is a measure of the overall conversion of pyrolysis oil to the gas phase, increases from 51 $\%$ at $750{ }^{\circ} \mathrm{C}$ to $70 \%$ at $900{ }^{\circ} \mathrm{C}$, after which it leveled off to $950{ }^{\circ} \mathrm{C}$ (Figure 3.3). A slight decrease in $\zeta_{\mathrm{C} \text { to gas }}$ is observed at a temperature of $970{ }^{\circ} \mathrm{C}$. On average, around 
$5.1 \%$ of the carbon in the pyrolysis oil deposits on the sand particles, independent of the temperature.

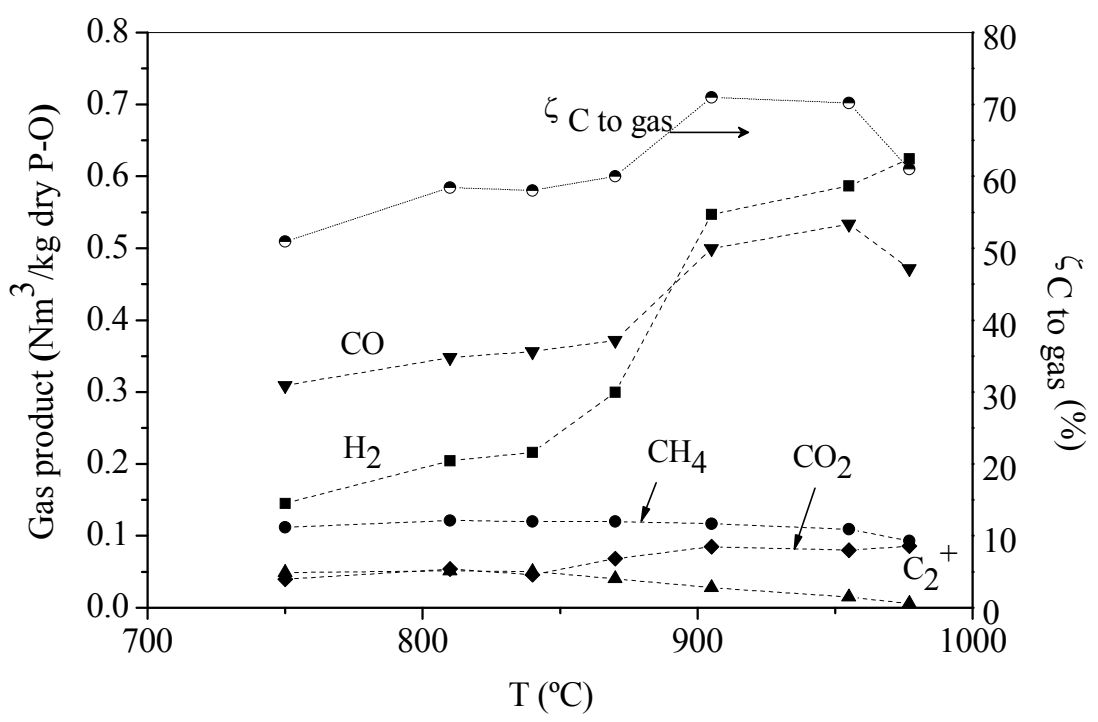

Figure 3.3: Pyrolysis oil gasification in the fluidized sand bed: gas production and carbon to gas conversion $\left(\zeta_{\mathrm{C} \text { to gas }}\right)$ at different reaction temperatures.

An overview of the measured gas production from the gasification of pyrolysis oil as a function of the reactor temperature is shown in Figure 3.3. Important for the reduction of iron oxide with pyrolysis oil is the formation of $\mathrm{CO}$ and $\mathrm{H}_{2}$. The production of these reducing compounds by gasification of pyrolysis oil increases with increasing temperature. This can be ascribed to the increase in carbon conversion, reforming of methane and $\mathrm{C}_{2}^{+}$compounds above $850{ }^{\circ} \mathrm{C}$, and probably the water-gasshift reaction. The methane concentration is not affected by temperature.

\section{Ethanol}

The gasification of ethanol is studied as a reference compound and to check the mass balance of the experimental set-up. Figure 3.5 shows that the carbon to gas conversion $(+/-92 \%)$ is stable at temperatures above $800{ }^{\circ} \mathrm{C}$. For all temperatures $\mathrm{CO}_{2}$ production is close to zero and also from the condensate measurements a low $\mathrm{H}_{2} \mathrm{O}$ concentration in the gas phase is expected. Consequently, increasing the gasification temperature of ethanol above $800{ }^{\circ} \mathrm{C}$ will not improve the reducing capacity of the gas product and also the methane production will remain high for all 
temperatures. A low $\mathrm{H}_{2} \mathrm{O}$ and $\mathrm{CO}_{2}$ concentration in the gas product result in a high reduction potential for the iron oxide.

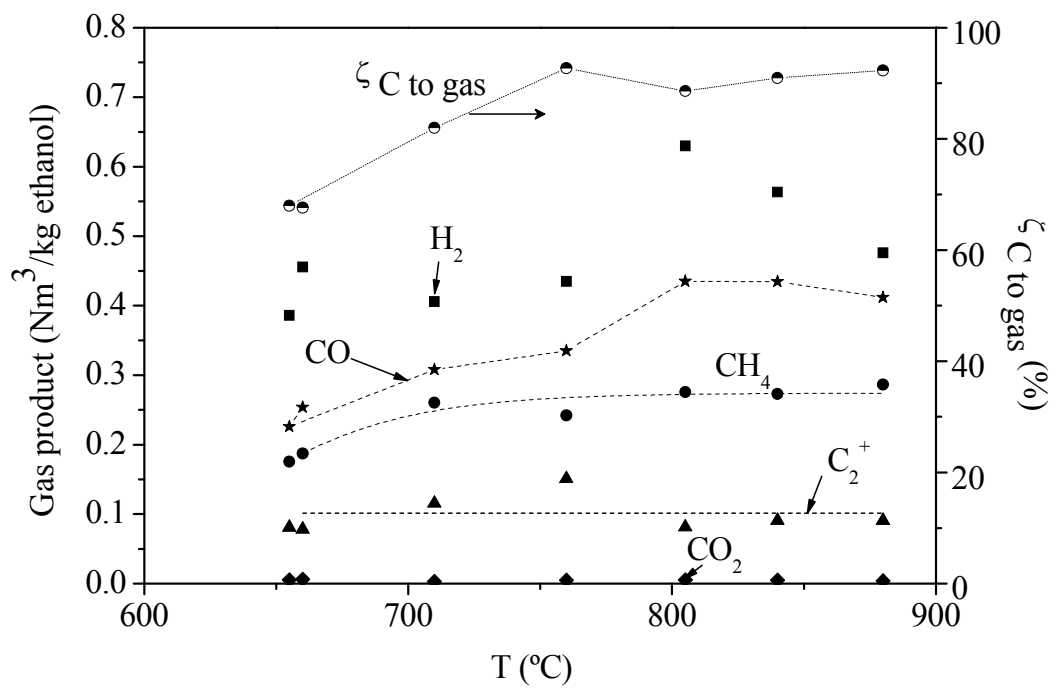

Figure 3.4: Ethanol gasification in the fluidized sand bed: gas production and carbon to gas conversion ( $\zeta_{\mathrm{C} \text { to gas }}$ ) at different reaction temperatures.

\subsubsection{Hydrogen potential}

The measured gas production as given in Figure 3.3 and 3.4 are used to estimate the amount of pure hydrogen that can be produced from pyrolysis oil and ethanol via the steam iron process (Figure 3.5) if the iron oxide used has no catalytic activity for reforming of $\mathrm{C}_{\mathrm{x}} \mathrm{H}_{\mathrm{y}}$, gasification of coke and the water-gas-shift. For this estimate, the chemical equilibrium of the produced gases and solid carbon (in the fluidized sand bed) with $\mathrm{Fe}_{3} \mathrm{O}_{4} / \mathrm{Fe}_{0.945} \mathrm{O}$ is calculated at the reactor temperature, which yields the maximum amount of $\mathrm{Fe}_{0.945} \mathrm{O}$ that can be produced from $\mathrm{Fe}_{3} \mathrm{O}_{4}$ per $\mathrm{kg}$ pyrolysis oil in the reduction. This amount of $\mathrm{Fe}_{0.945} \mathrm{O}$ then gives the hydrogen production (per kg pyrolysis oil/ethanol) in the oxidation step by assuming that the oxidation of $\mathrm{Fe}_{0.945} \mathrm{O}$ to $\mathrm{Fe}_{3} \mathrm{O}_{4}$ with steam is complete. These calculations predict that the hydrogen production with oil at the foreseen process temperature of $810{ }^{\circ} \mathrm{C}$ is 0.37 $\mathrm{Nm}^{3}$ per $\mathrm{kg}$ dry pyrolysis oil. The potential of hydrogen from ethanol is rather low at temperatures above $850{ }^{\circ} \mathrm{C}$ compared to pyrolysis oil, which is caused by the high methane production when ethanol is gasified (Figure 3.4). 
In section 3.4.9 "hydrogen production and potential" this predicted hydrogen production level will be compared with results obtained from redox cycle experiments.
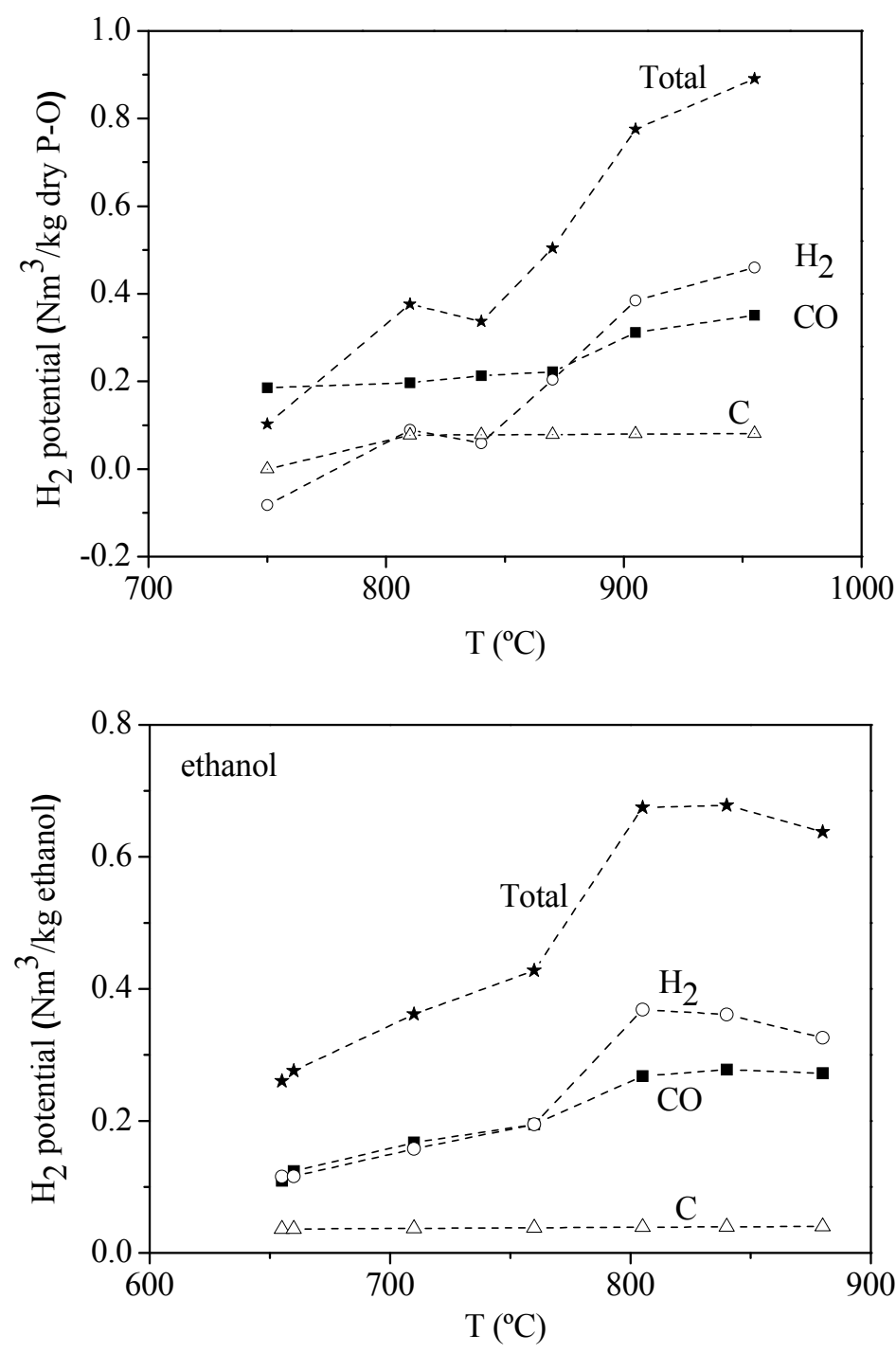

Figure 3.5: Calculated hydrogen production potential in the steam-iron process with gasified pyrolysis oil and ethanol. Experimental data of gasified pyrolysis oil or ethanol (Figure 3.3 and 3.4) is combined with equilibrium data of the reduction of magnetite to wustite with $\mathrm{C}, \mathrm{CO}$ and $\mathrm{H}_{2}$. 


\subsubsection{Gasification of pyrolysis oil over an iron oxide bed}

Below, a redox cycle ( $1^{\text {st }}$ cycle) using BIC iron oxide is described in detail. In Figure 3.6 the gas production of the product gas during this cycle is given versus the running time of the experiment. The temperature is also presented with the running time of the experiment (a short period of decrease in temperature between 70 and 75 minutes is caused by an external experimental problem). Table 3.5 lists time averaged results of this test. The starting temperature is set at $802{ }^{\circ} \mathrm{C}$ (set-point).

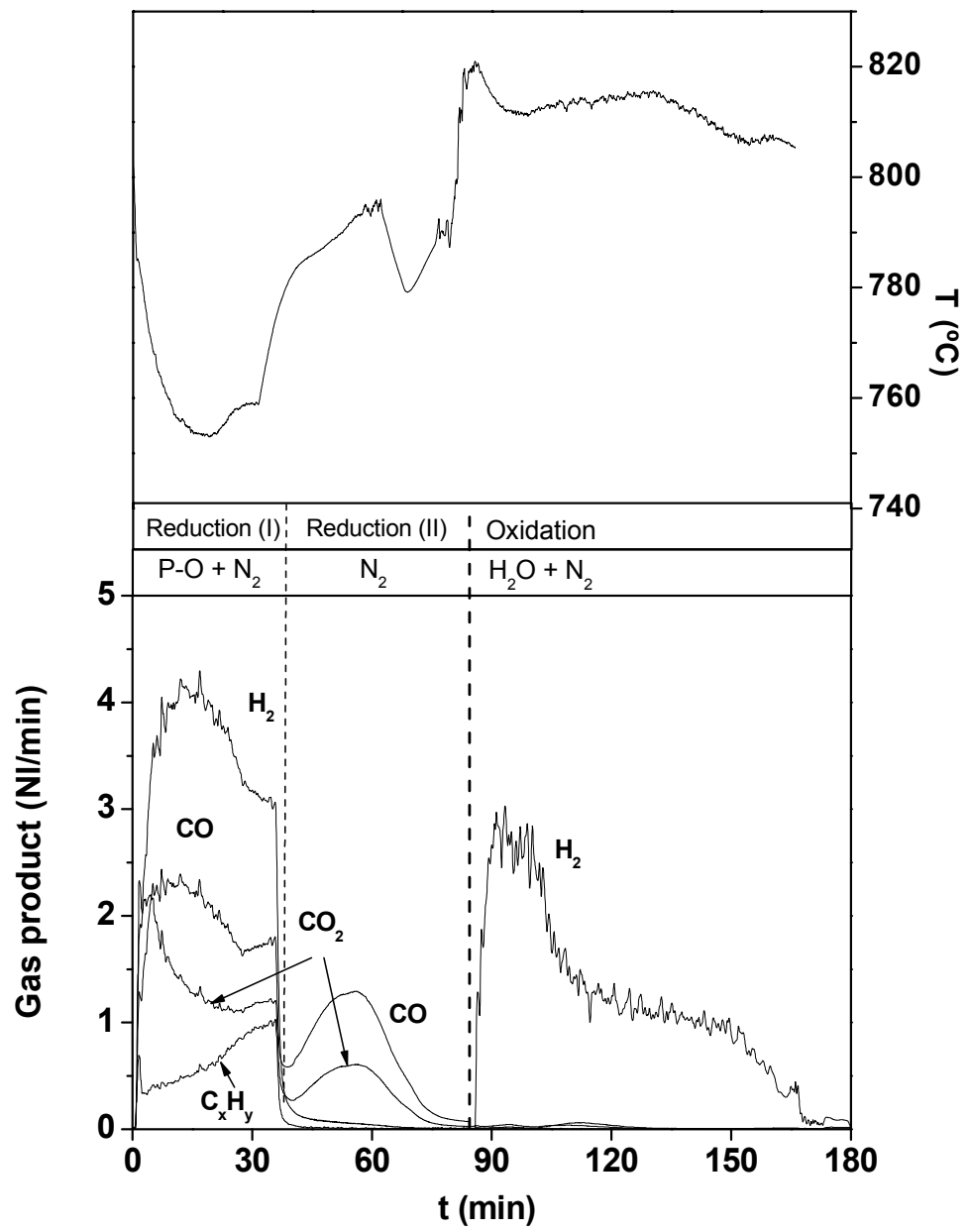

Figure 3.6: Gases produced and fluidized bed temperature during a redox cycle with pyrolysis oil (P-O) and BIC iron oxide. The presented temperature is the average temperature over the bed material. 
Table 3.5: Gas products from redox cycle (first cycle with BIC iron oxide) with $314 \mathrm{~g}$ pyrolysis oil and $1.75 \mathrm{~kg} \mathrm{Fe}_{3} \mathrm{O}_{4}$.

\begin{tabular}{|c|c|c|c|}
\hline & Red (I) & Red (II) & $\mathrm{Ox}$ \\
\hline Temperature & 754 & 761 & 810 \\
\hline \multicolumn{4}{|c|}{$\begin{array}{l}\text { Total average gas production } \\
\left(\mathrm{Nm}^{3} / \mathrm{kg} \text { dry-pyrolysis oil }\right)\end{array}$} \\
\hline $\mathrm{H}_{2}$ & 0.57 & - & 0.53 \\
\hline $\mathrm{CO}$ & 0.32 & 0.14 & 0.01 \\
\hline $\mathrm{CO}_{2}$ & 0.22 & 0.06 & 0.01 \\
\hline $\mathrm{CH}_{4}$ & 0.07 & - & - \\
\hline $\mathrm{C}_{2}+$ & 0.02 & - & - \\
\hline$\zeta \mathrm{C}$ to gas & 59.9 & & \\
\hline$\zeta \mathrm{C}$ total $-\zeta \mathrm{C}$ to gas & & 19.0 & \\
\hline \multicolumn{4}{|l|}{ Other } \\
\hline$\zeta_{\mathrm{H}_{2} \mathrm{O}}(t)_{t=90-105}$ & & $70 \%$ & \\
\hline$\zeta_{\mathrm{H}_{2} \mathrm{O}}(t)_{t=105-150}$ & & $30 \%$ & \\
\hline$\alpha\left(\mathrm{Fe}_{3} \mathrm{O}_{4}-\mathrm{Fe}\right)$ & & $15.3 \%$ & \\
\hline
\end{tabular}

\section{Reduction}

From 0 to 35 minutes, pyrolysis oil (Table 3.1) is injected with a constant flow rate. Contrary to the sand bed experiments no constant gas production is observed during pyrolysis oil injection. Most striking is the decrease of $\mathrm{CO}_{2}$ production during the first 15 minutes of injection, which points towards a decrease in the rate of the reduction reaction of $\mathrm{Fe}_{3} \mathrm{O}_{4}$ with $\mathrm{CO}$. The production of hydrogen is high during reduction step I (Figure 3.6): on average $0.57 \mathrm{H}_{2} \mathrm{Nm}^{3} / \mathrm{kg}$ dry pyrolysis oil compared with $0.21 \mathrm{H}_{2} \mathrm{Nm}^{3} / \mathrm{kg}$ dry pyrolysis oil over the fluidized sand bed. Probably reforming reactions of $\mathrm{C}_{\mathrm{x}} \mathrm{H}_{\mathrm{y}}$ are enhanced by the $\mathrm{BIC}$ iron oxide, resulting in lower $\mathrm{CH}_{4}$ and $\mathrm{C}_{2}^{+}$ production and higher $\mathrm{CO}$ and $\mathrm{H}_{2}$ production. After 20 minutes of pyrolysis oil injection, the catalytic activity of the iron oxide decreases, resulting in a higher $\mathrm{C}_{\mathrm{x}} \mathrm{H}_{\mathrm{y}}$ production and lower $\mathrm{CO}$ and $\mathrm{H}_{2}$ production. This decrease in catalytic activity could be due to the change of oxidation state of the iron oxide, but also by the deactivation due to carbon deposition on the particles. The gas produced during the reduction has a good $\mathrm{H}_{2} / \mathrm{CO}$ ratio (2:1) for further upgrading to a synthesis gas. The composition of this gas is dependent on the water content of the oil. Higher $\mathrm{H}_{2} / \mathrm{CO}$ ratios are found with a higher water content of the oil. The temperature during pyrolysis oil injection 
drops over a period of about 15 minutes, which after a slow increase in temperature is observed. When stopping the oil injection an increase towards the set-point is measured.

Carbon (coke) deposition can be clearly shown from the second part of the reduction ( 35 to 80 minutes) in which only nitrogen is injected. In this second part of the reduction, the coke that was deposited during pyrolysis oil injection is still reacting with the iron oxide producing $\mathrm{CO}, \mathrm{CO}_{2}$, and some $\mathrm{H}_{2}$. It can be calculated that a total of $19 \%$ of the carbon input is reacting in this second part of the reduction resulting in an $\alpha\left(\mathrm{Fe}_{3} \mathrm{O}_{4}-\mathrm{Fe}\right)$ of $8.7 \%$. For the total reduction period an $\alpha\left(\mathrm{Fe}_{3} \mathrm{O}_{4}-\mathrm{Fe}\right)$ of $15.3 \%$ is calculated. This means that more than half of the total reduction with pyrolysis oil is due to deposited coke on the iron oxide. The $\mathrm{CO} / \mathrm{CO}_{2}$ ratio of 2.2 found in the second part is high enough for the reaction of wustite to metal iron to take place.

\section{Oxidation}

At the start of the oxidation a high $\mathrm{H}_{2}$ production rate is obtained ( $\left.3 \mathrm{l} / \mathrm{min}\right)$, decreasing to $1.1 \mathrm{1} / \mathrm{min}$. At the maximum, $\mathrm{t}=90-100$ minutes, about $70 \%$ of the steam is converted to hydrogen, reducing to roughly $30 \%$ between $t=110-150$ minutes. The initial high conversion of steam could not be caused (based on thermodynamics) by the reaction of wustite with steam (Table 3.6). Probably metallic iron is formed during reduction resulting in a higher conversion of steam. The measured conversion of steam is higher than the expected conversion based on thermodynamics for the reaction of metal iron to wustite. This might be caused by the additives like chromium and copper oxides in the BIC iron oxide. It can therefore be concluded that, in general, the metal iron is initially oxidized to wustite followed by the oxidation of wustite to magnetite. A low reduction degree of the iron oxide is calculated $\left(\alpha\left(\mathrm{Fe}_{3} \mathrm{O}_{4}-\mathrm{Fe}\right)=15.3\right.$ $\%$ ), so metal iron is not expected. Because of this low conversion, it is likely that metal iron is formed on the surface while unreacted $\mathrm{Fe}_{3} \mathrm{O}_{4}$ is still present in the centre of the particle. The temperature rises above the set-point after the oxidation is started. During the oxidation of wustite an increase of $10{ }^{\circ} \mathrm{C}$ above the set-point is found. 
Table 3.6: Equilibrium oxidation data $\mathrm{T}=810^{\circ} \mathrm{C}$.

\begin{tabular}{|c|c|}
\hline Reaction & $\zeta_{\mathrm{H}_{2} \mathrm{O}}$ \\
\hline $3.17 \mathrm{Fe}_{0.95} \mathrm{O}(\mathrm{s})+0.83 \mathrm{H}_{2} \mathrm{O} \leftrightarrow \mathrm{Fe}_{3} \mathrm{O}_{4}(\mathrm{~s})+0.83 \mathrm{H}_{2}$ & $40.7 \%$ \\
\hline $\mathrm{Fe}(\mathrm{s})+\mathrm{H}_{2} \mathrm{O} \quad \leftrightarrow \mathrm{FeO}(\mathrm{s})+\mathrm{H}_{2}$ & $66.3 \%$ \\
\hline
\end{tabular}

After analyzing the first two redox cycles it is observed that the reduction is slow at an R-ratio ( $\mathrm{kg} \mathrm{Fe}_{3} \mathrm{O}_{4} / \mathrm{kg}$ pyrolysis oil) below 15 . Therefore subsequent redox cycles with fresh material are performed until a ratio of minimum 15 is obtained. In these experiments carbon deposition is lower: on average $11 \%$ of the total carbon input (from $100 \mathrm{~g}$ of oil) .

\subsubsection{Gasification of ethanol over an iron oxide bed}

Reduction of the BIC iron oxide is also performed with ethanol. High carbon to gas conversions are obtained $\left(\mathrm{C}_{\text {togas }}=99.1 \%\right)$. Now, with the presence of an oxygen source (the iron oxide), it is possible to completely gasify the ethanol to the gas phase. When BIC iron oxide is used a $\mathrm{C}_{\mathrm{x}} \mathrm{H}_{\mathrm{y}}$ production of $0.20 \mathrm{Nm}^{3} / \mathrm{kg}$ ethanol (of which approximately $0.18 \mathrm{Nm}^{3} / \mathrm{kg}$ ethanol $\mathrm{CH}_{4}$ and $0.02 \mathrm{Nm}^{3} / \mathrm{kg}$ ethanol $\mathrm{C}_{2}^{+}$) is obtained, while over the inert sand bed a production of $0.28 \mathrm{Nm}^{3} / \mathrm{kg}$ ethanol $\mathrm{CH}_{4}$ and $0.08 \mathrm{C}_{2}^{+}$ $\mathrm{Nm}^{3} / \mathrm{kg}$ ethanol is found. The reduction reactions that take place increase the $\mathrm{CO}_{2}$ and $\mathrm{H}_{2} \mathrm{O}$ concentration in the gas phase at the surface of the BIC iron oxide and enables steam and dry reforming of methane and other hydrocarbons.

\subsubsection{BF iron oxide}

A similar redox experiment as in the previous paragraph is conducted with BF and BF I iron oxide. Although the composition of these two iron oxides is similar (Table 3.2), a different reduction behavior is observed.

Table 3.7: Gas products $\left(\mathrm{Nm}^{3} / \mathrm{kg}\right.$ dry pyrolysis oil) obtained in a redox cycle with $\mathrm{BF}$ iron oxide $\left(M_{\text {bed }}=1.5 \mathrm{~kg}, \mathrm{~T}_{\text {reduction }}=\mathbf{7 8 0}{ }^{\circ} \mathrm{C}\right)$.

\begin{tabular}{lllll}
\hline & & RED (I) & RED (II) & OX \\
\hline $\mathrm{H}_{2}$ & $\left(\mathrm{Nm}^{3} / \mathrm{kg}\right.$ dry oil $)$ & 0.20 & & 0.25 \\
$\mathrm{CO}$ & $\left(\mathrm{Nm}^{3} / \mathrm{kg}\right.$ dry oil $)$ & 0.33 & 0.03 & 0.003 \\
$\mathrm{CO}_{2}$ & $\left(\mathrm{Nm}^{3} / \mathrm{kg}\right.$ dry oil $)$ & 0.11 & 0.04 & 0.011 \\
$\mathrm{C}_{\mathrm{x}} \mathrm{H}_{\mathrm{y}}$ & $\left(\mathrm{Nm}^{3} / \mathrm{kg}\right.$ dry oil $)$ & 0.18 & & - \\
\hline
\end{tabular}


The composition of the gas when BF iron oxide is reduced is shown in Table 3.7. The hydrogen produced in the oxidation is $0.25 \mathrm{Nm}^{3} / \mathrm{kg}$ dry pyrolysis oil (purity of $98.1 \mathrm{vol} \%$ ).

The gas products obtained during a redox cycle with $\mathrm{BF}$ iron oxide $\mathrm{I}$ are shown in Table 3.8 The $\mathrm{CO}_{2}$ production is low and the conversion of carbonaceous compounds in the second reduction step is close to zero. These two observations indicate that the reduction is very slow with BF I iron oxide.

Table 3.8: Gas products $\left(\mathrm{Nm}^{3} / \mathrm{kg}\right.$ dry pyrolysis oil) obtained in a redox cycle with $\mathrm{BF}$ I iron oxide $\left(M_{\text {bed }}=1.7 \mathrm{~kg}, T_{\text {reduction }}=780^{\circ} \mathrm{C}\right)$.

\begin{tabular}{lllll}
\hline & & RED (I) & RED (II) & OX \\
\hline $\mathrm{H}_{2}$ & $\left(\mathrm{Nm}^{3} / \mathrm{kg}\right.$ dry oil $)$ & 0.16 & - & 0.17 \\
$\mathrm{CO}$ & $\left(\mathrm{Nm}^{3} / \mathrm{kg}\right.$ dry oil $)$ & 0.34 & 0.005 & 0.02 \\
$\mathrm{CO}_{2}$ & $\left(\mathrm{Nm}^{3} / \mathrm{kg}\right.$ dry oil $)$ & 0.05 & 0.003 & 0.05 \\
$\mathrm{C}_{\mathrm{x}} \mathrm{H}_{\mathrm{y}}$ & $\left(\mathrm{Nm}^{3} / \mathrm{kg}\right.$ dry oil $)$ & 0.18 & - & - \\
\hline
\end{tabular}

The hydrogen production in the oxidation with BF I iron oxide is $0.17 \mathrm{Nm} 3 / \mathrm{kg}$ dry oil. However $0.12 \mathrm{Nm}^{3} / \mathrm{kg}$ dry oil from this hydrogen is produced from the reaction of steam with the carbonaceous deposits instead of the oxidation of iron oxide, resulting in an impure hydrogen product gas $\left(68.6 \mathrm{vol} \% \mathrm{H}_{2}, 23.0 \mathrm{vol} \% \mathrm{CO}_{2}\right.$ and 8.4 vol \% $\mathrm{CO}$ ). With $\mathrm{BF}$ I iron oxide only a small fraction of the particle is participating in the reduction and further reduction is extremely slow. Probably the high silica concentration in this iron oxide slows down the reduction rate. Silicon is a non-metal which can inhibit the migration of ions in the bulk material and the formation of iron silicate during the reduction course may reduce porosity [18].

\subsubsection{Repeated cycling}

To investigate the deactivation of the iron oxides, several cycles are performed with the iron oxide ( 13 cycles with BIC \& 4 cycles with BF). Figure 3.7 and 3.8 show the momentary $\zeta_{\mathrm{O} \text { to gas }}(\mathrm{t})$ during the pyrolysis oil injection as a function of the amount of oil injected $(1 / \mathrm{R}(\mathrm{t}))$. 


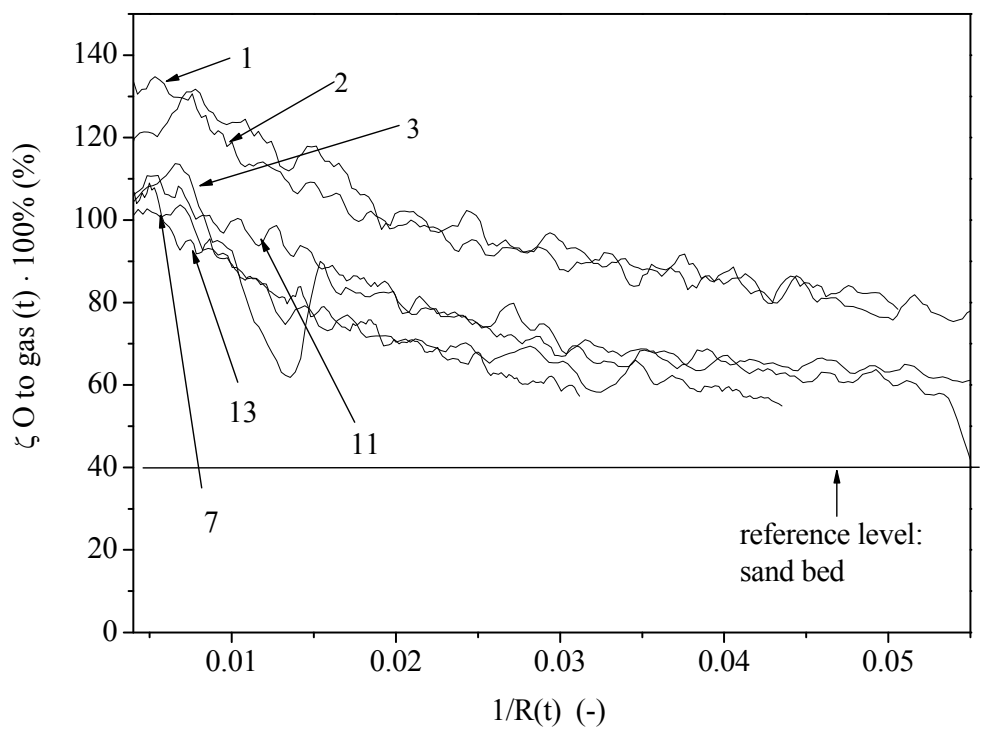

Figure 3.7: $\zeta_{\mathrm{O}}$ to gas versus 1/R(t) for repeated cycling of BIC iron oxide during reduction. In all experiments the reduction temperature is in the range of $745-755{ }^{\circ} \mathrm{C}$. The $1 / \mathrm{R}(\mathrm{t})$ on the $\mathrm{x}$-axis represents the increasing oil: $\mathrm{Fe}_{3} \mathrm{O}_{4}$ ratio during oil injection. The horizontal line represents a reference for oil gasification over an inert sand bed obtained at $800{ }^{\circ} \mathrm{C}$.

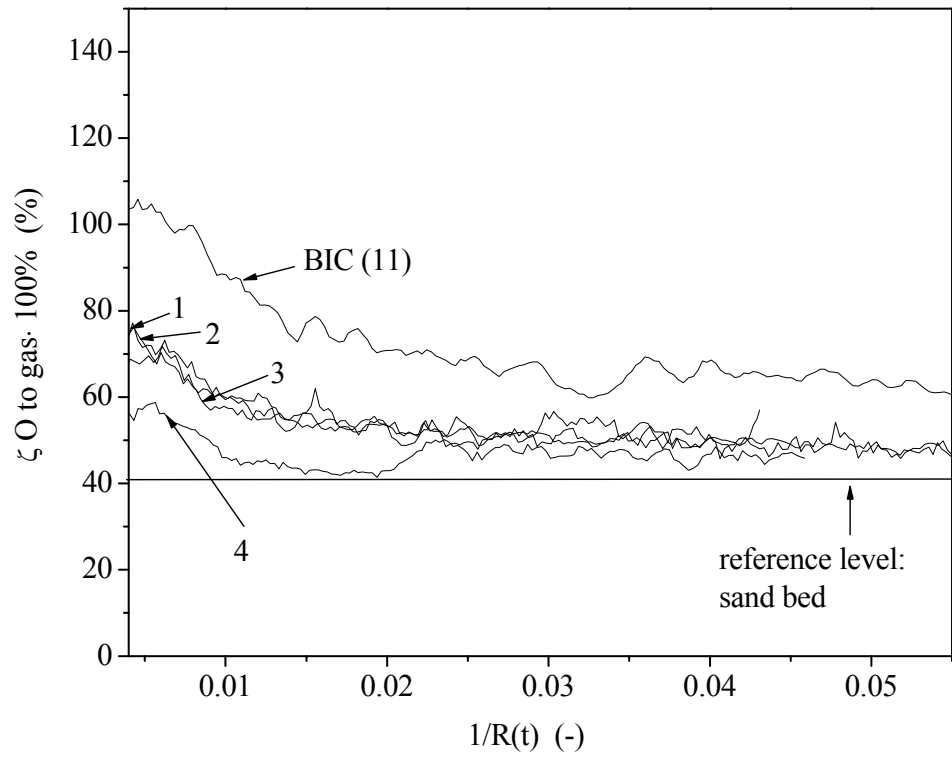

Figure 3.8: $\zeta_{0}$ to gas versus $1 / R(t)$ for repeated cycling of BF iron oxide compared to BIC iron oxide during reduction. In all experiments the reduction temperature was in the range of $745-755{ }^{\circ} \mathrm{C}$. The $1 / \mathrm{R}(\mathrm{t})$ on the $\mathrm{x}$-axis represents the increasing oil: $\mathrm{Fe}_{3} \mathrm{O}_{4}$ ratio during oil injection. The horizontal line represents a reference for oil gasification over an inert sand bed obtained at $800{ }^{\circ} \mathrm{C}$. 
Clearly at similar temperatures, the reduction ability of BF iron oxide is lower than that of BIC iron oxide. This could be caused by additives in the BIC iron oxide which facilitate the reduction rate of the iron oxide. Furthermore the gases formed from the oil during reduction with $\mathrm{BIC}$ and $\mathrm{BF}$ iron oxide differ substantially. The BIC iron oxide, as indicated in the previous paragraph, clearly showed an activity in catalyzing reforming reactions of $\mathrm{C}_{\mathrm{x}} \mathrm{H}_{\mathrm{y}}$, resulting in an increased formation of $\mathrm{H}_{2}$ and $\mathrm{CO}$. This is not the case for tests with BF iron oxide in which a gas composition similar to gasified oil over the sand bed is obtained. The results of a typical redox cycle with BF iron oxide compared to results obtained with sand are presented in Table 3.9. The high $\mathrm{CO} / \mathrm{CO}_{2}$ ratio of 3 indicates that not the full reduction potential of the oil is used.

Table 3.9: Gas products from redox cycle (first cycle with BF I iron oxide) with $100 \mathrm{~g}$ pyrolysis oil and $1.7 \mathrm{~kg} \mathrm{Fe}_{3} \mathrm{O}_{4}$. The gas products obtained with the cracking of the oil over a sand bed at $810{ }^{\circ} \mathrm{C}$ is also presented.

\begin{tabular}{lllll}
\hline & $\mathrm{BF}$ I & & \multirow{2}{*}{ Sand } \\
\cline { 2 - 4 } & $\operatorname{Red}(\mathrm{I})$ & $\mathrm{Red}(\mathrm{II})$ & $\mathrm{Ox}$ & \\
\hline Temperature & 780 & 800 & 820 & \\
\hline $\begin{array}{l}\text { Total average gas production } \\
\left(\mathrm{Nm}^{3} / \mathrm{kg} \text { dry-pyrolysis oil }\right)\end{array}$ & & & & 0.20 \\
$\mathrm{H}_{2}$ & 0.20 & & 0.25 & 0.35 \\
$\mathrm{CO}$ & 0.33 & 0.03 & 0.003 & 0.04 \\
$\mathrm{CO}_{2}$ & 0.11 & 0.04 & 0.01 & 0.12 \\
$\mathrm{CH}_{4}$ & 0.14 & - & - & 0.05 \\
$\mathrm{C}_{2}^{+}$ & 0.05 & - & - & 58.4 \\
$\zeta_{\mathrm{C} \text { to gas }}$ & 57.1 & & & \\
$\zeta_{\mathrm{C} \text { total }}-\zeta_{\mathrm{C} \text { to gas }}$ & & 6.7 & & \\
$\mathrm{Other}_{\zeta_{\mathrm{H}_{2} \mathrm{O}} \text { max }}$ & & & \\
$\alpha\left(\mathrm{Fe} \mathrm{O}_{4}-\mathrm{Fe}\right)$ & $22 \%$ & \\
\hline
\end{tabular}

For both iron oxides the amount of oxygen transported to the gas phase ( $\zeta \mathrm{O}$ to gas $(\mathrm{t}))$ decreases over the subsequent cycles and consequently the reduction rate during these cycles is decreasing. Most of the deactivation of the BIC iron oxide takes place in the first two redox cycles. The patterns of cycle 7,11 and 13 of BIC iron oxide are similar indicating that the activity of the iron oxide approaches a steady 
state. In all cycles for both iron oxides the reduction rate is optimal at $1 / \mathrm{R}(\mathrm{t})$ values $<$ 0.01. Apparently, the reduction rate is high when the particle consists of $\mathrm{Fe}_{3} \mathrm{O}_{4}$ but decreases when the particle is only partly reduced. This has also been acknowledged in literature [19]. At high $1 / \mathrm{R}(\mathrm{t})$ values $(>+/-0.04)$ most of the gases produced by gasification of pyrolysis oil pass through the bed unconverted. This can be concluded because above a $1 / \mathrm{R}(\mathrm{t})$ value of 0.04 about the same amount of oxygen is found in the gas phase as in the pyrolysis oil gasification experiments over the fluidized sand bed (Figure 3.7 and 3.8).

The difference in activity between BF and BIC material is also evident from the steam conversion in the oxidation step. Figure 3.9 shows that the oxidation activity of $\mathrm{BF}$ iron oxide is lower than the BIC iron oxide. The equilibrium value of $40.7 \%$ steam conversion at $810^{\circ} \mathrm{C}$ is almost reached with the $\mathrm{BIC}$ iron oxide (Table 3.6). Both iron oxides show a steady steam conversion over a wide range of $1 / R_{o x}(t)$. Figure 3.9 also shows that, apparently, carbon remained on the iron oxide after the reduction resulting in a water-gas reaction $\left(\zeta_{\mathrm{H} 2 \mathrm{O} \text { reacted with } \mathrm{C}}\right)$ in the oxidation step.

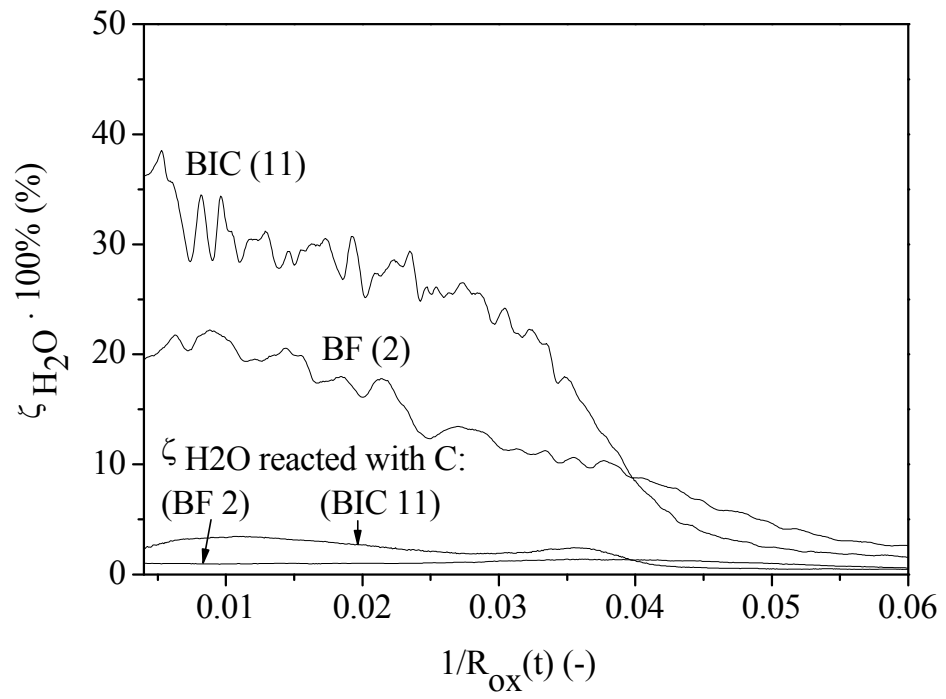

Figure 3.9: Total momentary $\mathrm{H}_{2} \mathrm{O}$ conversion during oxidation at $\mathrm{T}=810{ }^{\circ} \mathrm{C}$ of reduced $\mathrm{BIC}$ and $\mathrm{BF}$ iron oxide. $\zeta \mathrm{H}_{2} \mathrm{O}$ reacted with $\mathrm{C}$ of $\mathrm{BF}$ and $\mathrm{BIC}$ is the conversion of $\mathrm{H}_{2} \mathrm{O}$ by the reaction with deposited carbon.

The purity of the hydrogen produced in the oxidation step depends on the conversion of deposited carbon in the second phase of the reduction step. The 
reduction of iron oxide with carbon deposits can take place above temperatures of 700 ${ }^{\circ} \mathrm{C}$. Complete conversion of the carbon deposits depends on temperature, amount of carbon deposits, iron oxide material and the time between the end of oil injection and start of the oxidation. A high purity hydrogen (99 vol \%) can be obtained when these three factors are taken into account.

\subsubsection{Deactivation}

During the redox cycles with the BIC iron oxides a deactivation is observed in the first 3 cycles, which is less severe in the case for the BF iron oxide. BET analysis of the BIC iron oxide shows a substantial decrease in surface area of the BIC particles as given in Table 3.10. A worsening of the surface area of $\mathrm{BIC}$ iron oxide is observed after a reduction with $\mathrm{H}_{2}$ of fresh material $\left(\mathrm{Fe}_{2} \mathrm{O}_{3}\right)$ to metal iron. Therefore the decrease in surface area observed when redox cycles are performed could have partly been caused by the first reduction of fresh material to a lower oxide.

Table 3.10: BET surface area analysis of BIC iron oxide after reduction with $\mathrm{H}_{2}$ and redox cycles with pyrolysis oil.

\begin{tabular}{lll}
\hline & $\begin{array}{l}\text { BET analysis } \\
\left(\mathrm{m}^{2} / \mathrm{g}\right)\end{array}$ & $\begin{array}{l}\text { Fraction } \\
\mathrm{d}_{\mathrm{p}}>225 \mu \mathrm{m}\end{array}$ \\
\hline $\mathrm{Fe}_{2} \mathrm{O}_{3}\left(\mathrm{~d}_{\mathrm{p}}=1.0 \mathrm{~mm}\right)$ & 31.12 & $100 \%$ \\
$\mathrm{Fe}\left(\mathrm{Fe}_{2} \mathrm{O}_{3}\right.$ fully reduced with $\mathrm{H}_{2}$ at $\left.800{ }^{\circ} \mathrm{C}\right)$ & 4.67 & $100 \%$ \\
After 3 cycles & 0.76 & $51 \%$ \\
After 14 cycles & 0.37 & \\
\hline
\end{tabular}

It is found that after 3 cycles the pore structure, which is accessible for the evaluation gas, has deteriorated. Only the outer surface of the particles seems to contribute to the BET surface area. The decrease in surface area between the $3^{\text {th }}$ and $14^{\text {th }}$ cycle is less severe. The activity of the BF iron oxide is also influenced by the performed redox cycles. The BF iron oxide has a lower initial surface area (Table 3.2) and therefore further decrease is probably slower than in the case with the BIC iron oxide. From the oxygen balances during the injection of the pyrolysis oil it is found that high $\mathrm{Fe}_{3} \mathrm{O}_{4}$ /pyrolysis oil ratios are optimum. This optimum ratio is increased after more redox cycles with pyrolysis oil. So the time, in which a high reduction rate is anticipated, decreases when the iron oxide deactivates. A high reduction rate is expected at the start of the reduction when the particle consists of $\mathrm{Fe}_{3} \mathrm{O}_{4}$. When the outer surface of the particle is reduced a boundary layer with reduced species is 
formed, which most likely shows a slowing down of the reduction reaction $[18,20]$. Probably already in the first cycle boundary layer formation has an effect on the reduction rate, but this effect is enhanced with repeated cycling. This is observed for both the reduction with pyrolysis oil and ethanol in which very little carbon formation on the surface is observed after injection. This also confirms that the decrease in rate is probably caused by changes in the iron oxide structure and not by the formation of carbon on the surface. Due to the wustite boundary layer the reaction rate is slowed down and can be limited by diffusion processes in the solid particles [21-23].

SEM pictures are taken to study the outer surface of the particles. Figure $3.10 \mathrm{~A}$ shows the outer surface of an unused BIC iron oxide particle, where a high surface area is observed. In Figure 3.10B the surface of deactivated BIC iron oxide area after 3 redox cycles is shown. A less porous structure is observed as expected from the BET analysis. Figure 3.10C shows a sintered structure with greatly enhanced grain size that is obtained after 14 redox cycles. The BIC material contains some copper oxide $(2.7 \mathrm{wt} \%$ ) which are seen to form crystals on the surface after 14 cycles (Figure 3.10C). Copper oxide is expected to be more reactive for reduction from a thermodynamic point of view. This copper oxide on the surface might have an effect on the high reduction rate at the start of the reduction reaction [12]. 


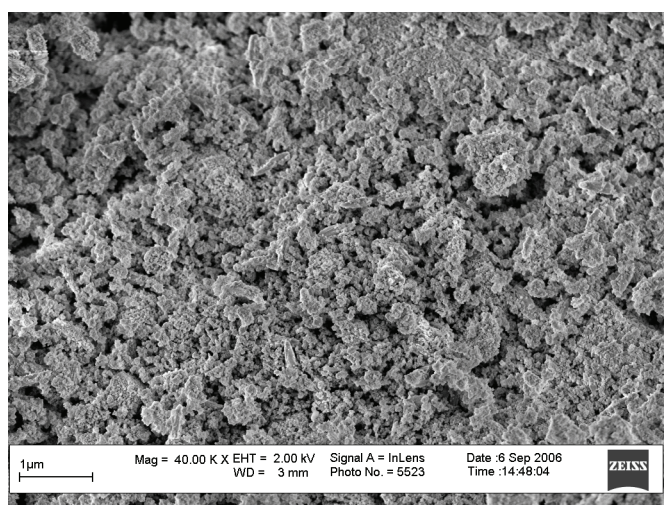

A

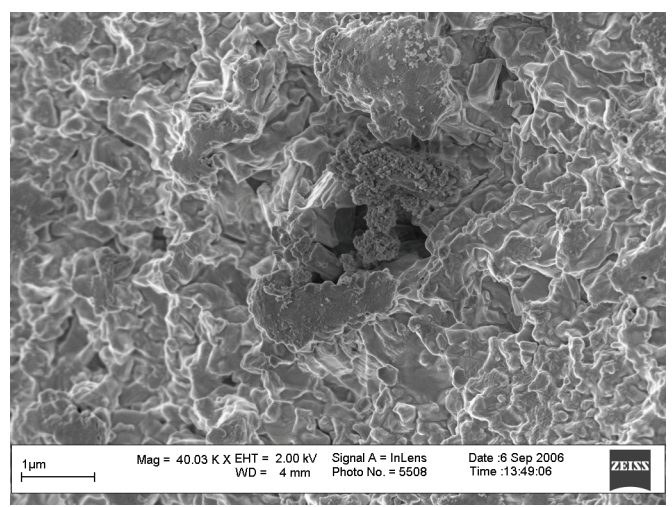

B

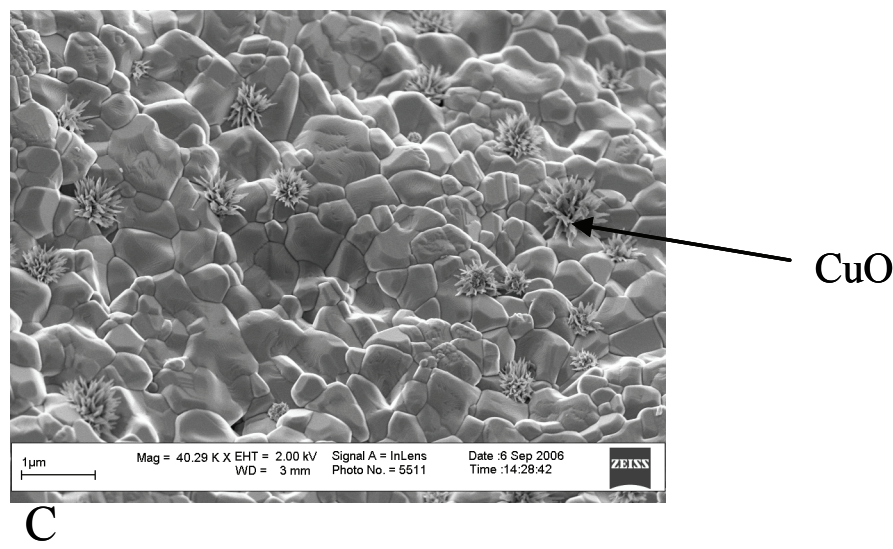

Figure 3.10: Surface area of BIC iron oxide. A: fresh iron oxide $\left(\mathrm{Fe}_{2} \mathrm{O}_{3}\right)$. B: after 3 redox cycles $\left(\mathrm{Fe}_{3} \mathrm{O}_{4}\right) \mathrm{C}$ : after 14 redox cycles $\left(\mathrm{Fe}_{3} \mathrm{O}_{4}\right)$, copper oxide crystals are formed on the surface.

An interesting point is the rapid morphological changes in the porous iron particles. Intensive recycling giving rise to substantial internal self diffusion in the iron oxide seems to speed up densification and sintering. This internal morphological change affects the availability of iron oxide for the steam-iron process but not to the extent of the BET surface area reduction. Large cracks in the particle are observed in the fresh material and are still present in the material after 14 cycles (Figure 3.11). These cracks make it possible for gases to migrate in and out of the particles that could explain the relatively high activity after deactivation. 


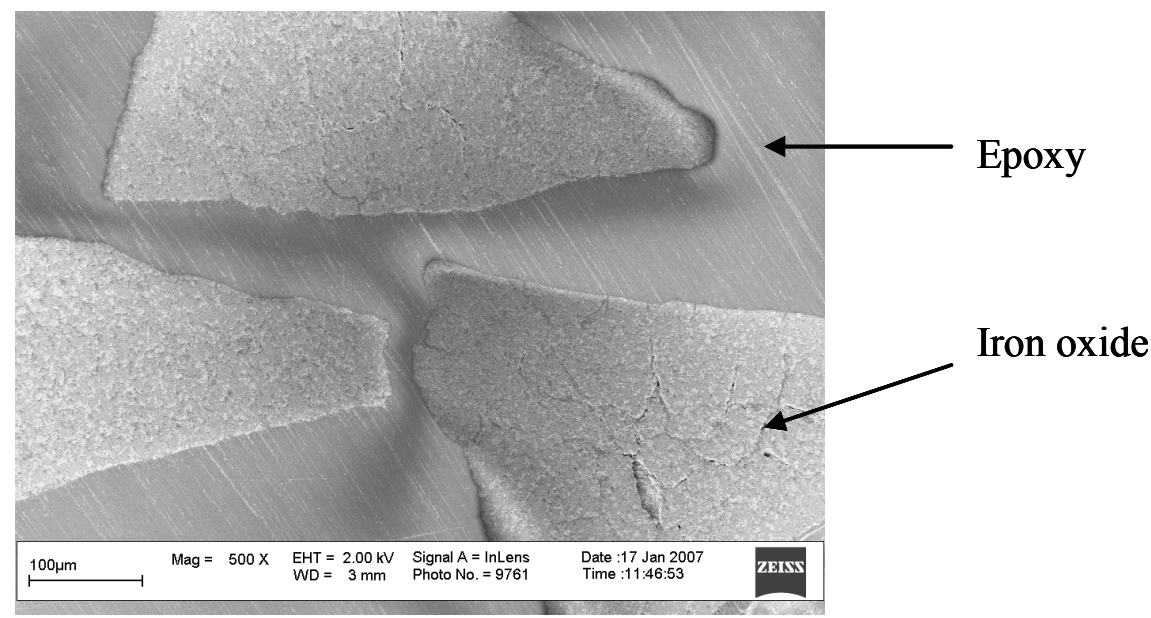

Figure 3.11: Cross section $\mathrm{BIC}$ iron oxide after 14 redox cycles $\left(\mathrm{Fe}_{3} \mathrm{O}_{4}\right)$.

Deactivation caused by the sintering of the surface during repeated cycling is also observed by other researchers. It is reported that the stability could be improved by using additives like $\mathrm{Al}, \mathrm{Mo}, \mathrm{Ce}$ and $\mathrm{Cr}[24,25]$ or quartz [26] in the iron oxide. Furthermore, if only the outer layer of the iron oxide is highly reactive, iron oxide can be deposited on a porous carrier, which could prevent severe sintering of the iron oxide particle.

Other factors, like the swelling and shrinking of the iron oxide due to the change of the crystal structure, agglomeration and break-up of the particles play a role in the deactivation of the particles in the fluidized bed set-up.

\subsubsection{Hydrogen production and potential}

The hydrogen production in the redox cycle is measured from the results obtained in the experimental set-up with BF and BIC iron oxides. It was already observed that the reduction reaction is very rapid and slows down when a small part of the particle is reduced. Therefore experiments with $\mathrm{R}$ values of 150 down to 15 are performed (Figure 3.12). From this figure an internal circulation $(\mathrm{kg} / \mathrm{s}) /$ feed rate $(\mathrm{kg} / \mathrm{s})$ ratio of 100 for both iron oxides seems optimum for the conversion of pyrolysis oil to hydrogen. This ratio is comparable to conventional CFB biomass gasification, where sand is circulated for heat transfer. In this process a circulation rate $(\mathrm{R})$ of 50 sand $(\mathrm{kg} / \mathrm{s}) /$ dry biomass $(\mathrm{kg} / \mathrm{s})$ is appropriate [27]. 


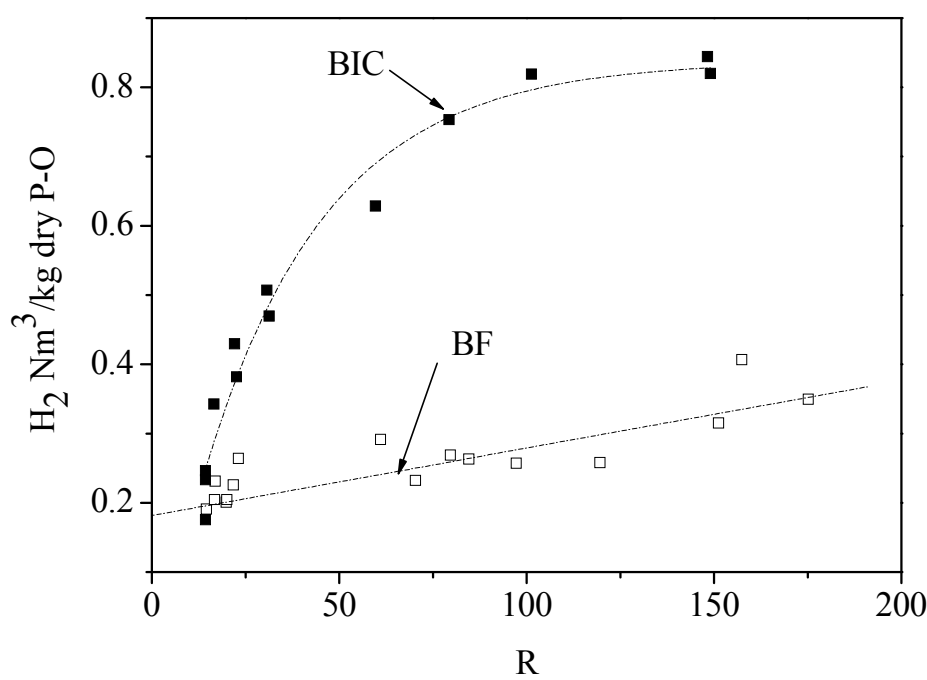

Figure 3.12: Hydrogen produced in the oxidation step from oxidized iron oxide with steam (corrected for water gas reaction). After initial reduction with an $\mathbf{R}$ value between 15 and 100 at temperatures between 810-750 ${ }^{\circ} \mathrm{C}$. Deactivated $\mathrm{BIC}$ iron oxide is used in this graph (cycle number 5-13) and BF iron oxide cycle number (1-15).

The highest hydrogen product (from the oxidation) that is obtained with the BF iron oxide is $0.35 \mathrm{H}_{2} \mathrm{Nm}^{3} / \mathrm{kg}$ dry pyrolysis oil, which comes close to the expected value of $0.37 \mathrm{H}_{2} \mathrm{Nm}^{3} / \mathrm{kg}$ dry pyrolysis oil, which is calculated from the gas products obtained when pyrolysis oil is gasified over the sand bed at $810^{\circ} \mathrm{C}$ (Figure 3.5). It can therefore be concluded that the conversion of pyrolysis oil to reducing gases is not influenced to a large extend by the BF iron oxide. The gas produced in the reduction step still has a reducing capacity even at high $\mathrm{R}$ values (Table 3.11). This is found by comparing the $\mathrm{CO} / \mathrm{CO}_{2}$ ratio obtained with the expected equilibrium value. If this remaining $\mathrm{CO}$ would also be used for reduction an additional hydrogen production of $0.07 \mathrm{Nm}^{3} / \mathrm{kg}$ dry pyrolysis oil could be obtained.

The BIC iron oxide has a twice as high hydrogen production at high $\mathrm{R}$ values than expected from the calculated hydrogen production from gasified pyrolysis oil. This is caused by the catalytic activity of the iron oxide for reforming reactions, resulting in more $\mathrm{H}_{2}$ and $\mathrm{CO}$ during the gasification of the pyrolysis oil. The highest hydrogen production of $0.84 \mathrm{Nm}^{3} / \mathrm{kg}$ dry pyrolysis oil in the set-up is obtained with the BIC iron oxide and an $\mathrm{R}$ value of 100 or higher. The found $\mathrm{CO} / \mathrm{CO}_{2}$ ratio of 0.57 in the reduction step at high $\mathrm{R}$ values is lower than the equilibrium value of 0.65 at $780{ }^{\circ} \mathrm{C}$ (Table 3.11). This shows that a high conversion of $\mathrm{CO}$ in the reduction is 
obtained. A lower $\mathrm{CO} / \mathrm{CO}_{2}$ value found than expected from the thermodynamic data and reaction between wustite and magnetite might indicate that the additives in the BIC iron oxide (mainly copper and chromium oxide) probably has an effect in the established $\mathrm{CO} / \mathrm{CO}_{2}$ ratio. The maximum attainable hydrogen production from pyrolysis oil with the steam-iron process can be calculated from thermodynamics: this value is $1.5 \mathrm{Nm}^{3} / \mathrm{kg}$ dry pyrolysis oil at $800{ }^{\circ} \mathrm{C}$ (Chapter 2). In this calculation, first the equilibrium between pyrolysis oil (in the form of $\mathrm{C}_{\mathrm{x}} \mathrm{H}_{\mathrm{y}} \mathrm{O}_{\mathrm{z}}$, Table 3.1) $\mathrm{Fe}_{3} \mathrm{O}_{4} / \mathrm{Fe}_{0.945} \mathrm{O}$ is calculated while assuming that there is an excess of $\mathrm{Fe}_{3} \mathrm{O}_{4}$ and that at equilibrium the following gases could be present: $\mathrm{CO}, \mathrm{CO}_{2}, \mathrm{CH}_{4}, \mathrm{H}_{2}$, and $\mathrm{H}_{2} \mathrm{O}$. This gives the amount of $\mathrm{Fe}_{0.945} \mathrm{O}$ formed per $\mathrm{kg}$ pyrolysis oil, on basis of which the amount of $\mathrm{H}_{2}$ is calculated by assuming complete conversion in the oxidation with steam to $\mathrm{Fe}_{3} \mathrm{O}_{4}$.

Table 3.11: Gas product of the gas products in a redox cycle with $\mathrm{BIC}$ and $\mathrm{BF}$ iron oxide with high $\mathrm{Fe}_{3} \mathrm{O}_{4} /$ oil (=R) ratio.

\begin{tabular}{|c|c|c|c|c|}
\hline & $\mathrm{BIC}$ & & $\mathrm{BF}$ & \\
\hline $\mathrm{R}$ & 148.3 & & 157.4 & \\
\hline \multirow[t]{2}{*}{$\mathrm{T}\left({ }^{\circ} \mathrm{C}\right)$} & 780 & & 795 & \\
\hline & Red & $\mathrm{Ox}$ & Red & Ox \\
\hline \multicolumn{5}{|l|}{$\begin{array}{l}\text { Gas product } \\
\left(\mathrm{Nm}^{3} / \mathrm{kg} \text { dry oil in }\right)\end{array}$} \\
\hline $\mathrm{H}_{2}$ & 0.32 & 0.84 & 0.22 & 0.43 \\
\hline $\mathrm{C}_{\mathrm{x}} \mathrm{H}_{\mathrm{y}}$ & 0.05 & & 0.13 & \\
\hline $\mathrm{CO}$ & 0.26 & 0.002 & 0.27 & 0.002 \\
\hline $\mathrm{CO}_{2}$ & 0.46 & 0.005 & 0.26 & 0.008 \\
\hline $\mathrm{CO} / \mathrm{CO}_{2}(\mathrm{~mol} / \mathrm{mol})$ & 0.57 & & 1.04 & \\
\hline \multicolumn{5}{|l|}{ Other } \\
\hline $\begin{array}{l}\mathrm{LHV} \text { gas product } \\
\left(\mathrm{MJ} / \mathrm{Nm}^{3} \text { gas product }\right)\end{array}$ & 7.8 & 10.6 & 11.7 & 10.5 \\
\hline $\begin{array}{l}\eta \text { based on LHV } \\
\text { (MJ gas produced/MJ oil in) }\end{array}$ & 0.38 & 0.40 & 0.46 & 0.20 \\
\hline$\alpha\left(\mathrm{Fe}_{3} \mathrm{O}_{4}-\mathrm{Fe}\right)$ & & 1.0 & & 0.5 \\
\hline
\end{tabular}




\subsection{Conclusions}

Pyrolysis oil is used successfully as a reducing agent in the steam-iron process. The most important findings from the experiments performed are listed below:

- A significant amount of relatively pure hydrogen can be produced in a redox cycle with iron oxides, next to a fuel gas. The use of a catalytic iron oxide resulted in an improved conversion of pyrolysis oil to pure hydrogen, due to the enhanced reforming of hydrocarbons in the reduction step.

- The reduction of the iron oxide with pyrolysis oil or ethanol is positively influenced by the catalytic reforming reactions taking place on the surface with the BIC iron oxide.

- Directly injecting pyrolysis oil in a fluidized bed of iron oxides has the particular advantage that deposited carbon on the iron oxides contributes to the reduction of iron oxides. Pure hydrogen can only be obtained when the reduction with this deposited carbon is completed.

- Overall performance of the process is optimal when thermodynamic equilibrium in the gas phase is obtained during reduction. This is achieved by increasing the iron oxide to pyrolysis oil ratio that corresponds to a high circulation rate of iron oxides and low conversion of the iron oxide particle. An additional advantage of a high circulation rate is an improved heat transport in the fluidized bed, needed for the cold pyrolysis oil injection during the endothermic reduction.

- Both BF and BIC iron oxide show potential to be used in the production of hydrogen from pyrolysis oil in the proposed concepts. The BF iron oxide is more suitable for a once-through concept. The BIC iron oxide can be used in a cycling process, though further improvements of the material should enhance the stability and activity.

- Deactivation of the iron oxide is observed, causing a decrease in reaction rate during reduction. Observed loss of surface area of the particles with BET and SEM analysis could partly explain this deactivation. 


\subsection{Nomenclature}

\begin{tabular}{|c|c|c|}
\hline$\Phi_{\mathrm{m}}$ & $(\mathrm{kg} / \mathrm{s})$ & Mass flow \\
\hline$\Phi_{\mathrm{v}}$ & $(\mathrm{Nl} / \mathrm{s})$ & Volumetric flow \\
\hline$\Phi$ & $(\mathrm{mol} / \mathrm{s})$ & Mol flow \\
\hline $\mathrm{f}$ & $(-)$ & Weight fraction \\
\hline $\mathrm{X}$ & $(-)$ & Mole fraction \\
\hline M & $(\mathrm{g} / \mathrm{mole})$ & Molecular weight \\
\hline $\mathrm{S}_{0}$ & (mole) & Amount of oxygen in iron oxide \\
\hline $\mathrm{u}_{\text {reactor }}$ & $(\mathrm{m} / \mathrm{s})$ & Gas velocity in the fluidized bed reactor \\
\hline $\mathrm{u}_{\mathrm{mf}}$ & $(\mathrm{m} / \mathrm{s})$ & Minimum fluidization velocity \\
\hline$\tau($ bed $)$ & (s) & $\begin{array}{l}\text { Residence time in the fluidized bed }\left(\mathrm{V}_{\text {bed }} \cdot \varepsilon_{\mathrm{mf}} /\left(\Phi_{\mathrm{v}, \text { in }}+\right.\right. \\
\left.\left.\Phi_{\mathrm{v}, \text { out }}\right) / 2\right)\end{array}$ \\
\hline$\tau_{\mathrm{d}}$ & (s) & Dead time \\
\hline $\mathrm{M}$ bed & $(\mathrm{kg})$ & Mass of the bed material \\
\hline V bed & (m3) & Volume of the bed material \\
\hline L bed & (m) & Bed height \\
\hline$\rho$ & $(\mathrm{kg} / \mathrm{m} 3)$ & Density \\
\hline$d_{p}$ & $(\mu \mathrm{m})$ & Particle diameter \\
\hline$\zeta_{\mathrm{C} \text { to gas }}$ & $(-)$ & Conversion of carbon from the oil to the gas phase \\
\hline$\zeta_{\mathrm{C} \text { total }}$ & $(-)$ & $\begin{array}{l}\text { Conversion of carbon from the oil to the gas phase and } \\
\text { deposited on the bed material }\end{array}$ \\
\hline$\zeta_{\mathrm{H}_{2} \mathrm{O}}$ & $(-)$ & Conversion of steam during oxidation \\
\hline$\zeta_{\mathrm{H}_{2} \mathrm{O}} \max$ & $(-)$ & Highest conversion of steam during oxidation \\
\hline$\zeta_{\mathrm{H}_{2} \mathrm{O} \text { reacted with } \mathrm{C}}$ & $(-)$ & $\begin{array}{l}\text { Conversion of steam by the reaction of steam with } \\
\text { carbon }\end{array}$ \\
\hline$\alpha\left(\mathrm{Fe}_{3} \mathrm{O}_{4}-\mathrm{Fe}\right)$ & $(-)$ & Reduction degree of iron oxides \\
\hline $\mathrm{R}$ & $(-)$ & Mass ratio of iron oxide and oil \\
\hline $\mathrm{R}_{\mathrm{ox}}$ & $(-)$ & Mass ratio of iron oxide and steam \\
\hline$\eta$ & $(-)$ & $\begin{array}{l}\text { Energy efficiency calculated from the gas produced } \\
\text { during reduction or oxidation and the oil injected } \\
\text { (LHV MJ gas product/LHV MJ oil) }\end{array}$ \\
\hline $\mathrm{P}$ & $(\mathrm{Pa})$ & Pressure \\
\hline $\mathrm{R}$ & $(\mathrm{J} / \mathrm{molK})$ & Gas constant \\
\hline $\mathrm{T}$ & $(\mathrm{K})$ & Temperature \\
\hline$\Delta \mathrm{H}_{\mathrm{r}}^{\circ}$ & $(\mathrm{kJ} / \mathrm{mol})$ & Reaction enthalpy \\
\hline$\Delta \mathrm{G}_{\mathrm{r}}^{\mathrm{o}}$ & $(\mathrm{kJ} / \mathrm{mol})$ & Reaction Gibbs energy \\
\hline
\end{tabular}




\begin{tabular}{|ll|}
\hline Abbreviations & \\
\hline P-O & Pyrolysis oil \\
Subscript O & Oxygen \\
Subscript C & Carbon \\
\hline
\end{tabular}

\subsection{Literature}

1 Meyer, R.J., Wasserstoff. $8^{\text {th }}$ ed. Gmelins Handbuch der Anorganischen Chemie. Vol. 2, Weinheim, Bergstrasse, Verlag Chemie, GMBH. 1927.

2 Tarman, P.B. and R. Biljetina, 5 (1979) p. 114-116.

3 Tarman, P.B., $5^{\text {th }}$ Synthesis pipeline gas symposium. Chicago, IL: Institute of Gas Technology, 1973.

4 Fukase, S. and T. Suzuka, Canadian Journal of Chemical Engineering, 72 (1994) p. 272-278.

5 Fukase, S. and T. Suzuka, Applied Catalysis A, 100 (1993) p. 1-17.

6 Hacker, V., Journal of power sources, 118 (2003) p. 311-314.

7 Hacker, V., et al., Journal of power sources, 86 (2000) p. 531-535.

8 Mattisson, T. and A. Lyngfelt. Second nordic mini symposium on carbon dioxide capture and storage, Götenborg, 2001.

9 Garcia, L., et al., Applied Catalysis A: General, 201 (2000) p. 225-239.

10 Panigrahi, S., et al., Energy \& Fuels, 17 (2003) p. 637-642.

11 Mattisson, T., A. Lyngfelta, and P. Chob, Fuel, 80 (2001) p. 1953-1962.

12 Takenaka, S. and K. Otsuka, Energy \& Fuels, 18 (2004) p. 820-829.

13 Hacker, V., et al.,. 71 (1998) p. 226-230.

14 Malcolm, W. and J. Chase, NIST-JANAF thermochemical tables. $4^{\text {th }}$ ed. Woodbury, NY, American Institute of Physics, 1998.

15 O. Levenspiel, D. Kunii, Fluidization Engineering, $2^{\text {nd }}$ ed., ButterworthHeineman, Boston, 1991.

16 Van Rossum, G., S.R.A. Kersten, and W.P.M. van Swaaij, Industrial \& Engineering Chemistry Research, 2007. Article in press.

17 Wornat, M.J., B.G. Porter, and N.Y.C. Yang, Energy \& Fuels, 8 (1994) p. 1131-1142.

18 L. von Bogdandy, H.-J. Engell, The Reduction of Iron Ores: Scientific Basis and Technology, Springer-Verlag, Berlin, 1971.

19 Guo, X., et al., Mettalurgical and Materials Transactions B,. 35B (2004) p. 517-522. 
20 Ullmann's Encyclopedia of Industrial Chemistry, 7th ed., John Wiley \& Sons, 2006.

21 Wiltowski, T., et al., Chemical Engineering and Processing, 44 (2005) p. 775783.

22 Fortini, A.J. and D.D. Perlmutter, AIChE Journal, 35(1989) p. 1245-1252.

23 Piotrowski, K., et al., International Journal of Hydrogen Energy, 2005.

24 Takenaka, S., et al., Journal of Catalysis, 228 (2004) p. 66-74.

25 Otsuka, K., et al., Journal of power sources, 122 (2003) p. 111-121.

26 Thaler, M., et al., International Journal of Hydrogen Energy, 31 (2006) p. 2025-2031.

27 Kersten, S.R.A., Biomass gasification in circulating fluidized beds. University of Twente, Enschede, 2002. 


\title{
Chapter 4
}

\section{Redox experiments with pyrolysis oil in the fluidized bed (Part II)}

\section{The effect of temperature and iron oxide conversion in the reduction on the hydrogen production}

\begin{abstract}
In the steam-iron process relatively pure hydrogen can be produced from pyrolysis oil in a redox cycle with iron oxides. Experiments in a fluidized bed showed that the hydrogen production from pyrolysis oil increases by increasing the temperature during reduction. The experimental hydrogen production at nearly 1000 ${ }^{\circ} \mathrm{C}$ with non-catalytic (blast furnace) and catalytic iron oxide (HT shift catalyst used in ammonia production process) is respectively 1.39 and $1.82 \mathrm{H}_{2} \mathrm{Nm}^{3} / \mathrm{kg}$ dry oil. However, this high hydrogen production could only be achieved when a low relative conversion ( $\alpha$ ) of the iron oxide in the reduction is maintained (about $7 \%$ ). It is found in all experiments that the reduction rate decreases strongly with increasing relative conversion of the iron oxide (at $800{ }^{\circ} \mathrm{C}$ the relative conversion rate $(\mathrm{d} \alpha / \mathrm{dt}$ ) decreases from $3.0 \cdot 10^{-4} \mathrm{~s}^{-1}$ at $\alpha\left(\mathrm{Fe}_{3} \mathrm{O}_{4}-\mathrm{Fe}_{1-\delta} \mathrm{O}\right)=0.6 \%$ to $8.8 \cdot 10^{-6} \mathrm{~s}^{-1}$ at $\alpha\left(\mathrm{Fe}_{3} \mathrm{O}_{4}-\mathrm{Fe}_{1-\delta} \mathrm{O}\right)=10.0$ $\%$. The gasification of pyrolysis oil over an iron oxide bed results in an increased carbon to gas conversion compared to gasification over a sand bed. Near complete gasification of oil is achieved when temperatures above $900{ }^{\circ} \mathrm{C}$ are applied in the fluidized bed set-up containing iron oxide. A lumped reaction path scheme is proposed for char formation in pyrolysis oil gasification.
\end{abstract}




\subsection{Introduction}

In the previous chapter redox experiments with pyrolysis oil and steam in a fluidized bed are described. To obtain sufficiently pure hydrogen, a complete redox cycle consists of three steps instead of two in the experimental set-up. This second step (stripping section) can be minimized or omitted in the process if the purity of hydrogen can be relaxed. It was concluded that with increasing temperatures the oil to gas conversion increases and that more $\mathrm{CO}$ and $\mathrm{H}_{2}$ are produced at the expense of hydrocarbons and $\mathrm{H}_{2} \mathrm{O}$. Both the increased oil to gas conversion and the changed gas composition improved the reducing capacity of the oil, especially at temperatures above $850^{\circ} \mathrm{C}$. Both the endothermic gasification of pyrolysis oil and the iron oxide reduction are expected to be more effective with increasing temperature (based on thermodynamics). On the other hand, the steam conversion in the oxidation will decrease with increasing temperature, caused by the decrease of the equilibrium steam conversion with increasing temperature. The increased steam requirements for the oxidation with increasing temperature will have a negative effect on the total energy balance of the process, when the hydrogen is separated from the product stream by condensation of the steam fraction (Chapter 2 and Chapter 7).

In this chapter the expected higher hydrogen production from pyrolysis oil at higher temperatures will be tested by conducting several redox cycles at different temperatures between $800-1000{ }^{\circ} \mathrm{C}$ in the fluidized bed set-up. Besides temperature, the effect of the conversion degree of the iron oxide on the gaseous products in both reduction and oxidation is measured.

To minimize the effect of structural changes of the iron oxide on the experimental results a deactivated material, which has already been used in several redox cycles, is applied. It has been found in a our previous work that strong deactivation of the catalytic iron oxide takes place in the first redox cycles, where after it reaches a more steady performance (Chapter 3 and Chapter 6).

\subsection{Model for the interpretation of the reduction}

The reduction reaction that takes place in the experimental set-up will be analyzed by a simplified gas-solid reaction model. The reduction is performed with pyrolysis oil, from which different reducing compounds can be obtained. To simplify 
the reduction reaction in the model it will be assumed that the reduction is taking place with only one gaseous component, named A. The quantity of this gaseous compound A in the model is the sum of the experimentally produced $\mathrm{CO}$ and $\mathrm{H}_{2}$ from the gasification of pyrolysis oil.

$\mathrm{Fe}_{3} \mathrm{O}_{4}+\mathrm{A}(\mathrm{g}) \leftrightarrow 3 \mathrm{Fe}_{1-\delta} \mathrm{O}+\mathrm{P}(\mathrm{g})$

The amount of $\mathrm{P}$ formed this way represents the total amount of $\mathrm{CO}_{2}$ and $\mathrm{H}_{2} \mathrm{O}$ formed after reduction. The gas solid reaction can be described by many different gassolid particle models, which can be found in literature [1-3]. The appropriate particle model depends on the material properties, like the porosity of the solid and the external conditions applied. In general the overall reaction rate includes the mass transport of the gaseous reactants and products to and from the reaction surface and the chemical reaction itself, which takes place at the reaction surface. The rate of these processes depends on the conversion degree of the material applied. For example a solid product layer may grow upon reduction resulting in an increased boundary layer through which diffusion of the reactants/products to the reaction site needs to take place. Also the available surface at which the reaction can take place can decrease with increasing conversion degree of the particle/grain (shrinking core model/grainy pellet model). These phenomena can all be included in the overall conversion rate, which can be described as:

$$
\frac{\mathrm{d} \alpha}{\mathrm{dt}}=\mathrm{k}(\mathrm{T}) \cdot \mathrm{f}_{1}(\alpha) \cdot \mathrm{f}_{2}(\text { gas })
$$

in which $\mathrm{k}(\mathrm{T})$ is the temperature dependent rate constant, $\mathrm{f}_{1}(\alpha)$ is a function which describes the effect of the relative conversion $(\alpha)$ on the reduction rate and $f_{2}($ gas $)$ is a function describing the effect of the gas concentration on the conversion rate. In most gas solid reactions the order of the gas concentration is 1 . In general the reversible reduction can be described as:

$$
\alpha<\alpha_{\max } \quad \frac{\mathrm{d} \alpha}{\mathrm{dt}}=\mathrm{k}(\mathrm{T}) \cdot\left(1-\frac{\alpha}{\alpha_{\max }}\right)^{\mathrm{n}} \cdot\left(\mathrm{C}_{\mathrm{A}}-\frac{\mathrm{C}_{\mathrm{P}}}{\mathrm{Ke}}\right)
$$


$\alpha \geq \alpha_{\max } \quad \frac{\mathrm{d} \alpha}{\mathrm{dt}}=0$

The value of $\mathrm{n}$ determines the extent to which the conversion rate decreases with increasing conversion of the material. For example when the core reaction, according to a simple shrinking core reaction, is limiting the overall reaction rate the value of $n=2 / 3$. From experiments it was observed that the maximum conversion $\left(\alpha_{\text {max }}\right)$ of the material depends on the $\mathrm{H}_{2} / \mathrm{H}_{2} \mathrm{O}$ ratio in the reactant gas and the temperature applied [4] (Chapter 6). The relative conversion rate becomes very low when approaching $\alpha_{\max }$. The reaction rate constant $k(T)$ is dependent on the temperature and the material properties. For example in the grainy pellet model $\mathrm{k}(\mathrm{T})$ is directly related to the grain size. The value of $\mathrm{k}(\mathrm{T})$ in the model is derived from packed bed experiments with hydrogen as reduction gas (Chapter 5).

Equation 4.2 is used to interpret the increase in iron oxide conversion in the fed batch reactor as a function of the amount of oil fed in time. For the gas phase components (A and P) CISTR behavior is assumed. The inlet concentration of reduction gases $\left(\mathrm{C}_{\mathrm{A}}\right)$ is estimated from experimental results and the equilibrium constant $K_{e}$ is taken for the reduction of magnetite to wustite with hydrogen. The conversion of the gas phase is used to calculate the conversion of the iron oxide in the reduction. From this conversion the amount of hydrogen produced in the oxidation is calculated by assuming that full oxidation back to $\mathrm{Fe}_{3} \mathrm{O}_{4}$ is achieved. The calculated hydrogen production per dry $\mathrm{kg}$ oil in a redox cycle is compared with the experimental results. $\alpha_{\max }$ and $\mathrm{n}$ are used as fit parameters in this model.

\subsection{Experimental}

\subsubsection{Set-up}

The set-up is described in detail in Chapter 3.

\subsubsection{Materials}

Pyrolysis oil from the pyrolysis of pine wood is obtained from the Biomass Technology Group (Enschede, the Netherlands). The composition of the pyrolysis oil is given in Table 4.1 . 
Table 4.1: Elemental composition and water content of the pyrolysis oil.

\begin{tabular}{ll}
\hline Component & Oil \\
\hline $\mathrm{C}$ & Wt \%(wet) \\
\hline $\mathrm{H}$ & 34 \\
$\mathrm{O}^{*}$ & 8 \\
$\mathrm{H}_{2} \mathrm{O}$ & 58 \\
\hline
\end{tabular}

* Determined by difference

Two types of iron oxides are used: i) a catalytic iron oxide, normally used in the ammonia industry, obtained from the Boreskov Institute of Catalysis (Novosibirsk, Russia), and ii) grinded sintered pellets, used for steel production in blast furnaces from CORUS (IJmuiden, The Netherlands). The iron oxides will be referred to as BIC iron oxide and BF iron oxide and details are given in Chapter 3. The BIC iron oxide has initially a high surface area of $31.2 \mathrm{~m}^{2} / \mathrm{g}$. However, after repeated cycling (14 cycles) at $800^{\circ} \mathrm{C}$ the surface area has diminished and ultimately a surface area of 0.37 $\mathrm{m}^{2} / \mathrm{g}$ was obtained in Chapter 3. To have a minimal effect of deactivation on the experimental results presented in this chapter, two additional high temperature redox cycles are performed (T reduction is $970-950{ }^{\circ} \mathrm{C}$ ) with this previously deactivated BIC iron oxide material. After these two high temperature redox experiments and after all redox cycles conducted in this chapter the measured BET surface area is in the range of $0.05-0.1 \mathrm{~m}^{2} / \mathrm{g}$ for the BIC iron oxide. This confirms that a strong deactivated material is used and that structural changes and accompanying deactivation of the material will have a minimum effect on the results presented in this chapter. Also the $\mathrm{BF}$ iron oxide, which is a non-porous iron oxide, was previously used (20 cycles) (Chapter 3 ) and deactivation of this material will be minimal as the surface area of the fresh material $\left(\mathrm{BET}=0.19 \mathrm{~m}^{2} / \mathrm{g}\right)$ is already low.

\subsubsection{Definitions}

The indicators used to interpret the experimental data are described in Chapter 3 and in this section. The gas products measured during reduction and oxidation are used to determine the mass balance of the process. This method will not result in a complete balance, as components like tar, char and water are not included.

Two integral carbon balances are calculated. The carbon conversion to the gas phase, $\mathrm{C}_{\mathrm{gas}}$, is the amount of carbon transferred from the pyrolysis oil to gaseous 
products and is calculated from the gases formed during the pyrolysis oil injection period. The total amount of carbon measured $\mathrm{C}_{\text {tot }}$ is $\mathrm{C}_{\mathrm{gas}}$ plus the amount of carbon compounds deposited on the bed material, that react with the iron oxide or steam (during oxidation) to $\mathrm{CO}$ and $\mathrm{CO}_{2}$ after oil injection. The experiments are conducted in such a way that the major part of the carbon deposits will react with the iron oxide before the oxidation is started. Therefore the amount of carbon deposits is defined as:

$$
\zeta_{\mathrm{C} \text { deposit }}=\frac{\int_{\mathrm{t}_{\text {start } \mathrm{N}_{2} \text { injection }+\tau_{\mathrm{d}}}}^{\mathrm{t}_{\text {end } \mathrm{N}_{2}} \text { injection }+\tau_{\mathrm{d}}}\left(\Phi_{\mathrm{CO}}(\mathrm{t})+\Phi_{\mathrm{CO}_{2}}(\mathrm{t})\right) \mathrm{dt}}{\int_{\mathrm{t}_{\text {start oil injection }}}^{\text {oil injection }} \frac{\Phi_{\mathrm{m}, \mathrm{oil}}(\mathrm{t}) \mathrm{f}_{\mathrm{c}}}{\mathrm{M}_{\mathrm{c}}} \mathrm{dt}}
$$

The gas production defined in Chapter 3 represents the integral (cumulative) gas production during reduction, starting from $\mathrm{Fe}_{3} \mathrm{O}_{4}$ to a reduced iron oxide material with a certain conversion depending on the amount of oil injected and the temperature applied. The final conversion of the iron oxide obtained during reduction is difficult to control, as it is dependent on both temperature and amount of oil injected. The amount of oil injected per amount of iron oxide present in the fluidized bed is known in each experiment and defined as:

$$
\mathrm{R}=\frac{\mathrm{Fe}_{3} \mathrm{O}_{4 \text { initially present }}}{\mathrm{t}_{\text {end oil injection }} \Phi_{\mathrm{m}, \text { oil }}(\mathrm{t}) \mathrm{dt}}
$$

and will be used in this study as an experimental parameter to influence the conversion of the iron oxide at a specific temperature. The experimental results obtained at a low (high conversion) and high (low conversion) $\mathrm{R}$ values will be compared.

The conversion of the iron oxide can only be determined from the amount of hydrogen produced during the oxidation. The amount of oxygen from the iron oxide that reacted during reduction and oxidation can be used to determine the relative 
conversion of the iron oxide material in the redox cycle:

$$
\alpha\left(\mathrm{Fe}_{3} \mathrm{O}_{4}-\mathrm{Fe}_{1-\delta} \mathrm{O}\right)=\frac{\Delta \mathrm{O}_{\text {iron oxide }}}{\mathrm{S}_{0}} \cdot 100 \%
$$

The value of $\mathrm{S}_{0}$ is defined in such a way that the relative conversion $\left(\alpha\left(\mathrm{Fe}_{3} \mathrm{O}_{4}\right.\right.$ $\left.\mathrm{Fe}_{1-\delta} \mathrm{O}\right)$ ) equals 1 if full reduction of magnetite to wustite is achieved. This definition for the relative conversion is chosen as it was observed in Chapter 3 that a conversion to iron is difficult, due to the presence of water in the pyrolysis oil. The amount of hydrogen product from in a redox cycle, produced during the oxidation per kg dry oil used in the reduction is defined as:

$$
\begin{aligned}
& t_{\text {end oxidation }}+\tau_{\mathrm{d}} \\
& \int \Phi_{\mathrm{H}_{2, \mathrm{ox}}}(\mathrm{t}) \mathrm{dt} \cdot\left(\mathrm{R}_{g} \mathrm{~T} / \mathrm{P}\right) \\
& \mathrm{H}_{2, \mathrm{ox}}=\frac{\mathrm{t}_{\text {start oxidation }+\tau_{\mathrm{d}}}}{\mathrm{t}_{\text {end oil injection }}} \quad\left(\mathrm{Nm}^{3} / \mathrm{kg} \text { dry oil }\right) \\
& \int \Phi_{\mathrm{m}, \mathrm{oil}}(\mathrm{t}) \cdot\left(1-\mathrm{X}_{\mathrm{m}, \mathrm{H}_{2} \mathrm{O}}\right) \mathrm{dt} \\
& \mathrm{t} \text { start oil injection }
\end{aligned}
$$

\subsubsection{Procedure}

The redox cycles are performed in three steps in the fluidized bed as described in Chapter 3. First the reduction is performed by injecting pyrolysis oil into the fluidized bed, containing iron oxide particles (Reduction I). The temperature of the fluidized bed decreases during oil injection due to the endothermic reduction reaction, cracking and evaporation of the pyrolysis oil. This temperature decrease depends on the oil injection time and amount of pyrolysis oil injected. To reduce this temperature decrease as much as possible, a low flow of pyrolysis oil is applied. The lowest temperature obtained during reduction is defined as the reduction temperature. In this chapter the oil injection time is varied. As the same start temperature is chosen this will result in a slight fluctuation of the final reduction temperature for these experiments. During the second phase (Reduction II) only hot nitrogen is fed to the reactor to continue the reduction of the iron oxide with the earlier deposited carbon from the oil. In the third phase, the oxidation, nitrogen and steam are fed to the fluidized bed reactor, resulting in the formation of hydrogen. The gas and liquid flow rates used in the redox cycle are shown in Table 4.2. 
Table 4.2: Experimental settings for the redox experiments with fluidized iron oxides.

\begin{tabular}{lllll}
\hline & & Reduction (I) & Reduction (II) & Oxidation \\
\hline Фm pyrolysis oil & $(\mathrm{kg} / \mathrm{hr})$ & 0.25 & - & - \\
$\Phi v$ N2_atomizer & $(\mathrm{Nl} / \mathrm{min})$ & 5.5 & 5.5 & 2.4 \\
Фv N2_hot & $(\mathrm{Nl} / \mathrm{min})$ & 8.0 & 8.0 & 4.0 \\
Фm H2O_hot & $(\mathrm{kg} / \mathrm{hr})$ & - & - & 0.47 \\
ureactor $\left(\mathrm{T}=800^{\circ} \mathrm{C}\right)$ & $(\mathrm{m} / \mathrm{s})$ & 0.23 & 0.15 & 0.18 \\
Mbed $(\mathrm{Fe} 3 \mathrm{O} 4)$ & $(\mathrm{kg})$ & $1.3-1.4$ & $1.3-1.4$ & $1.3-1.4$ \\
\hline
\end{tabular}

\subsection{Results}

\subsubsection{Typical experiment for $\mathrm{R}=17$ at 800 and $900{ }^{\circ} \mathrm{C}$}

The gas products released over the entire redox cycle, comprising the three different steps are shown in Figure 4.1A and B at two temperatures. In both graphs it can be seen that pyrolysis oil gasification and iron oxide reduction are taking place in the time interval of $\mathrm{t}=0-20$ minutes (reduction step I). During oil injection a changing gas composition is observed. In the first 1-2 minutes of the experiment the $\mathrm{CO}_{2}$ is high, while at the end of oil injection mainly $\mathrm{H}_{2}$ and $\mathrm{CO}$ are produced. This effect is stronger at higher temperatures. Figure 4.1 shows that the gas composition changes with time of oil injection or progressive increase of the conversion of the material.

In Figure $4.1 \mathrm{~A}$ it can be seen that $\mathrm{CO}$ and $\mathrm{CO}_{2}$ are formed in the second reduction step, which is not the case when the reduction is performed at $920{ }^{\circ} \mathrm{C}$ (Figure 4.1B). Apparently no carbon deposits are present on the iron oxide after oil injection at $920{ }^{\circ} \mathrm{C}$ (reduction step I). The final step, the oxidation, is started at $\mathrm{t}=55$ minutes (Figure 4.1A) or 26 minutes (Figure 4.1B), and results in the production of hydrogen. The oxidation rate is high at the start but decreases with time, which can be seen from the tailing off of the initial high hydrogen production. 

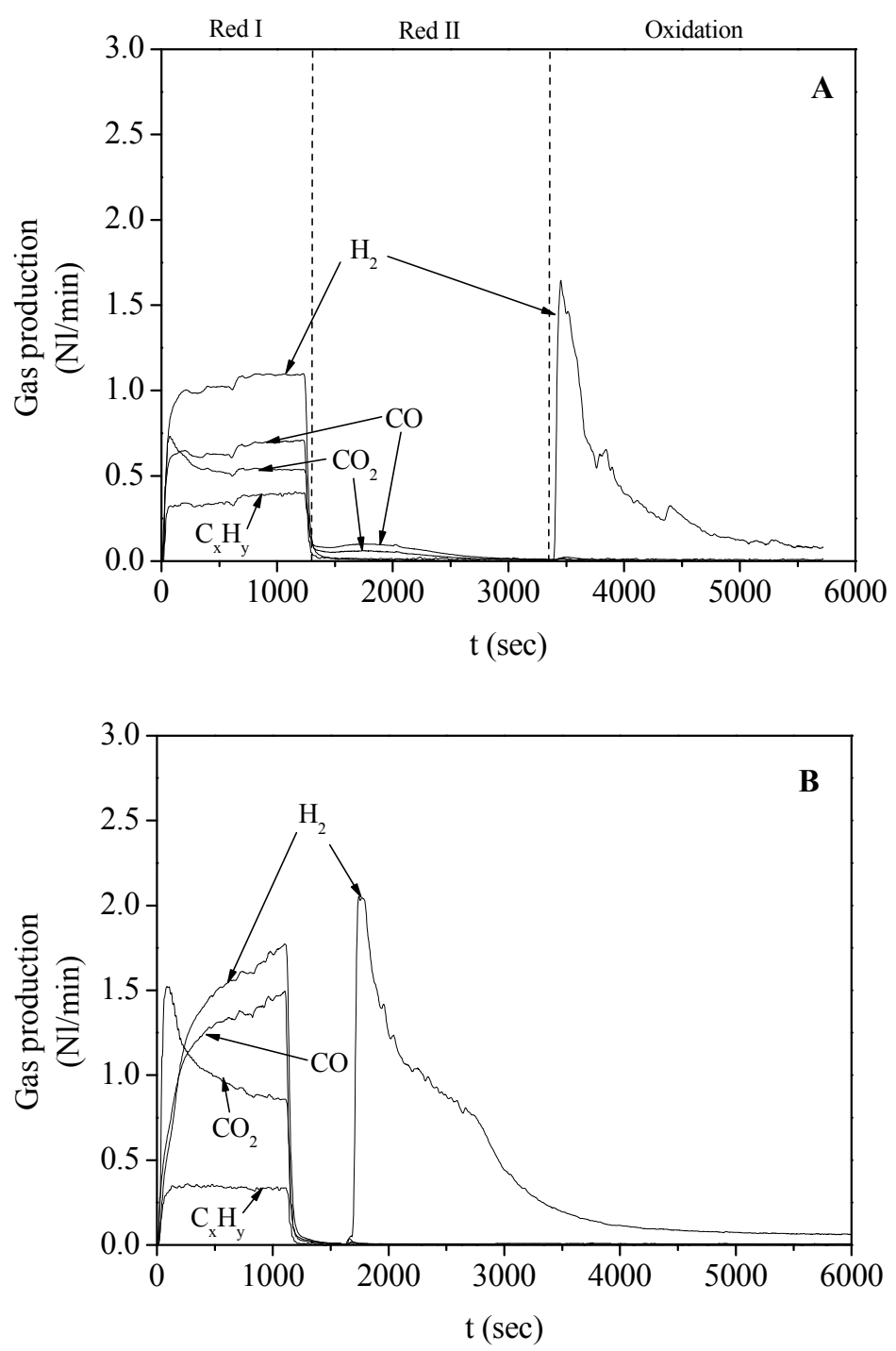

Figure 4.1: Redox cycle at 800 (A) and $920^{\circ} \mathrm{C}(\mathrm{B})$ with $\mathrm{BIC}$ iron oxide (R=17).

The total carbon to gas conversion ( $\zeta \mathrm{C}$ total) and carbon to gas conversion during oil injection ( $\zeta \mathrm{C}$ to gas) (Table 4.3 ) are clearly increasing with temperature. At a high temperature less carbon deposits are measured on the iron oxide after oil injection ( $\zeta \mathrm{C}$ deposit). The amount of carbon compounds reacting with steam during oxidation is close to zero. The increase in the total carbon conversion with temperature is not observed when a sand bed is used (Chapter 3 ) and this will be discussed in more depth in section 4.4.5. 
Table 4.3: Carbon balance of a redox cycle at 800 and $950{ }^{\circ} \mathrm{C}$.

\begin{tabular}{lcc}
\hline $\mathrm{T}\left({ }^{\circ} \mathrm{C}\right)$ & 800 & 950 \\
\hline$\zeta_{\mathrm{C} \text { to gas }}(\%)$ & 58.3 & 98.0 \\
$\zeta_{\mathrm{C} \text { deposit }}(\%)$ & 9.9 & 0.5 \\
$\zeta_{\mathrm{C} \text { total }}(\%)$ & 68.2 & 98.5 \\
\hline
\end{tabular}

\subsubsection{Application of the reaction model}

The measuring conditions applied to vary the iron oxide to oil ratio (R) are all due to changes in the oil injection time. The fluidization regime is in all cases similar except for a minor difference in the gas velocity due to a change in temperature. Obviously the same variations in ratio can be obtained by keeping the oil injection time constant and varying the amount of iron oxide present in the bed. In the latter case the contact time between the iron oxide and the gasified oil will also change, which could have an effect on the gas and solid conversions during reduction and oxidation.

In the previous section the gas production over time in the redox cycle is discussed. The observed decrease in the $\mathrm{CO}_{2}$ production clearly shows that the rate of reduction is decreasing with increasing oil injection time or conversion of the iron oxide. The final conversion of the iron oxide in the reduction can only be determined by the measured amount of hydrogen produced in the oxidation. Therefore the effect of the conversion of the iron oxide on the reduction rate is measured by performing several redox experiments with different oil injection times.

Figure $4.2 \mathrm{~A}$ shows the measured results of the hydrogen production per kg dry oil for different oil injection times at $800{ }^{\circ} \mathrm{C}$. The experimentally obtained data are fitted with equation 4.2. The strong decrease in the hydrogen production with increasing oil injection time could best be predicted with a value of $n$ between 2 and 3 in equation 4.2. A much stronger decrease in the conversion rate (Figure 4.2B) is measured than can be predicted on the basis of a simple core reaction limitation $(n=2 / 3)$. However, for any values of $n$ a strong decrease in the relative conversion rate is expected when approaching $\alpha_{\max }$.

The predicted conversion rate becomes very low (Figure 4.2B) at oil injection times higher than $500 \mathrm{~s}$. In Figure $4.1 \mathrm{~A}$ for $\mathrm{t}>500 \mathrm{~s}$ a stable gas production is observed. This observation also shows that the reduction is restricted already at low conversions of the material and at the applied temperature $\left(800^{\circ} \mathrm{C}\right) \alpha_{\max }$ is fitted to be 
0.12. The low value of $\alpha_{\max }$ may be attributed to the formation of (carbon based) contaminants on the solid surface, restricting the diffusion of reactants and products. Another explanation is the high $\mathrm{H}_{2} \mathrm{O}$ and $\mathrm{CO}_{2}$ concentration in the gas phase, which could result in poisoning of the iron oxide surface [5-7].
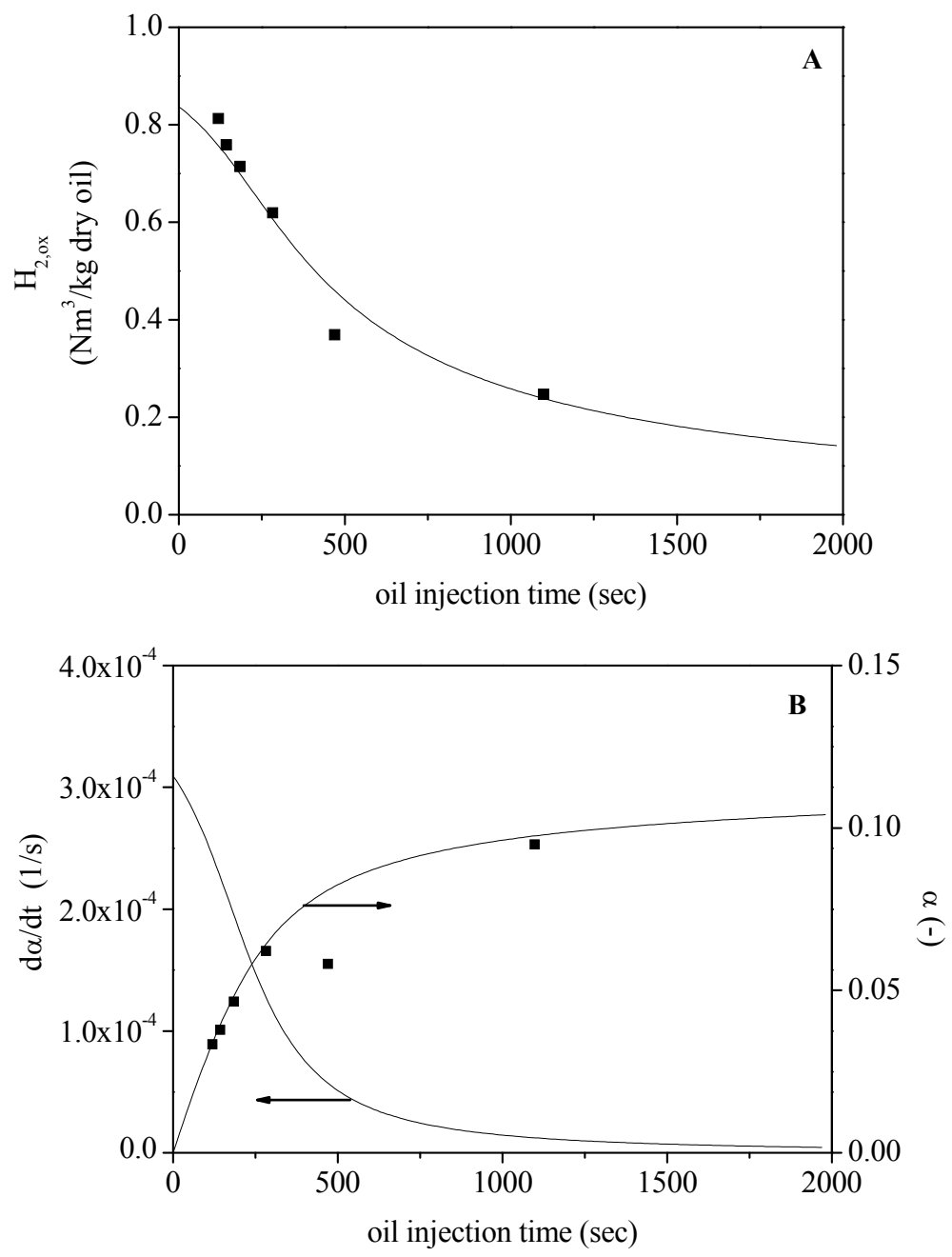

Figure 4.2: A: Hydrogen production in a redox cycle with $\mathrm{BIC}$ iron oxide at a temperature of about $800{ }^{\circ} \mathrm{C}$. The fit lines are obtained by using equation 4.2 and the fit parameters and constants given in Table 4.4. B: The predicted decrease in the conversion rate and increase of conversion with oil injection time. 
Table 4.4: Experimental conditions applied for the experimental data points and the fit parameters and constants used in the model (Figure 4.2).

\begin{tabular}{llll}
\hline \multicolumn{4}{l}{ Experimental conditions } \\
\hline $\begin{array}{l}\mathrm{T} \\
\left({ }^{\circ} \mathrm{C}\right)\end{array}$ & $\begin{array}{l}\mathrm{N}_{2} \text { flow } \\
(\mathrm{Nl} / \mathrm{min})\end{array}$ & $\begin{array}{l}\text { Oil flow } \\
(\mathrm{kg} / \mathrm{hr})\end{array}$ & $\begin{array}{l}\mathrm{M}_{\text {iron oxide }} \\
(\mathrm{kg})\end{array}$ \\
\hline 800 & 13.6 & 0.25 & 1.3 \\
\hline & & & \\
\hline Fit parameters & & Constants & \\
\hline $\mathrm{n}$ & $\alpha_{\max }$ & $\mathrm{k}(\mathrm{T})$ & $\begin{array}{l}\mathrm{K}_{\mathrm{e}} \\
(-)\end{array}$ \\
$(-)$ & $(\mathrm{m} / \mathrm{s})$ & $(-)$ \\
\hline 3 & 0.12 & 2.8 & 1.55 \\
\hline
\end{tabular}

\subsubsection{Gas production \& composition during reduction}

The effect of temperature on the average gas production during reduction (Reduction I) is shown in Figure 4.3 for high and low conversion of the iron oxide. A low $\mathrm{R}$ value of 17 results in a relative conversion of the iron oxide in the range of 7-40 $\%$, depending on the temperature applied and a high $\mathrm{R}$ value of 150 results in a low conversion (1.4-7.8 \%). In Figure 4.3 the main compounds during reduction using a $\mathrm{BIC}$ or $\mathrm{BF}$ iron oxide are compared with the gas production obtained over a sand bed and with equilibrium predictions. 

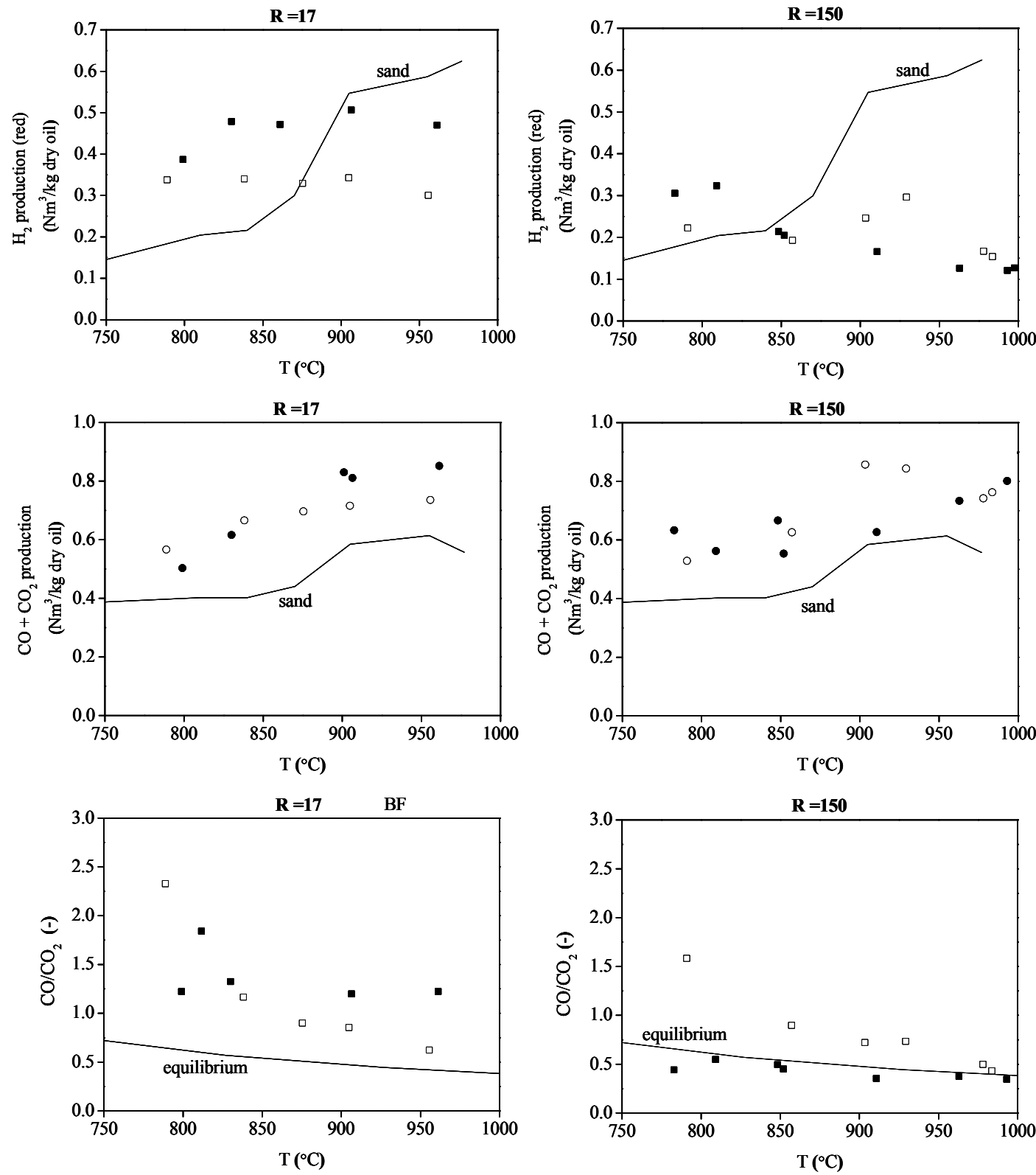

closed symbol : BIC iron oxide open symbol : BF iron oxide

Figure 4.3: Average gas production during reduction/gasification with pyrolysis oil over and $\mathrm{BIC}$ iron and $\mathrm{BF}$ oxide bed with $\mathrm{Fe3O4}$ /oil ratios of 17 and 150. 
The gas production changes with increasing oil injection time. The gas production shown in Figure 4.3 represents the integral gas production during oil injection, starting with $\mathrm{Fe}_{3} \mathrm{O}_{4}$. Therefore the gas production at a high iron oxide conversion $(\mathrm{R}=17)$ includes the gas production at different conversion degrees of the material. To which extent the gas production changes can be seen in Figure 4.1, where the gas production with increasing oil injection time (decreasing $\mathrm{Fe}_{3} \mathrm{O}_{4} /$ oil ratio) for two temperatures is shown.

The total dry gas production measured in the experiments with both iron oxides is about $1.2 \mathrm{Nm}^{3} / \mathrm{kg}$ dry oil when a high conversion of the iron oxide is obtained $(\mathrm{R}=17)$. A lower dry gas production (average $1.0 \mathrm{Nm}^{3} / \mathrm{kg}$ dry oil) obtained at a low conversion $(\mathrm{R}=150)$ can be explained by the fact that the reduction rate is higher and therefore more $\mathrm{H}_{2} \mathrm{O}$ is produced at the expense of hydrogen.

Both iron oxides favor the formation of $\mathrm{H}_{2}$ compared to the sand bed, when a high conversion $(\mathrm{R}=17)$ of the iron oxide is achieved and at a temperature lower than $870{ }^{\circ} \mathrm{C}$. A lower hydrogen production would be expected when reduction reactions with hydrogen are taking place. Both iron oxides work as a shift catalyst resulting in more $\mathrm{H}_{2}$ (with the BIC iron oxide being the most active catalyst) resulting in the highest hydrogen production at these conditions. Although the shift reaction does not influence the total reduction potential of the gas phase, it does influence the concentration of $\mathrm{H}_{2}$ and $\mathrm{CO}$. As the reduction with $\mathrm{H}_{2}$ is faster than $\mathrm{CO}$, the shift reaction might ultimately influence the reduction rate of the iron oxide with the gas phase [4]. The change in temperature hardly has an effect on the hydrogen production when the conversion of the iron oxide is relatively high, probably due to the dominating water gas shift equilibrium. The hydrogen production decreases with increasing temperature for especially the BIC iron oxide when the conversion is low $(\mathrm{R}=150)$, indicating that the reduction reaction is benefitted.

A lower hydrocarbon production is obtained with iron oxide compared to sand, but the differences are small, especially at high temperatures (Table 4.5). This small difference is mainly caused by the increased $\mathrm{C}_{2}{ }^{+}$conversion with iron oxide as bed material. The methane production is hardly affected by the temperature or the presence of the iron oxide. Reforming of the methane would require a reforming catalyst, preferably nickel. Addition of such a catalyst to the fluid bed containing iron oxide as well would therefore benefit the overall process efficiency.

The amount of $\mathrm{C}_{2}{ }^{+}$hydrocarbons produced during reduction is influenced by 
the temperature and does not appear to depend on the conversion or type of iron oxide. In the Chapter 3 it was stated that the BIC iron oxide has a beneficial effect on the steam reforming of $\mathrm{C}_{2}^{+}$components compared to the $\mathrm{BF}$ iron oxide, which is only observed in the present experiments from the results obtained at $950{ }^{\circ} \mathrm{C}$ (see conversion of $\mathrm{C}_{2} \mathrm{H}_{4}$ in Table 4.5). The low surface area of the deactivated BIC iron oxide particles probably reduces the catalytic activity of the iron oxide.

Table 4.5: Hydrocarbon compounds produced out of pyrolysis oil by gasification, using iron oxide and an inert sand as bed material.

\begin{tabular}{llllllll}
\hline & & BIC & & BF & & Sand & \\
\hline $\mathrm{Fe}_{3} \mathrm{O}_{4} /$ oil & $(\mathrm{g} / \mathrm{g})$ & 17 & 17 & 17 & 17 & & \\
\hline $\mathrm{T}$ & $\left({ }^{\circ} \mathrm{C}\right)$ & 800 & 950 & 789 & 950 & 810 & 950 \\
\hline $\mathrm{CH}_{4}$ & $\mathrm{Nm}^{3} / \mathrm{kg}$ dry oil & 0.10 & 0.10 & 0.10 & 0.09 & 0.12 & 0.11 \\
$\mathrm{C}_{2} \mathrm{H}_{4}$ & $\mathrm{Nm}^{3} / \mathrm{kg}$ dry oil & $3.310^{-2}$ & $0.410^{-2}$ & $3.610^{-2}$ & $1.810^{-2}$ & $5.010^{-2}$ & $1.510^{-2}$ \\
$\mathrm{C}_{2} \mathrm{H}_{6}$ & $\mathrm{Nm}^{3} / \mathrm{kg}$ dry oil & $2.010^{-3}$ & - & $2.010^{-3}$ & - & $1.710^{-3}$ & $0.410^{-3}$ \\
\hline
\end{tabular}

The $\mathrm{CO}+\mathrm{CO}_{2}$ production and the $\mathrm{CO} / \mathrm{CO}_{2}$ ratio compared with the equilibrium ratio (based on the reduction of $\mathrm{Fe}_{3} \mathrm{O}_{4}$ to $\mathrm{Fe}_{0.945} \mathrm{O}$ with $\mathrm{CO}$ ) are also given in Figure 4.3 The $\mathrm{CO}+\mathrm{CO}_{2}$ production clearly increases with increasing temperature and does not seem to be dependent on the conversion of the iron oxide. The increased production is mainly caused by the enhanced carbon to gas conversion of oil (section 4.4.5) with increasing temperature.

The $\mathrm{CO} / \mathrm{CO}_{2}$ ratio is much lower with an iron oxide bed compared to the sand bed under all experimental conditions applied. The $\mathrm{CO} / \mathrm{CO}_{2}$ ratio with the sand bed is in the range of 6-7 as only small amounts of $\mathrm{CO}_{2}$ are produced. The lower $\mathrm{CO} / \mathrm{CO}_{2}$ ratio with the iron oxide is an indication that reduction reactions are taking place. The equilibrium $\mathrm{CO} / \mathrm{CO}_{2}$ ratio is obtained with $\mathrm{BIC}$ iron oxide when the conversion of the iron oxide is low $(\mathrm{R}=150)$. This is also the case for the $\mathrm{BF}$ iron oxide, but only if a high temperature of $975{ }^{\circ} \mathrm{C}$ is applied. When the conversion of the iron oxide increases the equilibrium $\mathrm{CO} / \mathrm{CO}_{2}$ ratio is not achieved $(\mathrm{R}=17)$, which indicates that not the full reduction capacity of the oil is being used. Increasing the temperature is beneficial for the reduction (lower $\mathrm{CO} / \mathrm{CO}_{2}$ ratio) with $\mathrm{BF}$ iron oxide, while the $\mathrm{CO} / \mathrm{CO}_{2}$ ratio seems unaffected by temperature for the $\mathrm{BIC}$ iron oxide. A better reduction of the iron oxide with $\mathrm{CO}$ could be obtained with the $\mathrm{BF}$ iron oxide compared to the $\mathrm{BIC}$ iron oxide at temperatures higher then $825^{\circ} \mathrm{C}$ and high conversions of the iron oxide $(\mathrm{R}=17)$. When a relatively high conversion of the iron oxide is obtained the reduction rate reduces 
(section 4.4.2) and other reactions, like the water gas shift reaction, will determine the final gas composition after reduction. This may result in a more constant $\mathrm{CO} / \mathrm{CO}_{2}$ ratio for the BIC iron oxide with temperature.

\subsubsection{Hydrogen production}

The hydrogen produced in the oxidation is the only means to determine the oxygen transfer of the iron oxide per unit of oil. This hydrogen production per kg dry oil is shown in Figure 4.4 for different relative conversions of the iron oxide obtained in the redox cycle. This figure shows that the hydrogen production per $\mathrm{kg}$ dry oil decreases with an increasing relative conversion of the material. This means that the efficiency of the reduction with oil is high at low conversion of the iron oxide, but decreases strongly when the relative conversion of the iron oxide increases during reduction. This was also discussed in section 4.4.2, where a decrease in the relative conversion rate is described with increasing conversion of the iron oxide. The relative conversion rate decreases strongly when the relative conversion of the iron oxide approaches a certain maximum value $\left(\alpha_{\max }\right)$.

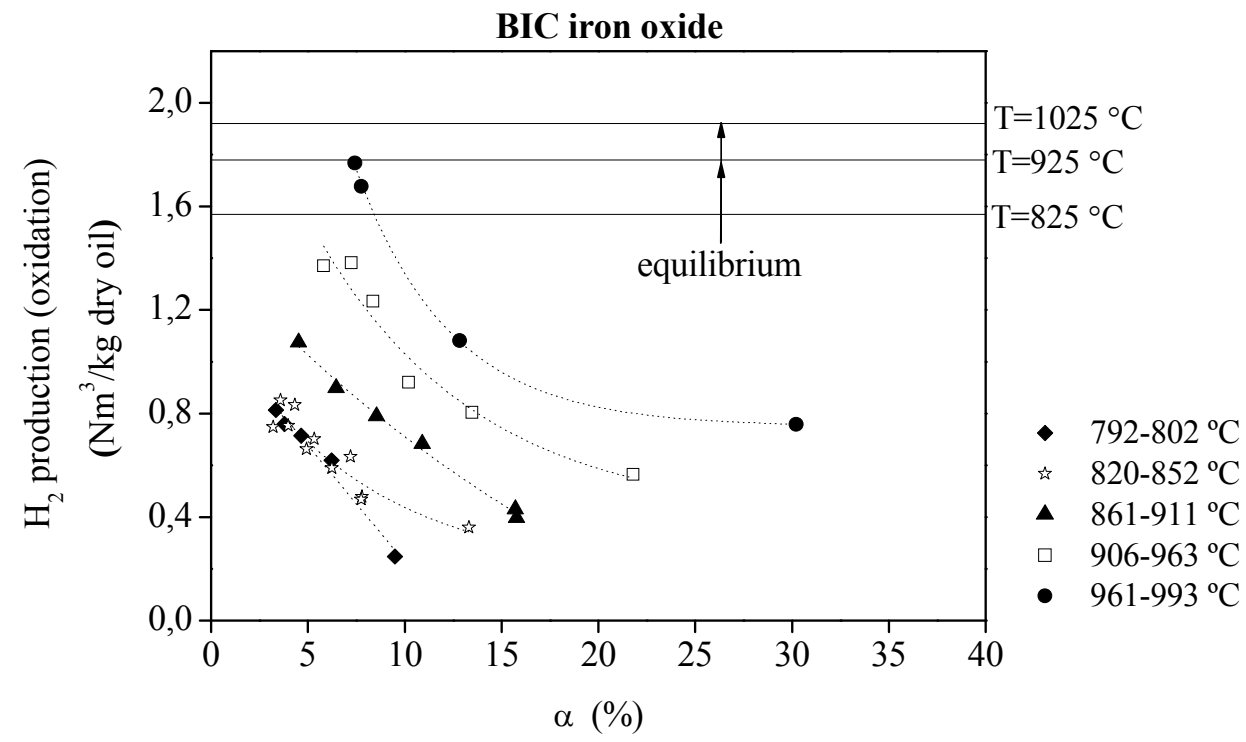




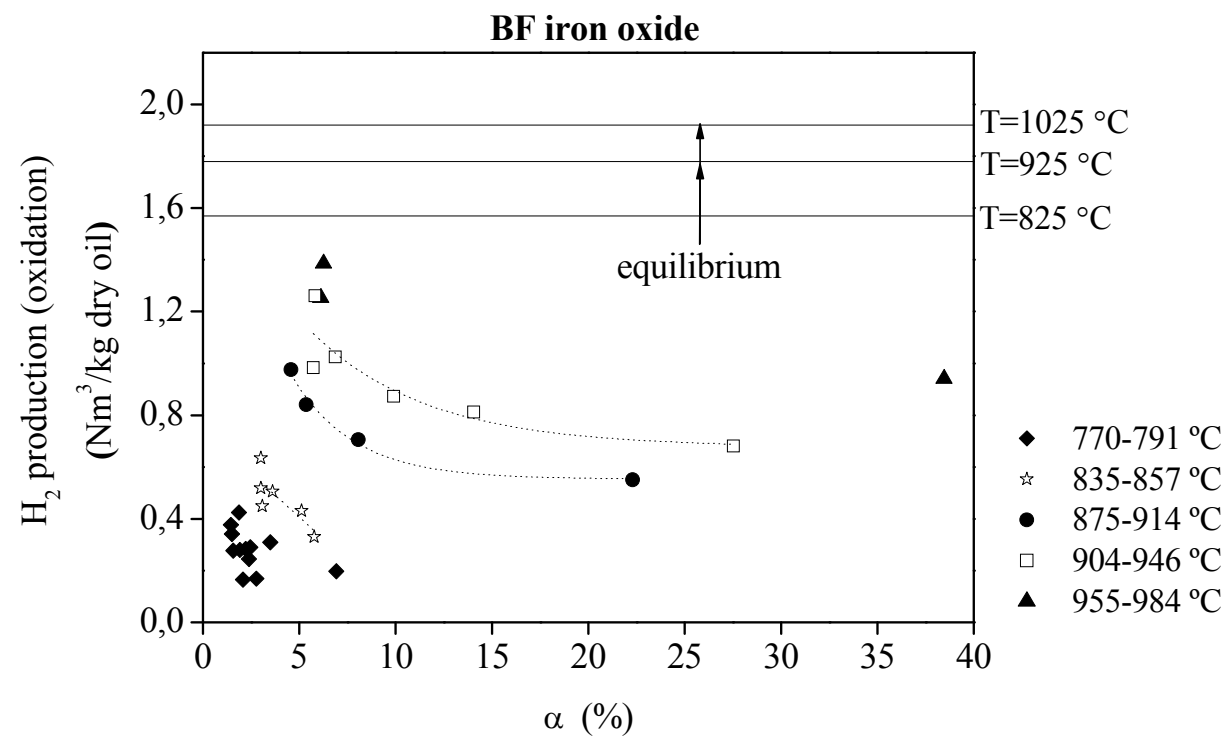

Figure 4.4: Hydrogen production obtained in the oxidation for different temperatures and relative conversions of the iron oxide in the redox cycle. The relative conversion $\alpha$ is the conversion of magnetite to wustite in this figure.

For both iron oxides the experimental data points have a linear appearance for the tests performed at temperatures less than about $900{ }^{\circ} \mathrm{C}$, with an intercept of the $\mathrm{x}$ axis near the maximum obtainable conversion $\left(\alpha_{\max }\right)$. For higher temperatures the hydrogen production levels off with increasing conversion, which is caused by the slow conversion rate. A limitation of the reduction of magnetite to wustite based on thermodynamics is not expected as the reduction potential of the gas phase obtained when pyrolysis oil is gasified is high enough to enable the full reduction of magnetite to wustite (Chapter 2). It can therefore be concluded that the full reduction to wustite is kinetically restricted; transport of reactant/product gases or $\mathrm{Fe}^{2+}$ ions to the reaction site through the product layer $\left(\mathrm{Fe}_{1-\delta} \mathrm{O}\right)$ becomes slow or impossible with increasing conversion. In Chapter 6 it is shown that the conversion of the iron oxide decreases with an increasing water content in the gas phase. In this case also a lower conversion than expected (based on thermodynamics) has been obtained, which could only be attributed to kinetic limitations, like diffusion, in the material.

The BIC iron oxide appears to approach $\alpha_{\max }$ at a lower conversion compared to the BF iron oxide. Apparently the reduction of the BIC iron oxide is blocked at a certain conversion, while the reduction of $\mathrm{BF}$ iron oxide is slowly continued. The 
porous BIC iron oxide (before deactivation) can initially be represented as a collection of grains in the iron oxide particle. The measured BET surface area is low for the BIC iron oxide used in this study, which might indicate that the outer layer of the particle is sintered. This however does not necessarily mean that the inner material of the particles does not still consists of grains. When the outer layer of the particle is completely converted during reduction, blockage of the grains in the centre of the particle can occur. In this case gas diffusion to the centre of the particle is blocked and the reduction cannot continue by slow solid state diffusion as the contact area between the grains at the outer layer and the grains in the particle may be limited. In the case of the non-porous BF iron oxide the reduction may continue by slow diffusion processes to the center of the solid particle.

It can be seen in Figure 4.4 that the maximum obtainable relative conversion $\left(\alpha_{\max }\right)$ of the iron oxide increases with increasing temperature. This can be expected as the reduction improves with higher temperatures, which is caused by a more favorable equilibrium for the reduction of iron oxide with $\mathrm{CO}$ and $\mathrm{H}_{2}$ and an increased pyrolysis oil to $\mathrm{CO}$ and $\mathrm{H}_{2}$ gasification, partly on the expense of $\mathrm{H}_{2} \mathrm{O}$ (Chapter 3).

The equilibrium hydrogen production, based on the oil composition and the $\mathrm{Fe}_{3} \mathrm{O}_{4} / \mathrm{Fe}_{1-\delta} \mathrm{O}$ equilibrium, can be approached experimentally at high temperatures ( $\mathrm{T}$ $>900{ }^{\circ} \mathrm{C}$ ) and a low relative conversion of the iron oxide (Figure 4.4). This can be expected at these temperatures as the experimental oil to gas conversion is near completion at these temperatures (Figure 4.5) and therefore the whole oil will contribute to the reduction (section 4.4.5). For lower temperatures only part of the oil is converted to the gas phase and therefore the equilibrium hydrogen production can not be reached in the experimental set-up at these temperatures.

The higher hydrogen production with BIC iron oxide compared to the BF iron oxide at low conversion can be a result of the presence of additives in the BIC iron oxide, which enable a better reduction. Furthermore the enhanced water gas shift reaction, especially with BIC iron oxide, results in a better reduction at low temperatures.

\subsubsection{Carbon conversion}

The carbon to gas conversion $\left(\zeta_{\mathrm{C}}\right.$ to gas $)$ is shown in Figure 4.5. Only data for $\mathrm{R}<60$ is given in this figure as these data points are less influenced by experimental errors. It is previously observed from the $\mathrm{CO}$ and $\mathrm{CO}_{2}$ gas production in Figure 4.3, 
that the carbon to gas conversion is mainly influenced by temperature and hardly by the conversion of the iron oxide. The scatter observed in Figure 4.5 is therefore not expected to be caused by a difference in conversion of the iron oxide obtained in the experiments. The scatter may be due to agglomeration of the iron oxide in the fluidized bed or fluctuations in the atomization of the oil. Strong agglomeration of the iron oxide (no fluidization of the bed material measured) occasionally occurred at the highest temperatures applied $\left(\mathrm{T}>950{ }^{\circ} \mathrm{C}\right)$ and resulted in a decrease of the carbon to gas conversion and increase in the formation of carbonaceous compounds in the reactor. The experiments, in which strong agglomeration occurred, are not included in Figure 4.5. This however shows, that if some agglomeration of iron oxide takes place this might influence the carbon to gas conversion during oil injection. Scatter may also be a result of small differences in atomization of the pyrolysis oil with each experiment. If carbonaceous compounds are formed on the atomizer during oil injection and are not being removed (during oxidation or by the attrition of the iron oxide bed), this may result in a slightly worse atomization of the oil in the following experiment.

Near complete conversion of oil to the gas phase is possible in a BIC iron oxide bed; at a temperature of $1030-960{ }^{\circ} \mathrm{C}$, an oil to gas conversion of $99.6 \%(\mathrm{R}=17)$ could be obtained. Another experiment at a temperature of $965-906{ }^{\circ} \mathrm{C}$ shows an oil to gas conversion of $98.0 \%(\mathrm{R}=17)$. Thus complete gasification at high temperatures is possible, although the experiments are afflicted with some technical difficulties. Furthermore the high oil to gas conversion at $\mathrm{R}=17$ shows that the reaction of the carbon deposits with the iron oxide is less influenced by the conversion of the iron oxide. Apparently the presence of carbon on the surface results in a high local reduction potential, which results in a better reduction even when a product layer has been formed.

The gas production during reduction and oxidation is shown at $800{ }^{\circ} \mathrm{C}$ and $950^{\circ} \mathrm{C}(\mathrm{R}=17)$ in Figure 4.1. It can clearly be seen from this figure that the reaction of carbon with the iron oxide is continued after oil injection at a temperature of $800{ }^{\circ} \mathrm{C}$, which does not show at $950{ }^{\circ} \mathrm{C}$. This shows that the reaction of iron oxide with carbonaceous deposits is much slower when a low temperature is applied. 


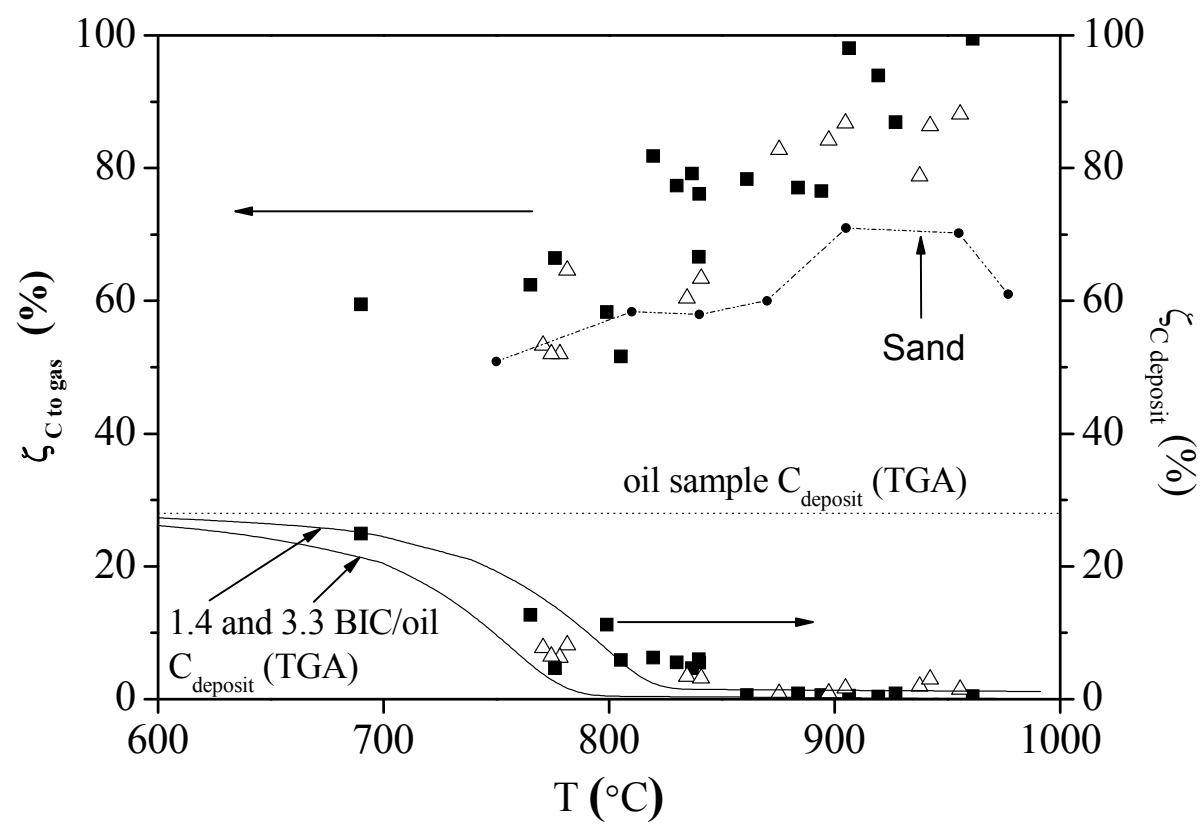

closed symbol : BIC iron oxide open symbol : BF iron oxide

Figure 4.5: Carbon to gas conversion ( $\zeta \mathrm{C}$ to gas) and carbon deposition $(\zeta \mathrm{C}$ deposit $=\zeta$ $C$ total - $\zeta C$ to gas) obtained after oil injection using BIC and BF iron oxide as bed material for different temperatures. The shown data is obtained from experiments with a $\mathrm{Fe}_{3} \mathrm{O}_{4} /$ oil ratio $<60$. Furthermore TGA data is included.

The reaction of deposited carbon with the iron oxide clearly has an effect on the carbon to gas conversion during oil injection. This can be seen in Figure 4.5, in which it is shown that the carbon to gas conversion is higher when an iron oxide bed is used instead of a sand bed at temperatures above $850{ }^{\circ} \mathrm{C}$. Apparently, gasifying the pyrolysis oil over a fluidized bed, containing an active solid oxygen source (the iron oxide), improves the gasification of the oil. At temperatures below $800{ }^{\circ} \mathrm{C}$ the carbon to gas conversion is hardly influenced by the presence of the iron oxide. In Figure 4.5 the amount of carbon from the oil, which reacted with the iron oxide in the period between oil injection and oxidation $\left(\zeta_{\mathrm{C} \text { deposit }}\right)$ is also shown. There is no distinction in the amount of carbon reacting in the second reduction phase between the BIC and BF iron oxide. Figure 4.5 also shows that hardly any carbonaceous deposits remained on the surface after oil injection at temperatures above $850{ }^{\circ} \mathrm{C}$. The reaction of the carbonaceous deposits with $\mathrm{Fe}_{3} \mathrm{O}_{4}$ is tested with TGA and discussed in more detail in 
section 4.4.6.

The carbonaceous compounds that react with the iron oxide consist probably of secondary char (carbon content $>70-73 \mathrm{wt} \%$ ) [8]. The decrease in the measured amount of carbon depositions on the iron oxide $\left(\zeta_{\mathrm{C} \text { deposit }}\right)$ in the second reduction step at high temperatures can be caused by two mechanisms: (I) less char is formed on the iron oxide during oil injection with increasing temperature or/and (II) the reaction rate of iron oxide with char becomes higher with increasing temperature. In Chapter 3 it was found that the amount of carbon deposits is independent of temperature in a sand bed. Therefore the first mechanism is unlikely. Mechanism II can explain the decrease in the amount of carbon deposits measured in reduction step II and can also explain the improved carbon to gas conversion during reduction step I when higher temperatures are applied in the reduction.

\subsubsection{Iron oxide oil reaction in a TGA}

To study the reaction of the carbonaceous deposits, formed during the gasification of oil, with iron oxide thermo gravimetric analysis (TGA) are performed. In these TGA experiments oil evaporation from oil and oil/BIC iron oxide mixtures samples are studied. In these experiments the iron oxide is present in the form of $\mathrm{Fe}_{2} \mathrm{O}_{3}$ at the start of the reaction in contrast to the fluidized bed experiments, where the $\mathrm{BIC}$ iron oxide consists mainly of $\mathrm{Fe}_{3} \mathrm{O}_{4}$ at the start of the reaction.

Figure 4.6A shows the weight loss rate when oil is heated. At the start of the ramping up of the temperature the light compounds and water are clearly evaporating from the oil, resulting in a peak at about $100{ }^{\circ} \mathrm{C}$. The evaporation of the oil sample is almost finished at a temperature of $550^{\circ} \mathrm{C}$, with an oil to gas conversion (mass based) of $87.9 \%$. At this temperature most of the components in the oil have evaporated and the residue consists mainly of secondary char [8]. The weight loss rate of the oil sample is close to zero when the temperature ramp is continued from $550{ }^{\circ} \mathrm{C}$ up to 900 ${ }^{\circ} \mathrm{C}$ in the TGA.

In Figure 4.6B-D the weight loss rate for different oil/BIC iron oxide mixture samples (in different weight ratios) is given. Again a high rate is visible at $100{ }^{\circ} \mathrm{C}$, due to the evaporation of light components and water from the oil. Between 200 and 550 ${ }^{\circ} \mathrm{C}$ a steady decrease in the weight is observed as the oil evaporation is continued and, in the case of an oil/BIC iron oxide mixture, the reduction of $\mathrm{CuO}$ to $\mathrm{Cu}$ and $\mathrm{Fe}_{2} \mathrm{O}_{3}$ to $\mathrm{Fe}_{3} \mathrm{O}_{4}$ are expected to take place here (based on thermodynamics). 


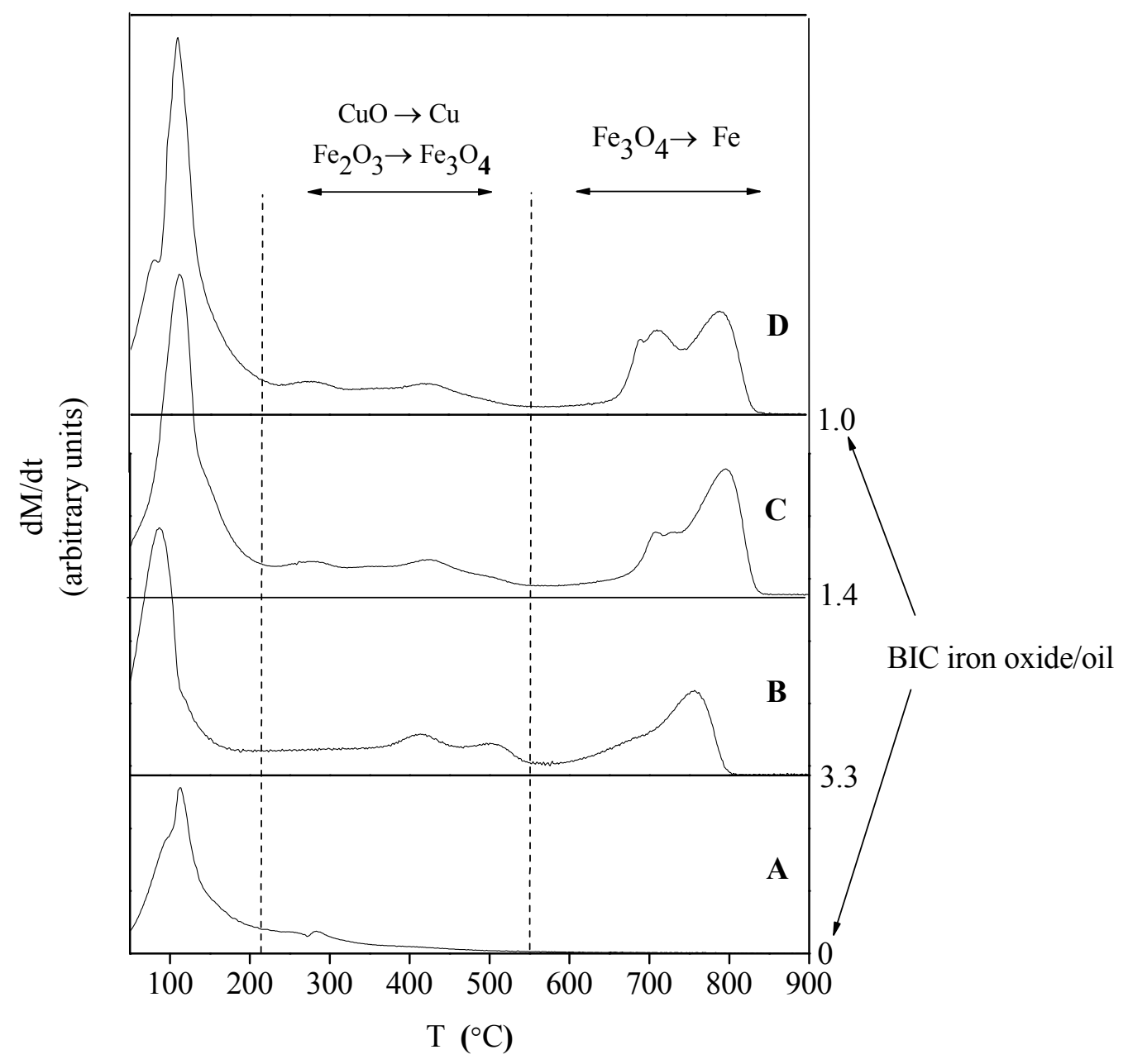

Figure 4.6: TGA result of an oil sample (A) and three different BIC iron oxide/oil samples ((g/g) 1.0-3.3). (B-D). $\mathrm{T}_{\text {ramp }}=20^{\circ} \mathrm{C} / \mathrm{min}, \mathrm{N}_{2}$ flow $30 \mathrm{ml} / \mathrm{min}$ (STP).

The most important observation is the decrease of the sample weight at temperatures above $550{ }^{\circ} \mathrm{C}$ when iron oxide is present in the sample. This can only be a result of the reaction of char with the iron oxide (reduction of magnetite to iron), which slowly starts to take place at $\mathrm{T}>+/-550^{\circ} \mathrm{C}$. The reaction becomes fast at temperatures $>650{ }^{\circ} \mathrm{C}$ and is completed at about $850{ }^{\circ} \mathrm{C}$ (Figure 4.6B-D). Decreasing the BIC iron oxide/oil ratio in the sample results in a higher temperature or longer time (as a temperature ramp is applied) for the reaction to be completed and also in a higher conversion of the iron oxide. The total relative conversion of oil and BIC iron 
oxide in the TGA with a BIC iron oxide/oil ratio of 1.0 is $95 \%\left(=\Delta \mathrm{M} /\left(\mathrm{M}_{\text {oil }}+\mathrm{M}_{\text {reactive }}\right.\right.$ $\mathrm{O}$ in sample) $\cdot 100 \%$ ). This means that the amount of oil added in this sample is nearly sufficient to obtain a complete reduction of the iron oxide to iron in the sample. In all further TGA experiments the BIC iron oxide/oil ratio is kept above 1.0, in which case the amount of iron oxide is sufficient to convert all the deposited char (based on a stoichiometric reduction reaction to $\mathrm{CO}_{2}$ ). XRD analysis of some TGA samples after reduction confirmed that all the char reacted with the iron oxide. Decreasing the BIC iron oxide/oil ratio below 1.0 would not result in a much higher conversion of the iron oxide and will actually result in a lower total relative conversion of the sample as a part of the char will not react. In the fluidized bed reactor an iron oxide/oil ratio well above 1.0 is used $(\mathrm{R}>17)$.

Figure 4.6 also shows that two peaks are appearing with a decreasing BIC iron oxide/oil ratio. This may be caused by the two step reduction reaction $\left(\mathrm{Fe}_{3} \mathrm{O}_{4} \rightarrow\right.$ $\mathrm{Fe}_{1-\mathrm{y}} \mathrm{O} \rightarrow \mathrm{Fe}$ ), which apparently becomes more pronounced with an increased amount of char on the iron oxide.

In Figure 4.5 the amount of char on the iron oxide $(28 \% \mathrm{C}$ of the total carbon input) expected at $550^{\circ} \mathrm{C}$ is shown. This is based on the amount of char formed from an oil sample in the TGA at this particular temperature. Char will not react with magnetite at this temperature, which has been found from TGA with the BIC iron oxide/oil samples and can therefore be related to the amount of carbonaceous deposits on the iron oxide.

The change in the amount of char on the iron oxide with increasing temperature (above $550{ }^{\circ} \mathrm{C}$ ) is calculated from the TGA results (Figure 4.5 for BIC iron oxide/oil 3.3 and 1.4). In this calculation the measured weight loss in the TGA is related to the weight of the gaseous products formed. In the reaction of char with iron oxide these products can be $\mathrm{CO}, \mathrm{CO}_{2}$ and some $\mathrm{H}_{2} \mathrm{O}$. From calculations the measured weight loss can only be attributed to the formation of $\mathrm{H}_{2} \mathrm{O}$ and $\mathrm{CO}_{2}$. In the case of $\mathrm{H}_{2} \mathrm{O}$ and $\mathrm{CO}$ formation not enough char is present on the surface to explain the measured weight loss. The amount of carbon remaining on the iron oxide ( $\left.\zeta_{\text {deposit }}\right)$ in the TGA is derived from the amount of $\mathrm{CO}_{2}$ produced in the reaction of char with iron oxide. The amount of char on the iron oxide in the TGA samples shows a similar trend as found for the amount of char on the iron oxide surface in reduction step II in the fluidized bed. In both the TGA and fluidized bed experiments the reaction of char with the magnetite is hardly taking place below $650{ }^{\circ} \mathrm{C}$ and a temperature of $850{ }^{\circ} \mathrm{C}$ is high enough to convert almost all carbon deposits to the gas phase (Figure 4.5). Based on 
thermodynamics the reaction of magnetite with solid carbon can only occur for temperatures above $700{ }^{\circ} \mathrm{C}\left(\Delta \mathrm{G}_{\text {reaction }}<0\right)$. The reaction of char with magnetite starts at a slightly lower temperature $\left(+/-650{ }^{\circ} \mathrm{C}\right)$, probably caused by the presence of oxygen in the char.

The TGA confirmed that the use of iron oxide at temperatures above $650{ }^{\circ} \mathrm{C}$ can increase the carbon to gas conversion in the fluidized bed, as the reaction of char with iron oxide is enabled above this temperature. However the rate of reaction of char with the iron oxide is only high enough at temperatures above $850{ }^{\circ} \mathrm{C}$ to enhance the carbon to gas conversion during oil injection in the fluidized bed.

\subsubsection{Oil gasification mechanism}

When oil is atomized into an inert hot sand bed, small oil droplets are formed and may either hit the solid particles and evaporate on the solid particle surface or, depending on the size, evaporate before hitting a particle. In the first case char will deposit onto the solid particle, while part of the oil is evaporated. In the second case light char particles are formed in the gas phase which can be entrained out of the fluidized bed or can deposit on the solid surface. The char that deposits on the particles can be removed from the surface by the movement of the particles in the fluidized bed. In the sand bed experiments, an average of about $5 \%$ of the total carbon input was found on the sand for all temperatures after oil injection (Chapter 3). Probably this amount is related to the specific surface area of the particles as no temperature influence is found. With a higher surface area more carbon is expected to remain on the surface and is less easily removed by attrition. About $70 \%$ of the carbon (Chapter 3 ) is converted to the gas phase at the highest temperature measured in the sand bed and therefore about $25 \%$ of the carbon is not recovered when sand is used. The non recovered carbon is attributed to the formation of low density char particles in the gas phase, which could not be separated or analyzed and are leaving the set-up with the product gas. The reaction of carbon with iron oxide can only take place if direct contact between the two phases is established. As in some cases a near complete carbon conversion to the gas phase is found at high temperatures, it is shown that it is principally possible that all formed char eventually contacts the iron oxide particles and reacts to the gas phase.

The gasification data result in the proposed mechanism as shown in Figure 4.7. This mechanism is dedicated to the gasification of char (from the oil) to the gas 
phase when iron oxides are used in the fluidized bed.

The char particles in the gas phase can deposit again on the iron oxide before being entrained out of the reactor, increasing the possibility for the char to react to $\mathrm{CO}$ and $\mathrm{CO}_{2}$. The amount of char initially formed on the surface of the iron oxide depends on the contacting pattern between the iron oxide particles and oil in the fluidized bed. The rate of attrition is largely determined by the porosity of the particles, the possibility of char to penetrate the pores and the fluidization conditions. The reaction of char with the iron oxide is enhanced by increasing the temperature and the reactivity of the bed material. Complete gasification of oil to the gas phase during oil injection is therefore possible, if the overall reaction rate of iron oxide with char is higher compared to the overall rate of char removal by attrition and the overall rate of char formation.

The char formed during gasification of the oil should be converted to $\mathrm{CO}$ and $\mathrm{CO}_{2}$ before being entrained out of the reactor to obtain a full oil to gas conversion and to optimally use the reduction potential of the oil. The final amount of char on the particle leaving the reactor should be zero to obtain a pure hydrogen product in the redox cycle, without using an intermediate stripping section.

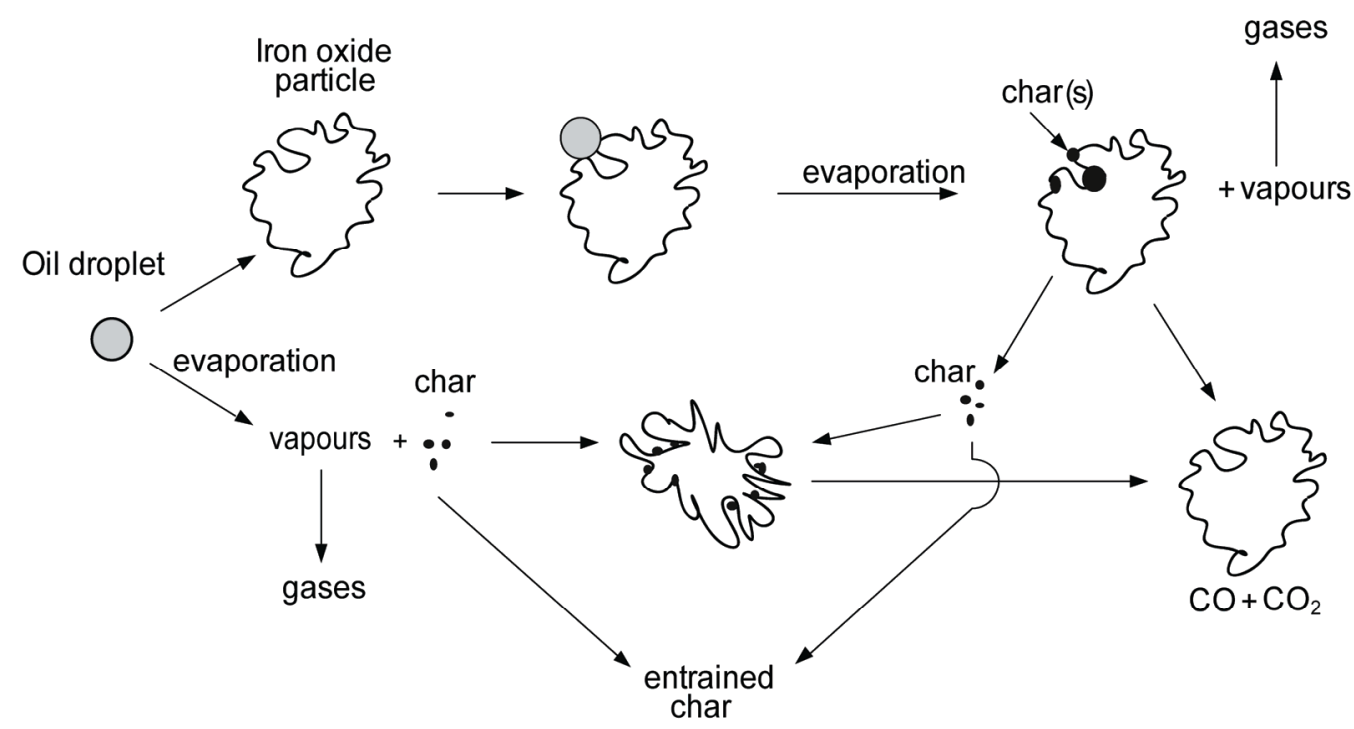

Figure 4.7: Proposed mechanism for pyrolysis oil gasification over an iron oxide bed. 


\subsubsection{Steam conversion}

The steam conversion in the oxidation is dependent on the relative conversion of the iron oxide, the temperature applied, the contact time and the type of iron oxide used. In general a high temperature results in a higher reaction rate, but decreases the equilibrium steam conversion during oxidation of the iron oxide (Chapter 2). The reaction rate is also influenced by the conversion achieved during reduction, as the oxidation becomes very slow when the oxidation to $\mathrm{Fe}_{3} \mathrm{O}_{4}$ is near completion. A higher relative conversion of the iron oxide therefore results in a higher oxidation rate at the start of the oxidation, but will eventually also end up with a low oxidation rate (Figure 4.8).

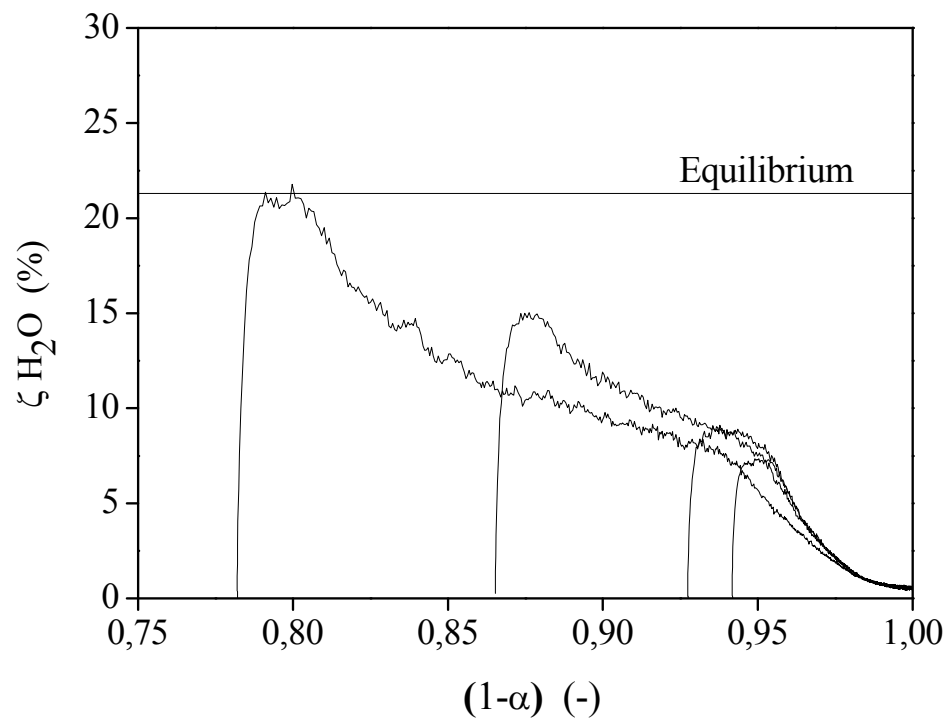

Figure 4.8: Steam conversion $\left(\mathrm{T}_{0 x}=970{ }^{\circ} \mathrm{C}\right)$ in the oxidation for different relative conversions $\left(\alpha \mathrm{Fe}_{3} \mathrm{O}_{4}-\mathrm{Fe}_{1-\delta} \mathrm{O}\right)$ obtained in the reduction.

In practice the steam conversion in the oxidation needs to be at equilibrium in order to make the overall process efficient (Chapter 2 and 7). To achieve this equilibrium conversion in the set-up the contact time of the steam with the iron oxide should be sufficient. The oxidation rate of the BIC iron oxide is higher compared to the $\mathrm{BF}$ iron oxide (Chapter 3 and 5) and therefore the equilibrium steam conversion could be obtained with the BIC iron oxide for high $\alpha\left(\mathrm{Fe}_{3} \mathrm{O}_{4}-\mathrm{Fe}_{1-\delta} \mathrm{O}\right)$ (Figure 4.8 and Chapter 3). This is not the case for the $\mathrm{BF}$ iron oxide and therefore experiments are performed to check whether the contact time of the steam with the BF iron oxide and 
the concentration of steam in the gas phase could influence the steam conversion. In these experiments the equilibrium steam conversion is not reached, although increasing the concentration or contact time resulted in both cases in a higher steam conversion. A long contact time required to obtain an equilibrium conversion of steam in the oxidation will have a negative impact on the reactor size of the oxidator. This will especially be the case when a low conversion of the iron oxide is used in the redox cycle.

A low conversion of the iron oxide in the redox cycle is on the other hand beneficial for the iron oxide reduction with oil.

\subsection{Conclusions}

This chapter shows that both temperature and conversion of the iron oxide strongly affect the efficiency of the hydrogen production from pyrolysis oil in the steam-iron process. The relative conversion rate of the iron oxide in both the reduction and oxidation is expected, according to existing particle models, to decrease to some extent with increasing relative conversion of the iron oxide. However the observed decrease in the relative conversion rate in the reduction when pyrolysis oil is used is much higher. Also the final relative conversion that can be obtained with pyrolysis oil is lower than expected (based on thermodynamics) and a full reduction to wustite could not be achieved at the applied temperatures. The presence of water in the pyrolysis oil is most probably restricting the conversion during reduction. This results in a pore utilization of the iron oxide, especially at temperatures around $800{ }^{\circ} \mathrm{C}$ and in an enhanced decrease in the relative conversion rate with increasing conversion. The maximum obtainable relative conversion of the iron oxide can be increased by increasing the temperature.

Complete gasification of pyrolysis oil ( $>98 \%)$ could be achieved in the used fluidized bed at a temperature above $850^{\circ} \mathrm{C}$ with BIC iron oxide (HT shift catalyst) as bed material. The improved gasification is attributed to the fast reaction of deposited char with the iron oxide.

In the experimental set-up the maximum possible (according to equilibrium) hydrogen production in the redox cycle is nearly achieved at a low conversion of the BIC iron oxide $\left(\alpha\left(\mathrm{Fe}_{3} \mathrm{O}_{4}-\mathrm{Fe}_{1-\delta} \mathrm{O}\right)=7 \%\right)$ and a high temperature $\left(998{ }^{\circ} \mathrm{C}\right)$. The hydrogen production at these conditions with $\mathrm{BF}$ (blast furnace iron oxide which does not reach equilibrium) and BIC iron oxide is respectively 1.39 and $1.82 \mathrm{H}_{2} \mathrm{Nm}^{3} / \mathrm{kg}$ 
dry oil. In these two cases near complete gasification of the oil and a low conversion of the iron oxide is maintained during reduction, which is required to achieve an equilibrium hydrogen production in the process.

The relative conversion rate of the iron oxide in the oxidation in the set-up is low when the oxidation is near completion. This shows that a low conversion of the iron oxide in the reduction, which is beneficial in the reduction, will have a negative effect on the oxidation. Very long contact times will be required to achieve an equilibrium steam conversion in the oxidation with a low conversion of the iron oxide.

\subsection{Nomenclature}

\begin{tabular}{|c|c|c|}
\hline $\mathrm{C}_{\mathrm{A}}$ & $\left(\mathrm{mol} / \mathrm{m}^{3}\right)$ & Concentration of reduction gases $\left(\mathrm{H}_{2}+\mathrm{CO}\right)$ \\
\hline $\mathrm{C}_{\mathrm{P}}$ & $\left(\mathrm{mol} / \mathrm{m}^{3}\right)$ & Concentration of reduction products $\left(\mathrm{H}_{2} \mathrm{O}+\mathrm{CO}_{2}\right)$ \\
\hline f & $(-)$ & Weight fraction \\
\hline $\mathrm{K}_{\mathrm{e}}$ & $(-)$ & Equilibrium constant \\
\hline $\mathrm{k}(\mathrm{T})$ & $(\mathrm{m} / \mathrm{s})$ & Temperature dependent rate constant \\
\hline M & $(\mathrm{g} / \mathrm{mol})$ & Molecular weight \\
\hline M bed & $(\mathrm{kg})$ & Mass of the bed material \\
\hline $\mathrm{n}$ & $(-)$ & Fit parameter \\
\hline $\mathrm{P}$ & $(\mathrm{Pa})$ & Pressure \\
\hline $\mathrm{R}$ & $(-)$ & Mass ratio of iron oxide and oil \\
\hline $\mathrm{R}_{\mathrm{g}}$ & $(\mathrm{J} / \mathrm{molK})$ & Gas constant \\
\hline $\mathrm{S}_{0}$ & $(\mathrm{~mol})$ & Amount of oxygen in iron oxide \\
\hline $\mathrm{T}$ & $\left(\mathrm{K}\right.$ or $\left.{ }^{\circ} \mathrm{C}\right)$ & Temperature \\
\hline $\mathrm{t}$ & $(\mathrm{s})$ & Time \\
\hline $\mathrm{u}_{\text {reactor }}$ & $(\mathrm{m} / \mathrm{s})$ & Superficial gas velocity in the fluidized bed reactor \\
\hline $\mathrm{X}$ & $(-)$ & Mole fraction \\
\hline$\alpha\left(\mathrm{Fe}_{3} \mathrm{O}_{4}-\mathrm{FeO}\right)$ & $(-)$ & $\begin{array}{l}\text { Reduction degree of iron oxides. } \mathrm{Fe}_{3} \mathrm{O}_{4} \text { is the start } \\
\text { material }\left(\alpha\left(\mathrm{Fe}_{3} \mathrm{O}_{4}-\mathrm{FeO}\right)=0\right) \text { and } \mathrm{Fe}_{0.945} \mathrm{O} \text { is the final } \\
\text { product }\left(\alpha\left(\mathrm{Fe}_{3} \mathrm{O}_{4}-\mathrm{FeO}\right)=1\right) \text {. }\end{array}$ \\
\hline$\alpha_{\max }$ & $(-)$ & $\begin{array}{l}\text { Maximum conversion of the iron oxide obtained in } \\
\text { the reduction }\end{array}$ \\
\hline$\Delta \mathrm{H}_{\mathrm{r}}^{\mathrm{o}}$ & $(\mathrm{kJ} / \mathrm{mol})$ & Reaction enthalpy \\
\hline$\Delta \mathrm{G}_{\mathrm{r}}^{\mathrm{o}}$ & $(\mathrm{kJ} / \mathrm{mol})$ & Reaction Gibbs energy \\
\hline$\zeta_{\mathrm{C} \text { to gas }}$ & $(-)$ & Conversion of carbon from the oil to the gas phase \\
\hline$\zeta_{\mathrm{C} \text { total }}$ & $(-)$ & $\begin{array}{l}\text { Conversion of carbon from the oil to the gas phase } \\
\text { and deposited on the bed material }\end{array}$ \\
\hline$\zeta_{\mathrm{C} \text { deposit }}$ & $(-)$ & $\begin{array}{l}\text { Amount of carbon from the oil that is deposited on } \\
\text { the bed material }\end{array}$ \\
\hline
\end{tabular}




\begin{tabular}{|lll|}
$\zeta_{\mathrm{H}_{2} O}$ & $(-)$ & Conversion of steam during oxidation \\
$\rho$ & $\left(\mathrm{kg} / \mathrm{m}^{3}\right)$ & Density \\
$\Phi_{\mathrm{m}}$ & $(\mathrm{kg} / \mathrm{s})$ & Mass flow \\
$\Phi_{\mathrm{v}}$ & $(\mathrm{Nl} / \mathrm{s})$ & Volumetric flow \\
$\Phi$ & $(\mathrm{mol} / \mathrm{s})$ & Mol flow \\
\hline
\end{tabular}

\subsection{Literature}

1 Szekely, J., Evans, J.W., Sohn, H.Y., 1976, Gas-solid reactions (Academic Press, New York, USA)

2 Doraiswamy, L.K. and Sharma, M.M., 1984, Heterogeneous reactions: analysis, examples, and reactor design. Vol. I: Gas-Solid and Solid-Solid reactions, (John Wiley \& Sons Inc., New York, USA).

3 Levenspiel, O., 1979, Chemical Reactor Omnibook, (Corvallis, OR, Distributed by OSU Book Stores).

4 Gasior, S.J., 1961, Report of investigations 5911 U.S.D.o.t. Interior, Editor. Bureau of Mines: Washington.

5 McKewan, M.C., 1961, Trans. of the Metal. Soc. of AIME, 221: 140-145.

6 McKewan, M.C., 1962, Trans. of the Metal. Soc. of AIME, 224: 2-5.

7 Wimmers, O.J., Arnoldy, P., Moulijn, J.A., 1986, J. of Phys. Chem., 90: 13311337.

8 Branca, C., Di Blasi, C., Elefante, R.,2005, Ind.\& Eng. Chem. Res., 44: 799. 


\title{
Chapter 5
}

\section{Observations on the reduction and oxidation of iron oxides with $\mathrm{H}_{2}$ and $\mathrm{H}_{2} \mathrm{O}$}

\begin{abstract}
The reduction and subsequent oxidation of fresh iron oxides with the model compounds $\mathrm{H}_{2}$ and $\mathrm{H}_{2} \mathrm{O}$ is studied. Both a temperature programmed reduction and isothermal reduction are applied, from which the isothermal method is found to be able to study the reduction taking place in the steam-iron process.

Results of the reduction and oxidation of iron oxides, different in composition and porosity, showed that a high porosity of the iron oxide benefits the conversion rates. Sintering of the iron oxide during reduction takes place at reduction temperatures above $600{ }^{\circ} \mathrm{C}$ and/or high conversion of the iron oxide, indicating that the formation of iron enhances temperature induced sintering. The resulting low porosity after reduction leads to a low oxidation rate in the subsequent oxidation. The oxidation rate decreases with progressive conversion during oxidation and a full oxidation to magnetite is slow or could not be measured. The presence of $\mathrm{Cr}_{2} \mathrm{O}_{3}$ in iron oxide (BIC iron oxide) prevents temperature induced sintering during reduction, resulting in both high reduction and oxidation rates. The presence of $\mathrm{SiO}_{2}$ in the iron oxide (BF iron oxide) results in a low reduction rate.
\end{abstract}




\subsection{Introduction}

The redox-process is based on a thermo chemical cycle, in which iron oxide can be reduced and oxidized between different oxidation states. Iron forms three stable solid compounds with oxygen:

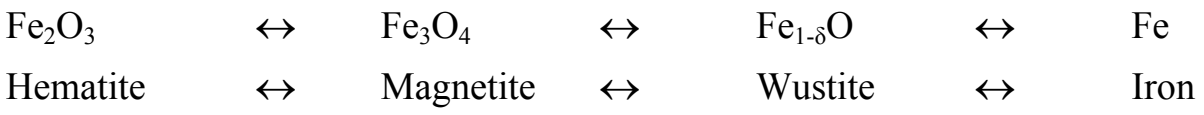

For the proposed steam-iron cycle the redox cycle will be conducted between the states of magnetite and wustite/iron. In order to design a steam-iron process fueled with pyrolysis oil it is necessary to understand the behavior of the cracking of the pyrolysis oil and the behavior of the iron oxide during reduction and oxidation. In this chapter the heterogeneous reduction and oxidation reaction between $\mathrm{H}_{2}$ (reduction) or $\mathrm{H}_{2} \mathrm{O}$ (oxidation) and three types of iron oxide, which were also applied in the fluidized bed set-up will be discussed. In this way the observations help to understand results obtained in the fluidized bed set-up with these iron oxides. The two methods applied are temperature programmed and isothermal reduction/oxidation.

\subsection{Reduction mechanism}

In this paragraph only the reduction mechanism will be discussed, as the oxidation mechanism of the reduced iron oxide will be described in more detail in Chapter 6 . The structure and chemical composition of the solid phases change as the reduction progresses and varies from place to place. Many parameters affect the rate of oxygen removal and in general two phenomena are considered for the rate of the reduction of iron oxide [1-3]:

1. The transport of the reducing gas reactant from the bulk to the solid oxide phase and the subsequent transport of the oxidized gas product from the reaction front to the bulk via different transport phenomena. 


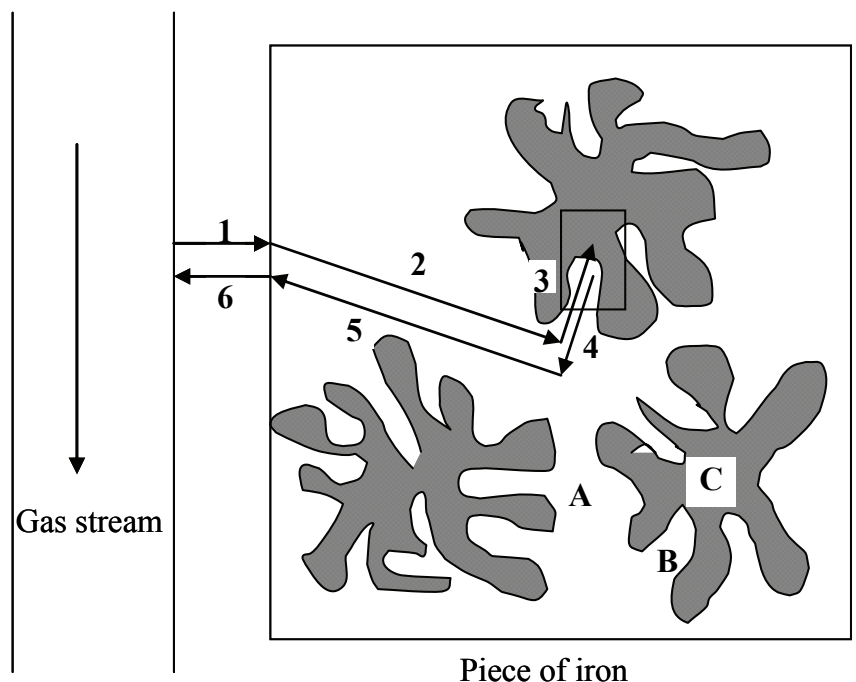

Figure 5.1: Transport of reactant and products to and from the reaction site $[1,3]$.

These different phenomena shown in Figure 5.1 are: (1) Diffusion of gas through the boundary layer.(2) Diffusion of gas through the macropores of the iron oxide. (3) Diffusion of gas through the micropores of the iron oxide. (4) Diffusion of oxidized gas through the micropores of the iron oxide. (5) Diffusion of oxidized gas through the macropores of the iron oxide. (6) Diffusion of oxidized gas through the boundary layer. When considering the effect of the diffusion of gas on reduction, it is irrelevant whether the diffusion of the reducing feed gas or the diffusion of the oxidized product from the interior to the surface of iron oxide is considered as the reduction is an equimolar reaction. However, the diffusion coefficient of the product gas during reduction is expected to be lower compared to the feed gas and will therefore determine the gas diffusion resistance.

2. The actual chemical reaction of the feed gas with the oxygen ion that is taking place at the boundary between the oxide and the gas phase. This includes the adsorption of the reducing gas, the separation of oxygen from the oxide lattice, the formation and growth of the nuclei of the reaction products, magnetite, wustite or iron and desorption of the oxidized gas molecules from the surface of the solids.

The reduction of iron oxide includes thus a sequence of subsidiary processes. The rate determining step of the reaction will change when the iron oxide becomes 
partly reduced. Different iron oxides are found in nature and these changes in composition will have an influence on the conversion rate. Besides the difference in composition, different porous structures may occur. These material influences, temperature, composition of the reducing gas, rate of gas flow may all have an influence on the reduction rate, depending on what sub-process is rate determining.

The processes described in Figure 5.1: define the particle based model, which can predict the reduction rate. The most frequently applied models are described in Appendix A and can help to acquire more understanding about what process determines the rate of reduction from the experimental results.

\subsubsection{Interfacial reaction}

Magnetite crystallizes in the cubic spinel lattice. The oxides of iron, hematite $\left(\mathrm{FeO}_{1.5}\right)$, magnetite $\left(\mathrm{FeO}_{1.33}\right)$, and wustite $\left(\mathrm{FeO}_{1.1}\right)$ have a close-packed structure of oxygen ions. The tetrahedral and octahedral interstices are occupied with $\mathrm{Fe}^{2+}$ and $\mathrm{Fe}^{3+}$ ions. Two extreme cases of spinels can occur; the normal spinel and the inverse spinel $[1,3]$.

\section{Reduction of hematite to magnetite}

The reduction of hematite to magnetite is a complex gas-solid reaction, involving complex structure changes in the intermediate oxides. The transformation of hematite to magnetite requires a redistribution of the oxygen ions from the hexagonal (HCP) to the face centered cubic (FCC) structure.

Oxygen is removed according to:

$\mathrm{O}^{2-} \quad \rightarrow \quad \mathrm{O}+2 \mathrm{e}^{-}$

The iron ions react with the free electrons according to:

$2 \mathrm{Fe}^{3+}+2 \mathrm{e}^{-} \quad \rightarrow \quad 2 \mathrm{Fe}^{2+}$ 


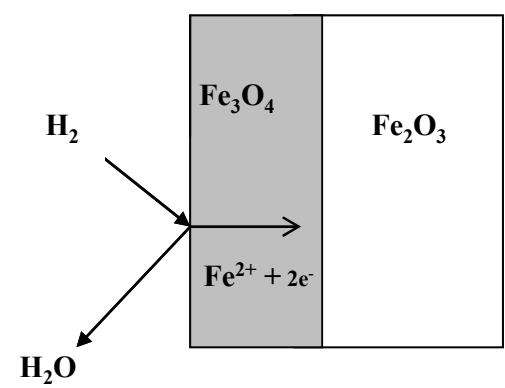

Figure 5.2: The reduction of hematite to magnetite [3].

Whenever at the surface of the oxide the ratio $\mathrm{Fe}^{3+}: \mathrm{Fe}^{2+}=2$ is reached, the hexagonal oxygen lattice transforms into the cubic magnetite lattice and hematite becomes covered with a thin layer of magnetite. The gas does not have direct access anymore to the hematite phase so that further oxygen removal occurs from the magnetite lattice (Figure 5.2). If the composition of the reducing gas is at equilibrium with magnetite, the removal of oxygen can proceed only to an extent corresponding to an iron activity that is determined by the oxygen partial pressure at the gas-magnetite interface. The iron activity at the magnetite-gas interface is higher than at the hematite-magnetite interface. This difference in activity leads to diffusional flow of iron and oxygen atoms. Because of the deficiencies in the ordering of the metal ions and the high ordering of the oxygen ions in the spinel lattice of magnetite, diffusion of metal ions is high compared to oxygen ions. On the other hand, in hematite the transport of matter is primarily the result of the diffusion of oxygen atoms. The iron ions and electrons that diffuse through the magnetite react at the hematite-magnetite interface according to:

$4 \mathrm{Fe}_{2} \mathrm{O}_{3}+\mathrm{Fe}^{2+}+2 \mathrm{e}^{-} \rightarrow 3 \mathrm{Fe}_{3} \mathrm{O}_{4}$

As a result the interface moves further into the hematite phase. The structural changes when hematite is converted into magnetite results into structural disorders [4].

\section{Reduction of magnetite to wustite}

The reduction reaction of magnetite to wustite proceeds similarly to the reduction of hematite to magnetite. During transformation of magnetite to wustite the oxygen ions are not rearranged, only the iron:oxygen ratio changes. Wustite should normally be denoted by $\mathrm{Fe}_{1-\mathrm{y}} \mathrm{O}$, as wustite can contain between $23.1-25.6 \mathrm{wt} \%$ of 
oxygen. A stoichiometric $\mathrm{FeO}$ would contain about 22.3 wt \% of oxygen. $\mathrm{FeO}$ crystallizes in the cubic $\mathrm{NaCl}$ lattice, in which the oxygen sub-lattice is fully occupied leaving iron sites in the sub-lattice vacant. The oxygen excess is therefore due to the iron deficiencies in the lattice structure. The value of $\delta$, in $\mathrm{Fe}_{1-\delta} \mathrm{O}$, gives the proportion of the vacant iron ion lattice positions relative to the available number of iron lattice sites. To satisfy the electron neutrality in the lattice $\mathrm{Fe}^{3+}$ must be present to compensate for the iron deficiency. The diffusing component in wustite and magnetite, and therefore the transformation of these oxides into another, takes place by the incorporation (during reduction) of additional iron.

\section{Reduction of wustite to metallic iron}

The lens-shaped precipitation of iron on a wustite surface is shown in Figure 5.3. When the wustite is further reduced, usually a porous sponge iron (direct reduced iron) is produced. In this case oxygen is removed from wustite by direct contact between the gas and the wustite phase. Pores are formed at the sites from which the oxygen was removed; the pore walls are subsequently covered with metallic iron.

A

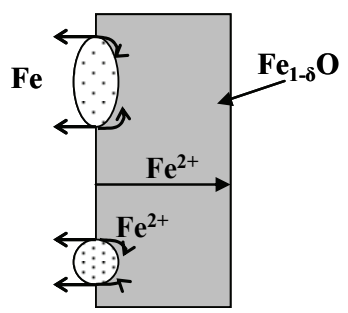

B

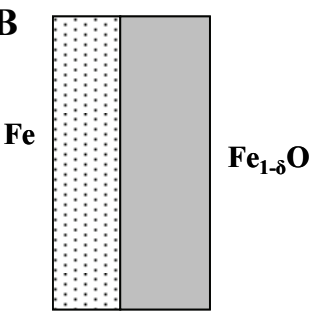

Figure 5.3: Formation of iron in the reduction of wustite. A: formation of porous iron layer. B: formation of a dense iron layer [3].

The iron ions that are formed in the pores diffuse from the removal site to the metallic iron site and condense there to form metallic iron. When the reduction progresses a layer with metallic iron is formed on the wustite. For further reduction oxygen must diffuse through the metallic iron to react with the reducing gas [5]. This diffusion of oxygen through the iron is very slow and causes a slow reduction of wustite to metallic iron. When foreign materials are added it could be possible that during reduction a more porous layer of metallic iron is formed, which would increase the reduction rate $[1,5]$ 


\section{Oxidation}

The oxidation is believed to follow the similar migration processes as in the reduction, only the direction of the mass transport is reversed [6]. The flux of iron ions to the surface of the grain will also invoke a reverse flow of oxygen ions towards the center of the particle. The oxidation may be slower compared to the reduction as the dense oxide layers which are being formed are growing during reaction. Therefore the gas diffusion resistance is increasing with increasing conversion in the oxidation, while in the reduction of wustite to iron the induced porosity may result in a constant intra and inter grain diffusion resistance [5-7].

\subsection{Temperature programmed reduction}

Kinetic analysis of gas solid reactions can be performed by various experimental methods. Reduction kinetics is usually studied under isothermal conditions but non-isothermal techniques, as Temperature Gravimetric Analysis (TGA) and Temperature Programmed Reduction (TPR), became more popular because the data are easier to process [8]. The simplicity and high sensitivity of TPR make it a very useful and commonly used method for the analysis of the kinetics of gas solid reactions [8]. However, a linear heating rate during reaction results into different reaction conditions during the conversion of the iron oxide sample. Furthermore the application of the TPR method in the reduction of iron oxide performed by many different researchers resulted in an activation energy in the range of 54-117 kJ/mole (Table 5.1). This can be attributed to the different experimental conditions applied and the samples used $[8,9]$. 
Table 5.1: Comparison of kinetic models and activation energies for the reduction of $\mathrm{Fe}_{2} \mathrm{O}_{3}$ found in literature.

\begin{tabular}{|c|c|c|c|c|}
\hline Author & Reduction step & & Reduction mechanism & $\mathrm{E}(\mathrm{kJ} / \mathrm{mol})$ \\
\hline Sastri et al. [10] & $\mathrm{Fe}_{2} \mathrm{O}_{3} \rightarrow \mathrm{Fe}$ & iso & 3D phase boundary & $57-73$ \\
\hline \multirow[t]{2}{*}{ Shimokawabe[11] } & $\mathrm{Fe}_{2} \mathrm{O}_{3} \rightarrow \mathrm{Fe}_{3} \mathrm{O}_{4}$ & TPR & Random nucleation & $74-117$ \\
\hline & $\mathrm{Fe}_{3} \mathrm{O}_{4} \rightarrow \mathrm{Fe}$ & & Phase boundary & $60-73$ \\
\hline \multirow[t]{2}{*}{ Tiernan et al. [8] } & $\mathrm{Fe}_{2} \mathrm{O}_{3} \rightarrow \mathrm{Fe}_{3} \mathrm{O}_{4}$ & CRTA $^{a)}$ & Phase boundary & 96 \\
\hline & $\mathrm{Fe}_{3} \mathrm{O}_{4} \rightarrow \mathrm{Fe}$ & & Avrami-Erofeev & $59-69$ \\
\hline \multirow[t]{2}{*}{ Tiernan [8] } & $\mathrm{Fe}_{2} \mathrm{O}_{3} \rightarrow \mathrm{Fe}_{3} \mathrm{O}_{4}$ & TPR & n.d. & 106 \\
\hline & $\mathrm{Fe}_{3} \mathrm{O}_{4} \rightarrow \mathrm{Fe}$ & & & 54 \\
\hline \multirow[t]{2}{*}{ Lin et al. [12] } & $\mathrm{Fe}_{2} \mathrm{O}_{3} \rightarrow \mathrm{Fe}_{3} \mathrm{O}_{4}$ & TPR & Unimolecular decay & 89 \\
\hline & $\mathrm{Fe}_{3} \mathrm{O}_{4} \rightarrow \mathrm{Fe}$ & & 2D-Avrami-Erofeev & 70 \\
\hline Wimmers et al. [13] & $\mathrm{Fe}_{3} \mathrm{O}_{4} \rightarrow \mathrm{Fe}$ & TPR & 3D-Avrami-Erofeev & 111 \\
\hline \multirow[t]{2}{*}{ McKewan [14] } & $\mathrm{Fe}_{2} \mathrm{O}_{3} \rightarrow \mathrm{Fe}$ & iso & 3D phase boundary & 58 \\
\hline & $\mathrm{Fe}_{3} \mathrm{O}_{4} \rightarrow \mathrm{Fe}$ & & 3D phase boundary & 57 \\
\hline Tokuda [5] & $\begin{array}{l}\mathrm{Fe}_{3} \mathrm{O}_{4}, \mathrm{Fe}_{2} \mathrm{O}_{3} \rightarrow \mathrm{Fe} \\
\mathrm{FeO} \rightarrow \mathrm{Fe}\end{array}$ & - & & $\begin{array}{l}54-67 \\
63\end{array}$ \\
\hline
\end{tabular}

This paragraph discusses the theory of the TPR experiment and the possibilities and limitations of TPR as an analytical method to determine the activation energy and the particle model describing the conversion rate of the solid particles as a function of the conversion $(f(\alpha))$.

\subsubsection{TPR-profile}

The kinetic modeling using a TPR-pattern is generally based on the conversion rate equation of a solid reacting with a gas to form another solid $[8,13,15$ 17].

$$
\frac{\mathrm{d} \alpha}{\mathrm{dt}}=\mathrm{k}(\mathrm{T}) \cdot \mathrm{f}(\alpha) \cdot \mathrm{f}_{2}(\mathrm{gas})
$$

Where $\alpha$ is the relative conversion, $\left.\alpha=\left(\mathrm{S}_{0}-\mathrm{S}\right) / \mathrm{S}_{0}\right)$ with $\mathrm{S}_{0}$ being the initial amount of reducible species and $S$ the current amount, $k(T)$ is the temperature dependent rate constant, $\mathrm{f}_{2}$ (gas) is a function accounting for the influence of the gas composition on the reduction rate and $f(\alpha)$ represents effect of the iron oxide conversion on the conversion rate (Table 5.2). The TPR curve is obtained by the integration of equation 5.1 . 


$$
\int_{0}^{\alpha} \frac{\mathrm{d} \alpha}{\mathrm{f}(\alpha)}=\mathrm{g}(\alpha)=\frac{\mathrm{A}}{\beta} \int_{\mathrm{T}_{0}}^{\mathrm{T}} \exp \left(\frac{-\mathrm{E}_{\mathrm{a}}}{\mathrm{R}_{\mathrm{g}} \mathrm{T}}\right) \mathrm{dT} \cdot \mathrm{f}_{2}(\text { gas })
$$

In which $\beta$ is the heating rate and $\mathrm{k}(\mathrm{T})$ is represented by the Arrhenius equation.

Table 5.2: Representation of $f(\alpha)$ and $g(\alpha)$ for possible controlling mechanisms for gas-solid reactions [15, 17].

\begin{tabular}{|c|c|c|c|}
\hline & Model Name & $f(\alpha)$ & $\mathrm{g}(\alpha)$ \\
\hline A & Random nucleation & $(1-\alpha)$ & $-\ln (1-\alpha)$ \\
\hline B & Contracting area & $(1-\alpha)^{1 / 2}$ & $2\left(1-(1-\alpha)^{1 / 2}\right)$ \\
\hline $\mathrm{C}$ & Contracting sphere & $(1-\alpha)^{2 / 3}$ & $3\left(1-(1-\alpha)^{1 / 3}\right)$ \\
\hline $\mathrm{D}$ & $\begin{array}{l}\text { Three-dimensional diffusion (Jander } \\
\text { diffusion) }\end{array}$ & $3(1-\alpha)^{2 / 3} /\left(2\left(1-(1-\alpha)^{1 / 3}\right)\right)$ & $\left(1-(1-\alpha)^{1 / 3}\right)^{2}$ \\
\hline $\mathrm{E}$ & Generalised $\mathrm{n}^{\text {th }}$ order & $(1-\alpha)^{\mathrm{n}}$ & $\mathrm{n}\left(1-(1-\alpha)^{1 / \mathrm{n}}\right)$ \\
\hline $\mathrm{F}$ & 3D Avrami-Erofeyev & $4(1-\alpha)(-\ln (1-\alpha))^{2 / 3}$ & $(-\ln (1-\alpha))^{1 / 4}$ \\
\hline $\mathrm{G}$ & Generalised Avrami- Erofeyev & $\mathrm{N}(1-\alpha)(-\ln (1-\alpha))^{(\mathrm{N}-1) / \mathrm{N}}$ & $(-\ln (1-\alpha))^{1 / n}$ \\
\hline
\end{tabular}

The functions shown in Table 5.2 represent mechanisms, in which the reaction at the reaction interface is rate determining ( $\mathrm{A}, \mathrm{B}$ and $\mathrm{C})$, diffusion through the material (D) is rate determining or in which nucleation processes (E,F and G) control the conversion rate. In the nucleation process the formation of nuclei (metal) accelerates the reaction due to the increased metal/metal oxide interface. Eventually the formation of metal will result in a decrease in the metal/metal oxide surface area and the reaction slows down.

Function $\mathrm{f}_{2}$ (gas) is often replaced by a constant when the experiments are performed with one feed and under differential conditions [8, 13, 18]. In most reduction studies with iron oxide the reduction with hydrogen is found to be of first order in hydrogen $[14,19]$. When differential conditions are applied in the reactor, the influence of the water formed on the reduction reaction will be minimum and is therefore neglected in the present analysis $[8,20,21]$.

The TPR-model can be derived when the hydrogen mass balance over the reactor is combined with the balance over the solid material (equation 5.1). This TPR model is also previously used by Malet [21]. The hydrogen mass balance is defined as follows: 


$$
\varphi \mathrm{C}_{\mathrm{H}_{2}, 0}=\varphi \mathrm{C}_{\mathrm{H}_{2}}+\mathrm{S}_{0}\left(\frac{\mathrm{d} \alpha}{\mathrm{dt}}\right)
$$

with $\varphi$ as the flow rate of the reducing gas and $\mathrm{S}_{0}$ the initial amount of reducible oxygen. If water is present in the reduction feed, $\mathrm{f}_{2}$ (gas) is equal to $\left(\mathrm{C}_{\mathrm{H}^{-}}\right.$ $\mathrm{C}_{\mathrm{H} 2 \mathrm{O}} / \mathrm{K}_{\mathrm{e}}$ ), in which $\mathrm{K}_{\mathrm{e}}$ is the equilibrium constant for the specific reduction reaction taking place. Combination of equation 5.1 with the hydrogen mass balance results into:

$$
\frac{\mathrm{d} \alpha}{\mathrm{dT}}=\frac{\mathrm{A} \cdot \mathrm{e}^{-\mathrm{Ea} / \mathrm{RT}} \mathrm{f}(\alpha)\left(\mathrm{C}_{\mathrm{H}_{2}, 0}-\frac{\mathrm{C}_{\mathrm{H}_{2} \mathrm{O}, 0}}{\mathrm{~K}_{\mathrm{e}}}\right)}{\beta+\frac{\beta \mathrm{S}_{0}}{\varphi} \mathrm{A} \cdot \mathrm{e}^{-\mathrm{Ea} / \mathrm{RT}} \mathrm{f}(\alpha)\left(1+\frac{1}{\mathrm{~K}_{\mathrm{e}}}\right)}
$$

Equations 5.1 and 5.4 represent the relative conversion rate obtained in a TPR experiment for a single reduction reaction. When a two step reduction process is expected, like the reduction of hematite via magnetite to iron, the values of both $\alpha$ and $\mathrm{S}_{0}$ have to be adjusted for each step.

\subsubsection{Determination of the activation energy}

Different methods are discussed in literature $[12,13,18,20,21]$ to determine the activation energy and the pre-exponential factor on the basis of 0 , combined with the experimentally obtained TPR data. Simple methods, like the Kissinger and Friedman method, assume that equation 5.1 provides a sufficient description of the reaction [15].

The Kissinger method is based on the assumption that the location of the rate maximum of a TPR experiment, or the peak in a d $(\alpha) / \mathrm{dT}$ versus temperature will shift when different heating rates are applied. The second derivative with respect to temperature at the rate maximum equals zero:

$$
\left\{\frac{\mathrm{d}}{\mathrm{dT}}\left(\frac{\mathrm{d} \alpha}{\mathrm{dT}}\right)\right\}_{\mathrm{T}=\mathrm{T}_{\max }}=0
$$


Combining 5.5 with 5.1 results in:

$$
\left\{\frac{\mathrm{d}}{\mathrm{dT}}\left(\frac{\mathrm{A}}{\beta} \mathrm{f}_{2} \cdot \mathrm{e}^{-\mathrm{E} / \mathrm{RT}} \mathrm{f}(\alpha)\right)\right\}_{\mathrm{T}=\mathrm{T}_{\max }}=0
$$

Rewriting this equation and assuming that water is not present in the feed and that differential conditions are applied in the system $\left(\mathrm{f}_{2}=\mathrm{C}_{\mathrm{H} 2,0}\right)$, results in:

$$
\ln \left(\frac{\beta}{\mathrm{T}_{\max }^{2}}\right)=-\frac{\mathrm{E}}{\mathrm{RT}_{\max }}+\ln \left(\frac{\mathrm{ARC}_{\mathrm{H}_{2,0}}}{\mathrm{E}}\right)+\ln \left(-\left(\frac{\mathrm{df}(\alpha)}{\mathrm{d} \alpha}\right)_{\mathrm{T}=\mathrm{T}_{\max }}\right)
$$

Plots of $\ln \left(\mathrm{T}_{\max }^{2} / \beta\right)$ versus $1 / \mathrm{T}_{\max }$ (temperature programmed Arrhenius plot) give straight lines with a slope equal to $-\mathrm{E}_{\mathrm{a}} / \mathrm{R}$, from which the activation energy can be derived. The Kissinger method is indifferent towards the particle model describing the conversion rate of the solid particles $(\mathrm{f}(\alpha))$ if the value of $(\mathrm{df}(\alpha) / \mathrm{d} \alpha)_{\mathrm{T}=\mathrm{T}_{\max }}$ is constant for every heating rate. This is only true for models where $f(\alpha)$ is linear in $\alpha$ (Random nucleation, Table 5.2), but it holds for many models around typical conversion level at the rate maximum $(\alpha \sim 0.6)$ [15].

The Friedman method is applied to calculate the activation energy at desired degrees of conversion and is also based on the conversion rate of the solid given in equation 5.1. When assuming a constant value for $\mathrm{f}_{2}$ and taking natural logarithms on both sides of equation 5.1 gives:

$$
\ln \left(\beta \frac{\mathrm{d} \alpha}{\mathrm{dT}}\right)=-\frac{\mathrm{E}_{\mathrm{a}}}{\mathrm{RT}}+\ln \left(\mathrm{A} \cdot \mathrm{f}(\alpha) \mathrm{C}_{\mathrm{H}_{2,0}}\right)
$$

In this method the plot of $\ln (\beta \cdot \mathrm{d} \alpha / \mathrm{dT})$ versus $1 / \mathrm{T}$ results in a straight line at different constant values of $\alpha$, in which the slope of the line equals $-E_{a} / R$ from which $\mathrm{E}_{\mathrm{a}}$ can be determined. If the activation energy from the Friedman analysis varies with conversion, it indicates that no single model of the form of equation 5.1 describes the reaction kinetics over the whole $\alpha$ range [15]. 
Furthermore, the reduction mechanism can be determined by replacing $f(\alpha)$ with a mathematical representations of the reduction mechanisms (Table 5.2). The best fit of the experimental data with these different particle models using equation 5.1 should in this case represent the particle model applicable for the specific material used.

\subsection{Experimental set-up}

A packed bed set-up is constructed to perform the TPR and isothermal reduction studies. The set-up, procedure, materials and calculations will be discussed in this section.

\subsubsection{Set-up TPR}

A schematic representation of the set-up is shown in Figure 5.4. The reactor, a quartz tube (ID $4 \mathrm{~mm}, \mathrm{~L} 52 \mathrm{~cm}$ ) holds the sample. The sample is put between two pieces of quartz wool in the middle of the reactor. The reactor is placed in an oven, which can be heated to a maximum temperature of $120{ }^{\circ} \mathrm{C}$. The oven is controlled in such a way that a temperature profile during the experiment is obtained. The temperature of the sample is measured with two thermocouples, both placed in the reactor just above and below the sample bed. The average temperature is taken as the reaction temperature and the difference between the upper and lower temperature was never more than $4{ }^{\circ} \mathrm{C}$. Linear heating rates up to $15{ }^{\circ} \mathrm{C} / \mathrm{min}$ resulted in a good linear temperature profiles and higher heating rates are therefore not applied. Mass flow controllers regulated the required hydrogen and nitrogen flow. In all experiments the total flow is set to $82 \mathrm{ml} / \mathrm{min}$ (STP) with a $\mathrm{H}_{2} / \mathrm{N}_{2}$ mixture of $50 \mathrm{vol} \%$. In most papers a lower concentration of hydrogen in the gas feed is used [8, 13, 15-17]. However the high hydrogen concentration is beneficial to obtain minor effects of the water production on the reduction rate of the iron oxide and is also used by Wimmers et.al. [13]. The gas product is cooled in a small water cooler and analyzed by a $\mathrm{H}_{2}$ TCD analyzer. 


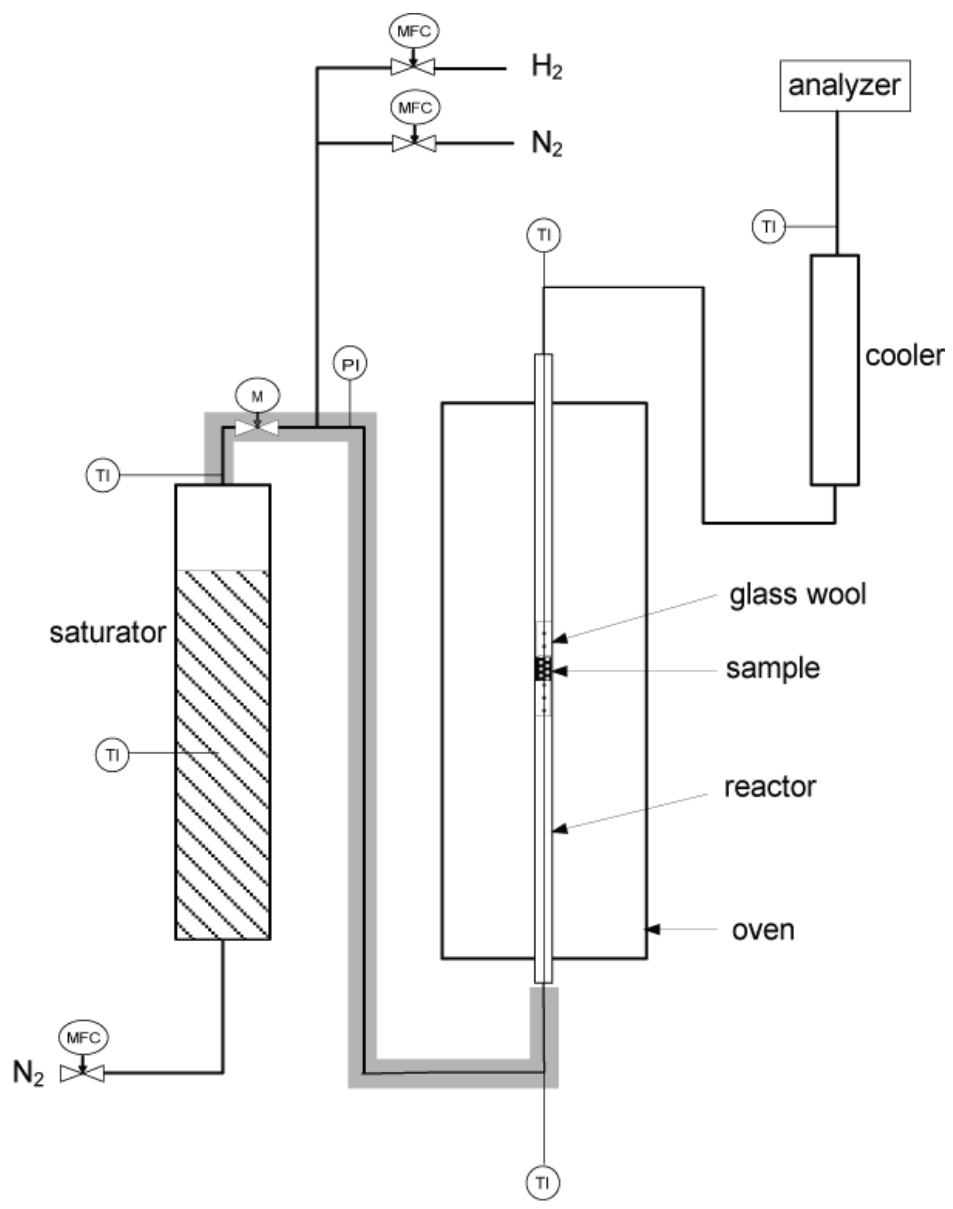

Figure 5.4: Overview of the TPR set-up

\subsubsection{Set-up isothermal reduction}

The reactor is a quartz glass tube, consisting of two parts. The first part is a capillary quartz tube (ID $0.8 \mathrm{~mm}, \mathrm{~L} 25 \mathrm{~cm}$ ), which is connected to the sample holder (ID $4 \mathrm{~mm}, \mathrm{~L} 1 \mathrm{~cm}$ ). The second part consists of a similar capillary tube (ID $0.8 \mathrm{~mm}, \mathrm{~L}$ $25 \mathrm{~cm}$ ), which is connected to a glass piece to make a gas tight connection with the sample holder (Figure 5.5). The sample is placed between two small pieces of quartz glass wool in the sample holder. Two thermocouples are positioned on the reactor wall at the same level as the sample. Gas is supplied to the reactor with a flow of $82 \mathrm{ml} / \mathrm{min}$ (STP). The flows of nitrogen and hydrogen are controlled by mass flow controllers. During reduction a hydrogen concentration in the gas feed of 30 vol $\% \mathrm{H}_{2}$ in $\mathrm{N}_{2}$ is applied. When the oxidation is performed, nitrogen is fed along a water saturator 
resulting in a stable water content in the gas phase. The temperature of the saturator was set to $60^{\circ} \mathrm{C}$ to obtain a gas feed with $10 \mathrm{vol} \% \mathrm{H}_{2} \mathrm{O}$ in $\mathrm{N}_{2}$. A bypass is used to stabilize the analyzer with the $\mathrm{H}_{2} / \mathrm{N}_{2}$ mixture before the reaction is started. Two three way valves, one before and one after the reactor, can switch the gas flow between the bypass and the reactor.

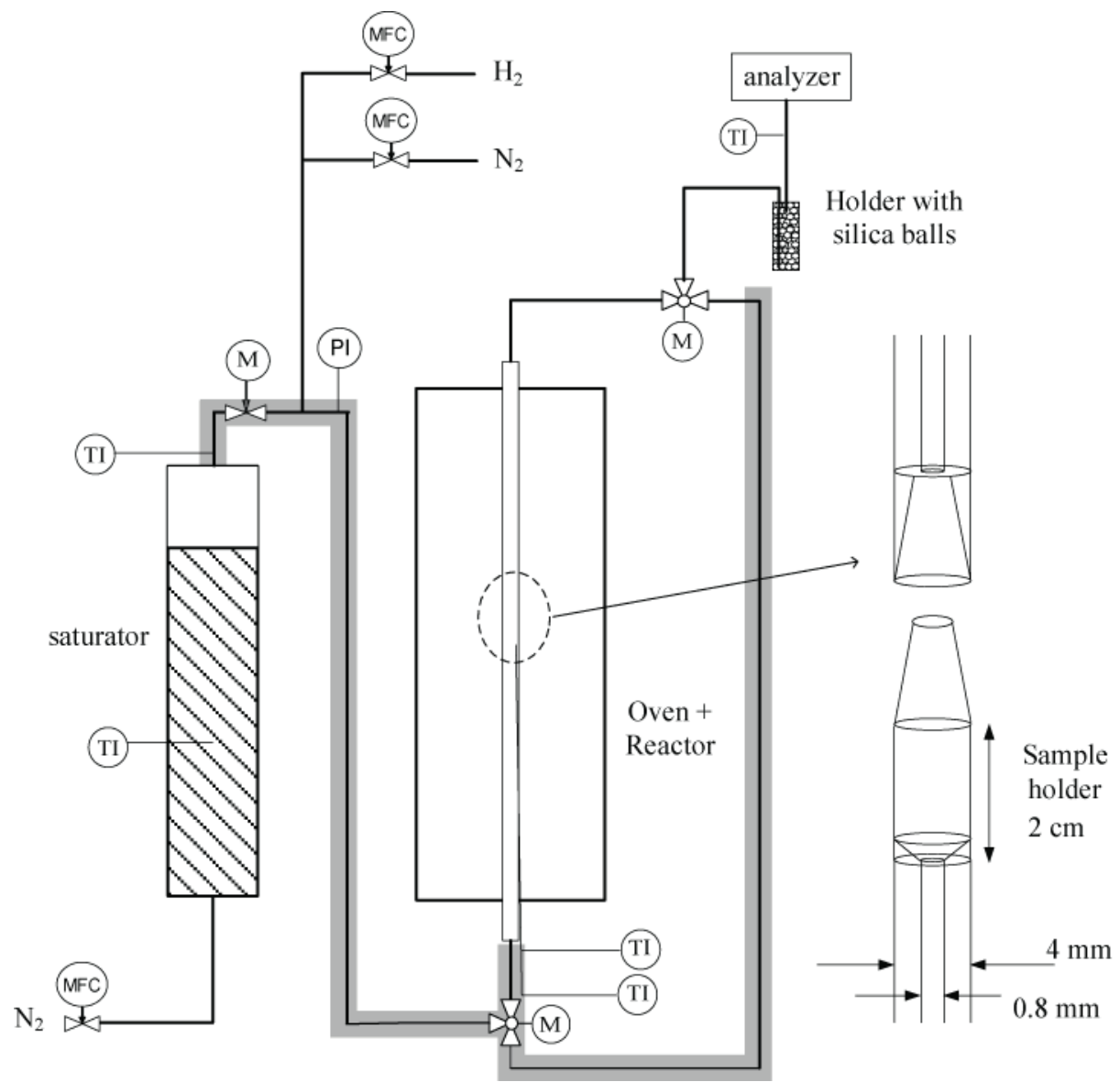

Figure 5.5: Overview of the isothermal set-up with a more detailed description of the sample holder.

The reactor is placed in an electric oven at a constant reaction temperature. All tubings leading to and from the reactor are traced at a temperature of about $140{ }^{\circ} \mathrm{C}$ to prevent condensation of water. The water in the gas leaving the reactor is stripped by feeding it to a small container with small silica balls. Replacing the water cooler by this container reduced the dead space in the set-up and therefore resulted in better 
measurements. This is especially important when the reaction is conducted under isothermal conditions, as will be explained later. Finally, the gas is analyzed in an online analyzer, which measures the $\mathrm{H}_{2}$ concentration in the gas phase.

\subsubsection{Materials}

Three types of iron oxide were used in the TPR and isothermal experiments. The composition is determined with XRF analysis and shown in Table 5.3.

Table 5.3: Composition of the iron oxides used

\begin{tabular}{llll}
\hline & $\begin{array}{l}\mathrm{BIC} \\
(\mathrm{wt} \%)\end{array}$ & $\begin{array}{l}\mathrm{BF} \\
(\mathrm{wt} \%)\end{array}$ & $\begin{array}{l}\text { Pure } \\
(\text { wt \%) }\end{array}$ \\
\hline $\mathrm{Fe}_{2} \mathrm{O}_{3}$ & 87.9 & 95.1 & 99.9 \\
$\mathrm{Cr}_{2} \mathrm{O}_{3}$ & 9.2 & 0.02 & \\
$\mathrm{CuO}$ & 2.7 & 0.08 & \\
$\mathrm{SiO}_{2}$ & & 2.21 & \\
$\mathrm{MgO}$ & & 1.47 & \\
$\mathrm{CaO}$ & & 0.43 & \\
$\mathrm{Al} \mathrm{O}_{3}$ & 0.03 & 0.30 & \\
$\mathrm{MnO}$ & 0.27 & 0.09 & \\
$\mathrm{~K}_{2} \mathrm{O}$ & & 0.04 & \\
\hline
\end{tabular}

\subsubsection{Procedure}

\section{TPR}

The sample is put between two pieces of quartz wool in the quartz reactor tube (ID $4 \mathrm{~mm}$ ). The amount of material is calculated to obtain a constant $\mathrm{P}$ value (section 5.5.1) in the experiments at different heating rates. The parameter $\mathrm{P}$ is an experimental parameter which should be kept constant to avoid unwanted experimental artifacts in the results. The heating rates applied are between $3-15 \mathrm{~K} / \mathrm{min}$ and according to 5.14 large amounts of sample material are required at low heating rates. Differential conditions ( $<3 \%$ decrease in the $\mathrm{H}_{2}$ concentration) are met in the TPR set-up. At the start of the experiment the feed gas mixture is fed to the reactor and the product gas goes unreacted to the analyzer as no reaction is expected at room temperature. The temperature ramp is started when the hydrogen analyzer is stabilized at $50 \mathrm{vol} \% \mathrm{H}_{2}$. 


\section{Isothermal reduction}

The reduction is performed in such a way that there can be no starvation of the reactant gas and to ensure differential conditions a decrease in the hydrogen concentration of less than $15 \%$ is allowed. This can only be achieved with a small amount of sample material (10-15 mg) at the applied gas feed and temperatures. During heating up, the reactor is flushed with nitrogen. After heating-up the feed gas goes through the bypass to the analyzer to stabilize the hydrogen concentration. The experiment is started when the feed gas is switched from the bypass to the reactor. During the reduction a decrease in the hydrogen concentration is caused by the reduction, but also by the nitrogen present in the reactor before the experiment is started. The decrease in hydrogen concentration due to the nitrogen present in the reactor between the two three-way valves, is taken into account by performing a "zero" experiment. In this experiment the decrease in the hydrogen concentration is measured when only quartz wool is present in the reactor. This "zero" experiment is used to calculate the hydrogen decrease caused by the actual reduction reaction in the reactor.

The "zero" experiment is not required in the steam oxidation as the hydrogen concentration will increase, starting from zero. The oxidation is performed with a water content of $10 \mathrm{vol} \% \mathrm{H}_{2} \mathrm{O}$, differential conditions at the onset of oxidation could not be met (maximal 30\% steam conversion at the onset). Increasing the water concentration is possible to about $20 \mathrm{vol} \%$, but more water in the gas phase results in a less stable gas feed.

The reduction and oxidation of the iron oxide are recorded by measuring the change in the hydrogen concentration during reaction. The amount of hydrogen reacted (reduction) or the amount of hydrogen produced (oxidation) can be translated in a relative conversion of the iron oxide.

\subsubsection{Calculations}

\section{TPR}

The change in hydrogen concentration can be used to calculate the conversion of the iron oxide sample. For every mole of hydrogen that reacts with the iron oxide one mole of oxygen is removed from the sample (reduction). The nitrogen concentration and flow is used to determine the hydrogen flow in the product gas. 


$$
\frac{\mathrm{dO}}{\mathrm{dt}}(\mathrm{t})=\left(\varphi \mathrm{H}_{2, \text { in }}-\frac{\varphi \mathrm{N}_{2}}{\left(100-\left[\mathrm{H}_{2}\right](\mathrm{t})\right)}\left[\mathrm{H}_{2}\right](\mathrm{t})\right) \frac{\mathrm{P}}{\mathrm{R}_{\mathrm{g}} \mathrm{T}}
$$

In which $\varphi \mathrm{H}_{2, \text { in }}(\mathrm{ml} / \mathrm{s})$ is the amount of hydrogen fed to the reactor, $\varphi \mathrm{N}_{2}(\mathrm{ml} / \mathrm{s})$ the nitrogen flow and $\left(\mathrm{H}_{2}\right)(\mathrm{t})$ is the measured hydrogen concentration $(\mathrm{vol} \%)$. The amount of oxygen from the sample which reacted with the gas phase can be used to calculate the conversion of the material $(\alpha)$ :

$$
\alpha(\mathrm{t})=\frac{\int_{\mathrm{t}_{0}}^{\mathrm{t}} \frac{\mathrm{dO}}{\mathrm{dt}} \mathrm{dt}}{\mathrm{S}_{0}}
$$

The amount of oxygen removed in a certain time interval $\left(t_{0}=0\right.$ to $\left.t=t\right)$ is divided by the initial amount of reactive oxygen present in the sample $\mathrm{S}_{0}$. $\mathrm{S}_{0}$ is based on the amount of oxygen that can participate in the redox cycle between $\mathrm{Fe}_{2} \mathrm{O}_{3}$ and $\mathrm{Fe}$. The relative conversion rate of the iron oxide $(\mathrm{d} \alpha / \mathrm{dt})$ is equal to the change in the relative conversion $(\mathrm{d} \alpha)$ calculated over a certain time step $(\mathrm{dt})$.

A temperature ramp is applied in the TPR experiment. The temperature at which the reaction is taking place needs to be coupled to the proper conversion rate. This can only be done when the retention time between the reactor and the analyzer is measured. The retention time can then be used to relate the temperature to the conversion rate at that temperature:

$$
\mathrm{T}_{\mathrm{act}}=\mathrm{T}(\mathrm{t})-\tau \beta
$$

In which $T(t)$ is the measured temperature at $t=t$ and $\beta$ the heating rate in the experiment. $T_{\text {act }}$ is the reaction temperature for the measured hydrogen concentration at time $\mathrm{t}$.

\section{Isothermal}

The calculations applied under isothermal conditions are similar to the calculations applied in the TPR experiments. During reduction however the "zero" experiment needs to be included in the calculation of the conversion rate. From the "zero" experiment the measured consumption of hydrogen caused by the nitrogen 
present in the reactor at the onset of the reaction is calculated. The measured hydrogen consumption during the experiment using iron oxide should be corrected with the "zero" experiment to obtain the amount of hydrogen which reacted with the iron oxide. Therefore the oxygen removal rate during reduction at a certain time $(t)$ in the experiment is:

$$
\frac{\mathrm{dO}}{\mathrm{dt}}(\mathrm{t})=\left(\varphi \mathrm{H}_{2, \text { in }}-\left(\frac{\varphi \mathrm{N}_{2}}{\left(100-\left[\mathrm{H}_{2}\right](\mathrm{t})\right)}\left[\mathrm{H}_{2}\right](\mathrm{t})-\varphi \mathrm{H}_{2, \text { zero }}(\mathrm{t})\right)\right) \frac{\mathrm{P}}{\mathrm{R}_{\mathrm{g}} \mathrm{T}}
$$

In which $\varphi_{\mathrm{H} 2, \mathrm{zero}}(\mathrm{t})(\mathrm{ml} / \mathrm{s})$ is the consumption of hydrogen calculated from the "zero" experiment. For the oxidation the conversion rate is also based on the measured hydrogen concentration, now being produced from the steam fed to the reactor:

$$
\frac{\mathrm{dO}}{\mathrm{dt}}(\mathrm{t})=\left[\frac{\varphi \mathrm{N}_{2}}{\left(100-\left[\mathrm{H}_{2}\right](\mathrm{t})\right)}\left[\mathrm{H}_{2}\right](\mathrm{t})\right] \frac{\mathrm{P}}{\mathrm{R}_{\mathrm{g}} \mathrm{T}}
$$

For both reduction and oxidation equation 5.10 can be used to calculate the relative conversion in each time step. The amount of oxygen present in the $\mathrm{Fe}_{2} \mathrm{O}_{3}$ is used for the value of $\mathrm{S}_{0}$. Therefore $\alpha=1$ relates to a relative conversion of $\mathrm{Fe}_{2} \mathrm{O}_{3}$ to $\mathrm{Fe}$ in the reduction and vice versa for the oxidation. A full oxidation to $\mathrm{Fe}_{2} \mathrm{O}_{3}$ in the oxidation is thermodynamically impossible at the applied conditions and a relative conversion $\alpha=1$ will not be obtained in the experiments.

\subsection{Verification of the set-up}

\subsubsection{P parameter for TPR}

Malet et.al. [21] developed an important experimental parameter for a TPR experiment. The experimental parameter $P$ relates the heating rate $\beta(\mathrm{K} / \mathrm{min})$, the amount of reducible species $\mathrm{S}_{0}(\mathrm{~mol})$, the total gas flow $\Phi(\mathrm{ml} / \mathrm{min})$ and the concentration of the gaseous reactant $\mathrm{C}_{0}$ in the feed ( $\mathrm{mol} / \mathrm{ml}$ ). 


$$
\mathrm{P}=\frac{\beta \mathrm{S}_{0}}{\varphi_{v} \mathrm{C}_{0}}
$$

According to Malet the value of the experimental parameter P should be kept as low as possible; lower than $20 \mathrm{~K}$ and within the limits of the experimental possibilities. An increase in the experimental parameter $P$ results in an increase in the value of $\mathrm{T}_{\max }$ and in a broadening and distortion of the peaks. These changes affect the calculated value of the activation energy. To avoid this influence on the activation energy Malet concludes that the value of the experimental parameter P must be kept constant for TPR experiments performed with different linear heating rates. The value of experimental parameter $\mathrm{P}$ is kept constant by decreasing the amount of reducible species $S_{0}$ with the same ratio as the linear heating rate $\beta$ is increased.

To determine the influence of a changing value of parameter $\mathrm{P}$ experiments have been performed using different sample amounts, under identical conditions (Table 5.4).

Table 5.4: Results of experiments with different values of parameter $P$.

\begin{tabular}{|l|l|l|l|l|l|l|}
\hline Parameter $\mathrm{P}$ & $(\mathrm{K})$ & 45.5 & 30.5 & 15.2 & 11.5 & 7.5 \\
\hline M sample & $(\mathrm{mg})$ & 269.2 & 179.1 & 89.9 & 68.1 & 44.6 \\
\hline$\beta$ & $(\mathrm{K} / \mathrm{min})$ & 15.0 & 15.1 & 15.0 & 14.9 & 15.0 \\
\hline $\mathrm{T}_{\max }$ & $\left({ }^{\circ} \mathrm{C}\right)$ & 583 & 546 & 510 & 497 & 466 \\
\hline
\end{tabular}




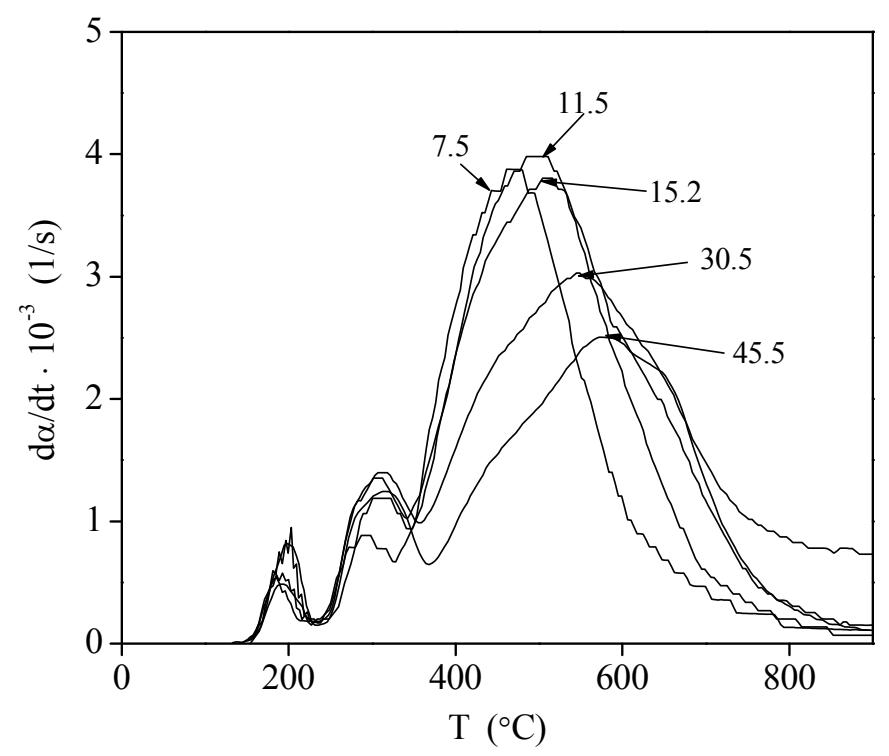

Figure 5.6: TPR-profiles of experiments with different values of the parameter $P$. Experimental conditions: $220<\mathrm{d}_{\mathrm{p}}<400 \mu \mathrm{m}, \varphi_{\mathrm{v}}=82 \mathrm{ml} / \mathrm{min}, \mathrm{CH}_{2,0}=\mathbf{2 . 0 . 1 0 ^ { - 5 }} \mathrm{mol} / \mathrm{ml}, \beta=15$ $\mathrm{K} / \mathrm{min}$ and $\mathrm{T}_{\text {final }}=900{ }^{\circ} \mathrm{C}$ for all experiments:

The TPR profiles in Figure 5.6 show that the peaks become more narrow with lower values of $\mathrm{P}$. This is because a smaller amount of sample will reduce in a shorter time, resulting in a narrow and high peak [20, 21]. These peaks at relatively low values of $\mathrm{P}$ are favoured because a more accurate value of $\mathrm{T}_{\max }$ can be determined. This implies that the value of the parameter $\mathrm{P}$ should be as small as possible. However, lower values of $\mathrm{P}$ result in an increase in the relative errors generated by the equipment and the method to process the data. Figure 5.6 also shows that for $\mathrm{P}>15.2$ $\mathrm{K}$ peak broadening takes place, which makes the determination of $\mathrm{T}_{\max }$ less accurate.

The importance in choosing a constant value of $\mathrm{P}$ for all experiments to avoid unwanted influences on $\mathrm{T}_{\max }$ is evident ref and in the experiments performed a $\mathrm{P}$ value of $11.5 \mathrm{~K}$ is used.

\subsubsection{Mass and heat transfer effects}

The experimental set-up (TPR and isothermal reduction) is constructed in such a way that the conversion rate measured is the overall conversion rate on a particle level. In Appendix B the absence of mass and heat transfer effects during reduction is checked based on experimental data and theoretical criteria. Theoretical criteria 
proved that inter and intra particle gas diffusion limitations and heat transport limitations are not expected to influence the measured conversion rates during TPR and isothermal reduction. Experiments using fresh porous BIC iron oxide, in which the particle diameter and the gas velocity (with constant weight hourly space velocity) are being varied, confirmed the absence of gas diffusion limitations.

Diffusional limitations may still occur when the porosity of the iron oxide is lower compared to the BIC iron oxide and when physically changes occur upon reduction, due to sintering for example. These diffusional limitations can be intra particle gas diffusion or solid state diffusion. Inter particle gas diffusion may also influence the measured conversion rate when particles stick together upon reduction.

The oxidation has not been investigated, but it is most likely that intra particle diffusion limitations exists as the structure densifies upon oxidation (see also Chapter $6)$.

\subsection{Results}

\subsubsection{TPR}

In Figure 5.7 the TPR profile for the BIC iron oxide is shown. As can be seen three peaks appear. The first peak can be related to the reduction of copper oxide present in the material. The second peak can be attributed to the reduction of $\mathrm{Fe}_{2} \mathrm{O}_{3}$ to $\mathrm{Fe}_{3} \mathrm{O}_{4}$ and finally the third peak is the reduction of $\mathrm{Fe}_{3} \mathrm{O}_{4}$ to $\mathrm{Fe}$ [22]. When pure iron oxide is reduced (Figure 5.8) one peak appears and a constant rate is measured when the temperature is higher than $620^{\circ} \mathrm{C}$. A slightly different particle size was used for the BIC iron oxide, which is expected to have a minimal effect on the results (Appendix B). 


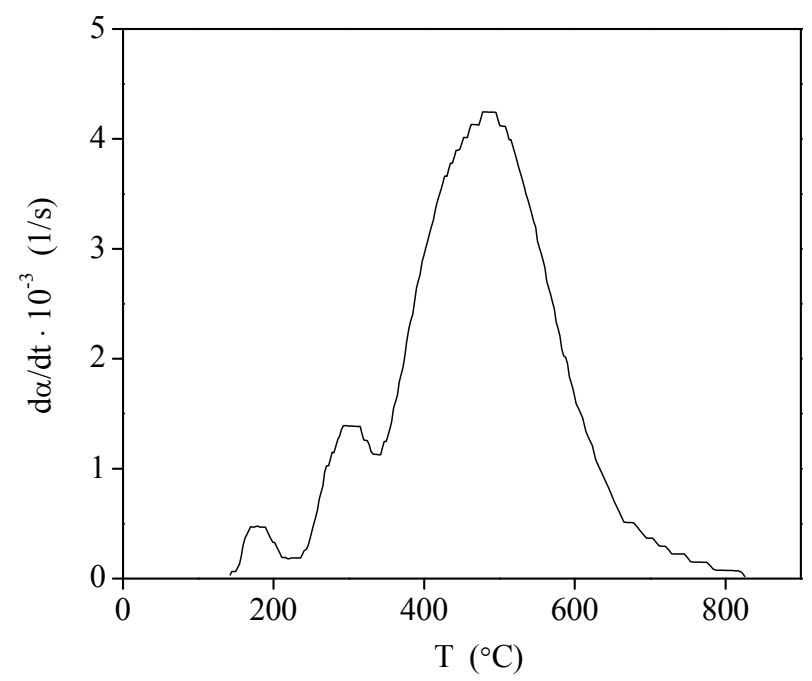

Figure 5.7: TPR profiles of the reduction of BIC iron oxide using a temperature ramp of

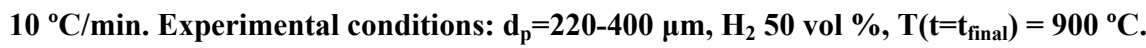

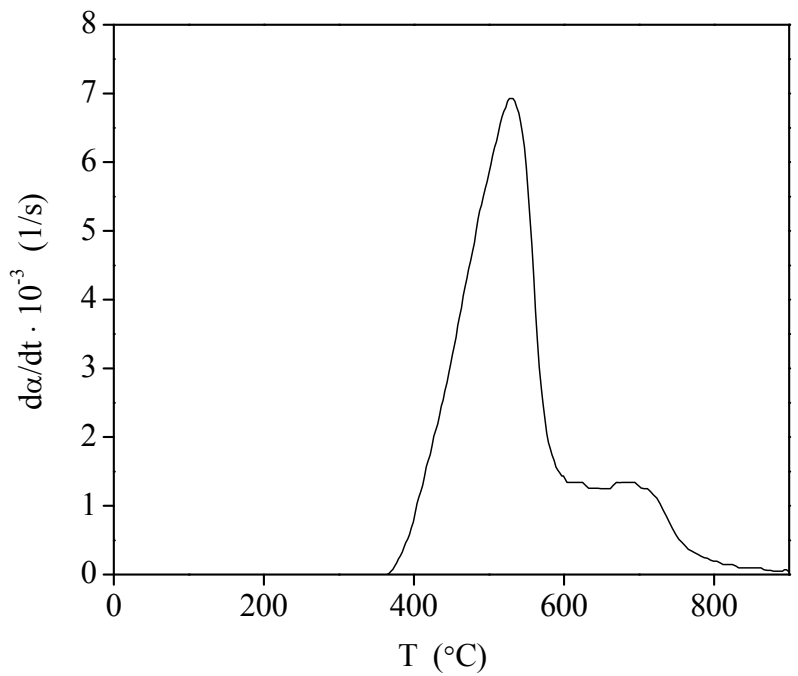

Figure 5.8: TPR profiles of the reduction of pure iron oxide using a temperature ramp of $10{ }^{\circ} \mathrm{C} / \mathrm{min}$. Experimental conditions: $d_{p}=125-220 \mu \mathrm{m}, \mathrm{H}_{2} 50$ vol \%, $T\left(t=t f_{\text {inal }}\right)=900{ }^{\circ} \mathrm{C}$.

The reduction of $\mathrm{Fe}_{2} \mathrm{O}_{3}$ to $\mathrm{Fe}_{3} \mathrm{O}_{4}$ is taking place in the temperature interval 240-340 ${ }^{\circ} \mathrm{C}$ as a separate peak from the other reduction reactions, which is probably caused by the presence of copper in the BIC iron oxide. Copper decreases the peak temperature of the reduction of $\mathrm{Fe}_{2} \mathrm{O}_{3}$ to $\mathrm{Fe}_{3} \mathrm{O}_{4}$ [22] and therefore becomes visible as a 
separate peak in the TPR. With pure iron oxide this reaction takes place at temperatures $>370{ }^{\circ} \mathrm{C}$ and is included in the peak in which all reduction reactions $\left(\mathrm{Fe}_{2} \mathrm{O}_{3} \rightarrow \mathrm{Fe}\right)$ are taking place. Another interesting observation is the constant reduction rate when pure iron oxide is used for temperatures higher than $+/-600{ }^{\circ} \mathrm{C}$. This remarkable observation has not been reported in literature and could be caused by sintering.

The obtained TPR profiles can be used to determine the activation energy of the reactions using the Kissinger or Friedman method (section 5.3.2). The particle model to describe the effect of the conversion on the reaction can be obtained by fitting the TPR profile to different particle models using equation 5.1. This is not discussed in this chapter as fitting of the different particle models did not result in univocal results [15].

\section{Kissinger method}

The Kissinger method is based on the shift of the rate maximum when different heating rates are applied under the same reaction conditions. The relative conversion of the material obtained at the maximum relative conversion rate (at $\mathrm{T}=$ $\mathrm{T}_{\max }$ ), is shown in Figure 5.9. It can be seen that the conversion degree is changing with the measured $\mathrm{T}_{\max }$, which indicates that the Kissinger method can result in erroneous results, especially with pure iron oxide.

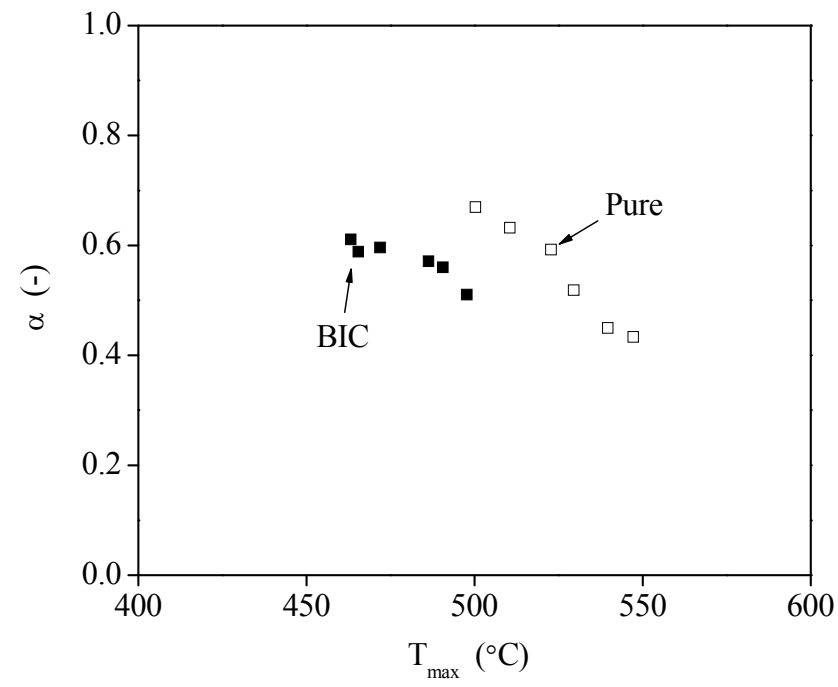

Figure 5.9: The relative conversion for different $T_{\max }$ of the reduction to iron (peak 3 for BIC iron oxide) measured at different heating rates. 
At temperatures below $570{ }^{\circ} \mathrm{C}$ the reduction takes place according to $\mathrm{Fe}_{2} \mathrm{O}_{3} \rightarrow$ $\mathrm{Fe}_{3} \mathrm{O}_{4} \rightarrow \mathrm{Fe}$, while for higher temperatures the formation of the intermediate, wustite, is expected in the reduction of magnetite to iron. The relative conversion of the material obtained at $\mathrm{T}_{\max }$ (Figure 5.9) shows that the reduction to Fe has already partly taken place at $\mathrm{T}_{\max }(\alpha>0.33)$ and that $\mathrm{T}_{\max }$ is below $570{ }^{\circ} \mathrm{C}$ for all experiments. Therefore it can be concluded that the activation energy determined with the TPR results, is the activation energy for the reduction of magnetite to iron.

Table 5.5: : Activation energy determined with the Kissinger method.

\begin{tabular}{lll}
\hline Peak BIC iron oxide & $\mathrm{Reaction}$ & $\mathrm{E}_{\mathrm{a}}(\mathrm{kJ} / \mathrm{mol})$ \\
\hline$\# 1$ & $\mathrm{CuO} \rightarrow \mathrm{Cu}$ & 53.1 \\
$\# 2$ & $\mathrm{Fe}_{2} \mathrm{O}_{3} \rightarrow 2 / 3 \mathrm{Fe}_{3} \mathrm{O}_{4}$ & 111.6 \\
$\# 3$ & $\mathrm{Fe}_{3} \mathrm{O}_{4} \rightarrow 3 \mathrm{Fe}$ & 144.6 \\
\hline Peak Pure iron oxide & & \\
$\# 1$ & $\mathrm{Fe}_{2} \mathrm{O}_{3} \rightarrow 2 \mathrm{Fe}$ & 180.0 \\
\hline
\end{tabular}

The obtained activation energies with the Kissinger method (Table 5.5) are rather high in comparison with the activation energies presented in literature (Table 5.1), especially for the reduction of the pure iron oxide. As already mentioned the use of the Kissinger method is questionable when the conversion degree at which $T_{\max }$ is found differs strongly with the temperature ramp applied, which is found for the pure iron oxide (Figure 5.9).

\section{Friedman method}

Contrary to the Kissinger method the Friedman method can be used to calculate the activation energy at different degrees of conversion of the iron oxide (Figure 5.10). A reliable activation energy could be determined for a relative conversion up to 0.6 . 


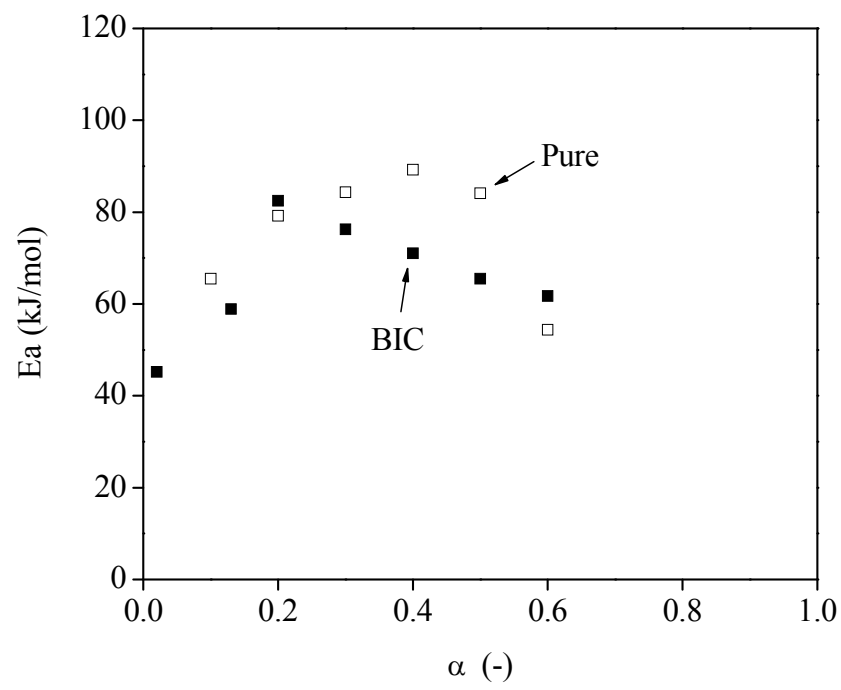

Figure 5.10: Calculated activation energy for different conversion degrees of the pure and BIC iron oxide based on the Friedman method.

The activation energy is changing with conversion for both iron oxides, especially for the BIC iron oxide, indicating that the reduction cannot be described by a single mechanism. Both iron oxides show an activation energy of about 70-90 $\mathrm{kJ} / \mathrm{mol}$ when the relative conversion of the material is between 0.2 and 0.5 , which is in correspondence with activation energies found in literature (Table 5.1). In this conversion range the reduction of magnetite to iron is taking place. A lower activation energy is expected at lower conversions for the reduction of $\mathrm{Fe}_{2} \mathrm{O}_{3}$ to $\mathrm{Fe}_{3} \mathrm{O}_{4}$ and for $\mathrm{CuO}$ to $\mathrm{Cu}$ (BIC iron oxide only).

\subsubsection{Isothermal reduction}

The reduction and oxidation are measured under isothermal conditions for $\mathrm{BIC}, \mathrm{BF}$ and a pure iron oxide. The different figures obtained by plotting the relative conversion rate versus different conversion degrees of the material will be discussed. In Appendix A the shape of the curve describing the behavior for different limiting cases and models has been discussed. It was shown that the inter- or intra grain diffusion limitation in the GPM or intra particle diffusion limitation in the SCM always results in a convex shape. In all other cases (concave shape) the overall reaction is limited by a core reaction or mass transport through the gas film. The conversion on the $\mathrm{x}$-axis represents the relative conversion of $\mathrm{Fe}_{2} \mathrm{O}_{3}$ to $\mathrm{Fe}$. When all reactions in between proceed in such a way that only two iron oxide phases are present 
at one and the same time, the relative conversion corresponds with the following phases: $\alpha=0.11$ for $\mathrm{Fe}_{3} \mathrm{O}_{4}, \alpha=0.33$ for $\mathrm{Fe}_{1-\mathrm{y}} \mathrm{O}$ and $\alpha=1$ for $\mathrm{Fe}$.

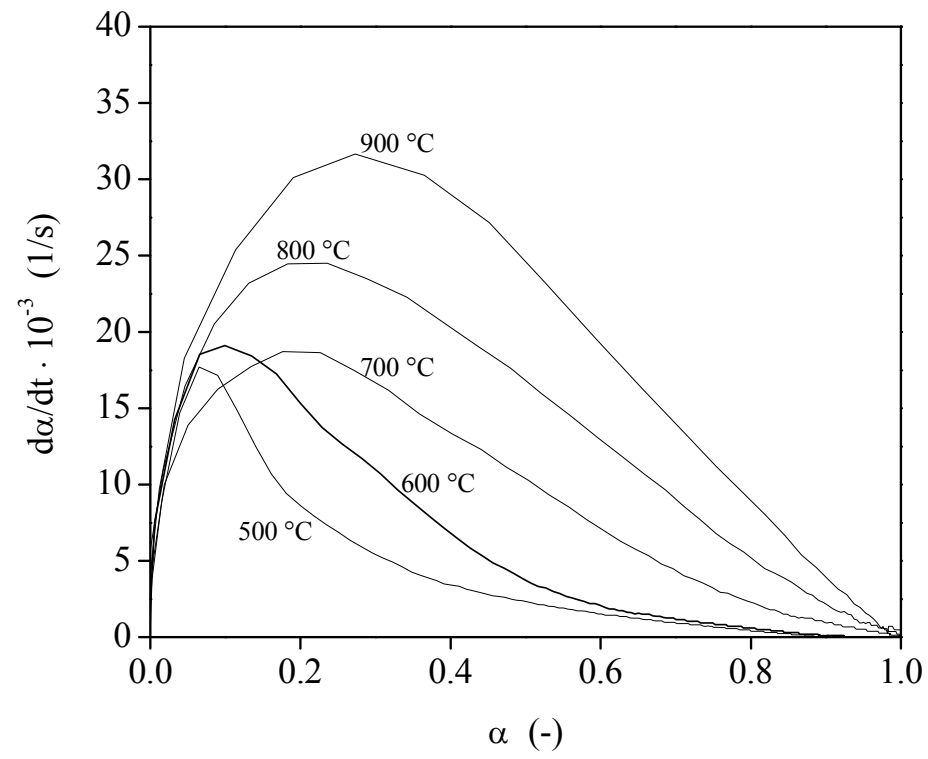

Figure 5.11: Relative conversion rate of the reduction of $B I C$ iron oxide $\left(d_{p}=125-200\right.$ $\mu \mathrm{m})$.

Figure 5.11 shows the conversion rate versus the relative conversion at different temperatures when BIC iron oxide is reduced. The initial increase in the conversion rate is mostly an artifact of the set-up. The time required for the analyzer to measure the actual decrease in hydrogen concentration is about 20 seconds. This is the same for all experiments performed at different temperatures, and therefore the actual conversion rate is measured at a higher conversion when the temperature is high. When a relative conversion of 0.11 is obtained the reduction of $\mathrm{Fe}_{2} \mathrm{O}_{3}$ to $\mathrm{Fe}_{3} \mathrm{O}_{4}$ is likely to be completed. This reaction is of no importance in the steam-iron process as the formation of $\mathrm{Fe}_{2} \mathrm{O}_{3}$ does not take place in the cyclic reaction. Therefore missing information from the first 20 seconds of the reduction experiment is of less concern.

The conversion rate for the porous BIC iron oxide is increasing with temperature, which can be expected from a normal Arrhenius dependency of the chemical reaction rate constant. The shape of the curve changes with temperature; the conversion rate is limited by gas or solid state diffusion resistance, as observed from the convex shape of the figure (Appendix A) at $500^{\circ} \mathrm{C}$ and $600{ }^{\circ} \mathrm{C}$. This convex shape 
becomes less pronounced at temperatures above $700{ }^{\circ} \mathrm{C}$. It is striking that the reaction becomes more limited by a diffusion resistance with decreasing temperature. Normally a low temperature is selected to measure the chemical reaction as in this case the reaction rate is low and therefore controls the overall rate of reaction. During reduction a product layer is formed through which solid state diffusion or gas diffusion needs to take place to continue the reduction. Solid state diffusion is highly temperature dependent and can explain the high diffusion resistance at these low temperatures $[5,6]$. Furthermore, below $570{ }^{\circ} \mathrm{C}$ magnetite is directly reduced to iron, while at higher temperatures the intermediate wustite is formed before further reduction to iron takes place. The formation of an iron layer upon reduction can enhance diffusion limitations significantly [5].

The reduction behaviour of the non-porous BF material (Figure 5.12) shows a much lower conversion rate compared to the BIC iron oxide and pure iron oxide (Figure 5.13), partly due to the lower porosity of these iron oxides. The presence of $\mathrm{SiO}_{2}$ in the $\mathrm{BF}$ iron oxide is expected to considerably lower the reducibility of the iron oxide, due to the slower solid state diffusion in the iron oxide and the formation of iron silicates. The iron silicate formation results in a low porosity of the material. The addition of $\mathrm{CaO}$ can prevent the $\mathrm{SiO}_{2}$ to combine with the iron oxide, especially when the $\mathrm{CaO} / \mathrm{SiO}_{2}$ ratio is larger than 1 , which is not the case for the $\mathrm{BF}$ iron oxide $[1,5]$.

In the experiment with $\mathrm{BF}$ iron oxide at $600{ }^{\circ} \mathrm{C}$ the maximum conversion rate is measured after about 130 seconds (instead of $+/-20$ seconds), which shows that the initial conversion rate increase is at this temperature not only caused by the experimental method. This indicates that a particle model, predicting an initial increase in the conversion rate, like the crackling core model (Appendix A) could be applied at this temperature. At higher reduction temperatures the increase in conversion rate with increasing relative conversion of the material is not evident from the experimental results.

For a reduction temperature above $700{ }^{\circ} \mathrm{C}$ two regimes can be observed for the $\mathrm{BF}$ and pure iron oxide; the reaction is initial controlled by the chemical reaction, while with increasing relative conversion a diffusion resistance becomes more pronounced, which can be seen from the convex shape of the curve at high relative conversion [23]. For example, Figure 5.12 and Figure 5.13 show that at $\alpha=0.55$ the conversion rate becomes limited by intra particle gas diffusion or solid state diffusion when a temperature of $700{ }^{\circ} \mathrm{C}$ is applied. The conversion rate is less influenced by the conversion of the particle when the reduction is conducted at $600{ }^{\circ} \mathrm{C}$, which can only 
be explained by the formation of a porous iron layer upon reduction at this temperature.

The time to reduce the iron oxide at $600{ }^{\circ} \mathrm{C}$ is much shorter compared to the reduction at $700{ }^{\circ} \mathrm{C}$ for both the $\mathrm{BF}$ and pure iron oxide. Tokuda [5] reported about this peculiarity in the reduction of iron oxide and described that in the temperature range of 650 to $750{ }^{\circ} \mathrm{C}$ the reduction rate can be delayed. In our experiments the time to finalize the reduction for the pure iron oxide is 23.4 minutes at $700{ }^{\circ} \mathrm{C}$, while a reduction time of 13.6 and 5.9 minutes at respectively 600 and $800{ }^{\circ} \mathrm{C}$ is found. This delaying effect is attributed to the sintering of reduced particles or entrapping of wustite in the reduced iron layer, which obstructs the intra particle gas diffusion, or the formation of dense wustite which can retard the reduction [5].

It is reported in literature that the porosity of the iron formed from wustite depends on the vacancy concentration in the wustite phase [1] and the impurity concentration in the material [5]. An increased impurity concentration and/or an increased vacancy concentration in the wustite phase can both result in a more porous iron. The vacancy concentration in the wustite phase depends on temperature and will increase with increasing temperature. This could explain why the diffusion limitation starts at a conversion of 0.55 at $700{ }^{\circ} \mathrm{C}$ and at 0.68 at $900{ }^{\circ} \mathrm{C}$. 


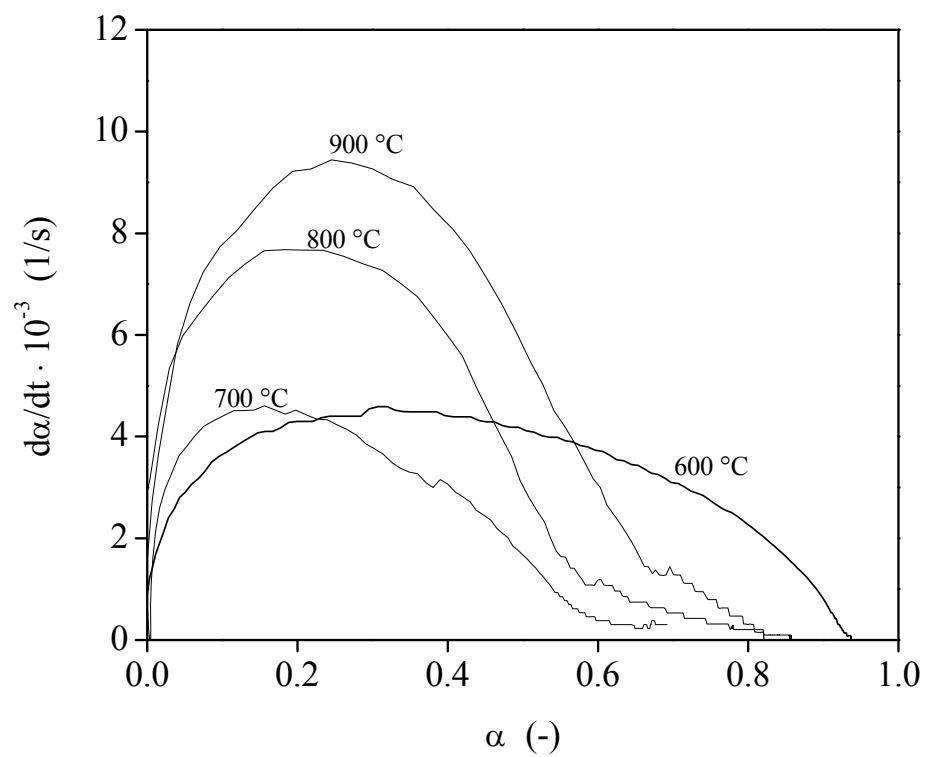

Figure 5.12: Relative conversion rate of the reduction of $B F$ iron oxide $\left(d_{p}=125-200 \mu m\right)$.

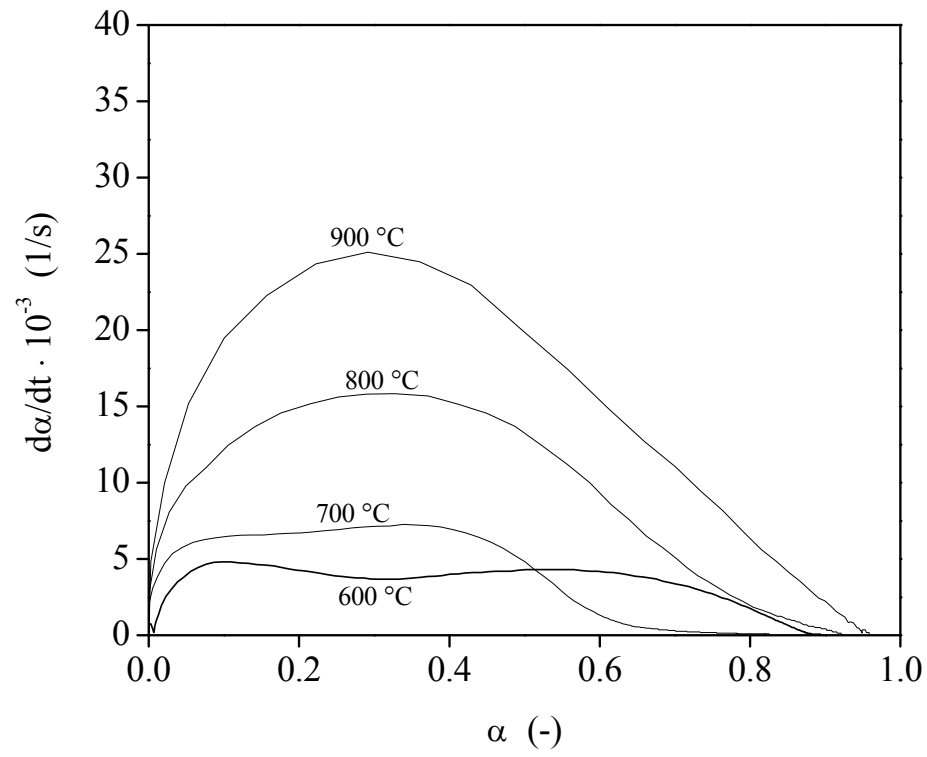

Figure 5.13: Relative conversion rate of the reduction of pure iron oxide $\left(d_{p}=125-200\right.$ $\mu \mathrm{m})$.

The reduction of pure iron oxide is performed under the same conditions with an increased particle size to see whether the effect observed at $700{ }^{\circ} \mathrm{C}$ is due to inter 
grain diffusion limitations. However exactly the same results are obtained with a particle size of 300-355 $\mu \mathrm{m}$. Although the surface area is low for the pure iron oxide, it apparently has a porosity which is high enough to enable gas transport to the grains, which are of similar size when the same material is used. When the conversion rate is determined at the grain level instead of a particle level, a similar reduction rate can be expected when particles with a different size are used.

\section{Activation energy}

The activation energy is determined by plotting the natural logarithm of the measured conversion rate $(\ln (\mathrm{d} \alpha / \mathrm{dt}))$ at a certain relative conversion versus the inverse reduction temperature $(1 / T)$. The slope of the obtained graph represents the $-E_{a} / R$, from which the activation energy can be determined. The experiments at $600{ }^{\circ} \mathrm{C}$ and lower are not incorporated in the determination of the activation energy, as a different reaction pathway probably takes place.

Figure 5.14 shows an increase in the activation energy with increasing relative conversion for the BF and Pure iron oxide, especially at a relative conversion higher than 0.6. Szekely [2] and Tokuda [5] reported that the activation energy is very high when the process becomes limited by solid state diffusion. Therefore the strong increase in the activation energy $(\alpha=0.6)$ could indicate that solid state diffusion controls the reduction rate in this region for the pure and $\mathrm{BF}$ iron oxide. The solid state diffusion in our experiments can be the diffusion of iron ions in wustite $\left(E_{a}\right.$ 125-138 $\mathrm{kJ} / \mathrm{mol}$ ) or oxygen ions in iron $[5,6]$. The activation energy calculated at low conversions $(\alpha<0.2)$ is less accurate as the onset of the reaction is influenced by the experimental method applied and is therefore not shown in the figure. 


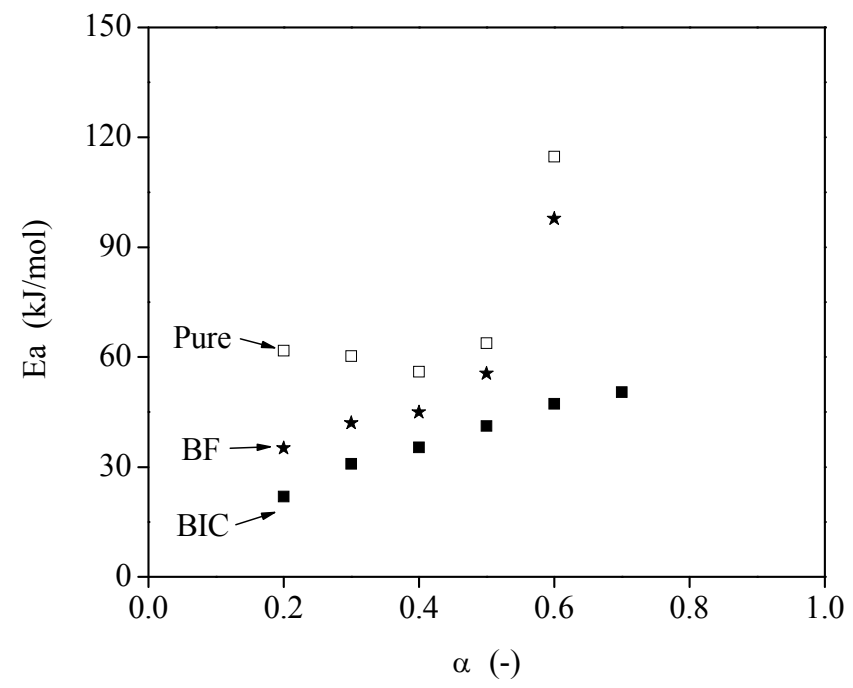

Figure 5.14: Activation energy for different relative conversions obtained under isothermal conditions.

\section{Particle models in the reduction}

The conversion-time relation of the reduction of BIC iron oxide could be fitted with the simple pseudo homogeneous model (Figure 5.15) and the results of the fit parameter $\left(\mathrm{k}_{\mathrm{v}}\right)$, are shown in Table 5.6. The activation energy, determined from this data is $33.1 \mathrm{~kJ} /$ mole, which corresponds well with the activation energy shown in Figure 5.14. Fitting the conversion-time results of the reduction of $\mathrm{BF}$ and pure iron oxide requires a more complex model, like the crackling core model. The crackling core model can be fitted to all conversion time results obtained in the set-up when besides $\omega, \alpha_{i}$ is also used as fit parameter. The value of $\alpha_{i}$ in the crackling core model is expected to be around 0.33 if the crackling reaction is the reduction of magnetite to wustite. However no such trends in the resulting fit parameters could be found, which makes interpretation of the obtained fit parameters difficult. Probably the physical changes, as a result of sintering and the formation of iron in the particle during reduction described in the previous sections make data fitting to a single model difficult. 


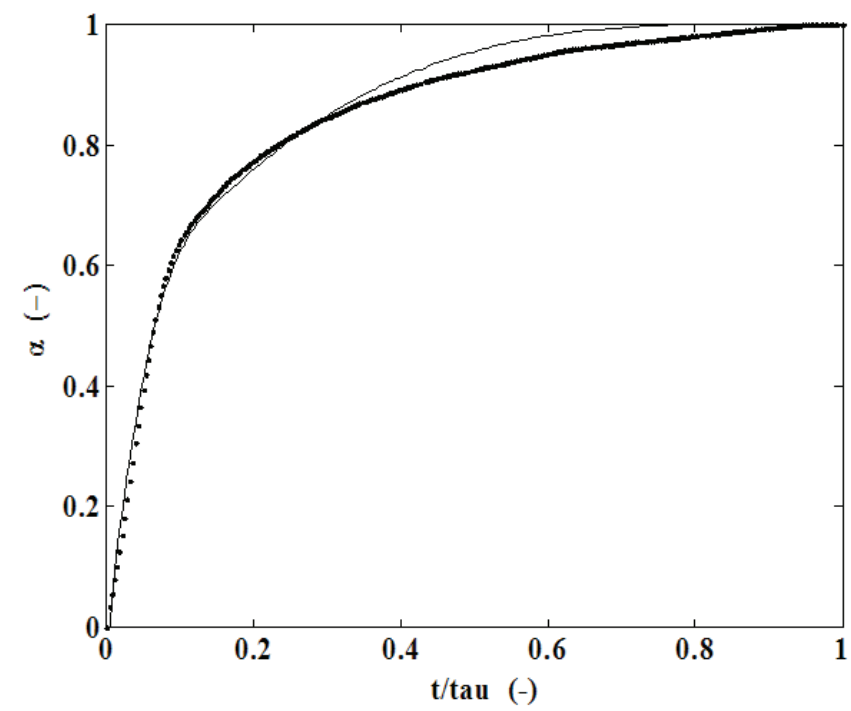

Figure 5.15: Experimental time-conversion relation for the BIC iron oxide and the fit curves obtained using pseudo homogeneous model at $700^{\circ} \mathrm{C}$. Fit parameters are given in Table 5.6.

Table 5.6: Fit results of fitting the reduction of BIC iron oxide with the pseudo homogeneous model.

\begin{tabular}{ll}
\hline $\mathrm{T}\left({ }^{\circ} \mathrm{C}\right)$ & $\mathrm{k}_{\mathrm{v}}, \mathrm{n}=1$ \\
\hline 900 & $2.94 \cdot 10^{-2}$ \\
800 & $2.29 \cdot 10^{-2}$ \\
700 & $1.22 \cdot 10^{-2}$ \\
500 & $0.52 \cdot 10^{-2}$ \\
\hline
\end{tabular}

The slow reduction to iron due to diffusional limitations in the particle are of less concern in the steam-iron process with pyrolysis oil as the cycle is performed mainly between the magnetite and wustite phase. In which case the relative conversion of the iron oxide will be between 0.11 and 0.33 . In Figure 5.16 the conversion-time relation is shown for the reduction of all three iron oxides at $800{ }^{\circ} \mathrm{C}$ below a relative conversion of 0.4 . In the first 20 seconds the increase in conversion is strongly influenced by the set-up and is not represent able for the reduction reaction itself. The conversion-time relation approximates a linear relation for all iron oxides when the relative conversion is between magnetite $(\alpha=0.11)$ and wustite $(\alpha=0.33)$ when pure hydrogen is used as reducing gas. This indicates that a simple model like the pseudo 
homogeneous model can predict the conversion-time relation in this conversion range for all tested iron oxides.

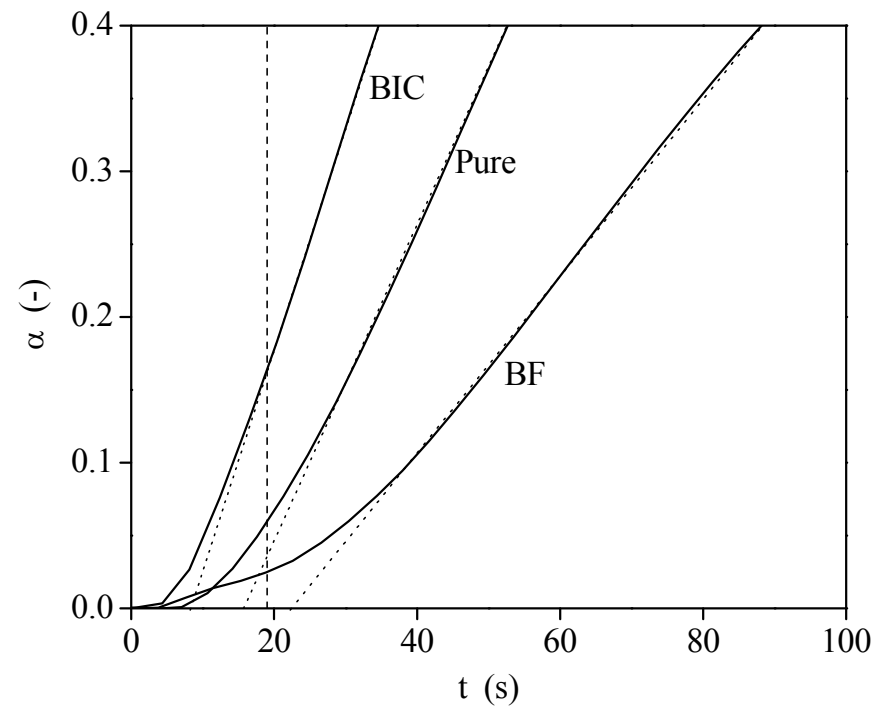

Figure 5.16: Conversion-time relation for the reduction of BIC, BF and pure iron oxide with hydrogen.

When approaching the maximum conversion, diffusional effects will influence the overall measured conversion rate, especially when non-porous iron oxide is reduced. The maximum relative conversion will be lower when $\mathrm{H}_{2} \mathrm{O}$ is added to the hydrogen gas feed, based on thermodynamics. The conversion-time relation of the reduction of magnetite to wustite is therefore expected to deviate from linearity when the maximum relative conversion of the iron oxide decreases.

\subsubsection{Isothermal oxidation}

The oxidation of the reduced iron oxide is conducted with a $10 \mathrm{vol} \% \mathrm{H}_{2} \mathrm{O}$ in $\mathrm{N}_{2}$ mixture. The amount of hydrogen formed per unit of time can be translated to a relative conversion rate as shown in Figure 5.17 for the BIC iron oxide. The conversion of $\mathrm{Fe}_{3} \mathrm{O}_{4}$ to $\mathrm{Fe}_{2} \mathrm{O}_{3}$ with steam at the applied temperatures is thermodynamically impossible. Therefore the final maximum relative conversion in the oxidation is 0.89 . The limitation of the steam concentration in the gas feed results in a non-differential conditions when the conversion rate is high. This is only the case when BIC iron oxide is used. When the experimental results with the same steam 
conversion (about 30-35\% maximum) are compared and used for the determination of the activation energy a value of $17 \mathrm{~kJ} /$ mole $\mathrm{H}_{2} \mathrm{O}$ for $0.1<\alpha<0.5$ is found, which is very low.

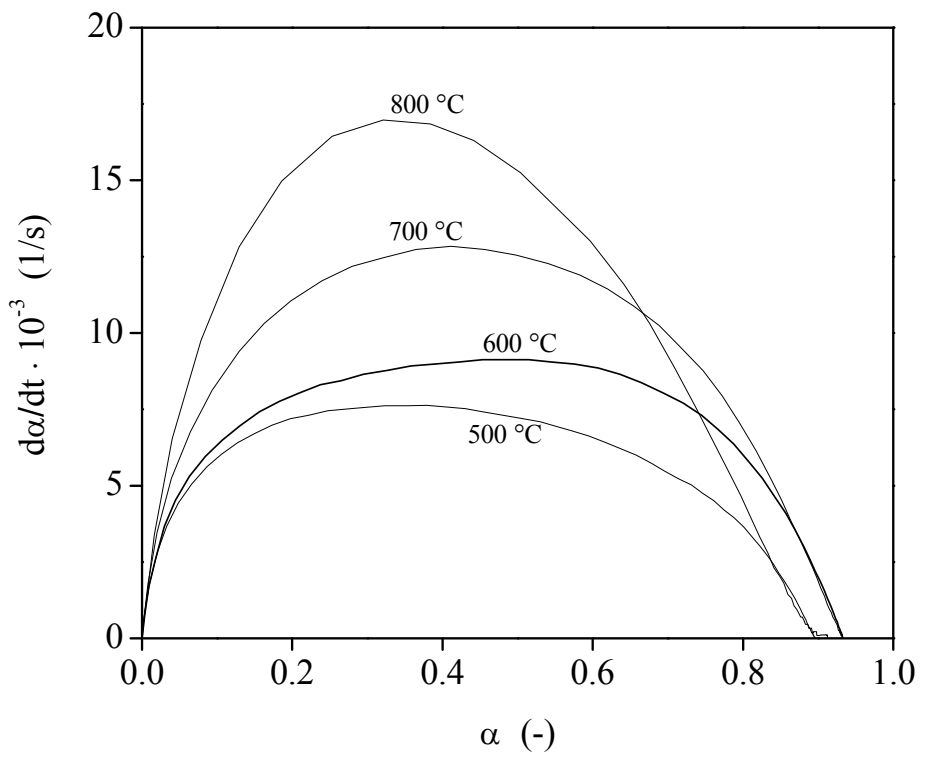

Figure 5.17: Relative conversion rate of the oxidation of BIC iron oxide $\left(d_{p}=125-200 \mu m\right)$.

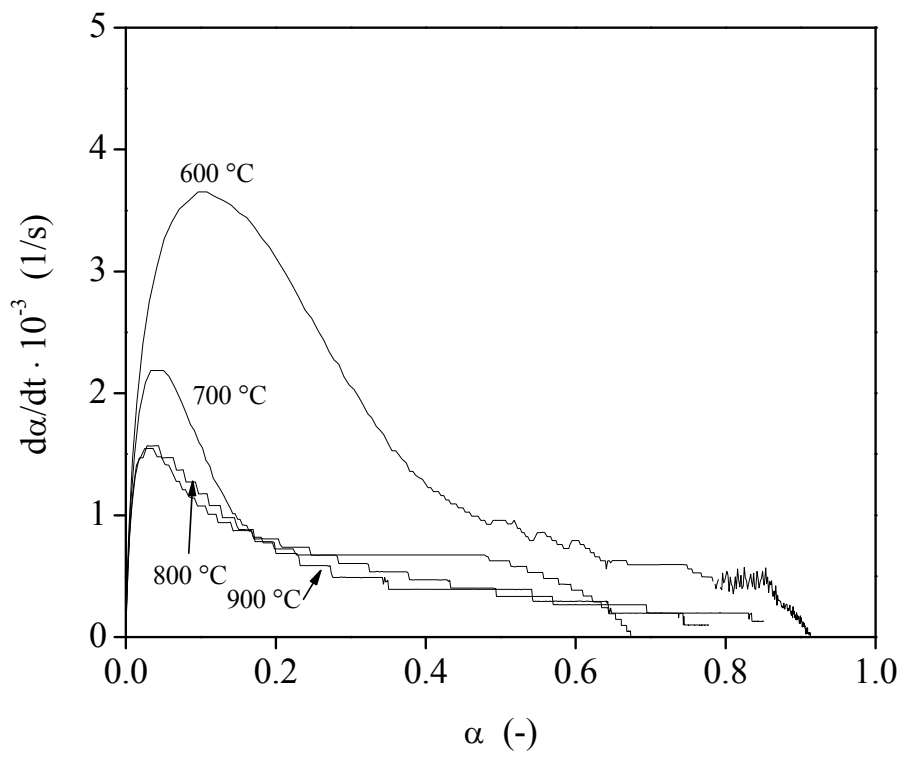

Figure 5.18: Relative conversion rate of the oxidation of $B F$ iron oxide $\left(d_{p}=125-200 \mu m\right)$. 
The oxidation of the BF and pure iron oxide (Figure 5.18 and 5.19) show a much lower oxidation rate under similar conditions compared to the BIC iron oxide. The oxidation rate of the pure iron oxide (Figure 5.19) is extremely slow and a full oxidation of the sample could not be measured. The observed increase in the oxidation rate with decreasing temperature may be explained by the thermodynamics of the system, as the equilibrium constant $\left(\mathrm{K}_{\mathrm{e}}=\mathrm{PH}_{2} \mathrm{O} / \mathrm{PH}_{2}\right)$ decreases with increasing temperature. This effect his however small and cannot explain the observed temperature effect on the oxidation rate with the $\mathrm{BF}$ and pure iron oxide. Another explanation of a decreasing oxidation rate with increasing temperature is sintering, which is likely to take place during the reduction [24]. Reduced iron oxide is expected to have a lower porosity when a higher reduction temperature is applied, which is caused by the enhanced sinter rate at high temperatures. The decrease in porosity will result in a lower oxidation rate.

The additives present in the $\mathrm{BIC}$ and $\mathrm{BF}$ iron oxide are beneficial for the oxidation. In the case of the $\mathrm{BIC}$ iron oxide the $\mathrm{Cr}_{2} \mathrm{O}_{3}$ restricts the temperature induced sintering significantly $[25,26]$. The impurities present in the $\mathrm{BF}$ iron oxide result in a lower reduction rate compared to the pure iron oxide, but improve the oxidation conversion and rate. Apparently the presence of foreign materials, to some extent, helps to maintain structure in the particle and prevents the full blocking of pores upon oxidation.

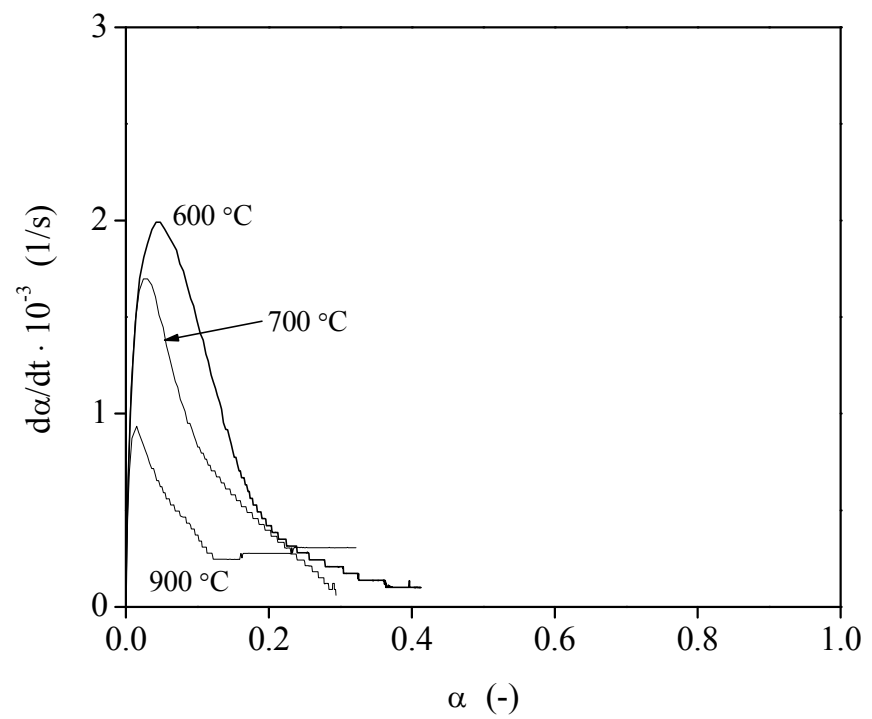

Figure 5.19: Relative conversion rate of the oxidation of pure iron oxide. $\mathrm{H}_{2} \mathrm{O} 10 \mathrm{vol} \%$ in $\mathbf{N}_{2} \cdot d_{p}=125-220 \mu \mathrm{m}$. 
To determine the maximum steam conversion, a large amount of sample material is used (Figure 5.20). The steam conversion with BIC iron oxide in this experiment is close to the equilibrium conversion of steam in the oxidation of iron to wustite, which is maintained up to high conversions of the BIC iron oxide. However with the $\mathrm{BF}$ iron oxide the steam conversion starts at this equilibrium steam conversion but decreases gradually during oxidation. The convex curve of the steam conversion with $\mathrm{BF}$ iron oxide indicates that the gas diffusion dominates the overall oxidation rate. The $\mathrm{BF}$ iron oxide is a non-porous iron oxide and intra particle diffusion of steam to the reaction sites is immediately limited once the particle is partly oxidized.

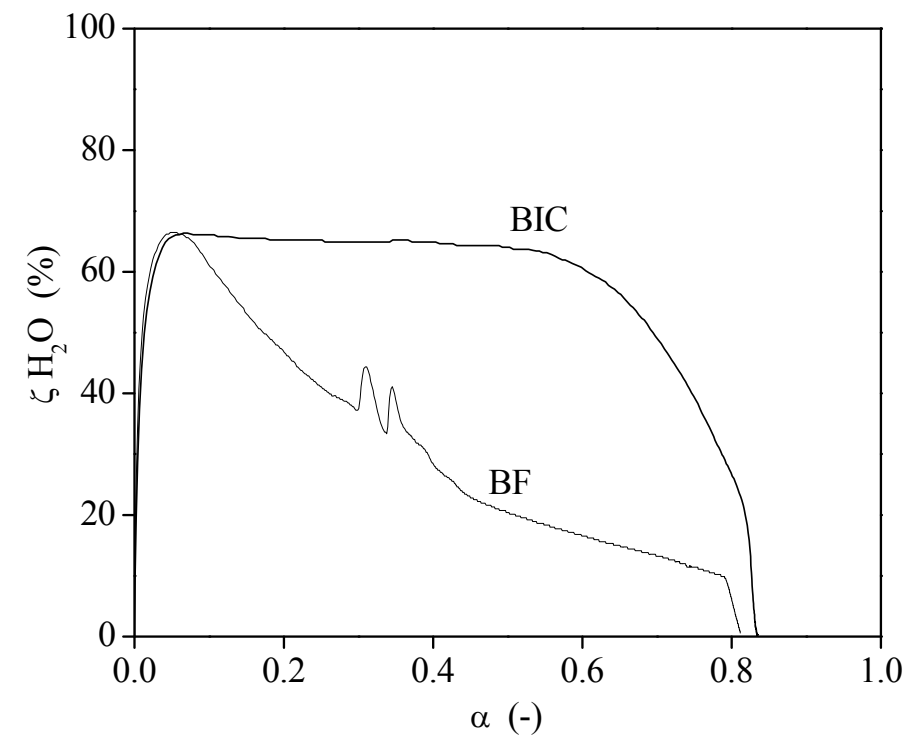

Figure 5.20: Steam conversion during the oxidation of $B I C$ and $B F$ iron oxide. $T=800$ ${ }^{\circ} \mathrm{C}, \mathrm{H}_{2} \mathrm{O} 10$ vol \% in $\mathrm{N}_{2}, d_{\mathrm{p}} 125-200 \mu \mathrm{m}$. Sample amount $200-230 \mathrm{mg}$.

\section{Particle models in the oxidation}

The modelling of the oxidation of the BIC iron oxide is discussed in Chapter 6. In this chapter the GPM is used and adjusted to model the swelling of the grains and the resulting decrease in porosity. This model shows that the oxidation is limited by intra particle diffusion of steam when the porosity decreases. 


\subsection{Discussion}

The reduction and oxidation of iron oxide are complex reactions and the rate of reaction is determined by the chemical reaction itself and different mass transport steps. In kinetic studies it is desired to measure the rate of the chemical reaction only, but it appeared to be very difficult to measure this without any influence of mass transport taking place in and around the iron oxide particle. Although the temperature ramp in the TPR method ensures the reaction to take place at a very low rate (therefore the chemical reaction is most likely the limiting step in the reduction rate), diffusional effects appeared to affect the measured conversion rate.

In a TPR experiment the reduction of hematite to iron took place without the formation of the intermediate wustite, which also explains why a lower activation energy (Friedman method) is found with this technique compared to the isothermal method. For example, for the reduction of pure iron oxide an average $E_{a}$ of $85 \mathrm{~kJ} / \mathrm{mol}$ $(\alpha=0.2-0.5)$ is found from the TPR results (Friedman method) and an average of 59 $\mathrm{kJ} / \mathrm{mol}(\alpha=0.2-0.5)$ from the isothermal reduction results. A lower activation energy can be expected when the reduction takes place with the formation of the intermediate $\mathrm{Fe}_{1-\delta} \mathrm{O}$. The activation energy obtained from the TPR and isothermal experiment at high conversions of the iron oxide $(\alpha>0.6)$ were dubious as the rate of reduction becomes very low for all temperature ramps or temperatures applied.

The main advantage of the TPR method is the fact that the reaction is slowly started during the temperature ramp, which makes the gas analysis more accurate at the onset of the reduction. Furthermore, due to the low conversion rate in a TPR, differential conditions can be easily met. The isothermal method results in a higher conversion rate in both oxidation and reduction compared to the TPR experiment. The benefit of this is that the experiment can be quickly performed. However, a high conversion rate at the onset of the reduction and oxidation makes the gas analysis more difficult and less precise. Also to maintain differential conditions a small sample size is required, especially when high temperatures are applied. The main advantage of the isothermal experiment is that the reduction and oxidation are performed at the expected conditions in the steam-iron process. 


\section{Steam-iron process}

The reduction and oxidation reactions are the basis of the steam-iron process. Understanding the mechanism of the reduction and oxidation is essential to design a steam-iron cycle with iron oxide. In this chapter the results of the reduction and oxidation reaction are obtained with different materials. The BIC iron oxide showed good results in both reduction and oxidation and it appeared that a highly porous material is beneficial in the steam-iron process.

The BF iron oxide, which is a non-porous iron oxide, resulted in low conversion rates compared to the BIC iron oxide in the reduction and oxidation. The slow oxidation, especially when the reaction is near completion $\left(\mathrm{Fe}_{3} \mathrm{O}_{4}\right)$ is limited by diffusion of steam to the reaction sites for $\mathrm{BF}$ and pure iron oxide. This diffusion process is very slow when the porosity of the iron oxide is low, especially when the oxidation is near completion $\left(\mathrm{Fe}_{3} \mathrm{O}_{4}\right)$. The porosity of the particle during reduction is expected to increase due to the removal of oxygen from the lattice structure. However the results showed that the formation of iron and a high temperature in the reduction both resulted in sintering of the material and to a decrease in the porosity of the material. The use of additives (like $\mathrm{Cr}_{2} \mathrm{O}_{3}$ ) in the iron oxide reduces the temperature induced sintering and therefore a higher oxidation rate and a better conversion in the oxidation could be achieved with the BIC iron oxide.

When pyrolysis oil is applied as feedstock in the steam-iron process, iron oxide will probably be cycled between the magnetite and wustite phase (Chapter 4). When iron is not being formed this may ultimately result in less sintering of the iron oxide during reduction, which is beneficial for the reoxidation of the iron oxide.

\subsection{Conclusions}

The TPR method appeared not to be suitable to analyse the reduction of magnetite to iron with the formation of wustite as intermediate. To study the reduction with the formation of wustite, giving insight in the reduction and oxidation reaction at the reaction conditions applied in the steam-iron process an isothermal method was applied. Three different iron oxides, different in composition and porosity were tested in both methods and results showed that a high porosity of the iron oxide benefits both reduction and oxidation rate. Sintering of the iron oxide during reduction took place especially at high reduction temperatures $\left(>600^{\circ} \mathrm{C}\right)$ and/or high conversion of the 
iron oxide, indicating that the formation of iron enhances temperature induced sintering. The porosity of the iron formed in the reduction is increased with an increased impurity concentration in the iron oxide and/or an increased vacancy concentration in the wustite phase. A low porosity after reduction led to a low oxidation rate in the subsequent oxidation. The oxidation rate decreases with progressive conversion during oxidation and a full oxidation to magnetite is slow or could not be measured. The BIC iron oxide was the only iron oxide resulting in high reduction and oxidation rates, caused by the initial high porosity and the presence of foreign materials like $\mathrm{Cr}_{2} \mathrm{O}_{3}$, which prevented temperature induced sintering during reduction. The presence of $\mathrm{SiO}_{2}$ in the used blast furnace iron oxide resulted in a low reduction rate.

\subsection{Nomenclature}

\begin{tabular}{|lll|}
\hline$\alpha$ & $(-)$ & Relative conversion of the iron oxide \\
$\alpha_{\mathrm{g}}$ & $(-)$ & Relative conversion of a single grain \\
$\mathrm{A}$ & $\left(\mathrm{m}^{2}\right)$ & Surface area \\
$\mathrm{A}_{0}$ & $\left(\mathrm{~m}^{2}\right)$ & Initial surface area at the start of the oxidation \\
$\mathrm{C}_{\mathrm{H} 2 \mathrm{O}, 0}$ & $\left(\mathrm{~mol}^{3}\right)$ & Steam concentration in the bulk \\
$\mathrm{D}_{\text {grain }}$ & $\left(\mathrm{m}^{2} / \mathrm{s}\right)$ & Overall diffusion coefficient in a grain \\
$\mathrm{D}_{\mathrm{R}}$ & $\left(\mathrm{m}^{2} / \mathrm{s}\right)$ & Diffusivity of gas in between the grains \\
$\mathrm{D}_{\mathrm{R} 0}$ & $\left(\mathrm{~m}^{2} / \mathrm{s}\right)$ & Initial diffusivity of gas in between the grains in the first oxidation \\
& & reaction cycle \\
$\mathrm{D}_{\mathrm{H}_{2} \mathrm{O}_{-} \mathrm{N}_{2}}$ & $(\mathrm{~m} / \mathrm{s})$ & Molecular gas diffusion \\
$\varepsilon$ & $(-)$ & \\
$\varepsilon_{0}$ & $(-)$ & Voidage fraction during oxidation \\
$\mathrm{f}_{\mathrm{S}}$ & $(-)$ & Initial voidage fraction at the start of the oxidation \\
$\mathrm{f}_{\mathrm{S} 0}$ & $(-)$ & Solid fraction \\
$\mathrm{k}_{\mathrm{s}}$ & $(\mathrm{m} / \mathrm{s})$ & Initial solid fraction \\
$\mathrm{k}_{\mathrm{v}}$ & $(\mathrm{m} / \mathrm{s})$ & Surface reaction rate constant \\
$\mathrm{k}_{\mathrm{g}}$ & $(\mathrm{m} / \mathrm{s})$ & Volumetric reaction rate constant \\
$\mathrm{O}$ & $(\mathrm{mole})$ & Mass transfer coefficient \\
$\mathrm{P}$ & $(\mathrm{Pa})$ & Amount of oxygen atoms \\
$\rho$ & $\left(\mathrm{kg} / \mathrm{m}^{3}\right)$ & Pressure \\
$\rho_{0}$ & $\left(\mathrm{~kg} / \mathrm{m}^{3}\right)$ & Density \\
$\mathrm{R}_{\mathrm{p}}$ & $(\mathrm{m})$ & Initial density \\
$\mathrm{R}$ & $(\mathrm{m})$ & Radius of the particle \\
$\mathrm{R}_{\mathrm{i}}$ & $(\mathrm{m})$ & Radial location in the particle \\
$\mathrm{R}_{0}$ & $(\mathrm{~m})$ & Radius of the unreacted particle \\
$\mathrm{R}_{\mathrm{g}}$ & $(\mathrm{J} / \mathrm{molK})$ & Initial particle radius \\
$\mathrm{r}_{\mathrm{g}}$ & $(\mathrm{m})$ & Universal gas constant $(8.31)$ \\
$\mathrm{r}_{\mathrm{gi}}$ & $(\mathrm{m})$ & Grain radius \\
$\mathrm{r}_{\mathrm{g} 0}$ & $(\mathrm{~m})$ & Radius of the unreacted grain \\
$\mathrm{S}_{0}$ & $(\mathrm{~mol})$ & Initial grain radius \\
& & Amount of reactive oxygen atoms in the sample \\
& & \\
& & \\
& &
\end{tabular}




\begin{tabular}{|lll|}
\hline $\mathrm{T}$ & $(\mathrm{K})$ & Temperature \\
$\mathrm{t}$ & $(\mathrm{s})$ & Time \\
$\tau$ & $(-)$ & Time to obtain full conversion of the sample \\
$\varphi$ & $\left(\mathrm{m}^{3} / \mathrm{s}\right)$ & Total gas flow \\
$\varphi_{\mathrm{H} 2, \text { in }}$ & $\left(\mathrm{m}^{3} / \mathrm{s}\right)$ & Flow of hydrogen to the reactor \\
$\varphi_{\mathrm{H} 2, \text { zero }}$ & $\left(\mathrm{m}^{3} / \mathrm{s}\right)$ & Decrease in hydrogen flow obtained from the "zero" experiment \\
$\varphi_{\mathrm{N} 2}$ & $\left(\mathrm{~m}^{3} / \mathrm{s}\right)$ & Flow of nitrogen to the reactor \\
\hline
\end{tabular}

\subsection{Literature}

1 L. von Bogdandy, H.-J. Engell, The Reduction of Iron Ores: Scientific Basis and Technology, Springer-Verlag, Berlin, 1971.

2 J. Szekely, J.W. Evans, H.Y. Sohn, Gas-Solid Reactions, Academic Press Inc, New York, 1976.

3 Ullmann's Encyclopedia of Industrial Chemistry, 7th ed., John Wiley \& Sons, 2006.

4 Piotrowski, K., et al., Int. J. of Hydrogen Energy, 2005.

5 Tokuda, M., H. Yoshikoshi, and M. Ohtani, ISIJ Int., 13 (1973) p. 350-362.

6 Edstrom, J.O. and G. Bitsanies, J. of Metals, (1955) p. 760-765.

7 Slattery, J., et al., Ind.\& Eng. Chem. Res., 34 (1995) p. 3405-3410.

8 Tiernan, M.J., P.A. Barnes, G.M.B. Parkes, J. of Phys. Chem. B, 105 (2001) p. 220-228.

9 Pineau, A., N. Kanari, and I. Gaballah, Thermochimica Acta, 447 (2006) p. 89-100.

10 Sastri, M.V.C., R.P. Viswanath, and B. Viswanathan, Int. J. of Hydrogen Energy, 7 (1982) p. 951-955.

11 Shimokawabe, M., Thermochimica Acta, 28 (1979) p. 287.

12 Lin, H.-Y., Y.-W. Chen, and C. Li, Thermochimica Acta, 400 (200) p. 61-67.

13 Wimmers, O.J., P. Arnoldy, and J.A. Moulijn, J. of Phys. Chem., 90 (1986) p. 1331-1337.

14 McKewan, M.C., Trans. of the Metall. Soc. of AIME, 218 (1960) p. 2-6.

15 Kanervo, J.M., Kinetic analysis of temperature-programmed reactions in Chemical Technology, Helsinki University, Espoo, 2003.

16 Munteanu, G. and M. Craiu, Catalysis Letters, 50 (1993) p. 49-54.

17 Galvita, V. and K. Sundmacher, J. of Mat. Science, 42 (2007) 9300-9307.

18 Munteanu, G. and P. Budrugeac, J. of Mat. Science, 38 (2003) 1995-2000.

19 McKewan, M.C., Trans. of the Metall. Soc. of AIME, 221 (1961) p. 140-145. 
20 Monti, T. and A. Baiker, J. of Catalysis,. 83 (1983) p. 323-325.

21 Malet, P. and A. Caballero, J. of Chem. Soc., Faraday Trans. I, 84 (1988) p. 2369-2375.

22 Carneiro de Araújo, G. and M. do Carmo Rangel, Catalysis Today, 62 (2000) p. 201-207.

23 Bonalde, A., A. Henrique, and M. Manrique. ISIJ Int., 45 (2005) p. 12551260.

24 Edmistion, W.A. and R.E. Grace, Trans. of the Metall. Soc. of AIME, 236 (1966) p. 1547.

25 Rhodes, C. and G.J. Hutchings, PCCP, 5 (2003) p. 2719-2723.

26 Lei, Y., N.W. Cant, and D.L. Trimm, J. of Catalysis, 239 (2006) p. 227-236. 


\title{
Chapter 6
}

\section{Deactivation of iron oxide used in the steam-iron process}

\begin{abstract}
In the steam-iron process pure hydrogen can be produced from any hydrocarbon feedstock by using a redox cycle of iron oxide. One of the main problems connected to the use of the iron oxide are the inherent structural changes that take place during oxygen loading and unloading leading to severe deactivation. This deactivation reduces the capability of the material for uptake and release of oxygen, basically due to loss of specific surface area. In this chpater a simplified (reactive) sintering model is used to derive a relation for the loss in surface area of the material in the first redox cycles. This model is based on the relative conversion and the resulting swelling of the material during oxidation. Furthermore the grainy pellet model is used to describe the increase in grain size and increase in solid fraction in a particle due to the subsequent cycling of the iron oxide in the redox process. Model predictions are compared with redox experiments of $\mathrm{H}_{2} / \mathrm{H}_{2} \mathrm{O}-\mathrm{Fe} / \mathrm{Fe}_{3} \mathrm{O}_{4}$ at $800{ }^{\circ} \mathrm{C}$. Grain growth over subsequent cycles could explain the observed deactivation over about 20 cycles satisfactorily.
\end{abstract}




\subsection{Introduction}

The steam-iron process is based on the redox cycle of iron oxides, in which the reduction of the iron oxide can be performed with any hydrocarbon feedstock. In the oxidation the reduced iron oxide is oxidized with steam in a separate step, resulting in the production of pure hydrogen. The process can be operated oncethrough and in cyclic mode. Iron oxide has been used in the process, as it is a cheap and abundant material. A reduced life time due to structural changes in the material is therefore not necessarily prohibitive. In the ultimate case iron ore, normally used as a feedstock in the blast furnace process, can be used.

It was observed that the reaction rate in both reduction and oxidation decreased over subsequent cycles, which was mainly attributed to sintering of the iron oxide. It is important to understand the observed deactivation, as the knowledge thus obtained will support the development of fabrication methods to enhance the life time of the material. Several researchers [1-4] investigated the underlying mechanisms of deactivation. In these studies the deactivation was attributed to sintering due the high temperatures applied in the process, resulting in a loss of surface area.

In this chapter the deactivation will also be attributed to sintering of the material. The enhanced sintering and reduction of surface area however are believed to be mostly due to the release and uptake of oxygen resulting into subsequent shrinking and swelling of the material. A new sintering model for reactive systems is introduced. The grainy pellet particle model is extended with a mechanism to describe the observed deactivation. Predictions of these models are compared with experimental data on the effect of repetitive cycling on the relative conversion rate (deactivation) of the particles during oxidation.

In this chapter the reduction is performed with a $\mathrm{H}_{2} / \mathrm{H}_{2} \mathrm{O}$ mixture only. In this way the reaction system is simplified. This enables the study of the effect of the iron oxide deactivation on the reduction and oxidation rate in the process in detail.

The iron oxide in a pure hydrogen environment will be reduced to metallic iron. Increasing the water content in the gas phase, or decreasing the $\mathrm{H}_{2} /\left(\mathrm{H}_{2}+\mathrm{H}_{2} \mathrm{O}\right)$ ratio, will result in a lower relative conversion of the iron oxide (Chapter 2, Figure 2.10). The reaction mechanism of the reduction and oxidation is discussed in more detail in Chapter 5. 


\subsection{Model to describe the structural changes}

For the present analysis structural changes are most easily understood by considering the steam oxidation. First an estimate is given for the surface reduction due to the swelling of the particles as a result of the uptake of oxygen. If we start from a material that is reduced into partly metallic iron and partly the wustite phase, and assume that these phases occur in spherical geometry as described by the grainy pellet model [5], we will see that upon oxidation the grains will swell (Figure 6.1) and will merge (Figure 6.2) at places where they are touching each other. The model described in this paragraph will focus on the structural changes locally in the particle.

particle

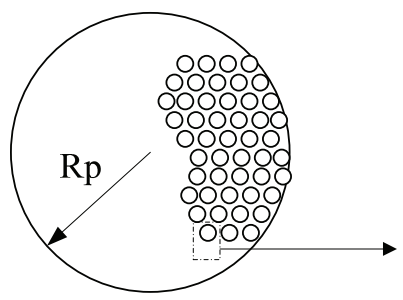

before reaction

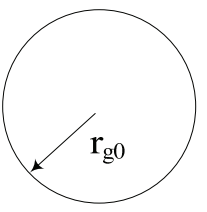

grain

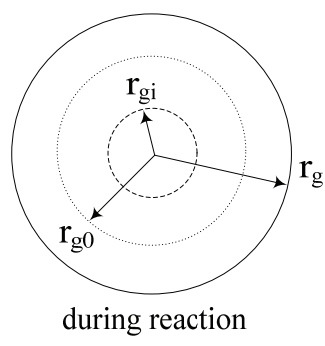

during reaction

Figure 6.1: Overview of a particle consisting of grains, which swell during the oxidation reaction.

In a previous analysis, to describe the merging of spherical particles which are part of a random stacking [6], a z-parameter has been introduced to indicate reduction of the center-to-center distance of initially touching grains (Figure 6.2).

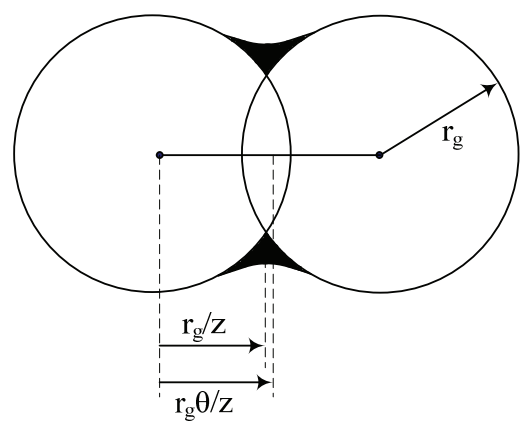

Figure 6.2: Neck growth and approach of two spherical particles. 
This parameter directly relates to the density changes of the structure, either by sintering as it was the case in [6] or the swelling due to uptake of oxygen in the case of steam oxidation by:

$$
z=\frac{r_{g}}{r_{g 0}}=\left(\frac{\rho}{\rho_{0}}\right)^{1 / 3}
$$

Where $\rho_{0}$ is the initial stacking density, which is a value corresponding to a random packing, and $\rho$ is the actual stacking density. Obviously $z=1$ is the starting value. In the case of temperature driven sintering the $\mathrm{z}$ parameter indicates the extent to which the center-to-center distance reduces and in the present case of combined merging and swelling it indicates the overall change of center-to-center distance from the starting value of $r_{\mathrm{g} 0}$ (=initial grain size).

The initial radius of a grain in a stacking is equal to $r_{g}$, it swells during oxidation to rg while leaving a spherical inner core of radius $r_{g i}$, unreacted. We use a similar argument and set [7]:

$$
\mathrm{r}_{\mathrm{g}}^{3}=\mathrm{Z}_{\mathrm{v}} \mathrm{r}_{\mathrm{g} 0}{ }^{3}+\left(1-\mathrm{Z}_{\mathrm{v}}\right) \mathrm{r}_{\mathrm{gi}}{ }^{3}
$$

Where $Z_{v}$ is the specific swelling, based on the ratio of the molar volumes of the reactants and products, during the phase change [5] and is a characteristic number for the transition of metallic iron to wustite: 2.1, and for wustite to magnetite: 1.3. Equation 6.2 should be considered approximate as individual swelling particles have also swelling neighbors, on the average about 7.3 [8] in a random stacking, which prohibits material deposition in the zones where they meet each other. Therefore the more the particles swell the faster the radii increase. The deviation from equation 6.2 is determined by the ratio between free surface and the neck area.

Now with the relative conversion of a single grain:

$$
\alpha_{\mathrm{g}}=1-\frac{\mathrm{r}_{\mathrm{gi}}{ }^{3}}{\mathrm{r}_{\mathrm{g} 0}{ }^{3}}
$$


we arrive at a relation between density change, reaction progress and $Z_{\mathrm{v}}$ :

$1+\alpha_{\mathrm{g}}\left(\mathrm{Z}_{\mathrm{V}}-1\right)=\frac{\rho}{\rho_{0}}$

Of more interest is the related reduction in specific area as this is determining to a large extent the loss of reactivity during progressive cycling between reduction and oxidation. By the same reasoning as before we can find an approximate expression for the loss of internal surface area. Starting from equation 6.4 following the analysis in [6] we find that:

$$
\mathrm{z}^{3}=\frac{\mathrm{r}_{\mathrm{g}}{ }^{3}}{\mathrm{r}_{\mathrm{g} 0}{ }^{3}}=\frac{\rho}{\rho_{0}}=Z_{\mathrm{v}}+\left(1-\mathrm{Z}_{\mathrm{v}}\right)\left(1-\alpha_{\mathrm{g}}\right)
$$

The reduction in the free surface area per grain is given by [6]:

$$
\Delta \mathrm{A}\left(\mathrm{r}_{g}, \mathrm{G}_{0}, \mathrm{z}, \mathrm{C}\right)=\int \pi \mathrm{r}_{\mathrm{g}}{ }^{2}\left(1-\frac{\theta^{2}}{\mathrm{z}^{2}}\right) \partial_{\theta} \mathrm{G}(\theta) \mathrm{d} \theta=\mathrm{G}_{0} \pi \mathrm{r}_{\mathrm{g}}{ }^{2}\left(1-\frac{1}{\mathrm{z}^{2}}\right)+\mathrm{C} \pi \mathrm{r}_{\mathrm{g}}{ }^{2}\left(\frac{2}{3} \mathrm{z}-1+\frac{1}{3 \mathrm{z}^{2}}\right)
$$

Taking into account that the second term only results in a minor non-linear contribution and the fact that material carried away from the place of merging of the particles is deposited in the outer circumference of the neck $\left(z^{-2}\right.$ is replaced by $(2 z-1)^{-}$ ${ }^{2}$ ), this equation can be simplified to:

$$
\Delta \mathrm{A}=-\pi \mathrm{r}_{\mathrm{g}}^{2} \mathrm{G}_{0}\left(1-\frac{1}{(2 \mathrm{z}-1)^{2}}\right)
$$

We set $\mathrm{z}=1+\delta \mathrm{z}$ and take into account only first order terms in $\delta \mathrm{z}$ and take the value of 7.3 as the number of contact points with adjacent particles $\left(\mathrm{G}_{0}\right)$ : 


$$
\frac{\Delta \mathrm{A}}{\mathrm{A}}=-\frac{1}{3} \mathrm{G}_{0} \alpha\left(\mathrm{Z}_{\mathrm{v}}-1\right)=-2.4 \alpha\left(\mathrm{Z}_{\mathrm{v}}-1\right)
$$

In equation $6.8, \alpha$ is not the relative conversion of a single grain, but is the average local relative conversion in a particle. Actually we should also take into account that by the swelling new contacts are created which accelerate the reduction in free area. This effect has been quantified in [6] and is represented with the $\mathrm{C}$ factor in equation 6.6. It was found that it gives rise to second order contributions in the densification parameter $\delta z$ which will not be taken into account in the present analysis as it introduces a new, and for the time being, unknown parameter. In any case it should be remembered that this simplification makes the analysis most accurate at the onset of the swelling (low $\alpha$ ), it neglects the creation of new contacts and increase of surface area in the non neck zone of the grains (high $\alpha$ ). Also in the mathematical procedure the dependence on $\delta z$ is consistently kept first order to keep the analysis simple.

This simple model tells us that particularly at the beginning of the cycling already at low relative conversions $(\alpha=0.1)$ and $Z_{\mathrm{v}}=2.1$ (in the oxidation of pure $\mathrm{Fe}$ to $\mathrm{Fe}_{3} \mathrm{O}_{4}$ ), a surface area reduction of more than $26 \%$ can be expected.

The models derived above are based on first order geometrical arguments and the fact that diffusion of iron and/or oxygen ions through the layers formed during both reduction and oxidation are responsible for the in-grain transport. Clearly the ion that diffuses and its related diffusion coefficient, is dependent on the kind of layer being formed, which is also different for the oxidation and reduction and depends on the internal transport mechanism as well as electric compensation currents.

The driving force for densification is the free energy reduction by material moving into the neck zone of the grains. The various mechanisms for internal material transport, like bulk diffusion, surface diffusion or even plastic flow are responsible for initially the filling up of the neck zones and ultimately complete densification up to a maximal theoretical value. In the case of iron oxide the redox reactions stimulate the internal mobility of ions so that the effect is much stronger than in the case of free sintering. The result is that sintering in the redox cycle occurs at far lower temperatures than for instance in normal ceramics like Alumina or Zirconia. Nevertheless the model developed in the nineties of the last century $[6,9]$ can be used to interpret the observations in the chemical looping of iron oxide. 
The ultimate effect is that a fine grained structure contracts into a new structure of densely packed grains with reduced access of gas to the internal areas but with new channels to better feed the larger particles with the reduction and oxidizing gasses. The simplified equation 6.8 does not take into account the local opening up and densification of the structure, resulting in a distribution of the coordination number in the particle. It assumes that the coordination number is equal to 7.3, which may be true for the first redox cycles and/or low relative conversions of the iron oxide. However when the cycle number increases and a high relative conversion of the iron oxide is used these effects should be taken into account.

The analysis in [9] is followed and the local densification and opening up of the structure can be described as follows:

$$
\frac{\mathrm{d}(\mathrm{z}-\overline{\mathrm{z}})}{\mathrm{dt}}=\frac{2 \gamma}{3 \mathrm{r}_{g} \mathrm{Gz}^{2} \eta}[\overline{\mathrm{G}}(\mathrm{z}-\overline{\mathrm{z}})+\delta \mathrm{z}(\mathrm{G}-\overline{\mathrm{G}})]
$$

The second term on the right shows that, if there is some densification (given by $\delta z)$, resulting in a higher coordination than average $(G-\bar{G}>0)$, it will increase the local densification $(\mathrm{d}(\mathrm{z}-\overline{\mathrm{z}}) / \mathrm{dt}>0)$. When locally the coordination number is increasing due to densification, this densification will be enhanced by the first term on the right hand side $((\mathrm{z}-\overline{\mathrm{z}})>0)$. This equation applies to both densification and opening up of the structure as dictated by the variation in initial coordination of the structure. Unfortunately, like also in the case of ceramic materials, the temperature dependent factors describing the internal transport mechanism ( $\eta$ ), and surface energy and $(\gamma)$ cannot be quantitatively determined from the basic materials properties [9]. It therefore makes no sense to quantify these parameters, but to adopt a global parameter which could be related to observed rates of surface area reduction. If we translate this formula to the current system, we can at least directly identify the $\delta z$ with the $\alpha$ value as it follows from equation 6.5 .

$$
\mathrm{z}=1+\delta \mathrm{z} \quad \text { so that } \delta \mathrm{z}=\frac{\alpha\left(\mathrm{Z}_{\mathrm{v}}-1\right)}{3}
$$


Each reduction-oxidation cycle sees the $\delta z$ decrease and increase, but the sintering due to filling up of the inter-grain area is irreversible. Therefore for a complete redox cycle, in areas with high coordination or density an increased densification or reduction in surface area is occurring. From equation 6.10 it can be seen that with a higher relative conversion in the redox cycle the higher this effect will be. It should be remembered that the value of $Z_{v}$ will increase with increasing conversion, especially when all the magnetite has reacted to wustite and formation of Fe takes place $(\alpha>0.25)$.

\subsection{Experimental}

The experiments performed in this chapter are similar to the isothermal reduction and oxidation experiments in Chapter 5. A catalytic iron oxide made by the Boreskov Institute of Catalysis (BIC, Novosibirsk, Russia) is used in all experiments. The composition of this BIC iron oxide is shown in Table 5.3 and the particles size used in all experiments is in the range of $0.125-0.2 \mathrm{~mm}$.

\subsection{Results}

\subsubsection{Redox cycles}

Redox cycles are performed under three different gas atmospheres in the reduction. In all cases, the reaction temperature was $800+/-4{ }^{\circ} \mathrm{C}$ and the pressure 1 bar. It is expected that using a $\mathrm{H}_{2} / \mathrm{H}_{2} \mathrm{O}$ mixture in the reduction will result in a lower relative reduction of the iron oxide material due to thermodynamic limitations. In Figure 6.3A, B and $\mathrm{C}$ the relative conversion rate and the relative conversion during (re-)oxidation of the material is shown and it shows that the more water is present in the reduction mixture the lower the relative conversion obtained in the cycle. 

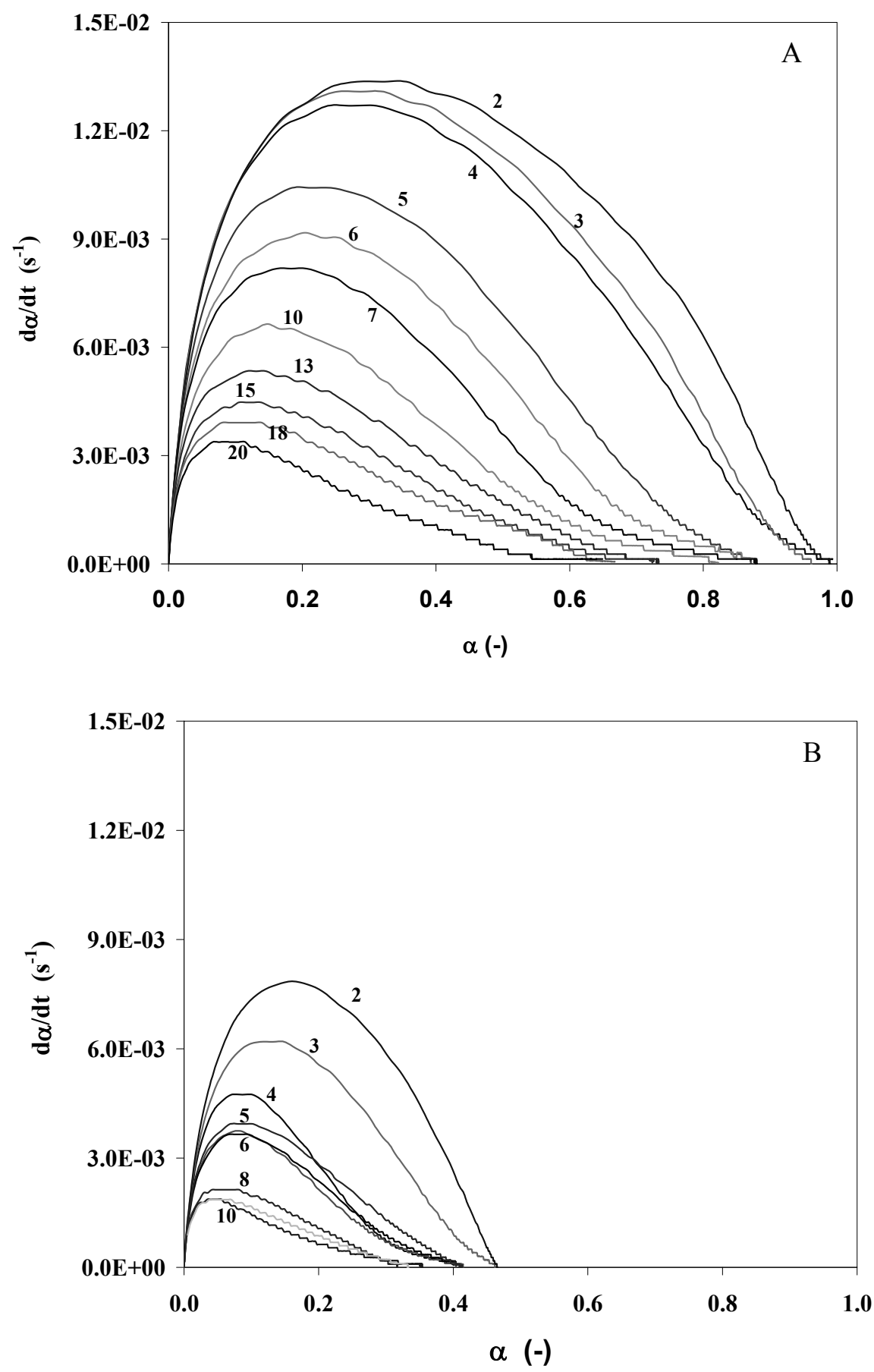


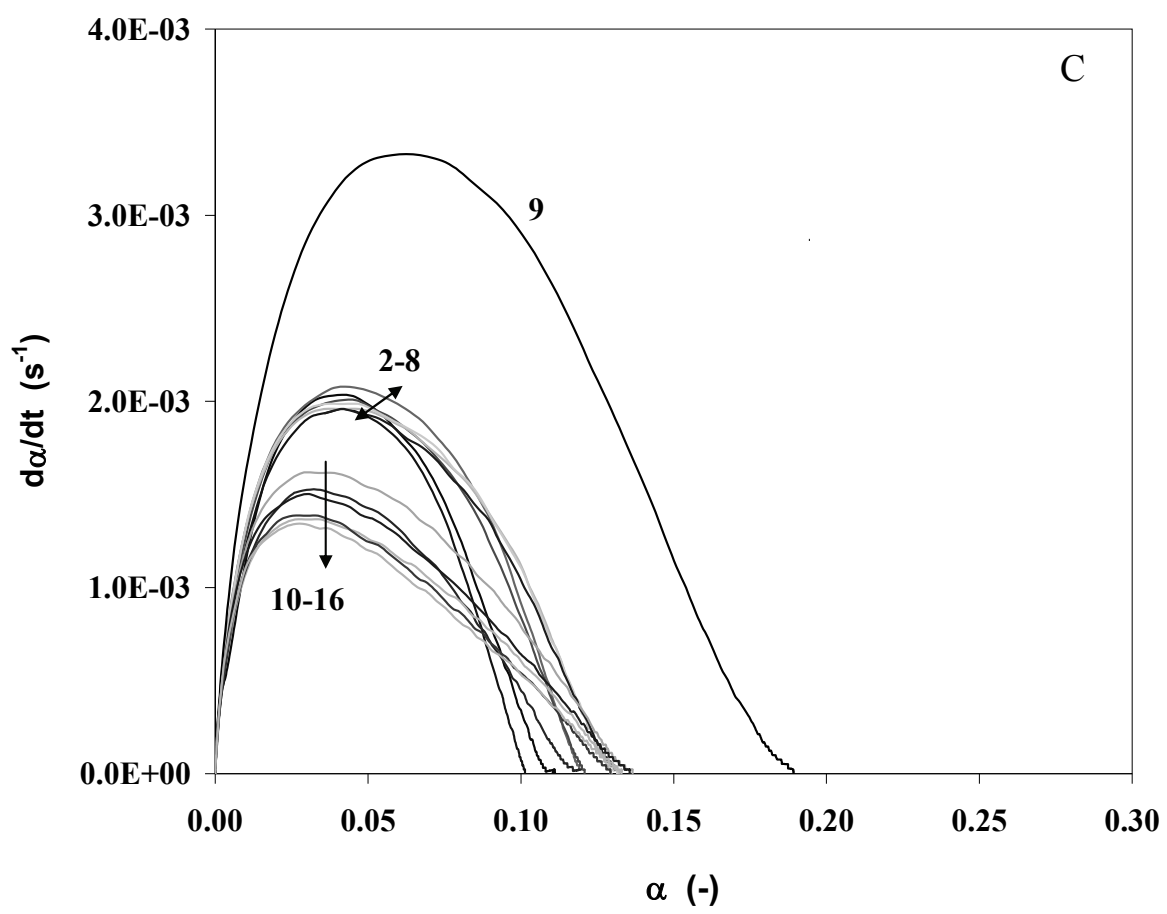

Figure 6.3: The reaction rate of the oxidation of BIC iron oxide over subsequent cycles (cycle numbers are indicated in the figure):

A/ Reduction 30 vol \% $\mathrm{H}_{2}$, oxidation 10 vol $\% \mathrm{H}_{2} \mathrm{O}$.

B/ Reduction 30 vol \% $\mathrm{H}_{2}, 10$ vol\% $\mathrm{H}_{2} \mathrm{O}$, oxidation 10 vol $\% \mathrm{H}_{2} \mathrm{O}$.

C/ Reduction 30 vol \% $\mathrm{H}_{2}, 20$ vol\% $\mathrm{H}_{2} \mathrm{O}$, oxidation 10 vol $\% \mathrm{H}_{2} \mathrm{O}$.

The curve shape in Figure 6.3 shows an initial increase in the relative conversion rate at low alpha's. This is caused by the experimental procedure and mainly due to the response time of the analyzer. Therefore the increase in the relative conversion rate at the onset of the reaction is purely an experimental artifact. It is expected that the relative conversion rate is constant or (slowly) decreasing at low alpha's.

The steam in the reduction gas mixture restricts the relative conversion in the reduction, which can be expected on the basis of thermodynamics, however not to the extent observed. A $30 \mathrm{vol} \% \mathrm{H}_{2} / 10$ vol\% $\mathrm{H}_{2} \mathrm{O}$ mixture can result in a reduction to metallic iron and the $30 \mathrm{vol} \% \mathrm{H}_{2} / 20 \mathrm{vol} \% \mathrm{H}_{2} \mathrm{O}$ mixture only in a reduction to wustite. The expected conversion, based on thermodynamics is not obtained. Apparently the decrease in relative conversion due to the presence of steam is also restricted 
kinetically. The reduction degree shows a linearly dependence on the $\mathrm{H}_{2} \mathrm{O}$ content in the hydrogen mixture (Figure 6.4).

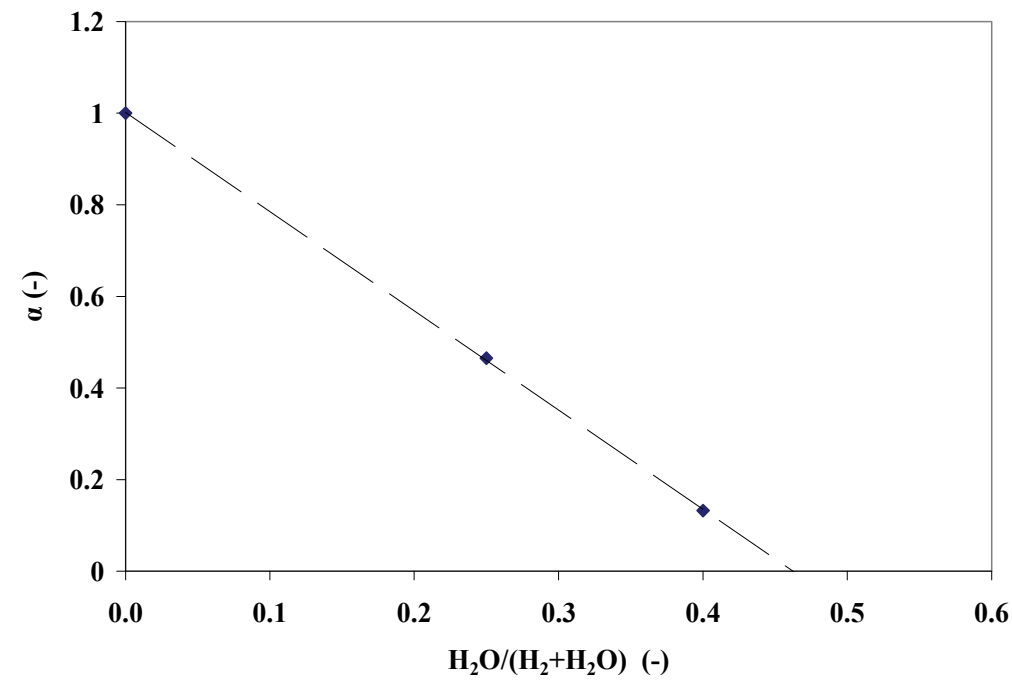

Figure 6.4: The effect of the $\mathrm{H}_{2} \mathrm{O}$ concentration on the iron oxide conversion in the reduction with a $\mathrm{H}_{2} / \mathrm{H}_{2} \mathrm{O} / \mathrm{N}_{2}$ mixture. The $\mathrm{H}_{2}$ concentration is constant and 30 vol \% in the gas mixture.

From Figure 6.3 maximum values of $\mathrm{d} \alpha / \mathrm{dt}$ are derived as a function of the cycle number for the oxidation. These maxima are plotted in figure 6.5. Due to limits of the experimental system it is not sure if the measured max. $d \alpha / d t$ is the true maximum. However, the measured max. $\mathrm{d} \alpha / \mathrm{dt}$ is sound enough for trend detection as function of the cycle number. Same can be done for the reduction. The analysis of the deactivation will be based on the oxidation behavior as the oxidation is performed under similar conditions for all experiments. Furthermore the addition of steam in the reduction gas results in a less stable hydrogen measurement and therefore this data shows more scatter. The results of the maximum $\mathrm{d} \alpha / \mathrm{dt}$ for the oxidation are shown in Figure 6.5A, B and C. 

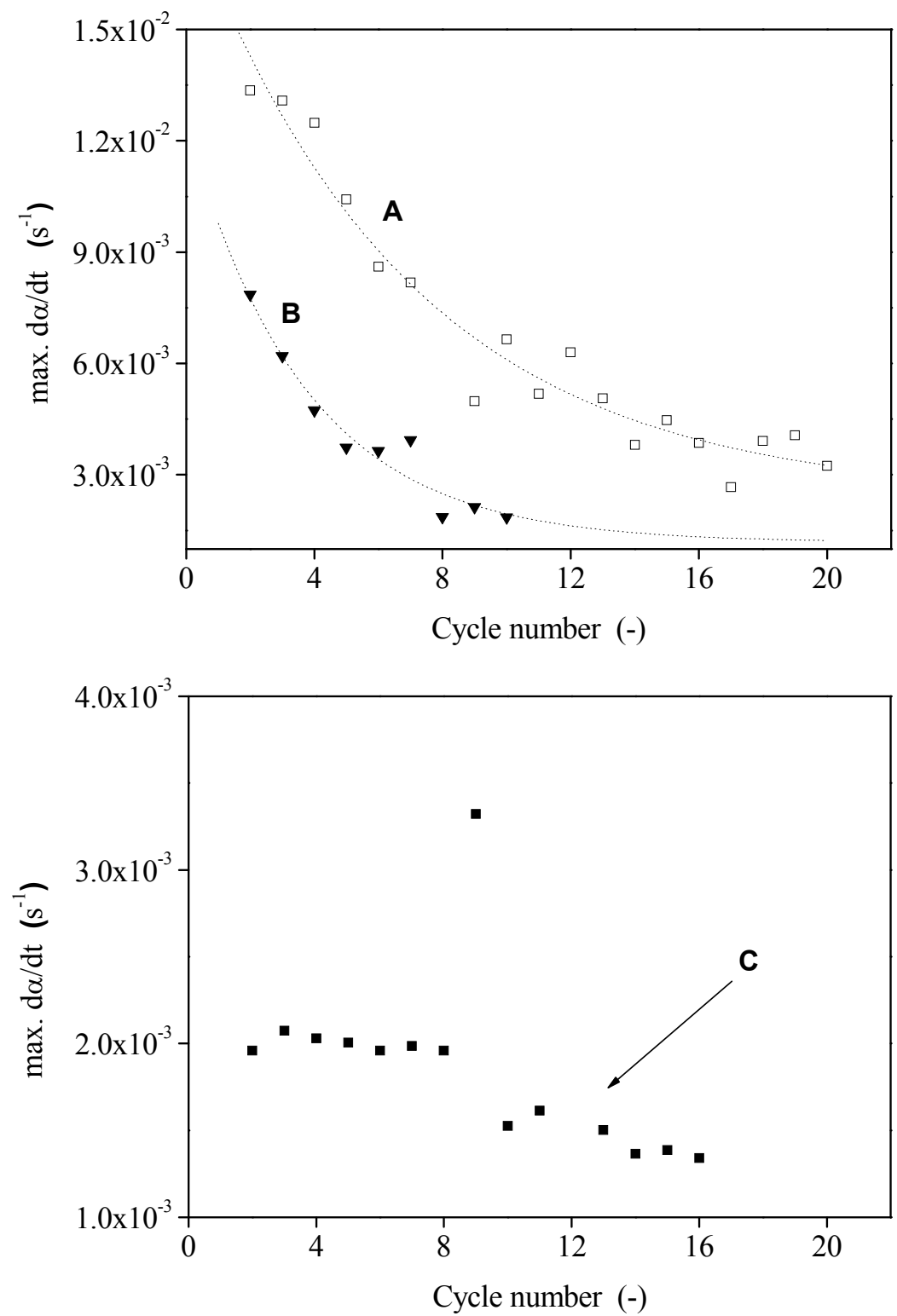

Figure 6.5: The maximum reaction rate of the oxidation of BIC iron oxide over subsequent cycles :

A/ Reduction 30 vol \% $\mathrm{H}_{2}$, oxidation 10 vol \% $\mathrm{H}_{2} \mathrm{O}$.

B/ Reduction 30 vol \% $\mathrm{H}_{2}, 10$ vol\% $\mathrm{H}_{2} \mathrm{O}$, oxidation 10 vol $\% \mathrm{H}_{2} \mathrm{O}$.

C/ Reduction 30 vol \% $\mathrm{H}_{2}, 20$ vol\% $\mathrm{H}_{2} \mathrm{O}$, oxidation 10 vol $\% \mathrm{H}_{2} \mathrm{O}$.

It can clearly be seen that there is a continuous reduction in the maximum rate $\mathrm{d} \alpha / \mathrm{dt}$. This latter is due to progressive reduction in surface area of the particle when 
the grains are merging. In section 6.4.4 the decrease in surface area, caused by the merging of grains, will be used to study the relative conversion rate of a particle in the oxidation over subsequent cycles.

The measured decrease in the apparent final relative conversion in the material as a function of the cycle number (Figure 6.3A and B, A: cycle $2 \rightarrow \alpha=1$, cycle $20 \rightarrow$ $\alpha=0.65$ ) is caused by the limitation in the measurable reaction rate. The minimum measurable hydrogen concentration difference that can be measured is $0.03 \mathrm{vol} \% \mathrm{H}_{2}$, which would result in a minimum measurable relative conversion rate of $3.5 \cdot 10^{-4} \mathrm{~s}^{-1}$ (when $9.6 \mathrm{mg}$ of sample is used). To measure the relative conversion rate when the sample is near complete conversion a sample of $204 \mathrm{mg}$ is used and in this case no decrease in the relative conversion is measured over subsequent cycles (Figure 6.6).

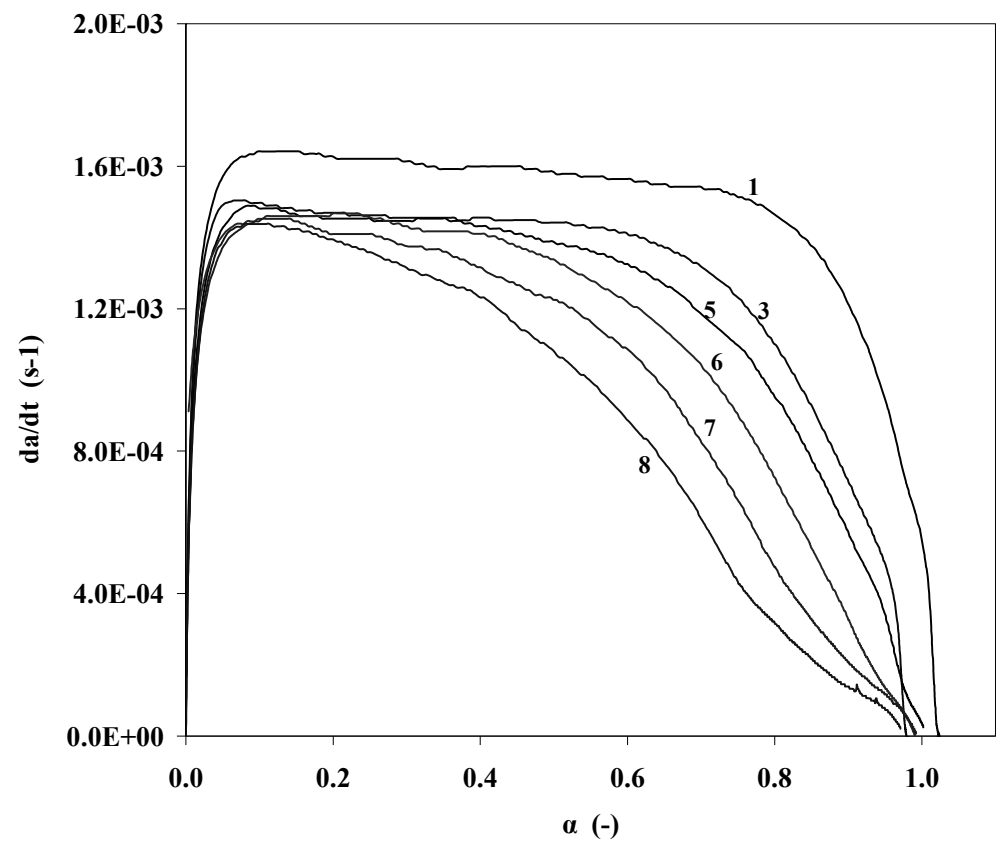

Figure 6.6: The reaction rate of the oxidation of BIC iron oxide over subsequent cycles: Reduction 30 vol \% $\mathrm{H}_{2}$, oxidation 10 vol \% $\mathrm{H}_{2} \mathrm{O}$. The amount of sample material is 204 mg.

The relative conversion rate measured in Figure 6.6 is lower compared to the relative conversion rate measured in Figure 6.5 A, although identical conditions are used (apart from the amount of iron sample). However due to the large sample amount the reaction becomes limited by the amount of steam supplied to the reactor. This can 
be most clearly seen in the first oxidation, in which the relative conversion rate is stable between a relative conversion of 0.1 and 0.8 . In this range the $\mathrm{H}_{2} /\left(\mathrm{H}_{2} \mathrm{O}+\mathrm{H}_{2}\right)$ ratio in the gas phase is about 0.7 which is similar to the equilibrium ratio for the reaction of iron to wustite. This also implies that the limiting reaction is the conversion of iron to wustite. With increasing cycle number the oxidation becomes more limited by a diffusion resistance. Furthermore the experiment performed with a large sample amount shows that the relative conversion rate at low alpha's is more or less constant (cycle number 8, Figure 6.6). This also indicates that the relative conversion rate at low alpha's is constant when a small sample amount is used, which makes the previously used assumption (using the measured max. d $\alpha / \mathrm{dt}$ in Figure 6.5) more plausible.

\subsubsection{Microstructural changes}

Figure 6.7 and Figure 6.8 show schematically the sequence of the microstructural changes of the material during the cycling up to 4 cycles. The fresh material consists of $\mathrm{Fe}_{2} \mathrm{O}_{3}$ agglomerated grains. During the first reduction with hydrogen already a BET surface area reduction from $31 \mathrm{~m}^{2} / \mathrm{g}$ to $4.7 \mathrm{~m}^{2} / \mathrm{g}$ has taken place (after reduction 1, see Figure 6.8). Figure 6.8 shows the microstructural development up to 4 redox cycles. Clearly visible is the merging of grains together and the creation of large holes. It is believed that the partly opening off of the structure counteracts the effect of reduction of free surface area of the individual grains by giving better access to reduction and oxidation gases to the inner regions of the material. At high cycle numbers the grains have to a large extent grown together. Surprisingly, the reactivity has not yet completely vanished.

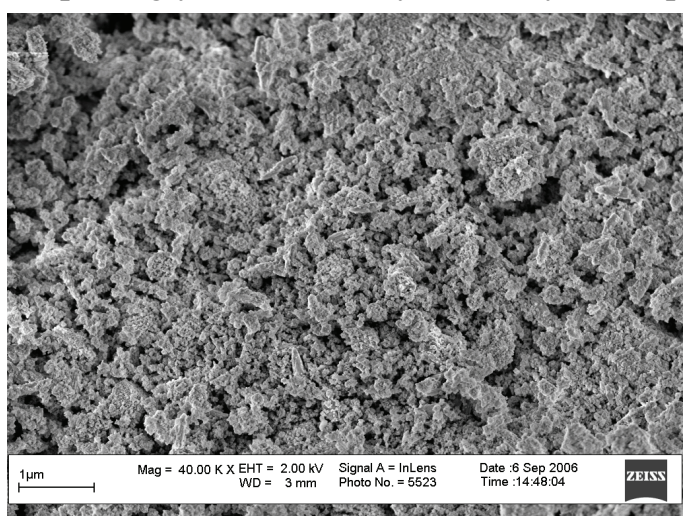

Figure 6.7: SEM picture of fresh BIC iron oxide 


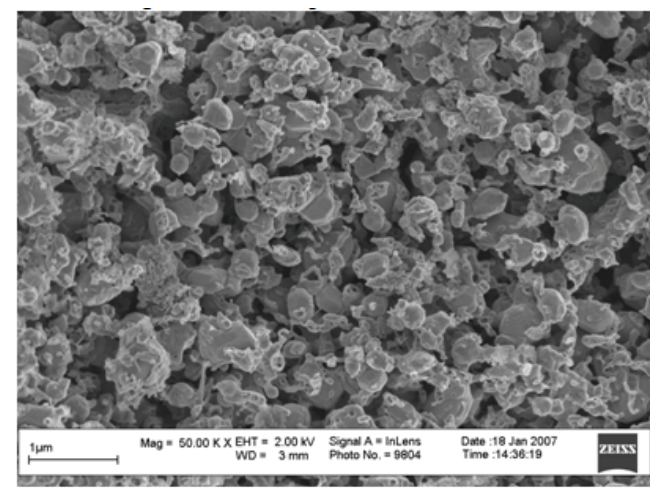

Reduction 1

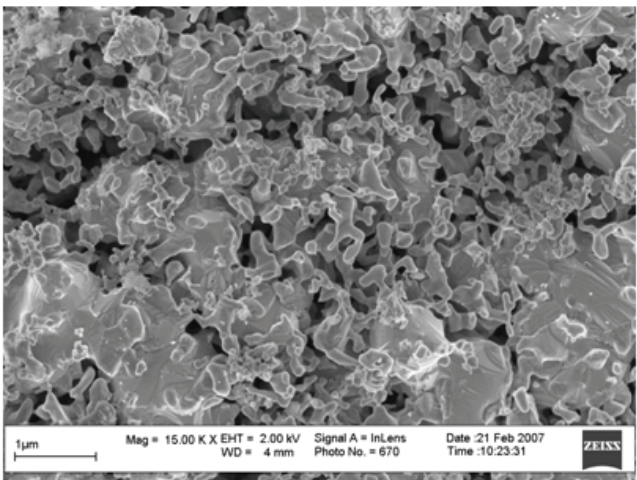

Reduction 3

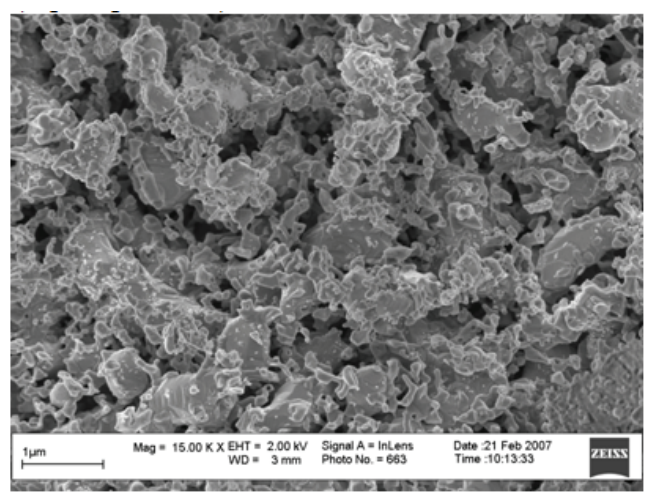

Reduction 2

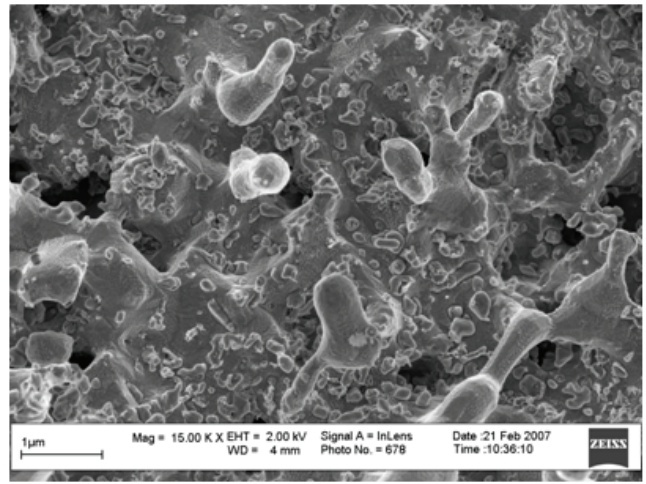

Reduction 4

Figure 6.8: SEM pictures of BIC iron oxide after reduction with 30 vol \% hydrogen.

The microstructural developments shown in Figure 6.8 indicate that the densification of the structure or merging of the grains occurs at significantly lower temperatures than normal sintering. This is caused by the forced internal material transport during reduction and oxidation, which enhances the inhomogeneous densification, as observed in sintering of porous ceramic microstructures. The resulting decrease in available surface area of the particle, which constitute of many grains, will influence the rate of reduction and oxidation.

\subsubsection{Interpretation}

It is of interest to interpret the deactivation observed over subsequent cycles with the help of equation 6.8 , but we should remember that this equation is derived for the first order contribution to $\delta z$ only, thus not for high values of alpha. In this case the relative conversion in equation 6.8 is the particle average value. 
The value of $Z_{v}$ is dependent on the relative conversion of the iron oxide and the unreactive species present, like chromium oxide and the bonded hematite. $A Z_{v}$ value can be calculated when it is assumed that the three phases $\mathrm{Fe}, \mathrm{Fe}_{1-\delta} \mathrm{O}$ and $\mathrm{Fe}_{3} \mathrm{O}_{4}$ do not exist at the same time. It is assumed that for $\alpha<0.25$ no iron has formed yet and therefore only a mixture of $\mathrm{Fe}_{3} \mathrm{O}_{4} / \mathrm{Fe}_{1-\delta} \mathrm{O}$ exists. For $\alpha>0.25$ a mixture of $\mathrm{Fe}_{1}$. ${ }_{\delta} \mathrm{O} / \mathrm{Fe}$ is present, as all $\mathrm{Fe}_{3} \mathrm{O}_{4}$ has been reduced at this point. When a high relative conversion of the material is achieved it will result in higher $Z_{\mathrm{v}}$ values (up to 1.8), especially when iron is being formed in the redox cycle.

Taking this effect in consideration, a reduction in surface area can be calculated which is shown in Figure 6.9 and is represented by the solid line. The decrease in surface area predicted by the model is compared to the relative decrease in the maximum $\mathrm{d} \alpha / \mathrm{dt}$. At the start of the reaction, the reaction rate is determined by the reaction taking place at the surface of the grain (assuming that the reaction is not limited by intra particle diffusion). This is also the highest reaction rate that can be achieved when the grain reacts, as further reaction will be slower due to the progressive increase in diffusion resistance (intra and inter grain, section 6.4.4) or the decrease in the reaction surface when a unreacted shrinking core is assumed. Therefore the change in max $\mathrm{d} \alpha / \mathrm{dt}$ is a measure of the change in the surface area of the grains.

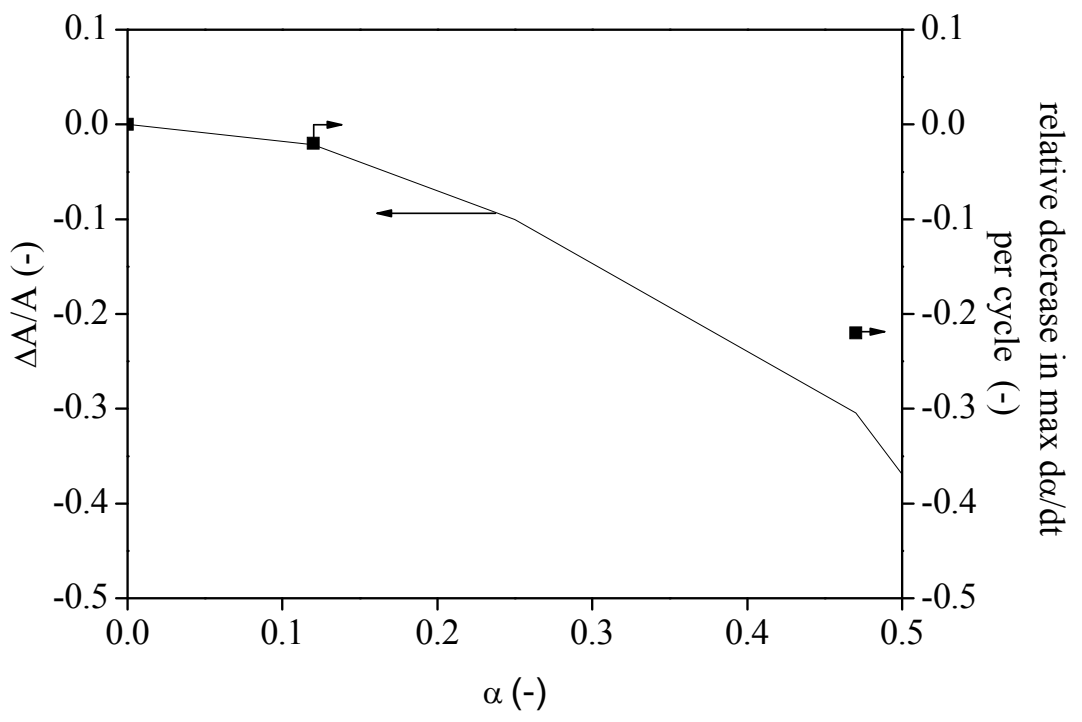

Figure 6.9: The relative decrease in surface area $(\Delta \mathrm{A} / \mathrm{A})$ for different relative conversions of the iron oxide. The solid line is the decrease expected based on equation 7. The dots are obtained from the experimental data shown in Figure 6. 
Two points, representing the relative decrease per cycle in the max. $\mathrm{d} \alpha / \mathrm{dt}$ in the first 7 cycles $\left(\left(\mathrm{d} \alpha / \mathrm{dt}_{\max }\right.\right.$, cycle $\mathrm{n}+1-\mathrm{d} \alpha / \mathrm{dt}_{\max }$, cycle $\left.\mathrm{n}\right) / \mathrm{d} \alpha / \mathrm{dt}_{\max }$, cycle $\left.\mathrm{n}\right)$, obtained from Figure $6.5 \mathrm{~B}$ and $\mathrm{C}$, is shown on the right $\mathrm{y}$-axis. It can be seen that the low decrease in surface area at a low relative conversion agrees with the proposed model. With increasing values of alpha the experimental decrease in surface area is higher, as expected from the model, but not to the extent predicted.

It should be remembered that the equations derived (6.5 to 6.8) are first order and valid at low alphas. At high alphas surface area is created in the free zones of the grains which counteracts the surface area reduction in the neck zone. On the basis of this argument the reduction slows down at high alphas and eventually will saturate. This latter can be seen in the calculated decrease in the reaction rate for the completely converted sample (Figure 6.5A) where the maximum decrease in the max. $\mathrm{d} \alpha / \mathrm{dt}$ is at $18.7 \%$ per cycle (cycle $4-12$ ). Therefore a stronger decrease in the maximum $\mathrm{d} \alpha / \mathrm{dt}$ than $20 \%$ was not found in the experiments performed.

Another explanation is that a similar relative conversion has taken place at the outer layer of the particle in the particles of Figure 6.3A and B, as the formation of iron has taken place in both experiments $(\alpha>0,25)$ and is more likely to take place at the surface of the grain. Therefore a high local $Z_{v}$ value may be adopted for both experiments, which applies to the surface of the grain.

With the help of equation 6.8 and 6.9 an interpretation can be given which for the deactivation at high cycle numbers also takes into account the structural contraction of grains in high density stacking areas and opening up of channels between the densifying particles. A cycle will lead to an increasing $\delta z$ value during oxidation and to some extent a decrease when the material is reduced again. Formally we can set $\delta z=0$ after completing a cycle, where only that part with $\delta z>0$ comes with reduction in surface area and the decrease in $z$ back to the starting value has no influence. As argued before there is no reason to assume progressive merging after some time, apart from the effect of local stress release. The bottom line anyway is that we will have to assume an effective $\delta \mathrm{z}$ value per cycle which is proportional to the reaction depth or $\alpha$ according to equation 6.9.

One striking thing to mention in this connection is that Figure $6.5 \mathrm{C}$ shows at cycle number 9 an exceptionally high value of $d \alpha / d t$. This was due to a wrong setting of the gas atmosphere during the measurement. This mistake would render the measurement range as useless, but in view of this model, we see that in this cycle the $\alpha$ value is about doubled so that $\delta \mathrm{z}$ is also twice as high than in earlier cycles and 
consequently the reduction in surface area is also about twice as high as in the earlier cycles. After this disturbance the reduction per cycle (alpha) comes back to approximately the same value as before, but the maximum reaction rate is reduced with $30 \%$.

\subsubsection{Particle modeling}

In literature many different models for the reduction and oxidation of iron oxides and iron have been proposed (see also Appendix A). One of the most widely used model for describing the transformations within the grain is the "shrinking core model", which applies to non-porous materials $[10,11]$. The "crackling core model" is generally proposed for the reduction of non-porous iron oxides resulting in a porous product during reduction [12-14]. The "grainy pellet model" (GPM) is proposed for the reduction of porous iron oxides $[15,16]$, and considers the macroscopic pellets containing a large number of grains undergoing the transformations. The BIC iron oxide used in this study is a porous iron oxide with an initially open structure, as it can be seen from the SEM pictures (Figure 6.7) and the BET analysis of the fresh material (Table 6.1).

Table 6.1: Surface area and grain size obtained from BET analysis.

\begin{tabular}{lll}
\hline & $\mathrm{BET}\left(\mathrm{m}^{2} / \mathrm{g}\right)$ & $\mathrm{r}_{\mathrm{go}}(\mathrm{nm})^{*}$ \\
\hline Fresh $\left(\mathrm{Fe}_{2} \mathrm{O}_{3}\right)$ & 31.3 & 19 \\
After reduction $(\mathrm{Fe})^{1}$ & & \\
Cycle \#1 & 4.67 & 82 \\
Cycle \#3 & 2.46 & 155 \\
Cycle \#9 & 2.05 & 186 \\
After oxidation $\left(\mathrm{Fe}_{3} \mathrm{O}_{4}\right)^{2}$ & & 269 \\
Cycle\# 2 & 2.16 & \\
\hline
\end{tabular}

*calculated using Eq 6.11

1 density sample $=7874 \mathrm{~kg} / \mathrm{m}^{3}$

2 density sample $=5154 \mathrm{~kg} / \mathrm{m}^{3}$

In this paragraph the oxidation reaction will be studied in more detail. The GPM is used to model the oxidation at particle level (Appendix A). Solid state diffusion ( $\mathrm{O}$ and $\mathrm{Fe}$ vacancies/ions) during oxidation is still not entirely clarified [17, 18]. Here it is assumed, as by [19], that oxygen diffuses in the form of $\mathrm{H}_{2} \mathrm{O}$ into the grain. In this case the phase transformation will take place at the iron/wustite and wustite/magnetite interface and the standard unreacted shrinking core model can be used. We are aware that this assumption is not backed-up by data. However, 
fundamental knowledge on the exact mechanism is lacking and the unreacted core model does allow for both reaction and diffusion limitation at the level of the grain. The particle and grain both have a spherical geometry in the applied model. The reaction at the core surface is described by a first order reaction in the steam concentration.

An observer outside the grains would see that material swells and shrinks upon oxidation and reduction leading to progressed outward surface area reduction of the particles and consequently a deactivation. The surface area of the sample can be experimentally determined by BET analysis, which can be related to the grain size at the start of the oxidation reaction by the following relation [20]:

$$
r_{g 0}=\frac{3}{A \rho_{g}}
$$

In which $A$ is the surface area per unit of mass, $r_{g 0}$ the initial grain size and $\rho g$ the density of the grain. The calculated (BET) grain sizes are shown in Table 6.1. In the present analysis we have used the observed grain growth, both from BET and SEM analysis, to model the decrease in the relative conversion rate in the oxidation by using the grainy pellet model. In the grainy pellet model the relative conversion rate can be controlled by mass transport in the gas film surrounding the particle, by inter and intra grain diffusion and by the chemical reaction itself. The effect of the swelling and shrinking of the grains in the particle during reaction will have an effect on the relative conversion rate during the progress of the reaction and can eventually lead to a change in the process by which the overall reaction is limited.

\section{Oxidation}

During oxidation the swelling of the grains in the particle will lead to a lower local voidage fraction (porosity) in the particle. The extent of swelling depends on the value of $Z_{v}$ and the conversion of the grain (equation 6.2). If the reaction is relatively fast, the conversion of the grains at the particle surface will be higher compared to the grains in the center of the particle. If the local porosity at the surface of the particle approaches at a certain time zero, it will slow down further reaction in the particle. When this pore blockage occurs, it will result in a lower conversion than expected. Pore blockage will eventually lead to a reaction that is completely limited by diffusion 
through the iron oxide material and the severity of the pore blockage will be higher when the conversion during cycling is high, as the extent of swelling and shrinking will be more. The swelling and shrinking of the grains during the reaction can be described in the GPM, by using equation 6.2. Incorporating the change in voidage in the grainy pellet model was also previously described $[13,20,21]$ for other materials.

The swelling in the oxidation will lead to a change in the local porosity, which can be calculated from the local grain size $\left(\mathrm{r}_{\mathrm{g}}(\mathrm{R}, \mathrm{t})\right)$ :

$$
\left(\frac{\mathrm{r}_{\mathrm{g}}(\mathrm{R}, \mathrm{t})}{\mathrm{r}_{\mathrm{g}_{0}}}\right)^{3}=\frac{1-\varepsilon(\mathrm{R}, \mathrm{t})}{1-\varepsilon_{0}}
$$

in which $\varepsilon(\mathrm{R}, \mathrm{t})$ is the local voidage fraction at a certain time (t) between the grains and $\varepsilon_{0}$ is the initial local voidage fraction at the start of the oxidation. In the model it is assumed that at the onset of oxidation $\varepsilon_{0}$ is not depending of the grain location in the particle. The change in the local voidage fraction affects the inter grain diffusion $\left(D_{R}\right)$ and the simplest relation for this is [13]:

$\mathrm{D}_{\mathrm{R}}(\mathrm{R}, \mathrm{t})=\mathrm{D}_{\mathrm{R} 0} \frac{\varepsilon(\mathrm{R}, \mathrm{t})}{\varepsilon_{0}}$, with $\mathrm{D}_{\mathrm{R} 0}=\mathrm{D}_{\mathrm{H}_{2} \mathrm{O}_{-} \mathrm{N}_{2}} \frac{\varepsilon_{0}}{\tau}$

The value of $\mathrm{D}_{\mathrm{R} 0}$ is related to the molecular diffusion of $\mathrm{H}_{2} \mathrm{O}$ in $\mathrm{N}_{2}\left(\mathrm{D}_{\mathrm{H}_{2} \mathrm{O} \mathrm{N}_{2}}\right)$, which is calculated with the Slattery and Bird relation for polar gases [22], the tortuosity factor $(\tau)$ and the initial porosity $\left(\varepsilon_{0}\right)$ of the particle. Typical values for the tortuosity factor are in the range of $1.5 \leq \tau \leq 10$ [22]. In the model a value of 3.2 for $\tau$ is used. The value of the mass transfer constant $\left(\mathrm{k}_{\mathrm{g}}\right)$ is calculated from the Sherwood number, which can be obtained from the Ranz and Marshall correlation [22]. An indication for the value of $\mathrm{D}_{\text {grain }}$ is taken from [23], in which the diffusion of $\mathrm{N}_{2}$ and $\mathrm{O}_{2}$ in iron is in the range of $\sim 10^{-11} \mathrm{~m}^{2} / \mathrm{s}$ and from [24], where the diffusion of metal ions in the iron oxides is $\sim 10^{-13} \mathrm{~m}^{2} / \mathrm{s}$. Also fit tests showed that a value of $\mathrm{D}_{\text {grain }}$ of $10^{-12}$ $\mathrm{m}^{2} / \mathrm{s}$ gave the best results.

So during the oxidation the solid fraction will increase with the assumption that the particle size is constant. The particle size can however change during cycling as the grains are expected to merge. Due to this merging of the grains the solid 
fraction in the particle is expected to increase which results in a smaller particle after subsequent cycling. The mass in the particle is assumed to remain constant during all cycles and therefore the change in solid fraction in between cycles can be related to the particle radius as follows:

$\frac{\mathrm{f}_{\mathrm{s} 0_{\text {cyclen }+1}}}{\mathrm{f}_{\mathrm{s}_{\text {cyclen }}}}=\frac{\mathrm{R}_{\mathrm{p}, \text { cyclen }}^{3}}{\mathrm{R}_{\mathrm{p}, \text { cyclen }+1}^{3}}$

Equations 6.11-6.14 and 6.2 are incorporated in the grainy pellet model and were used to fit the experimental data. The value of $k_{\mathrm{s}}$ is determined by fitting the model with the second oxidation using a value of $r_{\mathrm{g} 0}=0.82 \cdot 10^{-7} \mathrm{~m}$ (from Table 6.1) and a solid fraction of 0.6 . The value of $\mathrm{k}_{\mathrm{s}}$ found in this optimization is used in all further simulations with a higher cycle number. In each optimization for all subsequent cycles $r_{\mathrm{g} 0}$ and $\mathrm{f}_{\mathrm{s} 0}$ are used as optimization parameters. Examples of two fit curves are shown in Figure 6.10 and it can be seen that good fits are obtained, especially at higher cycle numbers. Note that as a result of deactivation the time to reach $60 \%$ conversion increase from 50 to 1200 seconds (Figure 6.10). 

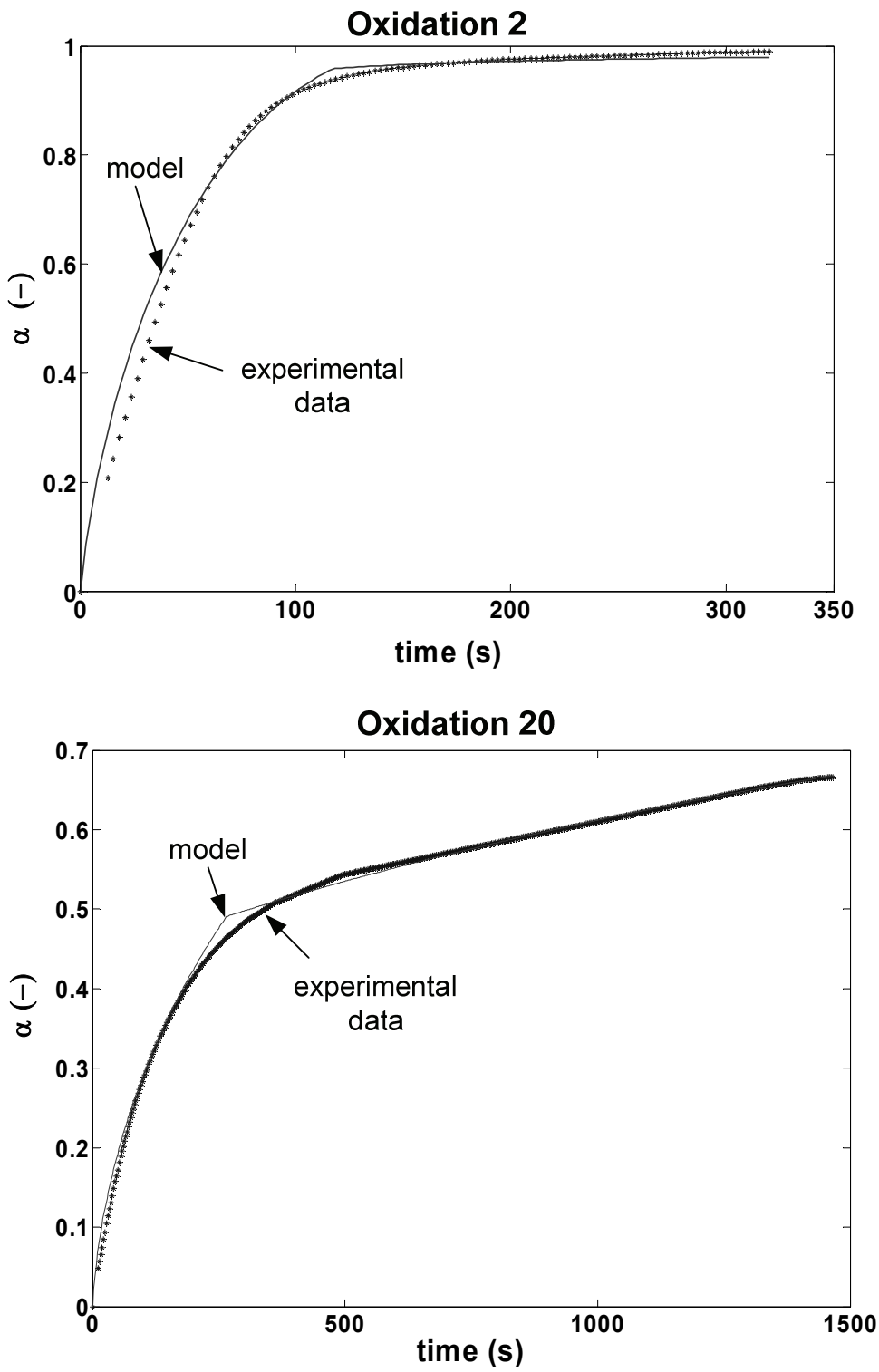

Figure 6.10: Fitted curves of the experimental obtained relative conversion time curve with the grainy pellet model for oxidation 2 and 20 . The line is the data obtained with the model and the dotted line is the experimental data. The used constants are: $D_{R 0}=1.1 \cdot 10^{-4}$ $\left(\mathrm{m}^{2} / \mathrm{s}\right) \quad D_{\text {grain }}=1 \cdot 10^{-12}\left(\mathrm{~m}^{2} / \mathrm{s}\right) \quad k_{\mathrm{s}}=5.5 \cdot 10^{-5}(\mathrm{~m} / \mathrm{s})$ and $\mathrm{k}_{\mathrm{g}}=0.3 \mathrm{~m} / \mathrm{s}, \mathrm{Zv}=1.7, \mathrm{~T}=800{ }^{\circ} \mathrm{C}$ and $\mathrm{C}_{\mathrm{H} 2 \mathrm{O}, 0}=1.12 \mathrm{~mol} / \mathrm{m}^{3}$. 


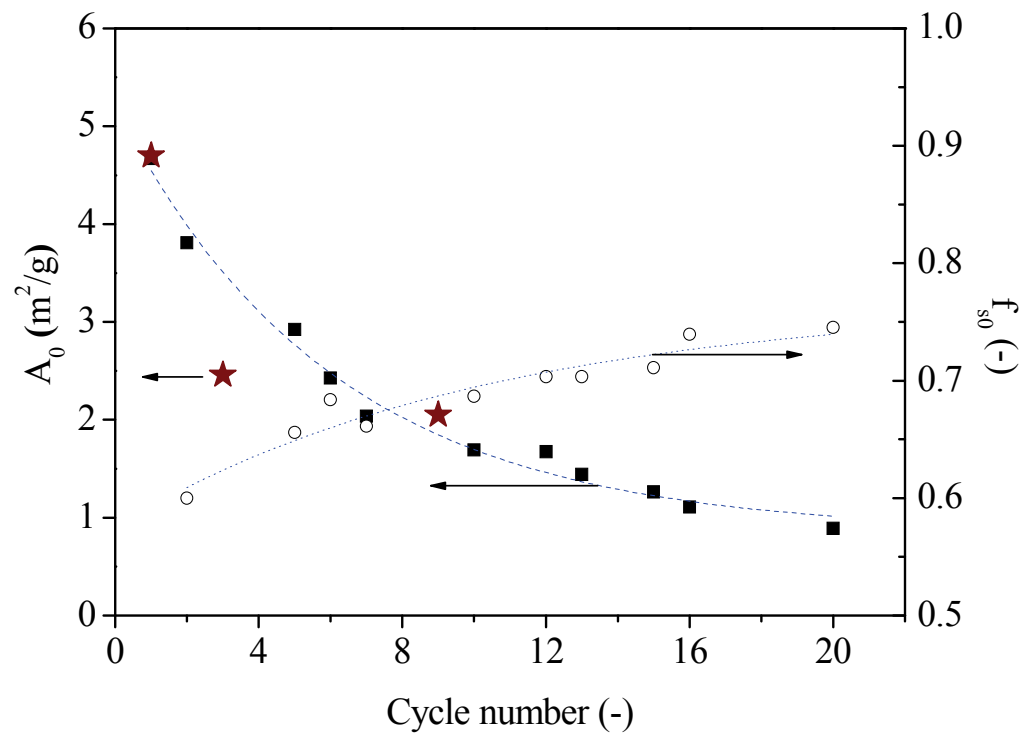

Figure 6.11: Estimated surface area and solid fraction from fitting experimental data with the GPM. The used constants are: $D_{R}=1 \cdot 10^{-4}\left(\mathrm{~m}^{2} / \mathrm{s}\right), D_{\text {grain }}=1 \cdot 10^{-12}\left(\mathrm{~m}^{2} / \mathrm{s}\right) \mathrm{k}_{\mathrm{s}}=5.5 \cdot 10^{-5}(\mathrm{~m} / \mathrm{s})$ and $\mathrm{k}_{\mathrm{g}}=0.3 \mathrm{~m} / \mathrm{s}, \mathrm{Zv}_{\mathrm{v}}=1.7, \mathrm{~T}=800{ }^{\circ} \mathrm{C}$ and $\mathrm{C}_{\mathrm{H} 2 \mathrm{O}, 0}=1.12 \mathrm{~mol} / \mathrm{m}^{3}$. The symbol represents the surface area obtained with BET analysis.

The obtained results for $A_{0}\left(r_{g}\right)$ and $f_{s 0}$ are presented in Figure 6.11. Figure 6.11 shows a steady reduction of the surface area due to the increase in $r_{g 0}$ and $f_{s 0}$ over subsequent cycles. The measured surface area obtained with BET analysis is also shown in the figure and it can be seen that a good correspondence is obtained with the area from the fitted grain size.

Initially the relative conversion rate is high as the grains are small. However due to the increasing grain size the relative conversion rate becomes more limited by the intra grain diffusion. Furthermore the inter grain diffusion becomes also limited with increasing cycle number; as the particles become more dense upon merging, the swelling will limit the inter grain diffusion more rapidly over subsequent cycles. This can be observed in Figure 6.3A. For the second oxidation a concave shape is observed (indicating combined reaction and external mass transfer), however with increasing cycle number a tail starts to form for a higher $\alpha$, which increases in length with increasing cycle number. This tail is the slow oxidation due to diffusion limitations (predominantly inter grain). Simultaneous with the GPM model this increase in the diffusion limitation can be completely related to the increase in the grain size and solid fraction in the particle. This can be seen when the predicted dimensionless $\mathrm{H}_{2} \mathrm{O}$ 
concentration profile over the dimensionless radius of the particle is plotted for different relative conversions (Figure 6.12) using the grainy pellet model. Only a minor $\mathrm{H}_{2} \mathrm{O}$ concentration profile is present for oxidation 2 for different relative conversions. Even when the conversion is near completion the inter grain diffusion hardly plays a role in the relative conversion rate. In this case the rate is determined by a combination of external mass transfer, intra grain diffusion and chemical kinetics. With subsequent cycles this $\mathrm{H}_{2} \mathrm{O}$ concentration profile is more influenced with increasing relative conversion. As can be seen in Figure 6.12, the $\mathrm{H}_{2} \mathrm{O}$ concentration drops to nearly zero at $R / R_{p}=0.8$ when a relative conversion of 0.49 is obtained. This decrease is caused by the fact that when the outer grains are converted the voidage fraction is locally reduced. Ones the voidage fraction reaches a minimum value close to zero, the inter grain diffusion coefficient will be very small. The inter grain diffusion when complete conversion of the grains is obtained is in the range of $10^{-9}$ $\mathrm{m}^{2} / \mathrm{s}$, which is similar to Knudsen diffusion in small pores. 

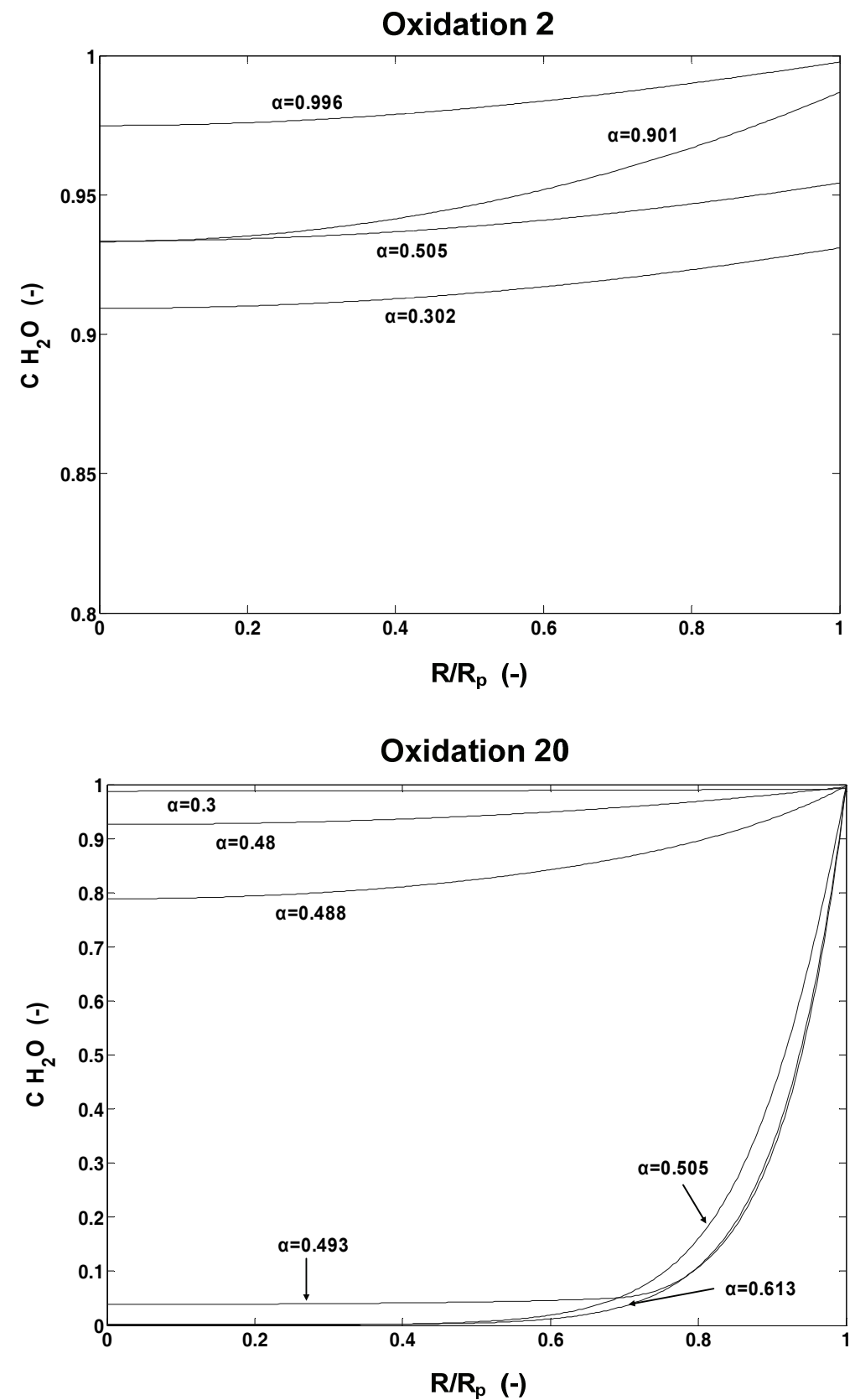

Figure 6.12: Dimensionless concentration profile in the dimensionless particle obtained from the grainy pellet model for different relative conversions. The results for oxidation 2 and 20 are shown. Centre of the particle: $R / R p=0$; particle boundary: $R / R p=1$. 


\section{Reduction}

When the reduction is performed an increase in the porosity can be expected, which would increase the diffusion of hydrogen to the grains and may even to some extent recover the initial structure. However another effect may limit the progress of the reduction, namely the formation of iron. It was already mentioned that the formation of iron can limit the reaction rate, as diffusion through iron is very slow. The grainy pellet model can be applied with a reduced diffusion in the grains. When the grains are small the limitation on the reaction rate by the formation of iron will be small. However when the grain size grows with subsequent cycles, the limitation of diffusion of oxygen will be of increasing importance in the total reaction rate. Eventually the reduction may be completely limited by this diffusion in the grain when the porosity of the particle is decreasing. This was also observed from the experimental data.

\subsection{Discussion}

In the present study almost pure iron oxide ( $88 \mathrm{wt} \%$ ) has been used so that, according to the sintering model presented, the adjacent particles will initially merge upon swelling in the oxidation phase. Next to this the constant cycling stimulates self diffusion of the ions in the iron oxide which obviously enhances the sintering effect. A simple relation for the decrease in surface area caused by the swelling of the iron oxide during cycling is derived, on the basis of a sintering model. This derived simple model is however only valid at low conversions of the iron oxide and limited redox cycle numbers, as the physical changes in the material become more complex with a higher relative conversion and with progressive cycling. For example the local variations in stacking density of the grains will lead to rapidly densifying areas and also locally opening up of the structure. A more sophisticated model to describe the sintering can be derived based on the presented theory, in which case the change in the number of contacts each grain has with it neighbors and the increase in surface area in the neck zones of the grains should be incorporated.

The enhanced sintering and reorganization of the stacking structure, also observed in the microstructural development as well as the decrease in the BET surface area, is explained on the basis of an old model, initially developed to explain sintering induced by temperature only. The presence of $\mathrm{Cr}_{2} \mathrm{O}_{3}$, which is able to form a 
spinel with the $\mathrm{Fe}_{2} \mathrm{O}_{3}$ will probably, to some extent, decrease the deactivation rate as it is known that $\mathrm{Cr}_{2} \mathrm{O}_{3}$ can reduce the sintering rate [4, 25-27].

It should be noted that the experiments performed are limited to a temperature of $800^{\circ} \mathrm{C}$. Increasing the temperature will probably result in a higher deactivation rate as the transport of material will enhance [3]. Also the conversion will be higher when the used $\mathrm{H}_{2} / \mathrm{H}_{2} \mathrm{O}$ mixtures are applied in the reduction, resulting in a higher deactivation rate.

On the basis of the analysis given, it can be concluded that incorporation of an inert material, preferably of the same particle size distribution, up to few tens of volume percent to more or less keep a significant amount of the particles apart can be a remedy to reduce the development of internal stresses which are responsible for enhanced sintering effects. In this way neck zone formation is suppressed and lower deactivation rates, even with higher conversions, may be expected.

\subsection{Conclusions}

The following main conclusions can be made:

- The deactivation of the iron oxide is caused by a decrease in the surface area of the material (sintering). This is, amongst others, visually observed from SEM pictures.

- The deactivation rate of iron oxide in a redox cycle is dependent on the relative conversion of the material. A high relative conversion of the material will lead to a stronger deactivation.

- The deactivation is described with a simple relation derived from purely geometrical arguments, which can predict the decrease of the surface area for a low relative conversion of the material.

- The relative conversion obtained during reduction is linearly dependent on the $\mathrm{H}_{2} \mathrm{O}$ content in the $\mathrm{H}_{2} / \mathrm{N}_{2}$ mixture. When a ratio of 0.4 $\left(\mathrm{H}_{2} \mathrm{O} /\left(\mathrm{H}_{2}+\mathrm{H}_{2} \mathrm{O}\right)\right)$ is used, only a relative conversion of $10-12 \%$ can be achieved.

- The grainy pellet model (GPM), adjusted for the swelling of the material during oxidation, could fit the experimental data well. Fitting the experimental data with the GPM, resulted in a prediction of the grain growth and an increase of the solid fraction over subsequent cycles. This 
grain growth over subsequent cycles could explain the observed deactivation well.

\subsection{Nomenclature}

\begin{tabular}{|c|c|c|}
\hline$\alpha$ & $(-)$ & Relative conversion of the iron oxide \\
\hline$\alpha_{\mathrm{g}}$ & $(-)$ & Relative conversion of a single grain \\
\hline $\mathrm{A}^{\circ}$ & $\left(\mathrm{m}^{2}\right)$ & Surface area \\
\hline $\mathrm{A}_{0}$ & $\left(\mathrm{~m}^{2}\right)$ & Initial surface area at the start of the oxidation \\
\hline $\mathrm{C} \mathrm{H}_{2} \mathrm{O}$ & $(-)$ & $\begin{array}{l}\text { Dimensionless steam concentration in the particle } \\
\left(\mathrm{CH}_{2} \mathrm{O} / \mathrm{CH}_{2} \mathrm{O}, 0\right)\end{array}$ \\
\hline $\mathrm{CH}_{2} \mathrm{O}, 0$ & $\left(\mathrm{~mol} / \mathrm{m}^{3}\right)$ & Steam concentration in the bulk \\
\hline$\gamma$ & $\left(\mathrm{J} / \mathrm{m}^{2}\right)$ & Surface tension \\
\hline $\mathrm{D}_{\text {grain }}$ & $\left(\mathrm{m}^{2} / \mathrm{s}\right)$ & $\begin{array}{l}\text { Overall diffusion coefficient of the solid state } \\
\text { diffusion in a grain }\end{array}$ \\
\hline$D_{R}$ & $\left(\mathrm{~m}^{2} / \mathrm{s}\right)$ & Diffusivity of gas in between the grains \\
\hline $\mathrm{D}_{\mathrm{R} 0}$ & $\left(\mathrm{~m}^{2} / \mathrm{s}\right)$ & $\begin{array}{l}\text { Initial diffusivity of gas in between the grains in } \\
\text { the first oxidation reaction cycle }\end{array}$ \\
\hline $\mathrm{D}_{\mathrm{H}_{2} \mathrm{O}_{-} \mathrm{N}_{2}}$ & $\left(\mathrm{~m}^{2} / \mathrm{s}\right)$ & Molecular gas diffusion \\
\hline$\varepsilon$ & $(-)$ & Voidage fraction during oxidation \\
\hline$\varepsilon_{0}$ & $(-)$ & Initial voidage fraction at the start of the oxidation \\
\hline $\mathrm{f}_{\mathrm{s}}$ & $(-)$ & Solid fraction \\
\hline$f_{s 0}$ & $(-)$ & Initial solid fraction \\
\hline $\mathrm{G}$ & $(-)$ & Coordination number \\
\hline $\bar{G}$ & $(-)$ & Average coordination number \\
\hline$\eta$ & $(\mathrm{J} / \mathrm{kg})$ & Internal transport mechanism \\
\hline$\theta$ & $(-)$ & Densification factor \\
\hline $\mathrm{k}_{\mathrm{s}}$ & $(\mathrm{m} / \mathrm{s})$ & Surface reaction rate constant \\
\hline $\mathrm{k}_{\mathrm{g}}$ & $(\mathrm{m} / \mathrm{s})$ & Mass transfer coefficient \\
\hline $\mathrm{O}$ & (mole) & Amount of oxygen atoms \\
\hline $\mathrm{P}$ & $(\mathrm{Pa})$ & Pressure \\
\hline$\rho$ & $(\mathrm{kg} / \mathrm{m} 3)$ & Density \\
\hline$\rho_{0}$ & $(\mathrm{~kg} / \mathrm{m} 3)$ & Initial density \\
\hline$R_{p}$ & (m) & Radius of the particle \\
\hline $\mathrm{R}$ & (m) & Radial location in the particle \\
\hline $\mathrm{R}_{\mathrm{g}}$ & $(\mathrm{J} / \mathrm{molK})$ & Universal gas constant (8.31) \\
\hline$r_{g}$ & (m) & Grain radius \\
\hline$r_{\mathrm{gi}}$ & (m) & Radius of the unreacted grain \\
\hline $\mathrm{r}_{\mathrm{g} 0}$ & (m) & Initial grain radius \\
\hline $\mathrm{S}_{0}$ & (mol) & Amount of reactive oxygen atoms in the sample \\
\hline $\mathrm{T}$ & (K) & Temperature \\
\hline $\mathrm{t}$ & (s) & Time \\
\hline$\tau$ & $(-)$ & Turtuosity \\
\hline$\varphi \mathrm{H}_{2}$,in & $\left(\mathrm{m}^{3} / \mathrm{s}\right)$ & Flow of hydrogen to the reactor \\
\hline$\varphi \mathrm{H}_{2}$, zero & $\left(\mathrm{m}^{3} / \mathrm{s}\right)$ & $\begin{array}{l}\text { Decrease in hydrogen flow obtained from the } \\
\text { "zero" experiment }\end{array}$ \\
\hline$\varphi \mathrm{N}_{2}$ & $\left(\mathrm{~m}^{3} / \mathrm{s}\right)$ & Flow of nitrogen to the reactor \\
\hline
\end{tabular}




\begin{tabular}{|lll|}
\hline$Z_{\mathrm{v}}$ & $(-)$ & $\begin{array}{l}\text { Swelling parameter, equal to the molar volume of } \\
\text { the product divided by the molar volume of the } \\
\text { reactant }\end{array}$ \\
$\mathrm{z}$ & $(-)$ & $\begin{array}{l}\text { Densification parameter, equal to the free grain } \\
\text { radius divided by half the center-to-center distance } \\
\text { Average densification parameter }\end{array}$ \\
\hline$z$ & $(-)$ &
\end{tabular}

\subsection{Literature}

1 M. Thaler, V. Hacker, M. Anilkumar, J. Albering, J.O. Besenhard, H. Schrottner, M. Schmied, Int. J. of Hydrogen Energy 31 (2006) p. 2025-2031.

2 H. Kindermann, M. Kornberger, J.Hierzer, J.O. Besenhard, J. of Power Sources 145 (2005) p. 697-701.

3 V. Galvita, T. Hempel, H. Lorenz, L. Rihko-Struckmann, K. Sundmacher, Ind. \& Eng. Chem. Res. 47 (2008) p. 303-310.

4 V. Galvita, K. Sundmacher, Chem. Eng. J. 134 (2007) p. 168-174.

5 L.K. Doraiswamy, M.M. Sharma, Heterogeneous reactions: analysis, examples, and reactor design. Vol. I: Gas-Solid and Solid-Solid reactions, John Wiley \& Sons Inc., New York, 1984.

6 H.J. Veringa, J. of Mat. Sci., 26 (1991) p. 5985-5995.

7 J. Slattery, K-Y. Peng, A.M. Gadalla, N. Gadalla, Ind. \& Eng. Chem. Res. 34 (1995) p. 3405-3410.

8 E. Arzt, Acta Metallica, 30 (1982) p. 1883-1890.

9 H.J. Veringa, J. of Mat. Sci. 28 (1993) p. 2757-2762.

10 M. Tokuda, H. Yoshikoshi, M. Ohtani, ISIJ Int. 13 (1973) p. 350-362.

11 R.H. Spitzer, F.S. Manning, W.O. Philbrook, Trans. Metall. Soc. AIME, 236 (1966) p. 726-741.

12 T. Sharma, Int. J. of Min. Process., 49 (1997) p. 201-206.

13 O. Levenspiel, Chemical Reactor Omnibook, Corvallis OR, Distr. by OSU Book Stores, 1979.

14 J.Y. Park, O. Levenspiel, Chem. Eng. Sci., 30 (1975) p. 1207-1214.

15 A. Bonalde, A. Henrique, M. Manrique, ISIJ Int., 45 (2005) p. 1255-1260.

16 M.S. Valipour, M.Y. Motamed Hashemi, Y. Saboohi, Adv. Powder Tech., 17 (2006) p. 277-295.

17 L. Tomlinson, N.J. Cory, Corr. Sci., 29 (1989) p. 939-965.

18 S.R.J. Saunders, M. Monteiro, F. Rizzo, Progr. in Mat. Sci., 53 (2008) p. 775837. 
19 H. Imanishi, Int. J. of Chem. Reac. Eng. 5 (2007) p. 1-7.

20 P.V. Ranade, D.P. Harrison, Chem. Eng. Sci., 34 (1979) p. 427-432.

21 C.W. Chang, J. Szekely, Chem. Eng. Sci., 34 (1979) p. 1072-1075.

22 J. Szekely, J.W. Evans,H.Y. Sohn, Gas-solid reactions, Academic Press Inc., New York, 1976.

23 T. Taguchi, Proc. Schl. Eng. Tokai. Univ. 28 (2003) p. 9-11.

24 J.O. Edstrom, G. Bitsanies, J. of Metals (1955) p. 760-765.

25 C. Rhodes, B.P. Williams, F. King, G.J. Hurtchings, Cat. Comm., 3 (2002) p. 381-384.

26 S. Fukase, T. Suzuka, Can. J. of Chem. Eng., 72 (1994) p. 272-278.

27 K. Otsuka, C. Yamada, T. Kaburagi, S. Takenaka, Int. J. of Hydrogen Energy 28 (2003) p. 335-342. 


\title{
Chapter 7
}

\section{Process design study for the production of hydrogen from pyrolysis oil in the steam-iron process}

\begin{abstract}
The overall energy efficiency of the production of pure hydrogen using the pyrolysis oil driven steam-iron process is evaluated for different process conditions. The process consists of a two-step process (reduction with pyrolysis oil, oxidation with steam) from which pure hydrogen can be obtained, without purification steps. An optimum energy efficiency of 53\% is achieved when the equilibrium conversion is obtained in the redox cycle at $800{ }^{\circ} \mathrm{C}$. When assuming chemical equilibrium, increasing the process temperature results in a lower process efficiency due to a large amount of unreacted steam that needs to be condensed to separate the hydrogen product. Using experimental data in the process simulation a higher energy efficiency is obtained at $920{ }^{\circ} \mathrm{C}(39 \%)$ compared to the efficiency at $800{ }^{\circ} \mathrm{C}(29 \%)$. This is caused by the low conversion in the reduction at $800{ }^{\circ} \mathrm{C}$. Improving the iron oxide material, to enhance the reduction with pyrolysis oil at $800{ }^{\circ} \mathrm{C}$ is therefore suggested.
\end{abstract}




\subsection{Introduction}

Proposed routes for producing hydrogen from solid biomass contain a substantial amount of different reaction steps [1], mainly to purify the hydrogen from gaseous and solid byproducts. Typical projected hydrogen from biomass process efficiencies are in the range of 50-58 \% [2]. The purification of the gas involves several steps and therefore alternative processes, which require none or less purification, can be beneficial.

The main advantage of the steam-iron process is the relative simplicity of the process design. The gasification and reduction can be performed in one single step, by spraying the oil directly over a bed of catalytic or non-catalytic iron oxides. The second step, the oxidation, results in the formation of hydrogen and there are no difficult or expensive separation steps required, since the hydrogen product is essentially $\mathrm{CO}$ free. This is important, because $\mathrm{CO}$ can poison the fuel cell [3]. A disadvantage of the process could be the recirculation of the iron oxide solids, which can be substantial if an optimal conversion of the pyrolysis oil in the reduction is desired (Chapter 4).

In the present study, a technical evaluation of the industrial applicability of such a system is performed. A structural design method [4] (Figure 7.1) is applied to develop a process flow sheet. The process conditions are selected from experimental and theoretical data (based on thermodynamics) and used to evaluate the process. Simulation results from flowsheet program Aspen Plus ${ }^{\mathrm{TM}}$ are linked with models created in Microsoft Excell to develop mass and heat balances for the process. These combined balances are used to compare process efficiencies at different process conditions ( $\mathrm{T}$ and $\mathrm{P}$ ) and configurations. 


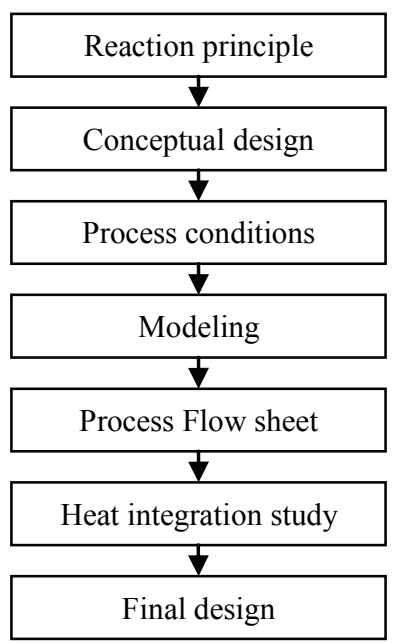

Figure 7.1: Steps to create a process design [4].

\subsection{Conceptual design}

The process can be split in two separate parts. First, there is the reduction, where iron oxide is reduced with pyrolysis oil. The products of the reduction are essentially $\mathrm{CO}_{2}$ and $\mathrm{H}_{2} \mathrm{O}$, since these are the products of the reduction reactions. Furthermore unreacted tar, coke, hydrocarbons, $\mathrm{CO}$ and $\mathrm{H}_{2}$ can be expected and can be reused in the reduction or used for energy supply in the process. Recycling of the spent reducing gas will only be effective when (part) of the reduction products $\left(\mathrm{CO}_{2}\right.$ or $\mathrm{H}_{2} \mathrm{O}$ ) can be separated or when by-products, like hydrocarbons, are converted in a recycle by reforming to $\mathrm{H}_{2}$ and $\mathrm{CO}$.

The second step is the oxidation, where the hydrogen is produced from the reaction of steam with the reduced iron oxide. The hydrogen has to be sufficiently pure ( $99.9 \mathrm{vol} \%$ and $\mathrm{CO}$ free) and has to be delivered at a pressure of minimal $20 \mathrm{bar}$ for commercial purposes. To be able to fulfil the requirement of continuous operation, the iron oxide particles need to be exchanged between the reduction and oxidation. Figure 7.2 gives a schematic representation of this conceptual design.

Both reduction and oxidation are performed in a fluidized bed. In this way circulation of the iron oxide between the reductor and oxidator can be achieved. Furthermore, heat exchange in a fluidized bed is good, which is important when the pyrolysis oil is gasified directly in the fluidized bed. 


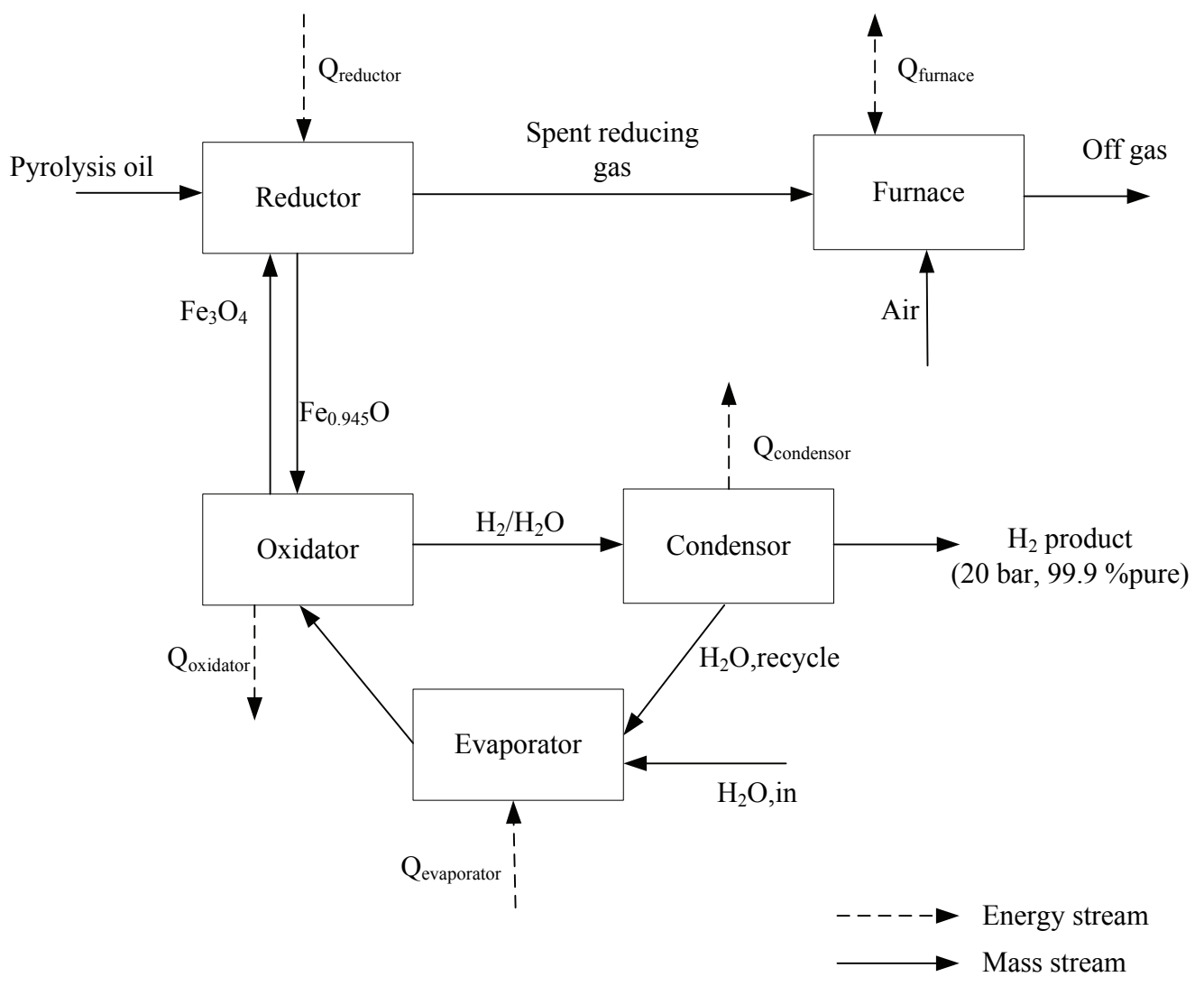

Figure 7.2: Conceptual design of the steam-iron process with pyrolysis oil as feedstock.

Table 7.1: Definitions of energy required for the different process steps.

\begin{tabular}{|ll|}
\hline Qreductor & $\begin{array}{l}\text { Energy demand of the reductor reactor, in which both gasification of oil } \\
\text { and reduction take place }\end{array}$ \\
$\mathrm{Q}_{\text {furnace }}$ & $\begin{array}{l}\text { Energy demand/production in the furnace after burning the spent gases } \\
\text { with an excess of air. }\end{array}$ \\
Q $_{\text {oxidator }}$ & Energy produced in the oxidation \\
$\mathrm{Q}_{\text {evaporator }}$ & Energy required to heat water to hot steam \\
$\mathrm{Q}_{\text {condenser }}$ & Energy obtained when the hot product gas is condensed \\
\hline
\end{tabular}

The amount of $\mathrm{Fe}_{3} \mathrm{O}_{4}$ that can be reduced by a certain amount of pyrolysis oil is determined in the reduction. This means that the quantity of hydrogen product per amount of pyrolysis oil is determined in the reduction and therefore process optimization starts with the reduction. The efficiency of the process is determined in terms of an overall process energy efficiency, where the heating values of the feedstock and the product are used (Appendix C), as well as additional energies 
required in the process as heat or electric power. The definition of the energy requirements of the process steps is given in Table 7.1 and shown in Figure 7.2. Furthermore heat exchange between the different streams can minimize the overall energy demand of the process.

The net energy requirement $(\mathrm{Q})$ of the process is used in the calculation of the process energy efficiency. Furthermore the compression of hydrogen to 20 bar was taken into account in the total process efficiency.

$$
\eta_{\text {process }}=\frac{\mathrm{M}_{\mathrm{H}_{2}} \cdot \mathrm{LHV}_{\mathrm{H}_{2}}}{\mathrm{LHV}_{\text {oil }}+\frac{\mathrm{Q}}{\lambda_{\text {heat }}}+\frac{\mathrm{W}_{\text {comp }}}{\lambda_{\text {comp }}}}
$$

Where:

$\mathrm{Q}=$ the net energy requirement for the process in $\mathrm{MJ} / \mathrm{kg}$ oil.

$\mathrm{W}_{\text {comp }}=$ the net energy requirement for compression of the hydrogen in $\mathrm{MJ} / \mathrm{kg}$ oil.

$\lambda_{\text {heat }}=$ the efficiency to produce the heat required in the process. A value of $\lambda_{\text {heat }}=0.8$ is used in the calculations

$\lambda_{\text {elec }}=$ the electrical efficiency to compress gas. A value of $\lambda_{\text {elec }}=0.4$ is used in the calculations.

$\mathrm{M}_{\mathrm{H} 2}=$ the amount of hydrogen (in $\mathrm{kg}$ ) produced per $\mathrm{kg}$ oil.

$\mathrm{LHV}_{\mathrm{H} 2}$ and $\mathrm{LHV}_{\text {oil }}=$ The lower heating value of hydrogen $\left(\mathrm{MJ} / \mathrm{kg} \mathrm{H} \mathrm{H}_{2}\right)$ and oil $(\mathrm{MJ} / \mathrm{kg}$ oil).

\subsection{Process conditions selection}

The optimum temperature and pressure have to be determined for the process design. As mentioned before, these conditions have an influence on the reaction equilibrium in both reduction and oxidation.

\subsubsection{Temperature}

\section{Theoretical approach}

A theoretical approach (based on thermodynamic data), taking hydrogen production as well as energy demands into account, show an optimum process temperature at $727^{\circ} \mathrm{C}$ (Chapter 2). The process efficiency has a maximum because two temperature effects counteract each other, namely an improved reduction potential 
with pyrolysis oil at high temperatures and a better steam conversion in the oxidation step at low temperatures.

\section{Experimental approach}

Based on previous experimental work the two following effects of temperature on the use of pyrolysis oil in the reduction of iron oxide are found:

1. A high temperature is beneficial for the reduction potential of the pyrolysis oil. Experimental studies show that the gasification of pyrolysis oil is strongly temperature dependent (Chapter 3). A drastic increase in the $\mathrm{H}_{2} / \mathrm{H}_{2} \mathrm{O}$ and $\mathrm{CO} / \mathrm{CO}_{2}$ ratios in the gas phase at temperatures above $850^{\circ} \mathrm{C}$ is observed, which is caused by the increase in the reforming of $\mathrm{C}_{2+}$ hydrocarbons as well as the increase in the conversion of oil to the gas phase.

2. Complete conversion of pyrolysis oil to the gas phase can be obtained at high temperatures $\left(>900^{\circ} \mathrm{C}\right)$ over a catalytic iron oxide bed, which is mainly caused by the enhanced reaction of carbon with the iron oxide (Chapter 4). A lower temperature results in a lower carbon to gas conversion and in a slow reaction of deposited carbon with the iron oxide.

Following this discussion it can be concluded that a low temperature $\left(727^{\circ} \mathrm{C}\right)$ is favourable for the redox cycle from a theoretic point of view. However experimental data showed that this low temperature is not sufficient to use pyrolysis oil effectively in the redox cycle. The effect of a high and low temperature on the process efficiency will be evaluated at $800{ }^{\circ} \mathrm{C}$ and $920^{\circ} \mathrm{C}$.

\subsubsection{Iron oxide to oil mass ratio $\left(\mathrm{Fe}_{3} \mathrm{O}_{4} /\right.$ oil $)$}

Besides the temperature, the oil to hydrogen conversion is dependent on the $\mathrm{Fe}_{3} \mathrm{O}_{4}$ /oil ratio. A high $\mathrm{Fe}_{3} \mathrm{O}_{4} /$ oil ratio $(>100)$, results in a low conversion of the iron oxide, which is beneficial for the production of hydrogen. This is caused by the decrease in the reduction rate when the iron oxide is partly reduced, resulting in a lower overall pyrolysis to hydrogen production in the process (Chapter 3). However, it will be very energy consuming when large quantities of iron oxide are circulated between the oxidator and reductor. Therefore a ratio of 60 , which is close to normal circulation rates of solids in biomass gasifiers [5], is chosen. The pumping requirements for the circulation of the iron oxides is not taken into account in the 
present analysis.

\subsubsection{Pressure}

Hydrogen has to be delivered at high pressure ( $>20$ bar), which means that the hydrogen product should be compressed when the hydrogen is obtained at a lower pressure. Operating the entire process at high pressure would eliminate this extra step. The benefit of using pyrolysis oil, compared to solid biomass, is that it is possible to compress it to 20 bar without difficulties. The effect of pressure on the gaseous reactions taking place in the redox cycle however, should be taken into account.

Literature study shows [6] that a change in pressure does not have an effect on the $\mathrm{H}_{2} / \mathrm{H}_{2} \mathrm{O}$ and $\mathrm{CO} / \mathrm{CO}_{2}$ equilibrium in the Bauer-Glaessner diagram. This is logical, since the reduction and oxidation reactions with $\mathrm{Fe}_{3} \mathrm{O}_{4}$ and $\mathrm{Fe}_{0.945} \mathrm{O}$ are all equimolar reactions with respect to the gaseous compounds. The reaction rate for the gas solid reactions will probably increase with increasing pressure. The equilibrium of the reduction with solid carbon on the other hand is expected to worsen with increasing pressure.

The gasification of pyrolysis oil at elevated pressure will mainly suppress the reforming of hydrocarbons resulting in a lower reducing capacity of the oil. The hydrogen potential in the redox cycle, based on equilibrium calculations, is plotted for different conditions in Figure 7.3.

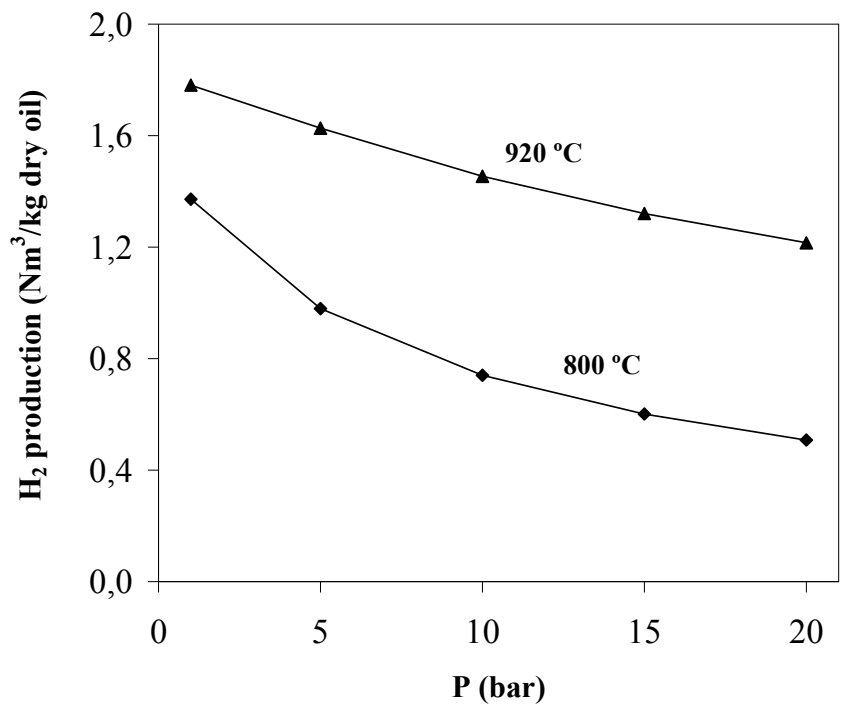

Figure 7.3: Hydrogen potential at different temperatures and pressures. 
Figure 7.3 shows a strong decrease of the hydrogen potential when pyrolysis oil is gasified with increasing pressure at $800{ }^{\circ} \mathrm{C}$. This is caused by the increased formation of hydrocarbons, like $\mathrm{CH}_{4}$ and $\mathrm{C}_{2}{ }^{+}$, which do not contribute to the reduction. The decrease in the hydrogen production is less significant at a temperature of $920^{\circ} \mathrm{C}$. These results indicate that it is possible to operate this process at a higher pressure of $20 \mathrm{bar}$, but only if temperatures are high $\left(\mathrm{T}>900{ }^{\circ} \mathrm{C}\right)$. This conclusion is however only valid when it is assumed that gas equilibrium is obtained in the gas phase when oil is gasified.

\subsubsection{Process conditions}

The discussion on the pressure and temperature revealed that three interesting cases need to be evaluated. A high temperature $\left(920^{\circ} \mathrm{C}\right)$ at $1 \mathrm{bar}$, a high temperature $\left(920{ }^{\circ} \mathrm{C}\right.$ ) at 20 bar and a low temperature of about $800{ }^{\circ} \mathrm{C}$ at 1 bar (Table 7.2). These cases will be evaluated based on equilibrium assumptions and by using experimental data (obtained from Chapter 4).

The carbon that is not converted to the gas phase in case $1 \mathrm{~b}(25 \%$ of the carbon input), is not contributing in the reduction reaction, but is combusted in the furnace for heat production.

Table 7.2: Temperature, pressure and main assumptions used in the reduction reaction for the different cases.

\begin{tabular}{|c|c|c|c|}
\hline Case name & $\mathrm{T}\left({ }^{\circ} \mathrm{C}\right)$ & $\mathrm{P}$ (bar) & Assumptions \\
\hline $1 \mathrm{a}$ & 800 & 1 & $\begin{array}{l}\zeta_{\mathrm{C} \text { to gas }}=100 \%{ }^{1} . \text { Equilibrium in the gas phase } \\
\text { for the reaction of } \mathrm{Fe}_{3} \mathrm{O}_{4} \text { to } \mathrm{Fe}_{0.945} \mathrm{O}\end{array}$ \\
\hline $1 \mathrm{~b}$ & 800 & 1 & $\begin{array}{l}\zeta_{\mathrm{c} \text { to gas }}=75 \% \text {. Equilibrium in the gas phase for } \\
\text { the reaction of } \mathrm{Fe}_{3} \mathrm{O}_{4} \text { to } \mathrm{Fe}_{0.945} \mathrm{O}\end{array}$ \\
\hline 1_exp & 800 & 1 & Based on experimental data ${ }^{2}$ \\
\hline $2^{-}$ & 920 & 1 & $\begin{array}{l}\zeta_{\mathrm{C} \text { to gas }}=100 \% \text {. Equilibrium in the gas phase } \\
\text { for the reaction of } \mathrm{Fe}_{3} \mathrm{O}_{4} \text { to } \mathrm{Fe}_{0.945} \mathrm{O}\end{array}$ \\
\hline $2 \exp$ & 920 & 1 & Based on experimental data ${ }^{2}$ \\
\hline $3^{--1}$ & 920 & 20 & $\begin{array}{l}\zeta_{\mathrm{C} \text { to gas }}=100 \% \text {. Equilibrium in the gas phase } \\
\text { for the reaction of } \mathrm{Fe}_{3} \mathrm{O}_{4} \text { to } \mathrm{Fe}_{0.945} \mathrm{O}\end{array}$ \\
\hline
\end{tabular}

${ }^{1} \zeta_{\mathrm{C} \text { to gas }}:$ Carbon to gas conversion. Is the molar fraction of carbon from the oil that is converted to gaseous compounds.

${ }^{2}$ The $\zeta_{\mathrm{C} \text { to gas }}$ and gas composition were obtained from experimental measurements, in which the final gas composition after combined oil gasification and iron oxide reduction was measured (Chapter 4). 


\subsection{Process design}

The conceptual design with functional units is developed into a process flow sheet (Figure 7.4). In the process design, the reduction can be recognized in the upper part of the figure. Pyrolysis oil is injected into the reduction reactor, where the oil is gasified and cracked and iron oxide is reduced. The remainder of this reduction gas, which still contains $\mathrm{CO}, \mathrm{H}_{2}, \mathrm{CH}_{4}, \mathrm{C}_{2+}$ and $\mathrm{C}$, is combusted in a furnace with an excess of air. The energy content in the off gas from the furnace is matched to supply the energy required for the gasification/reduction (Heat exchanger 1=HE 1) reaction.

Iron oxide particles from the reduction reactor have to be transferred to the other fluidized bed reactor, where they are oxidized with steam to form the desired hydrogen product. The steam feed for the oxidator is preheated with the off gas from the combustor (HE 2) and with the product gas from the oxidator (HE 3). Both heat exchangers operate in the vapor phase and therefore an evaporator is used to vaporize the water feed before heat exchange is applied. The hydrogen product is purified by condensation of the hydrogen-water mixture and, when the process is operating at 1 bar, compressed to 20 bar.

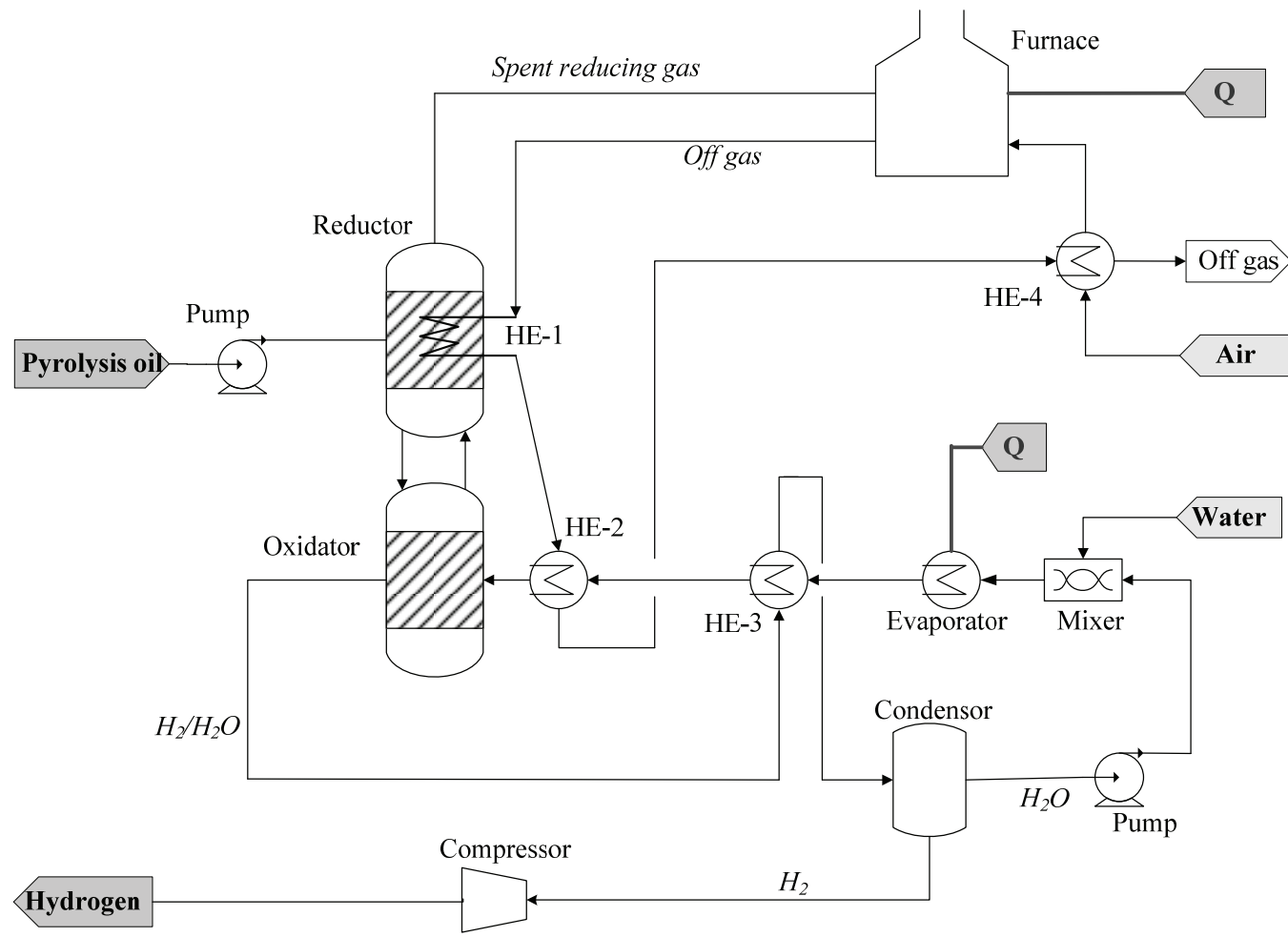

Figure 7.4: Process flow sheet for the steam-iron process with pyrolysis oil feedstock. 


\subsubsection{Process simulation description}

Pyrolysis oil gasification is simulated using a Gibb's reactor in Aspen Plus ${ }^{\mathrm{TM}}$ when equilibrium in the gas phase is assumed. The gas composition and carbon obtained from the gasification is used for the calculation of the reduction of the iron oxide. The equilibrium gas composition after reduction is based on the gas equilibrium ratio of $\mathrm{CO} / \mathrm{CO}_{2}$ and $\mathrm{H}_{2} / \mathrm{H}_{2} \mathrm{O}$ with $\mathrm{Fe}_{3} \mathrm{O}_{4} / \mathrm{Fe}_{0.945} \mathrm{O}$ (Appendix C). It is assumed in all calculations that the reduction of $\mathrm{Fe}_{3} \mathrm{O}_{4}$ to $\mathrm{Fe}_{0.945} \mathrm{O}$ takes place and that $\mathrm{Fe}$ is not formed. In this case the full reduction potential of the pyrolysis oil is used, as the $\mathrm{CO} / \mathrm{CO}_{2}$ and $\mathrm{H}_{2} / \mathrm{H}_{2} \mathrm{O}$ ratios are the lowest for the reduction to wustite. Carbon that is not contributing to the reduction is combusted in the furnace (Table 7.3). For the experimental cases the gas composition measured after oil gasification and iron oxide reduction is used.

The extent of conversion of the iron oxide during reduction determines the amount of hydrogen formed from steam in the oxidation. It is assumed that the oxidation to magnetite is complete and that the equilibrium steam conversion is obtained at the applied oxidation temperature.

\subsubsection{Heat exchange}

\section{Reductor / oxidator}

The energy produced in the exothermic oxidation supplies part of the energy required for the gasification/reduction reactor. This energy produced in the oxidation is transported by the iron oxide particles to the reduction reactor. To do so a temperature gradient over both reactors is established; during reduction a temperature decrease and during oxidation a temperature increase. The temperature change in the reactors depends on the amount of iron oxide circulated per amount of pyrolysis oil injected. The iron oxide to oil mass ratio is assumed to be $60\left(\mathrm{Fe}_{3} \mathrm{O}_{4} / \mathrm{oil}\right)$ and the temperature gradient is calculated using this ratio. The energy exchanged by the solids covers the energy required for the endothermic reduction reactions. However, the energy required for the gasification still needs to be supplied to the reduction reactor. This is done by heat exchange (HE 1) with the off gas obtained from the furnace. Therefore in the energy balances the following relation is used:

Off gas ( sensible heat $)=\mathrm{Q}_{\text {reductor }}+\mathrm{Q}_{\text {oxidator }}$ 
In an ideal fluidized bed no temperature profiles are expected due to the good mixing of the solid particles. The equilibrium conditions are therefore based on the temperature at which the solids are exiting the reactor. Therefore the temperature of the reductor $\left(\mathrm{T}_{\mathrm{red}}\right)$ is lower than the temperature of the oxidator $\left(\mathrm{T}_{\mathrm{ox}}\right)$.

\section{Combustion spent gases}

Energy for the process can be obtained by combustion of the spent gases. This is performed in a furnace in which the off gas can achieve a maximum temperature of $1000{ }^{\circ} \mathrm{C}$. The hot off gas obtained is used for heat exchange with the gasification/reduction reactor (HE 1). The amount of air used in the furnace is adjusted to meet the energy requirement in HE 1 (to fulfill equation 7.2). A surplus of energy in the furnace $\left(\mathrm{Q}_{\text {furnace }}<0\right)$ is obtained when the energy content in the spent gas is more than sufficient to heat the off gas, in which case this energy is used in the evaporator for steam production. There is an energy demand in the furnace if $\mathrm{Q}_{\text {furnace }}>0$, which can be fulfilled by the combustion of additional energy sources, like pyrolysis oil. The off gas is further used to preheat the steam to the required oxidation temperature (HE 2) and for the preheating of the air feed (HE 4) to the furnace.

\section{Steam production}

The required hot steam for the oxidation is preheated by heat exchanging with the product stream of the oxidation reactor (HE 3). The steam input is preheated to the reduction temperature $\left(\mathrm{T}_{\mathrm{red}}\right)$. Due to the exothermic reaction, the iron oxide and gases are heated to the oxidation temperature $\left(\mathrm{T}_{\mathrm{ox}}\right)$ and the final $\mathrm{H}_{2} / \mathrm{H}_{2} \mathrm{O}$ product exits the oxidator at $\mathrm{T}_{\mathrm{ox}}$. The energy content of the $\mathrm{H}_{2} / \mathrm{H}_{2} \mathrm{O}$ stream depends on the hydrogen content and the final oxidation temperature. The evaporator preheats the water and vaporizes the water to steam at $100{ }^{\circ} \mathrm{C}(1 \mathrm{bar})$ and $215^{\circ} \mathrm{C}$ (at 20 bar). The energy required for the evaporation is obtained from the furnace and by hot utilities.

\subsection{Results}

To compare the overall energy efficiency of the different cases, mass and energy balances are created for each case per kilogram of pyrolysis oil. The results will give more insight in the optimal process conditions to maximize the efficiency at which 1 kilogram of pyrolysis oil is converted into the hydrogen product. 


\subsubsection{Mass balances}

The theoretical and experimental gas composition after reduction of the magnetite to wustite with oil is shown in Table 7.3. The equilibrium ratios for the conditions discussed are given in Appendix C. The change in the oxygen content $(\Delta \mathrm{O})$, in the gas phase before and after reduction can be related to the amount of iron oxide reduced and can be used for the calculation of the amount of hydrogen produced in the oxidation (Table 7.3).

Table 7.3: Gas composition of the spent reducing gas after reduction of magnetite to wustite.

\begin{tabular}{|c|c|c|c|c|c|c|}
\hline & Case & & & & & \\
\hline & $1 \mathrm{a}$ & $1 b$ & $1 \_\exp$ & 2 & $2 \_\exp$ & 3 \\
\hline $\mathrm{P}$ (bar) & 1 & 1 & 1 & 1 & 1 & 20 \\
\hline $\mathrm{T}\left(\mathrm{C}^{\mathrm{o}}\right)$ & 800 & 800 & 800 & 920 & 920 & 920 \\
\hline \multicolumn{7}{|l|}{$\begin{array}{l}\text { Component } \\
\text { (Mole/kg oil) }\end{array}$} \\
\hline $\mathrm{CH}_{4}$ & 1.0 & 0.1 & 2.6 & 0.1 & 3.5 & 5.4 \\
\hline $\mathrm{C}_{2}^{+}$ & - & - & 1.0 & - & - & - \\
\hline $\mathrm{CO}$ & 11.4 & 8.9 & 8.1 & 9.5 & 7.3 & 8.0 \\
\hline $\mathrm{H}_{2}$ & 17.3 & 18.1 & 13.2 & 11.0 & 6.7 & 8.4 \\
\hline $\mathrm{CO}_{2}$ & 18.4 & 14.3 & 12.3 & 21.3 & 14.1 & 17.8 \\
\hline $\mathrm{H}_{2} \mathrm{O}$ & 25.9 & 26.9 & 18.9 & 34.0 & 25.7 & 26.3 \\
\hline $\mathrm{C}_{\text {solid }}$ & - & 7.7 & 5.9 & - & 5.9 & - \\
\hline $\begin{array}{l}\text { LHV gas } \\
\text { (MJ/kg oil) }\end{array}$ & 7.4 & 10.0 & 9.2 & 5.4 & 8.8 & 8.6 \\
\hline \multicolumn{7}{|l|}{ Redox } \\
\hline$\Delta \mathrm{O}$ & & & & & & \\
\hline $\begin{array}{l}\text { (Mole/kg oil) } \\
\mathrm{H} \text { product }\end{array}$ & 40.3 & 30.6 & 18.6 & 52.4 & 27.6 & 35.4 \\
\hline$\left(\mathrm{Nm}^{3} / \mathrm{kg}\right.$ dry oil $)$ & 1.35 & 1.02 & 0.62 & 1.75 & 0.92 & 1.18 \\
\hline
\end{tabular}

The reducing potential of the gasified oil at $920{ }^{\circ} \mathrm{C}$ compared to $800{ }^{\circ} \mathrm{C}$ is higher, resulting in more reduced iron oxide (Table 7.3). This results in a lower heating value of the gas obtained after reduction, as more $\mathrm{CO}$ and $\mathrm{H}_{2}$ react with the iron oxide at a high temperature. Increasing the pressure has a similar effect: the reducing potential is slightly lower, resulting in a higher heating value of the spent reducing gas obtained. The hydrogen production based on the experimental data is about half the value of the theoretical hydrogen production. The experimental data is obtained from experiments in which the $\mathrm{Fe}_{3} \mathrm{O}_{4}$ /oil ratio is 60 and equilibrium of the oil with the iron oxide is not obtained, which results in a low hydrogen production. 
Increasing the temperature results, for both the experimental and theoretical case, in an increase of the hydrogen production by almost a factor of 1.5. The amount of steam, which passes through the oxidation reactor without reacting, increases with temperature (Table 7.4). The temperature increase during oxidation is also given in Table 7.4 and the final $\mathrm{H}_{2} / \mathrm{H}_{2} \mathrm{O}$ ratio is based on this calculated temperature.

Table 7.4: Mass balance over the oxidation for the different cases.

\begin{tabular}{lllllll}
\hline & $\begin{array}{l}\text { Cases } \\
\text { la }\end{array}$ & 1b & 1_exp & 2 & 2_exp & 3 \\
\hline $\mathrm{P}($ bar $)$ & 1 & 1 & 1 & 1 & 1 & 20 \\
$\mathrm{~T}_{\text {red }}\left(\mathrm{C}^{\mathbf{0}}\right)$ & 800 & 800 & 800 & 920 & 920 & 920 \\
$\mathrm{~T}_{\text {ox }}\left(\mathrm{C}^{\mathbf{0}}\right)$ & 848 & 838 & 823 & 979 & 961 & 970 \\
\hline Stream $(\mathrm{mol} / \mathrm{kg}$ oil) & 120 & 88 & 50 & 258 & 128 & 169 \\
$\mathrm{H}_{2} \mathrm{O}$, in & 40 & 31 & 19 & 52 & 28 & 35 \\
$\mathrm{H}_{2}$ & 80 & 57 & 32 & 206 & 100 & 133 \\
$\mathrm{H}_{2} \mathrm{O}$, out & & & & & & \\
\hline
\end{tabular}

\subsubsection{Energy balance}

A heat integration study using the data from both the reduction and oxidation was performed to determine the possibilities for heat exchange and to calculate the heat duty for the different process steps for each case. The energy balance for the streams and processes in the redox process are calculated and the energy demand of the processes is given in Table 7.5 .

Table 7.5: Energy requirement of the different process steps $(\mathrm{MJ} / \mathrm{kg}$ oil) in the redox cycle process with pyrolysis oil.

\begin{tabular}{lcllllll}
\hline & $\begin{array}{l}\text { Case } \\
\text { 1a }\end{array}$ & 1b & 1_exp & 2 & 2_exp & 3 & 3_mem \\
& & & & & & & \\
\hline P (bar) & 1 & 1 & 1 & 1 & 1 & 20 & 20 \\
$\mathrm{~T}_{\text {red }}\left({ }^{\circ} \mathrm{C}\right)$ & 800 & 800 & 800 & 920 & 920 & 920 & 920 \\
$\mathrm{~T}_{\text {ox }}\left({ }^{\circ} \mathrm{C}\right)$ & 848 & 838 & 823 & 979 & 955 & 970 & 970 \\
\hline Process step $(\mathrm{MJ} / \mathrm{kg}$ oil) & & & & & & \\
\hline Reductor & 8.4 & 6.9 & 5.4 & 9.9 & 6.5 & 7.7 & 7.7 \\
Oxidator & -2.5 & -2.0 & -1.2 & -3.1 & -1.8 & -2.6 & -2.6 \\
Furnace & -2.1 & -4.9 & -5.5 & 2.3 & -3.9 & -2.9 & -2.8 \\
Evaporator & 4.9 & 3.6 & 2.1 & 10.7 & 5.2 & 6.2 & 1.8 \\
Condenser & -3.3 & -2.3 & -1.3 & -8.5 & -4.0 & -4.7 & - \\
Compressor & 0.66 & 0.50 & 0.30 & 0.83 & 0.50 & - & 0.58 \\
\hline
\end{tabular}


The energy required in the reductor $\left(\mathrm{Q}_{\text {reductor }}\right)$ is supplied by the exothermic oxidation reactor and the off gas from the furnace. The energy requirements for the gasification and reduction can be completely covered with the energy obtained from the combustion of the spent reducing gases and unreacted coke at $800{ }^{\circ} \mathrm{C}\left(\mathrm{Q}_{\text {furnace }}<0\right)$. However, $Q_{\text {furnace }}$ is positive when the reduction is performed at $920{ }^{\circ} \mathrm{C}$ for case 2 , indicating that an additional energy source needs to be supplied to the furnace.

The high energy demand in the reductor is mainly caused by the simultaneous gasification and reduction. Pyrolysis oil consists of a large fraction of water (+/- $30 \mathrm{wt}$ $\%$ ), which is to be evaporated when gasified, resulting in a high energy demand. It would be beneficial to evaporate the pyrolysis oil at a temperature of about $500{ }^{\circ} \mathrm{C}$, before the gasification/reduction. In which case the total energy demand would not change, but only the temperature at which it is required. This would especially be beneficial for the cases performed at $920^{\circ} \mathrm{C}$.

For the cases described here the final off gas temperature (after HE4) is about $70-115^{\circ} \mathrm{C}$ and combined with the large quantities of air, results in a substantial energy loss (2.5-3.6 MJ/kg oil, condensation enthalpy $\mathrm{H}_{2} \mathrm{O}$ not included). The energy required in the evaporator has to be supplied by the surplus of energy in the furnace or externally. The energy demand of the evaporator is at a relatively low temperature and could therefore also be supplied by waste energy streams from close by facilities. The hydrogen product is separated from the steam fraction by condensation in the condenser, resulting in a substantial energy loss $\left(\mathrm{Q}_{\text {condenser }}\right)$, as the condensation enthalpy cannot be recovered. It can be clearly seen that the loss of energy in the condenser is increasing with increasing oxidation temperature. Therefore an additional case ( 3 mem) is discussed in the next section, in which the separation of the $\mathrm{H}_{2} / \mathrm{H}_{2} \mathrm{O}$ mixture is performed using membranes.

In case 3, the energy required to pump water to a pressure of $20 \mathrm{bar}(4 \mathrm{~kJ} / \mathrm{kg}$ oil feed) or to pump pyrolysis oil to $20 \mathrm{bar}(6 \mathrm{~kJ} / \mathrm{kg}$ oil) is small and negligible compared to the other energy streams shown.

Discussion of the energy balance of the different cases

\section{Case 1a, 1b and 1_exp}

The heat provided by the combustion of the spent reaction gases can supply the heat required for gasifying the pyrolysis oil and evaporating the steam for the oxidation in case $1 \mathrm{~b}$ and 1_exp. In both cases not the full potential of oil for the 
reduction was used, which resulted in a sufficient heating value of the spent gas to supply the energy for both the reductor and evaporator. In case 1a on the other hand this was not the case and additional energy was required in the evaporator.

\section{Case 2 and 2_exp}

The hydrogen production for case 2 is high, but results in a high energy demand in the reductor and evaporator. Furthermore the temperature increase in the oxidator is high $\left(59^{\circ} \mathrm{C}\right)$, caused by the relatively high conversion of the iron oxide. Both effects result in an overall high energy demand, mostly needed for the evaporation of the water feed. At temperatures above $900{ }^{\circ} \mathrm{C}$, the unfavorable $\mathrm{H}_{2} / \mathrm{H}_{2} \mathrm{O}$ equilibrium in the oxidation is a bottleneck for energy efficient processing. When the process is operated at 20 bar however, it is also possible to separate the hydrogen product by membrane modules, lowering the energy required as condensation can be prevented in this situation (see case 3_mem). Another option is to use the product obtained from the oxidation reactor in a PEM fuel cell. In such a fuel cell a feed consisting of a molar $\mathrm{H}_{2} \mathrm{O} / \mathrm{H}_{2}$ ratio of 2 is required, as the protons migrate as $\mathrm{H}_{3} \mathrm{O}^{+}$ ions through the membrane. The complete separation of hydrogen from the product gas is in this case not necessary. The obtained $\mathrm{H}_{2} / \mathrm{H}_{2} \mathrm{O}$ (gas phase) product could then directly be supplied to a fuel cell for electricity production on site.

\section{Case 3 and 3 mem}

Case 3 is similar to case 2, but due to the enhanced pressure the reduction potential of the oil is decreased. Therefore the heating value of the spent gases is sufficient to supply the energy for the reductor. It is possible to use $\mathrm{Pd} / \mathrm{Ag}$ membrane modules for the separation of steam from the steam/hydrogen product [7-9], when the process is operating at 20 bar. To separate hydrogen from water at temperatures between 400 and $500{ }^{\circ} \mathrm{C}$ permeation fluxes up to $8 \mathrm{~m}^{3} / \mathrm{m}^{2} \mathrm{~h}$ can be achieved [8]. This results in membrane modules of $0.098 \mathrm{~m}^{2} \mathrm{~h} / \mathrm{kg}$ oil when a flux of $0.8 \mathrm{Nm}^{3} \mathrm{H}_{2} / \mathrm{kg}$ oil needs to be achieved (case $3 \_$mem). The main advantage of this separation is that only an equal molar amount of water, compared to hydrogen product, has to be evaporated to steam. The hydrogen product will in this case be delivered at a pressures between 1 and 2 bar $[8,9]$, which results in an extra compressor duty. In the calculations it was assumed that the membrane separation takes place at $400{ }^{\circ} \mathrm{C}$. 


\subsubsection{Combined mass and energy balances}

The overall heat requirement for the process $(\mathrm{Q}>0)$ for all cases is the amount of energy required in the furnace plus the amount of energy required in the evaporator:

$\mathrm{Q}=\mathrm{Q}_{\text {furnace }}+\mathrm{Q}_{\text {evaporator }}$

Only the energy requirements are taken into account in the overall hydrogen efficiency calculation. The overall balances for all cases are summarized in Table 7.6. With the combined mass and energy balances, overall process efficiencies could be determined (using equation 7.1). The found efficiencies are lower or in the same range compared to typical hydrogen from biomass process efficiencies, which are in the LHV/LHV values between 50 and $58 \%$ [2].

Table 7.6: Process efficiencies of the different cases.

\begin{tabular}{|c|c|c|c|c|c|c|c|c|}
\hline & \multicolumn{7}{|c|}{ Cases } \\
\hline & & $1 \mathrm{a}$ & $1 b$ & $1 \_\exp$ & 2 & $2 \exp$ & 3 & 3 mem \\
\hline $\mathrm{H}_{2}$ production & $\mathrm{Nm} 3 / \mathrm{kg}$ dry oil & 1.35 & 1.02 & 0.62 & 1.75 & 0.92 & 1.18 & 1.18 \\
\hline Q & $\mathrm{MJ} / \mathrm{kg}$ oil & 2.8 & - & - & 13.0 & 1.3 & 3.3 & - \\
\hline $\mathrm{W}_{\text {comp }}$ & $\mathrm{MJ} / \mathrm{kg}$ oil & 0.66 & 0.50 & 0.30 & 0.85 & 0.45 & - & 0.56 \\
\hline $\begin{array}{l}\eta \text { process } \\
\text { (LHV/LHV) }\end{array}$ & & 0.53 & 0.47 & 0.29 & 0.46 & 0.39 & 0.48 & 0.54 \\
\hline
\end{tabular}

An increased temperature has a negative influence on the overall process efficiency from a theoretic point of view (compare case 1a and 2). More hydrogen per $\mathrm{kg}$ oil is produced at $920^{\circ} \mathrm{C}$, but a lot of energy is wasted in the oxidation, resulting in a high energy demand of the process.

When it is assumed that not the full reduction potential of the oil can be used, due to incomplete conversion of oil to the gas phase (case $1 \mathrm{~b}$ ) at $800{ }^{\circ} \mathrm{C}$, the overall efficiency decreases. However the efficiency is still comparable to the efficiency obtained at high temperature. Thus when equilibrium can be obtained in the gas phase a low temperature is preferred to a high temperature, even when a substantial amount of the oil ( $25 \%$ of the carbon input) is not participating in the reduction reactions. In fact a surplus of energy was produced $(1.3 \mathrm{MJ} / \mathrm{kg}$ oil) in case $1 \mathrm{~b}$, which was not needed in the process.

An increased pressure at high temperatures results in an improved efficiency, 
which can be further improved when separation of $\mathrm{H}_{2}$ from $\mathrm{H}_{2} \mathrm{O}$ is performed by using a membrane. The efficiency in this case is similar to commercial biomass to hydrogen production processes with an extra energy production of $1 \mathrm{MJ} / \mathrm{kg}$ oil obtained from the furnace.

For the experimental cases the opposite is true; a high temperature (case 2_exp) is preferential to a low temperature (case 1_exp). This is caused by the low hydrogen production at low temperatures. Apparently the gasification/reduction reactions are not sufficient at this temperature, resulting in a low conversion in the reductor. The conversion of oil to pure hydrogen can be improved (based on experimental data) by increasing the $\mathrm{Fe}_{3} \mathrm{O}_{4} /$ oil ratio (Chapter 3 and 4).

\subsection{Conclusions}

The overall energy efficiency for the production of pure hydrogen using the pyrolysis oil driven steam-iron process is evaluated for different process conditions. The used process consists of a two-step process from which relatively pure renewable hydrogen can be obtained, without the need of any purification steps. An energy efficiency (LHV based) of $53 \%$ is achieved when the equilibrium conversion is reached in the redox cycle with pyrolysis oil at $800{ }^{\circ} \mathrm{C}$, which is similar to other thermo-chemical biomass to hydrogen routes (50-58\%). The use of pyrolysis oil in the steam-iron process for the production of hydrogen is energy efficient, based on equilibrium calculations. However experimental results showed that this theoretical efficiency could not be achieved. Possible improvements to increase the efficiency are: I) improving the iron oxide material to increase the conversion during reduction at $800{ }^{\circ} \mathrm{C}$ or by II) using membranes for the separation of steam from the hydrogen product at high process temperatures $\left(>900^{\circ} \mathrm{C}\right)$.

\subsection{Literature}

1 Spath PL, Mann MK, Amos WA, NREL/MP-510-33112, National Renewable Energy Laboratory, Golden, CO., 2000

2 Hamelinck CN, Faaij APC, J. of Power Sources 111 (2002) p. 1-22.

3 Cheng X, et al., J. of Power Sources 165 (2007) p. 739-756.

$4 \quad$ Chilukuri P, et al.,Ind. \& Eng. Chem. Res., 46 (2007) p. 8701-8709.

5 Kersten SRA, et al., Ind. \& Eng. Chem. Res. 42 (2003) p. 6755-6764.

6 Gasior SJ, Bureau of Mines, Washington, 1961. 
7 Smith B, Shantha MS. Int. J. of Chem. Reactor Eng. 5 (2007) A84.

8 Sjardin M, Damen KJ, Faaij APC, Energy, 31 (2006) p. 2523-2555.

9 Hou K, Hughes R., J. of Membrane. Science., 214 (2003) p. 43-55.

10 Phyllis, Database for biomass and waste, www.ecn.nl/phyllis, Energy research Centre of the Netherlands.

11 Yanga C, Ogdena J., Int. J. of Hydrogen Energy, 32 (2007) p. 268-286. 


\section{Appendices}




\section{Appendix A}

\section{Particle models}

\section{Homogeneous model}

The homogeneous model can be applied in situations where the rate of diffusion of the reactant gas through the porous structure is fast, in which case the reactant gas will penetrate into the solid and react throughout the particle. It is possible in this model to take into account diffusion effects within the particle, which results in a conversion gradient within the particle. The diffusion in the particle, which is equal to the amount of reactant (in this case $\mathrm{H}_{2}$ ) reacting with the iron oxide, can be described as follows:

$\mathrm{D}_{\mathrm{R}}\left(\frac{\mathrm{d}^{2} \mathrm{C}_{\mathrm{H}_{2}}}{\mathrm{dR}^{2}}+\frac{2}{\mathrm{R}_{\mathrm{p}}} \frac{\mathrm{dC}_{\mathrm{H}_{2}}}{\mathrm{dR}}\right)=\mathrm{k}_{\mathrm{v}} \mathrm{C}_{\mathrm{H}_{2}}^{\mathrm{m}} \mathrm{C}_{\text {iron }}^{\mathrm{n}}$

The amount of iron oxide reacting can be described as:

$$
-\frac{\mathrm{dC}_{\text {iron }}}{\mathrm{dt}}=\mathrm{k}_{\mathrm{v}} \mathrm{C}_{\mathrm{H}_{2}}^{\mathrm{m}} \mathrm{C}_{\text {iron }}^{\mathrm{n}}
$$

The order of the reaction for the reactant gas hydrogen in the reduction of iron oxide is set at 1 as reported in literature [1-3]. In the case where adsorption of the gas phase on the surface plays a role, this value can be expected to be between 0 and 1 . The order of the solid phase in this reaction is expected to be $0,2 / 3$ or 1 , but in most gas-solid reactions the order of the solid phase is 0 [4]. The homogeneous model can be classified in three different regimes depending on the concentration gradient of the gas reactant in the particle. The regime depends on the Thiele modulus $(\varphi)$, which represents the ratio of the reaction rate constant and the diffusion coefficient in the particle. 
$\varphi=\left(\frac{\mathrm{k}_{\mathrm{v}} \mathrm{C}_{\mathrm{H}_{2}}^{\mathrm{m}-1} \mathrm{C}_{\text {iron }}^{\mathrm{n}} \mathrm{R}_{\mathrm{p}}^{2}}{\mathrm{D}_{\mathrm{R}}}\right)^{1 / 2}$

For values $\Phi>3$ the reaction rate is relatively high and therefore part of the gaseous reactant is converted before reaching the centre of the particle. For very high values of $\Phi$ the model approaches a shrinking core model, which means the reaction takes place at a sharp interface between reacted and unreacted solid. For values between $0.2<\Phi<3$ a concentration profile of the gaseous reactant is expected. For values $\Phi<0.2$ the concentration of the gaseous reactant is uniform throughout the particle and the particle model in this case is also referred to as the pseudo homogenous model [4].

\section{Pseudo homogeneous model}

In this simplified form of the homogeneous model it is assumed that there are no concentration and temperature gradients in and outside the solid particle. Due to the mentioned simplifications it is in most cases not a good representation of the physical conversion of the solid particle. Limitations due to mass transport or physical changes of the solid, like porosity, cannot be introduced in the model. The model can therefore only be applied when the changes of the solid properties during reaction are minimal and that the rate controlling step is the chemical reaction itself. In the pseudo homogeneous model the reaction rate can be described by equation A.2 [4] and thus the conversion of the particle with time is:

$$
\begin{aligned}
& \alpha=1-\mathrm{e}^{-\mathrm{k}_{\mathrm{V}} \mathrm{C}_{\mathrm{H}_{2}}^{\mathrm{m}} \mathrm{t}} \quad \text { if } \mathrm{n}=1 \\
& \text { and } \quad \alpha=\mathrm{k}_{\mathrm{v}} \mathrm{C}_{\mathrm{H}_{2}}^{\mathrm{m}} \mathrm{t} \quad \text { if } \mathrm{n}=0
\end{aligned}
$$

Figure A.1 shows the relative conversion versus time and the relative conversion rate versus relative conversion. Tau represents the time to obtain a relative conversion of 0.98 . 

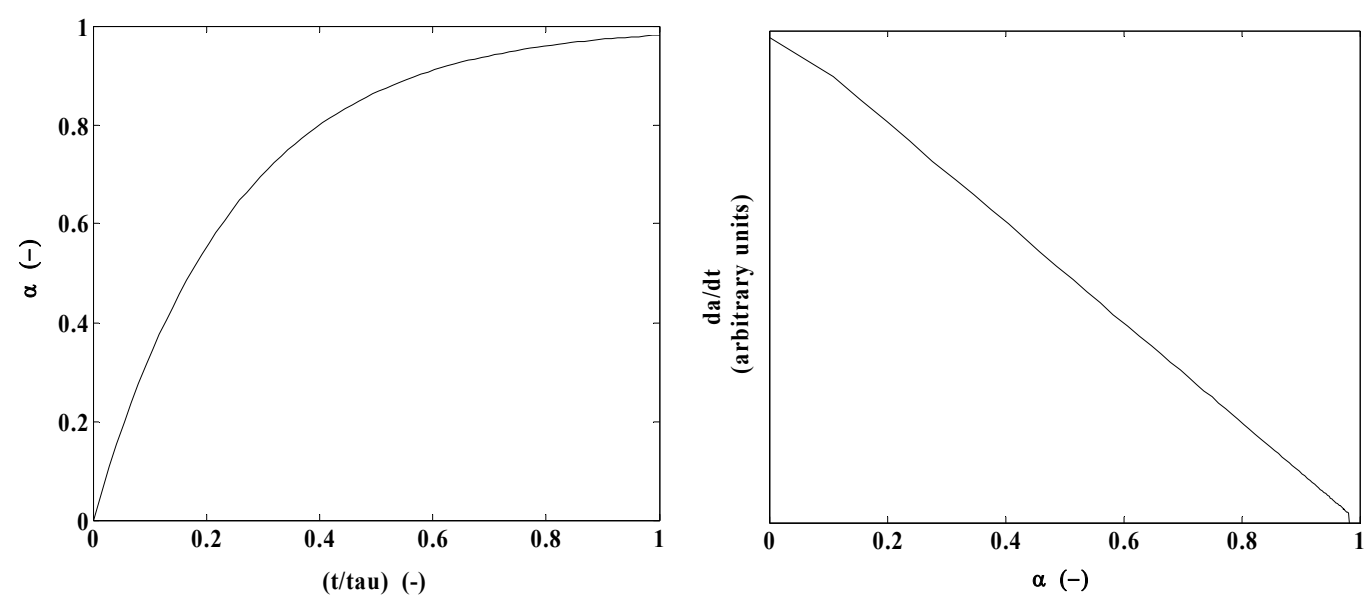

Figure A.1: Relative conversion-time relation (left) and the relative conversion rate-relative conversion (right) for the pseudo homogeneous model $(n=1)$.

\section{Shrinking core model}

The shrinking core model (SCM) is a popular model to describe gas-solid reactions. It assumes that the particle is a non-porous solid and that the reaction is solely taking place at the phase boundary of the unreacted solid and the product layer. Initially the solid particle consists of unreacted solid and the reaction can take place without any diffusion limitations. When the reaction continues a product layer is formed at the boundary of the particle and reaction can only take place when the gas diffuses to the phase boundary of the unreacted solid.

In the SCM described here it is assumed that a porous product layer is formed upon reaction. However in the reduction of iron oxide a gas impermeable dense iron (oxide) layer $\left(\mathrm{Fe}_{1-\mathrm{y}} \mathrm{O}\right.$ or $\left.\mathrm{Fe}\right)$ can be formed. In the case of the formation of a dense wustite phase, the reduction is continued via the formation of ions at the surface of the particle and inward moving ions $\left(\mathrm{Fe}^{2+/} \mathrm{Fe}^{3+}\right)$ have to diffuse through the product layer. This solid state diffusion has been found to control, under certain conditions, the overall rate of the reduction of metal oxides and the oxidation of metal [5]. In this case the flux of iron ions can be described with a similar relation as the diffusion of the reactant gas, however the diffusion resistance is of magnitudes smaller, as solid state diffusion usually is a slow process.

In the simplest form, described here, it is assumed that the particle has a spherical shape, the product obtained upon reaction is porous, no temperature differences (isothermal) exist in the particle and the volume of the particle does not 
change during reaction. Extended models incorporating different particle geometries, volume change etc. are described in [5]. When the diffusion through the product layer is a pseudo-steady process the overall reaction rate (incorporating the mass transfer through the gas film) can be described as follows [4]:

$$
\mathrm{J}_{\mathrm{H}_{2}}=4 \pi \mathrm{R}_{0}^{2}\left(\mathrm{C}_{\mathrm{H}_{2}, 0}-\frac{\mathrm{C}_{\mathrm{H}_{2} \mathrm{O}, 0}}{\mathrm{~K}_{\mathrm{e}}}\right)\left(\frac{1}{\frac{1}{\mathrm{k}_{\mathrm{g}}}\left(1+\frac{1}{\mathrm{~K}_{\mathrm{e}}}\right)+\frac{\left(\mathrm{R}_{0}-\mathrm{R}_{\mathrm{i}}\right)}{\left(\mathrm{R}_{\mathrm{i}} / \mathrm{R}_{0}\right) \mathrm{D}_{\text {eff }}}\left(1+\frac{1}{\mathrm{~K}_{\mathrm{e}}}\right)+\frac{1}{\left(\mathrm{R}_{\mathrm{i}} / \mathrm{R}_{0}\right)^{2} \mathrm{k}_{\mathrm{s}}}}\right)
$$

In this equation it is assumed that the diffusion coefficients and the mass transfer coefficient are equal for $\mathrm{H}_{2}$ and $\mathrm{H}_{2} \mathrm{O}$. The rate of reaction of the gas constant depends on the amount of unreacted solid present in the particle, which is related to the unreacted particle core radius $\left(\mathrm{R}_{\mathrm{i}}\right)$. The change of the unreacted core radius can be found by solving the equation in which the mole balance of $\mathrm{H}_{2}$ is equal to the mole balance of the particle:

$$
4 \pi \mathrm{R}_{\mathrm{i}}{ }^{2} \mathrm{c}_{\text {iron, }, 0} \frac{\mathrm{dR}_{\mathrm{i}}}{\mathrm{dt}}=-\mathrm{J}_{\mathrm{H}_{2}}
$$

The conversion of the particle is defined by the unreacted core and the initial size of the particle:

$$
\alpha=1-\left(\frac{\mathrm{R}_{\mathrm{i}}}{\mathrm{R}_{0}}\right)^{3}
$$

Solving A.5 will result in a conversion-time relation in which all processes contribute in the overall reaction rate. However, in practice, it may occur that one of the processes is rate determining, resulting in simpler relations for the conversion time: 
Mass transfer through the gas film limited:

$\alpha=\frac{3 \mathrm{k}_{\mathrm{g}}}{\mathrm{C}_{\text {iron }, 0} \mathrm{R}_{0}}\left(\frac{\mathrm{K}_{\mathrm{e}}}{1+\mathrm{K}_{\mathrm{e}}}\right)\left(\mathrm{C}_{\mathrm{H}_{2}, 0}-\frac{\mathrm{C}_{\mathrm{H}_{2} \mathrm{O}, 0}}{\mathrm{~K}_{\mathrm{e}}}\right) \mathrm{t}$

Diffusion through the ash layer limited:

$1-3(1-\alpha)^{2 / 3}+2(1-\alpha)=\frac{6 \mathrm{D}_{\text {eff }}}{\mathrm{R}_{0}{ }^{2} \mathrm{C}_{\text {iron }, 0}}\left(\frac{\mathrm{K}_{\mathrm{e}}}{1+\mathrm{K}_{\mathrm{e}}}\right)\left(\mathrm{C}_{\mathrm{H}_{2}, 0}-\frac{\mathrm{C}_{\mathrm{H}_{2} \mathrm{O}, 0}}{\mathrm{~K}_{\mathrm{e}}}\right) \mathrm{t}$

Chemical reaction limited:

$1-(1-\alpha)^{1 / 3}=\frac{\mathrm{k}_{\mathrm{s}}}{\mathrm{C}_{\text {iron, } 0} \mathrm{R}_{0}}\left(\mathrm{C}_{\mathrm{H}_{2}, 0}-\frac{\mathrm{C}_{\mathrm{H}_{2} \mathrm{O}, 0}}{\mathrm{~K}_{\mathrm{e}}}\right) \mathrm{t}$

The relative conversion - time relation for all three cases is given in Figure A.2

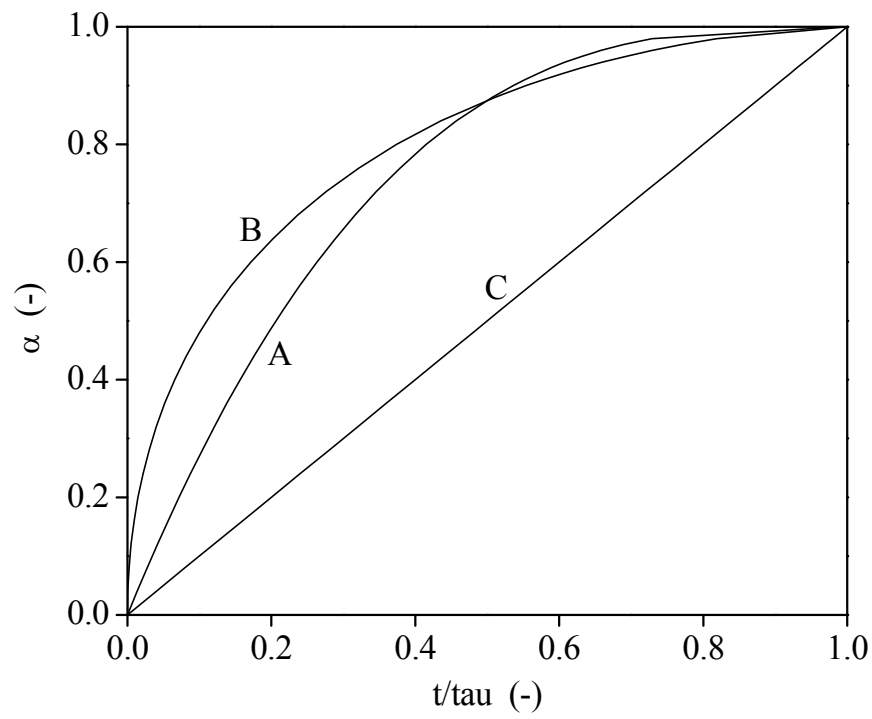




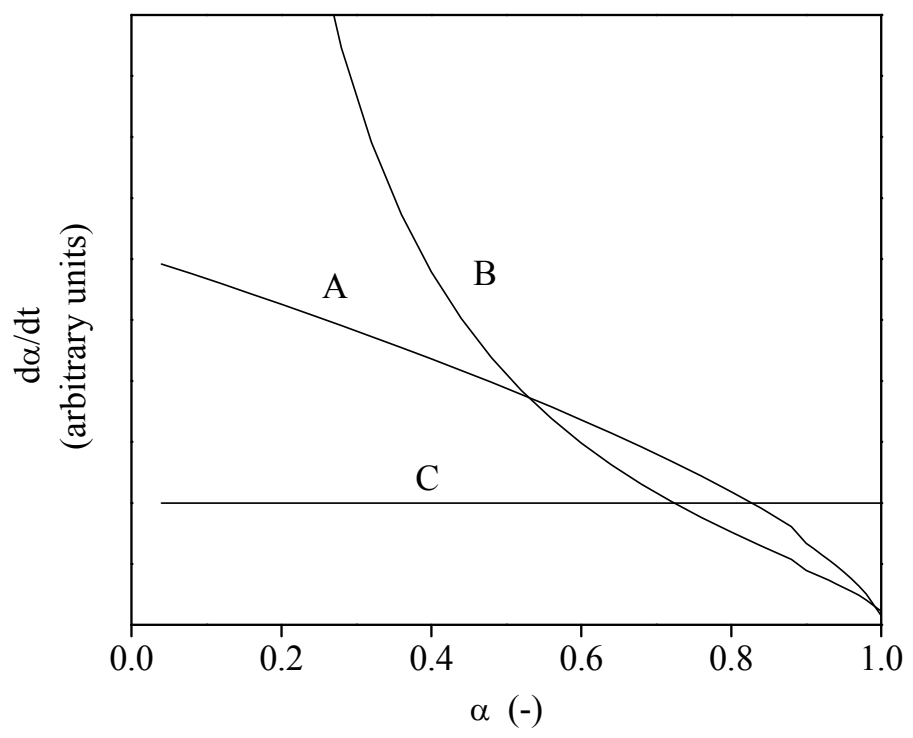

Figure A.2: The conversion/time relation and the relative conversion rate/relative conversion relation obtained from the shrinking core model for the three different limiting cases.

A: Limited by the chemical reaction

B: Limited by diffusion through the ash layer

C: Limited by mass transfer through the gas film

Figure A.2 shows that the relative conversion/time relation gives a minor difference between the ash layer diffusion limitation and the core reaction limitation. Therefore the relative conversion rate given for different relative conversions (Figure A.2) of the particle is calculated, which gives a more distinct difference between the two limiting cases. When ash layer diffusion is limiting a convex shape of the curve is observed., while a concave shape is expected when the core reaction is limiting the overall reaction rate.

\section{Grainy pellet model}

This model is used for porous solid particles. In this model the particle is represented as a large collection of grains. The reaction takes place in the grain following the shrinking core model. Diffusion of the gas can take place along the small grains to the reaction site and therefore in this model the reaction surface is enhanced compared to the shrinking core model [4-6]. In the model described here similar assumptions are used for the grain as previously described in the shrinking core model. Furthermore it is assumed that the particle has a spherical geometry and 
the volume of the particle does not change.

In this model it is assumed that the diffusion of the gaseous reactant from the surface of the particle to the grains is equal to the reaction rate of the gaseous reactant in a grain multiplied by the number of grains present in the particle:

$$
\mathrm{J}_{\mathrm{H}_{2} \text {, grain }} \mathrm{N}_{\text {grain }}=\mathrm{D}_{\mathrm{R}}\left(\frac{\mathrm{d}^{2} \mathrm{C}_{\mathrm{H}_{2}}}{\mathrm{dR}^{2}}+\frac{2}{\mathrm{R}} \frac{\mathrm{dC}_{\mathrm{H}_{2}}}{\mathrm{dR}}\right) \text {, with } \mathrm{N}_{\text {grain }}=\frac{3 \mathrm{f}_{\mathrm{s}}}{4 \pi \mathrm{r}_{\mathrm{g} 0}}
$$

It is assumed that all grains have the same size and spherical geometry. The reaction rate for the gas phase in a particle according to the shrinking core model is given by equation A.5 and can be used in the grainy pellet model for the grains in the particle if the mass transfer through the gas film is excluded. This results in:

$$
\mathrm{D}_{\mathrm{R}}\left(\frac{\mathrm{d}^{2} \mathrm{C}_{\mathrm{H}_{2}}}{\mathrm{dR}^{2}}+\frac{2}{\mathrm{R}} \frac{\mathrm{dC}_{\mathrm{H}_{2}}}{\mathrm{dR}}\right)=\frac{3 \mathrm{f}_{\mathrm{s}} \frac{\mathrm{k}_{\mathrm{s}}}{\mathrm{r}_{\mathrm{g} 0}\left(\frac{\mathrm{r}_{\mathrm{gi}}}{\mathrm{r}_{\mathrm{g} 0}}\right)^{2}\left(\mathrm{C}_{\mathrm{H}_{2}}-\frac{\mathrm{C}_{\mathrm{H}_{2} \mathrm{O}}}{\mathrm{K}_{\mathrm{e}}}\right)}}{1+\frac{\mathrm{r}_{\mathrm{gi}} \mathrm{k}_{\mathrm{s}}}{\mathrm{D}_{\mathrm{R}}}\left(1+\frac{1}{\mathrm{~K}_{\mathrm{e}}}\right)\left(1-\frac{\mathrm{r}_{\mathrm{gi}}}{\mathrm{r}_{\mathrm{g} 0}}\right)}
$$

If there is a resistance for mass transfer in the gas film surrounding the particle, the boundary conditions for this equation are:

at the surface of the particle:

$$
\mathrm{R}=\mathrm{R}_{\mathrm{p}} \quad \mathrm{D}_{\mathrm{R}} \frac{\mathrm{dC}_{\mathrm{H}_{2}}}{\mathrm{dR}}=\mathrm{k}_{\mathrm{g}}\left(\mathrm{C}_{\mathrm{H}_{2,0}}-\mathrm{C}_{\mathrm{H}_{2}}\right)
$$

and in the centre of the particle:

$$
\mathrm{R}=0 \quad \frac{\mathrm{dC}_{\mathrm{H}_{2}}}{\mathrm{dR}}=0
$$

The conversion rate of the grain depends on the concentration of the gaseous reactant at the surface of the grain. The stoichiometric balance for a single grain is equal to the amount of gas reacting: 


$$
-\frac{\mathrm{dr}_{\mathrm{gi}}}{\mathrm{dt}}=\frac{\mathrm{k}_{\mathrm{s}}\left(\mathrm{C}_{\mathrm{H}_{2}}-\frac{\mathrm{C}_{\mathrm{H}_{2} \mathrm{O}}}{\mathrm{K}_{\mathrm{e}}}\right)}{\frac{\rho_{\text {iron }}}{\mathrm{M}_{\text {iron }}}\left[1+\frac{\mathrm{r}_{\mathrm{gi}} \mathrm{k}_{\mathrm{s}}}{\mathrm{D}_{\text {eff }}}\left(1+\frac{1}{\mathrm{~K}_{\mathrm{e}}}\right)\left(1-\frac{\mathrm{r}_{\mathrm{gi}}}{\mathrm{r}_{\mathrm{g} 0}}\right)\right]}
$$

The relative conversion of the grain is defined as:

$$
\alpha_{\mathrm{g}}=1-\left(\frac{\mathrm{r}_{\mathrm{gi}}}{\mathrm{r}_{\mathrm{g} 0}}\right)^{3}
$$

The conversion rate of a grain depends on the amount of fresh material present in the grain and the gas concentration at the surface of the grain. The conversion of a grain can therefore depend on the location in the particle if a concentration gradient exists in the particle. The overall relative conversion of the particle $(\alpha)$ is the sum of the conversion of the individual grains located on different radii in the particle $\left(\alpha_{g}\right.$ $(\mathrm{R}))$ :

$$
1-\alpha=\frac{\int_{0}^{R_{p}}\left(1-\alpha_{g}(R)\right) R^{2} d R}{\int_{0}^{R_{p}} R^{2} d R}=\frac{3}{R_{p}^{3}} \int_{0}^{R_{p}}\left(1-\alpha_{g}(R)\right) R^{2} d R
$$

A numerical descretization method was used to solve equation A.11 and A.12 in MATLAB. More simple solutions can be obtained when only one mechanism is limiting the overall reaction rate. Some of these limiting cases correspond with the limiting cases obtained in the shrinking core model, with the difference that the grain size instead of the particle size should be adopted. For example if the chemical reaction in the grain is limiting the overall reaction rate, the conversion can be described as: 
$1-(1-\alpha)^{1 / 3}=\frac{\mathrm{M}_{\mathrm{s}}\left(\mathrm{C}_{\mathrm{H}_{2}}-\frac{\mathrm{C}_{\mathrm{H}_{2} \mathrm{O}}}{\mathrm{K}_{\mathrm{e}}}\right) \mathrm{k}_{\mathrm{s}} \mathrm{t}}{\rho_{\mathrm{s}} \mathrm{r}_{\mathrm{g} 0}}$

When the diffusion in between the grains is limiting the reaction the conversion-time relation becomes [7]:

$1-(1-\alpha)^{1 / 3}+\sigma_{\mathrm{p}}^{2}\left[1-3(1-\alpha)^{2 / 3}+2(1-\alpha)\right]=\frac{\mathrm{k}_{\mathrm{s}}}{\mathrm{R}_{0} \mathrm{C}_{\mathrm{B}, 0}}\left(\mathrm{C}_{\mathrm{H}_{2}, 0}-\frac{\mathrm{C}_{\mathrm{H}_{2} \mathrm{O}, 0}}{\mathrm{~K}_{\mathrm{e}}}\right)\left(1+\sigma_{\mathrm{p}}^{2}\right) \mathrm{t}$,

with $\sigma_{\mathrm{p}}=\left(\frac{\mathrm{f}_{\mathrm{s}} \mathrm{k}_{\mathrm{s}} \mathrm{R}_{0}}{6 \mathrm{D}_{\mathrm{R}}}\right)^{1 / 2}$

This equation is similar to the limiting case where ash diffusion controls the reaction rate in the shrinking core model (A.8). The difference is mainly due to the correction factor $\sigma_{\mathrm{p}}$, which represents a Thiele modulus for the structure in the particle. Higher values of $\sigma_{\mathrm{p}}$, indicates more influence of the diffusion in the particle to the grains.

When inter grain diffusion is limiting, the relative conversion rate versus conversion will show the trend as in Figure A.3, which gives a similar trend compared to ash layer diffusion limitation in the SCM. Figure A.3 shows the relative conversion rate when mass transport from the bulk to the particle is limiting the overall reaction rate. As expected the conversion rate is constant until the reaction is near completion.
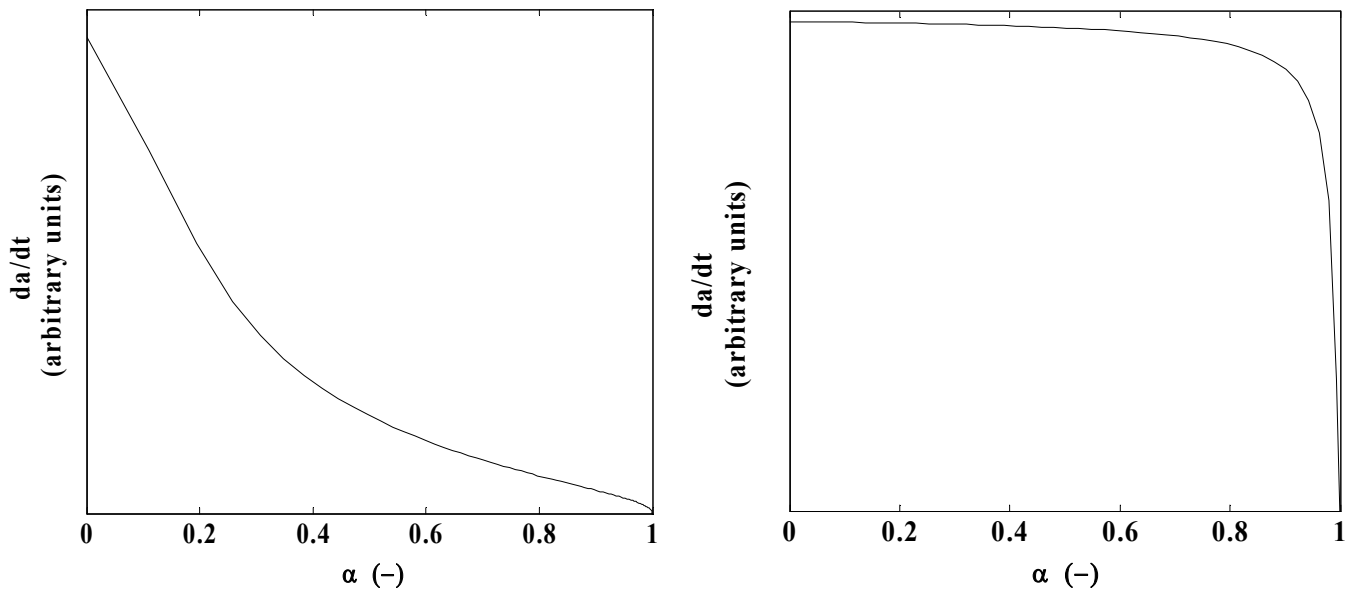

Figure A.3: Limiting cases of the GPM model. Left figure shows the inter grain diffusion limitation and right figure shows the limitation of mass transport from the bulk to the surface. 


\section{Crackling Core model}

Both the SCM and GPM describe a reaction in which the reactant surface (core surface in these models) decreases with progressive reaction. The crackling core model $(\mathrm{CCM})$, on the other hand, can describe a reaction in which the particle becomes more porous upon reaction and therefore increases the number of available reaction sites. The CCM is based on both the SCM and GPM to describe the timeconversion relation, with the difference that the grains are being formed upon reaction. The structural changes taking place in the particle can be caused by a chemical or physical change of the solid material.

In the CCM the solid is regarded as a non-porous solid, which under reaction with a gas (from the outside in) turns into a porous grainy material (crackling step). The formed grains than react according to a SCM to form the final product. For the two step reduction of iron oxide $\left(\mathrm{Fe}_{3} \mathrm{O}_{4}-\mathrm{Fe}_{1-\mathrm{y}} \mathrm{O}-\mathrm{Fe}\right), \mathrm{Fe}_{1-\mathrm{y}} \mathrm{O}$ can be seen in the $\mathrm{CCM}$ as an intermediate product.

The relative conversion rate versus the relative conversion of the particle is calculated using the relations given in [8] in the case when the core reaction in the grain is limiting (Figure A.4). The total time for reaction to be completed is:

$$
\tau=\tau_{\mathrm{g}}+\tau_{\mathrm{c}}, \text { with } \omega=\frac{\tau_{\mathrm{c}}}{\tau}
$$

In which $\tau_{\mathrm{c}}$ and $\tau_{\mathrm{g}}$ are the time for the crackling and grain reaction to be finished. Two cases are calculated in Figure A.4: A $\omega==0.1$ and thus $\tau_{\mathrm{c}}<\tau_{\mathrm{g}}$ and in B $\omega=0.9$ and thus $\tau_{\mathrm{c}}>\tau_{\mathrm{g}} . \alpha_{\mathrm{i}}$ is the conversion at which the crackling reaction is finished and is set on 0.3 (conversion to wustite) in the calculation. 

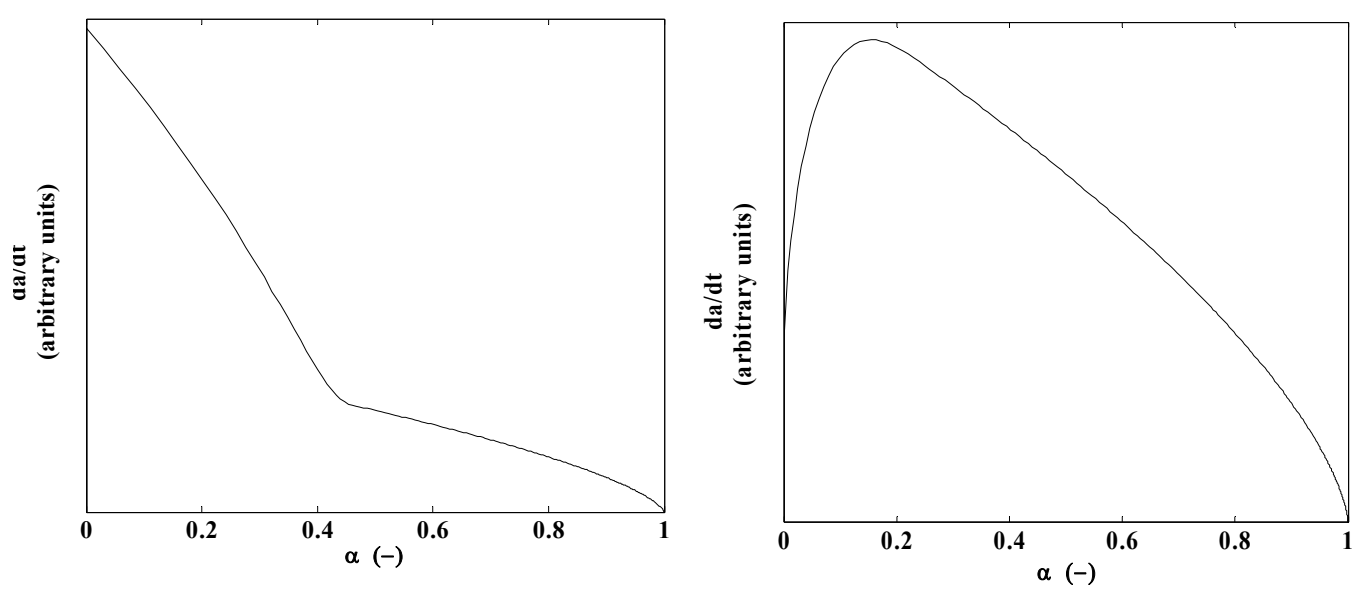

Figure A.4: The conversion rate for different relative conversion using the CCM model and assuming reaction control in the grains. $A: \omega=0.1, \alpha_{i}=0.3$. $B: \omega=0.9, \alpha_{i}=0.3$. 


\section{Appendix B}

\section{Mass and heat transfer effects}

To avoid intra and inter particle mass transfer effects the set-up should be build in such a way that these factors do not play a role in the overall reaction rate, which will be verified in this appendix for conditions applied in the TPR and isothermal reduction method.

\section{Theoretical verification}

The absence of external diffusion can be checked by the following condition [9] :

$\frac{\mathrm{J}_{\mathrm{H}_{2}} \mathrm{~d}_{\mathrm{p}}}{2 \mathrm{~V}_{\text {sample }} \mathrm{k}_{\mathrm{g}} \mathrm{C}_{\mathrm{H} 2}}<0.15$

The external diffusion coefficient $\left(\mathrm{k}_{\mathrm{g}}\right)$ is derived from:

$$
\mathrm{Sh}_{\mathrm{p}}=\frac{\mathrm{k}_{\mathrm{g}} \mathrm{d}_{\mathrm{p}}}{\mathrm{D}_{\mathrm{g}}}=2+\frac{0.81}{\sqrt{\varepsilon}} \operatorname{Re}_{\mathrm{p}}^{0.5} \mathrm{Sc}^{1 / 3}
$$

The absence of internal diffusion is checked with [1]:

$$
\frac{\left(\mathrm{d}_{\mathrm{p}} / 6\right)^{2}}{\mathrm{C}_{\mathrm{H} 2} \mathrm{D}_{\text {eff }}} \frac{\mathrm{J}_{\mathrm{H}_{2}}}{(1-\varepsilon) \mathrm{V}_{\text {sample }}}<0.03-0.7 \text {, with } \mathrm{D}_{\text {eff }}=\mathrm{D}_{\text {gas }} \frac{\varepsilon_{\mathrm{p}}}{\tau_{\mathrm{p}}}
$$

The heat transport between the external surface of the particle and the gas bulk, can be estimated by the following criterion of Mears [9]:

$$
\frac{\left(\Delta \mathrm{H}_{\mathrm{r}}\right) \cdot\left\{\left(\mathrm{J}_{\mathrm{H}_{2}}\right)_{\max } 1 / \mathrm{V}_{\text {sample }}\right\} \mathrm{d}_{\mathrm{p}}^{2}}{2 \cdot \mathrm{Nu} \cdot \lambda_{\text {gas }} \cdot \mathrm{T}}<0.15 \frac{\mathrm{R} \cdot \mathrm{T}}{\mathrm{E}_{\mathrm{a}}}
$$


The criterion of Anderson can be used to verify if isothermal conditions prevail in the particle [9]:

$$
\frac{\left(\Delta \mathrm{H}_{\mathrm{r}}\right) \cdot\left\{\left(\mathrm{J}_{\mathrm{H}_{2}}\right)_{\max } 1 / \mathrm{V}_{\text {sample }}\right\}}{4 \cdot \lambda_{\text {solid }} \cdot \mathrm{T}}<0.75 \frac{\mathrm{R} \cdot \mathrm{T}}{\mathrm{E}_{\mathrm{a}}}
$$

Table B.1: data used to verify mass and heat transfer effects.

\begin{tabular}{|c|c|c|c|}
\hline \multicolumn{4}{|l|}{ Parameters } \\
\hline$\overline{\mathrm{D}_{\text {reactor }}}$ & $\mathrm{m}$ & $4.0 \cdot 10^{-3}$ & \\
\hline$\rho_{\text {sample }}$ & $\mathrm{kg} / \mathrm{m}^{3}$ & 5263 & \\
\hline$\varepsilon$ & - & 0.63 & \\
\hline$\tau_{\mathrm{p}}$ & - & 3 & \\
\hline$d_{p}$ & $\mathrm{~m}$ & $2.0 \cdot 10^{-4}$ & \\
\hline$\lambda_{\text {solid }}$ & $\mathrm{J} /(\mathrm{m} . \mathrm{s} \cdot \mathrm{K})$ & 175.6 & \\
\hline $\mathrm{D}_{\mathrm{H} 2, \mathrm{~N} 2}$ & $\mathrm{~m}^{2} / \mathrm{s}$ & $3.8 \cdot 10^{-4}$ & \\
\hline$\lambda_{\text {gas }}$ & $\mathrm{J} /(\mathrm{m} . \mathrm{s} . \mathrm{K})$ & 0.0234 & \\
\hline$\Delta \mathrm{H}_{\mathrm{r}}$ & $\mathrm{kJ} / \mathrm{mol}$ & 60 & \\
\hline E & $\mathrm{kJ} / \mathrm{mol}$ & 70 & \\
\hline Parameters & & TPR & Isothermal \\
\hline $\mathrm{T}$ & & 489 & 900 \\
\hline $\mathrm{m}_{\text {sample }}$ & $\mathrm{mg}$ & 270 & 7.6 \\
\hline $\mathrm{V}_{\text {sample }}$ & $\mathrm{m}^{3}$ & $5.13 \cdot 10^{-8}$ & $1.44 \cdot 10^{-9}$ \\
\hline$\eta_{\text {gas }}$ & $\mathrm{kg} /(\mathrm{m} . \mathrm{s})$ & $3.9 \cdot 10^{-5}$ & $4.4 \cdot 10^{-5}$ \\
\hline$\rho_{\text {gas }}$ & $\mathrm{kg} / \mathrm{m}^{3}$ & 0.442 & 0.287 \\
\hline $\mathrm{Cp}_{\text {gas }}$ & $\mathrm{J} /(\mathrm{kg} \cdot \mathrm{K})$ & $29.8 \cdot 10^{3}$ & $33.3 \cdot 10^{3}$ \\
\hline $\mathrm{V}_{\mathrm{gas}}$ & $\mathrm{m} / \mathrm{s}$ & 0.28 & 0.43 \\
\hline $\mathrm{C}_{\mathrm{H} 2}$ & $\mathrm{~mol} / \mathrm{m}^{3}$ & 7.9 & 3.1 \\
\hline $\mathrm{J}_{\mathrm{H} 2 \text {, max }}$ & $\mathrm{mol} / \mathrm{s}$ & $1.3 \cdot 10^{-6}$ & $2.4 \cdot 10^{-6}$ \\
\hline \multicolumn{4}{|l|}{ Results } \\
\hline Equation & Criteria & TPR & Isothermal \\
\hline B.1 & $0.15>$ & $2.0 \cdot 10-4$ & 0.032 \\
\hline B. 3 & $0.03-0.7>$ & $4.7 \cdot 10-4$ & 0.079 \\
\hline B. 4 & $0.021>$ & $7.8 \cdot 10^{-4}$ & 0.033 \\
\hline B. 5 & $0.068>$ & $1.1 \cdot 10^{-7}$ & $4.9 \cdot 10^{-6}$ \\
\hline
\end{tabular}

The results presented in table B. 1 show that all criteria are easily met in the TPR method. The calculated values for the isothermal method show that the criteria for the intra particle heat and mass transfer are close to the maximum. 


\section{Experimental verification}

The influence of the inter particles mass transfer is verified by performing TPR experiments at two different conditions. The sample amount and gas flow are varied in these two experiments, while keeping the space velocity constant. The results are shown in Figure B.1 and it can be seen that a similar TPR profile is obtained under the two different conditions, indicating that inter particle mass transfer does not influence the experimental results.

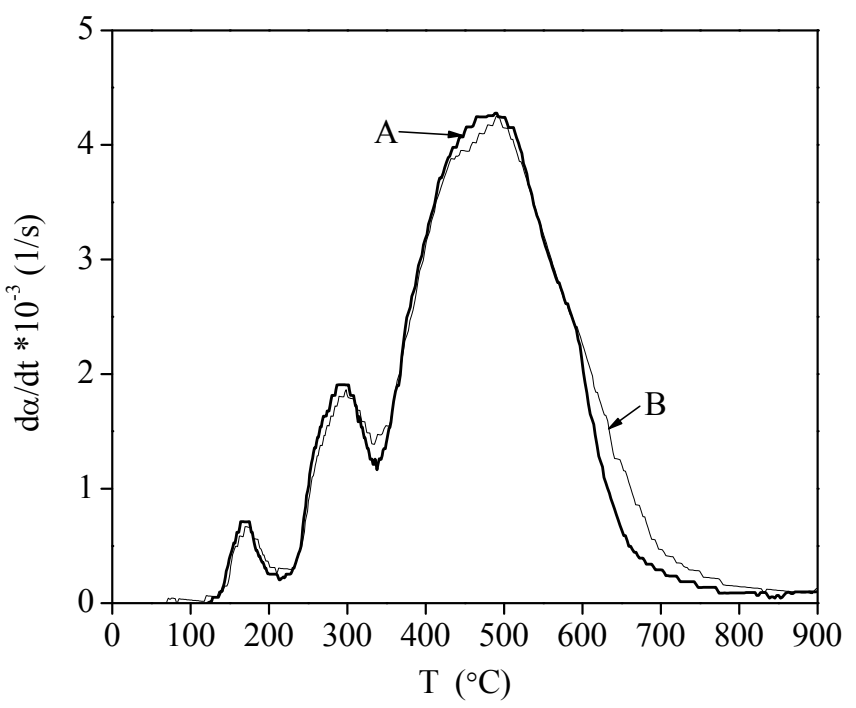

Figure B.1: TPR-profiles different measurements with the same space velocity.

$A: m_{\text {sample }}=134.8 \mathrm{mg}, \varphi_{\mathrm{v}}=40.8 \mathrm{ml} / \mathrm{min}, \beta=5 \mathrm{~K} / \mathrm{min}, \mathrm{T}_{\text {final }}=900{ }^{\circ} \mathrm{C}, 220<\mathrm{d}_{\mathrm{p}}<400 \mu \mathrm{m}$;

B: $m_{\text {sample }}=269.9 \mathrm{mg}, \varphi_{\mathrm{v}}=81.5 \mathrm{ml} / \mathrm{min}, \beta=5 \mathrm{~K} / \mathrm{min}, \mathrm{T}_{\text {final }}=900{ }^{\circ} \mathrm{C}, 220<\mathrm{d}_{\mathrm{p}}<400 \mu \mathrm{m}$.

The influence of the intra particle diffusion is experimentally determined by performing TPR experiments under the same conditions, but varying the particle diameter of the sample. 


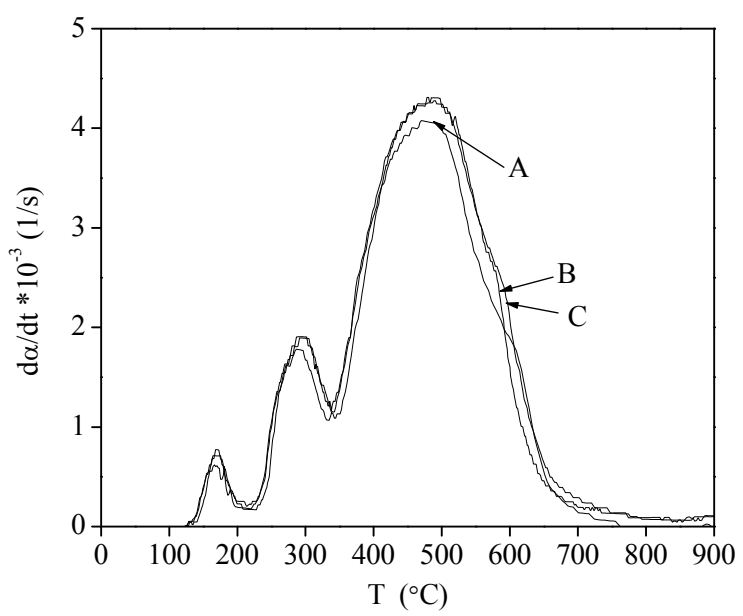

Figure B.2 : TPR profiles of BIC iron oxide with different particle sizes. Experimental conditions: $\varphi_{\mathrm{v}}=81.5 \mathrm{ml} / \mathrm{min}, \beta=5 \mathrm{~K} / \mathrm{min}$, Tfinal $=900{ }^{\circ} \mathrm{C}$ and $\mathrm{m}_{\text {sample }}= \pm 270 \mathrm{mg}$ for all experiments. Particle sizes are : $A=80<d_{p}<125 \mu \mathrm{m} ; B=125<d_{p}<220 \mu \mathrm{m} ; C=220<d_{p}<400 \mu \mathrm{m}$.

Figure B. 2 shows that for particles $>80 \mu \mathrm{m}$ no difference in the TPR profile is observed and apparently the inter particle mass transfer for the measured particle size $80<\mathrm{d}_{\mathrm{p}}<400 \mu \mathrm{m}$ does not influence the measured conversion rate. Measurements with smaller particles $(<80 \mu \mathrm{m})$ are not represent able due to pressure fluctuations during the experiment, what influenced the analysis of the hydrogen concentration. 


\section{Appendix C}

The elemental composition of pyrolysis oil depends on many factors, like biomass feed used and process conditions of the pyrolysis process. Therefore the obtained results in Chapter 7 may fluctuate with the pyrolysis feed. The equilibrium data of the iron oxide for the different cases is shown in Table C.2.

Table C.1: Pyrolysis oil input data Chapter 7

Elemental pyrolysis oil composition

\begin{tabular}{llllll}
\hline & & $\mathrm{C}$ & $\mathrm{H}$ & $\mathrm{O}^{*}$ & $\mathrm{H}_{2} \mathrm{O}$ \\
\hline Pyrolysis oil (wet) & wt \% & 0.37 & 0.09 & 0.54 & 0.32 \\
Pyrolysis oil (dry) & wt \% & 0.54 & 0.08 & 0.38 & \\
\hline
\end{tabular}

*determined by difference

Feed simulation of the pyrolysis oil by using two model compounds.

\begin{tabular}{lllll}
\hline Mole fractions & Mole $\%$ & $\mathrm{C}$ & $\mathrm{H}$ & $\mathrm{O}$ \\
\hline Oil & 1 & 0.30 & 0.54 & 0.16 \\
Simulated oil & 1 & 0.31 & 0.54 & 0.15 \\
$\mathrm{C}_{6} \mathrm{H}_{10} \mathrm{O}_{3}$ & 0.66 & & & \\
$\mathrm{C}_{6} \mathrm{H}_{12} \mathrm{O}_{3}$ & 0.34 & & & \\
\hline
\end{tabular}

Energy data of pyrolysis oil [10].

\begin{tabular}{lll}
\hline & LHV $(\mathrm{MJ} / \mathrm{kg})$ & $\Delta \mathrm{H}_{\mathrm{f}}(\mathrm{MJ} / \mathrm{kg})^{*}$ \\
\hline $\mathrm{H}_{2}$ & 121 & \\
Pyrolysis oil (dry) & 22.4 & -5.3 \\
Pyrolysis oil (wet) & 15.2 & -8.7 \\
\hline
\end{tabular}

* The heat of formation of dry pyrolysis oil, required to calculate reaction enthalpy of the gasification, needed to be determined. The heat of formation is calculated using the LHV and the elemental composition of oil.

Table C.2: Equilibrium ratios of $\mathrm{CO} / \mathrm{CO}_{2}$ and $\mathrm{H}_{2} / \mathrm{H}_{2} \mathrm{O}$ for the reduction of magnetite to wustite.

\begin{tabular}{llll}
\hline & $1 \mathrm{a}, \mathrm{b}$ & $\mathrm{C}$ & \\
& 2 & 20 \\
$\mathrm{P}(\mathrm{bar})$ & 1 & 1 & 920 \\
$\mathrm{~T}_{\text {red }}\left({ }^{\circ} \mathrm{C}\right)$ & 800 & 920 & \\
\hline Equilibrium ratio (molar) & 0.62 & 0.45 & 0.45 \\
$\mathrm{CO} / \mathrm{CO}_{2}$ & 0.67 & 0.32 & 0.32 \\
$\mathrm{H}_{2} / \mathrm{H}_{2} \mathrm{O}$ & &
\end{tabular}




\section{Nomenclature}

\begin{tabular}{|c|c|c|}
\hline$\alpha$ & $(-)$ & Relative conversion of the iron oxide particle \\
\hline$\alpha_{\mathrm{g}}$ & $(-)$ & Relative conversion of a single grain \\
\hline$\alpha_{i}$ & $(-)$ & Conversion at which the crackling reaction is complete \\
\hline $\mathrm{C}_{\mathrm{H} 2,0}$ & $\left(\mathrm{~mol} / \mathrm{m}^{3}\right)$ & Hydrogen concentration in the bulk \\
\hline $\mathrm{C}_{\mathrm{H} 2 \mathrm{O}, 0}$ & $\left(\mathrm{~mol} / \mathrm{m}^{3}\right)$ & Steam concentration in the bulk \\
\hline $\mathrm{C}_{\mathrm{p}}$ & $(\mathrm{J} / \mathrm{molK})$ & Heat capacity \\
\hline $\mathrm{D}_{\text {grain }}$ & $\left(\mathrm{m}^{2} / \mathrm{s}\right)$ & Overall diffusion coefficient in a grain \\
\hline $\mathrm{D}_{\mathrm{R}}$ & $\left(\mathrm{m}^{2} / \mathrm{s}\right)$ & Diffusivity of gas in between the grains \\
\hline $\mathrm{D}_{\text {eff }}$ & $\left(\mathrm{m}^{2} / \mathrm{s}\right)$ & Effective gas diffusivity in a particle \\
\hline $\mathrm{D}_{\mathrm{g}}$ & $\left(\mathrm{m}^{2} / \mathrm{s}\right)$ & Molecular gas diffusion \\
\hline $\mathrm{D}_{\text {reactor }}$ & $(\mathrm{m})$ & Diameter of the reactor \\
\hline$d_{p}$ & $(\mathrm{~m})$ & Particle diameter \\
\hline $\mathrm{E}_{\mathrm{a}}$ & $(\mathrm{J} / \mathrm{mol})$ & Activation energy \\
\hline$\varepsilon$ & $(-)$ & Voidage fraction \\
\hline$\varepsilon_{0}$ & $(-)$ & Initial voidage fraction \\
\hline$\varepsilon_{\mathrm{p}}$ & $(-)$ & Voidage fraction in the particle \\
\hline$f_{s}$ & $(-)$ & Solid fraction \\
\hline $\mathrm{f}_{\mathrm{s} 0}$ & $(-)$ & Initial solid fraction \\
\hline$\eta$ & $(\mathrm{kg} / \mathrm{ms})$ & Viscosity \\
\hline $\mathrm{H}_{\mathrm{r}}$ & $(\mathrm{J} / \mathrm{mol})$ & Heat of reaction \\
\hline $\mathrm{J}_{\mathrm{H} 2}$ & $(\mathrm{~mol} / \mathrm{s})$ & Flux of hydrogen \\
\hline $\mathrm{K}_{\mathrm{e}}$ & $(-)$ & Equilibrium constant \\
\hline $\mathrm{k}_{\mathrm{s}}$ & $(\mathrm{m} / \mathrm{s})$ & Surface reaction rate constant \\
\hline $\mathrm{k}_{\mathrm{v}}$ & $(\mathrm{m} / \mathrm{s})$ & Volumetric reaction rate constant \\
\hline $\mathrm{k}_{\mathrm{g}}$ & $(\mathrm{m} / \mathrm{s})$ & Mass transfer coefficient \\
\hline $\mathrm{m}_{\text {sample }}$ & $(\mathrm{kg})$ & Mass of the sample \\
\hline$\lambda_{\text {solid }}$ & $(\mathrm{J} / \mathrm{msK})$ & Heat transfer coefficient \\
\hline $\mathrm{N}_{\text {grain }}$ & $(-)$ & Number of grains \\
\hline $\mathrm{P}$ & $(\mathrm{Pa})$ & Pressure \\
\hline$\rho$ & $\left(\mathrm{kg} / \mathrm{m}^{3}\right)$ & Density \\
\hline $\mathrm{R}_{\mathrm{p}}$ & $(\mathrm{m})$ & Radius of the particle \\
\hline $\mathrm{R}$ & (m) & Radial location in the particle \\
\hline $\mathrm{R}_{\mathrm{i}}$ & (m) & Radius of the unreacted particle \\
\hline $\mathrm{R}_{0}$ & $(\mathrm{~m})$ & Initial particle radius \\
\hline $\mathrm{R}_{\mathrm{g}}$ & $(\mathrm{J} / \mathrm{molK})$ & Universal gas constant (8.31) \\
\hline$r_{g}$ & $(\mathrm{~m})$ & Grain radius \\
\hline$r_{\mathrm{gi}}$ & (m) & Radius of the unreacted grain \\
\hline$r_{\mathrm{g} 0}$ & $(\mathrm{~m})$ & Initial grain radius \\
\hline $\mathrm{S}_{0}$ & $(\mathrm{~mol})$ & Amount of reactive oxygen atoms in the sample \\
\hline $\mathrm{T}$ & $(\mathrm{K})$ & Temperature \\
\hline $\mathrm{t}$ & (s) & Time \\
\hline$\tau$ & $(\mathrm{s})$ & Time to obtain full conversion of the sample \\
\hline$\tau_{\mathrm{g}}$ & $(\mathrm{s})$ & Time for the grain reaction to complete \\
\hline$\tau_{\mathrm{c}}$ & $(\mathrm{s})$ & Time for the crackling reaction to complete \\
\hline$\tau_{\mathrm{p}}$ & & Tortuosity \\
\hline $\mathrm{V}_{\text {sample }}$ & $\left(\mathrm{m}^{3}\right)$ & Volume of the sample \\
\hline $\mathrm{V}_{\text {gas }}$ & $(\mathrm{m} / \mathrm{s})$ & Space velocity of the gas in the reactor \\
\hline
\end{tabular}




\section{Literature}

1 Bogdandy von, L. and H.-J. Engell, The reduction of iron ores: scientific basis and technology, Berlin, Springer-Verlag, 1971,

2 McKewan, M.C., Transactions of the metallurgical society of AIME, 224 (1962) p. 2

3 Tokuda, M., H. Yoshikoshi, and M. Ohtani, ISIJ International, 13 (1973) p. 350-362.

4 Doraiswamy, L.K. and M.M. Sharma, Heterogeneous reactions: analysis, examples, and reactor design. Vol. I: Gas-Solid and Solid-Solid reactions., New York, John Wiley \& Sons Inc. 1984

5 Szekely, J., J.W. Evans, and H.Y. Sohn, Gas-solid reactions. New York, Academic Press Inc., 1976.

6 Levenspiel, O., Chemical Reactor Omnibook. Corvallis, OR, 1979.

7 Seiler, H., Reduktions-Oxidations zyklen im festbettreaktor mit periodischer stromungsumkehr, in Technical department Friedrich-Alexander University Erlangen, 2001.

8 Park, J.Y. and O. Levenspiel, Chemical engineering science, 30 (1975) p. 1207-1214.

9 Westerterp, K.R., W.P.M. Van Swaaij, and A.A.C.M. Beenackers, Chemical reactor design and operation. New York ,John Wiley \& Sons Ltd. , 1984.

10 Phyllis, Database for biomass and waste, www.ecn.nl/phyllis, Energy research Centre of the Netherlands. 


\section{Publications}

1. M.F.Bleeker, S.R.A Kersten, H.J. Veringa, Pure hydrogen from pyrolysis oil using the steam-iron process, Catalysis Today, 2007, 127 (1-4), p. 278-290.

2. M.F.Bleeker, S.R.A Kersten, H.J. Veringa, Deactivation of iron oxide used in the steam-iron process to produce hydrogen, Applied Catalysis A, 2009, 357 (1), p. 517.

3. M.F. Bleeker, S. Gorter, S.R.A. Kersten, A.G.J. van der Ham, H. van den Berg, H.J. Veringa, Hydrogen production from pyrolysis oil using the steam-iron process. A process design study, Clean Technologies and Environmental Policy Journal, 2009, accepted.

4. M.F.Bleeker, S.R.A Kersten, H.J. Veringa, Pure hydrogen production from pyrolysis oil using the steam-iron process. The effect of temperature and iron oxide conversion in the reduction, Industrial \& Engineering Chemistry Research, submitted.

5. M.F.Bleeker, S.R.A. Kersten, H.J. Veringa, Pure hydrogen from pyrolysis oil using the steam-iron process, Proc. 15 ${ }^{\text {th }}$ EBC\&E, Berlin, Germany, 7-11 May 2007.

6. M.F.Bleeker, S.R.A Kersten, H.J. Veringa, Deactivation of iron oxides in the steam-iron process with pyrolysis oil, Proc. WHTC 2007, Montecatini Terme, Italy, 4-7 Nov. 2007.

7. M.F.Bleeker, S.R.A Kersten, H.J. Veringa, Hydrogen production from pyrolysis oil using the steam-iron process. A process design study, Proc. $18^{\text {th }}$ CHISA, Prague, Czech Republic, 24-28 Aug. 2008.

Posters:

8. IMPACT symposium, Enschede, The Netherlands, 13th April 2007.

9. Netherland Process Technology Symposium 2004 and 2007. 


\section{Dankwoord}

Wat is het een fijn gevoel om eindelijk de laatste woorden te kunnen schrijven van dit proefschrift waar ik enkele jaren aan heb gewerkt! Mede met de hulp en steun van de mensen die hier onder vermeld staan heb ik met veel plezier gewerkt en met dit boekje als resultaat.

Allereerst wil ik mijn promotor Hubert Veringa bedanken voor de kans en het vertrouwen om dit promotie onderzoek te mogen doen. Mede met jouw kennis van de materiaalkunde hebben we het deactivatie model afgeleid (hoofdstuk 6), waar we goed gebruik hebben kunnen maken van eerder gepubliceerd werk van jou. Je enthousiasme over behaalde resultaten heeft motiverend gewerkt. Daarnaast heb ik de vrijheid gehad om het onderzoek zelf in te vullen, wat ik als erg leerzaam heb ervaren.

Ten tweede wil ik Sascha Kersten bedanken voor de dagelijkse ondersteuning. Ik heb veel van je kritische manier van denken geleerd. Zonder jouw hulp en kennis had ik dit proefschrift niet kunnen schrijven.

I would like to thank the commission for their participation, their interets in my work and for their time: professor G. van der Steenhoven, professor J.A.M. Kuipers, professor H. van den Berg, professor H.J. Heeres, professor J.A. Moulijn, professor W. Prins and professor Z.R. Ismagilov.

Het werk gepresenteerd in dit proefschrift is hoofdzakelijk gebaseerd op experimentele resultaten, welke ik heb verkregen uit opstellingen in het hoge druk laboratorium (HDL). Ik wil iedereen van het HDL bedanken voor de gezellige tijd en voor het verrichten van alle kleine en grote klusjes die noodzakelijk zijn voor het uitvoeren van de experimenten. Met name tijdens mijn zwangerschappen, waarin ik minder zelf kon doen (olie bijvullen en filtreren, tillen etc.), wil ik jullie bedanken voor de ondersteuning. Jeffry Karstenberg startte met de bouw van de "wervelbed" opstelling, welke later door Karst van Bree is afgemaakt. Johan Agterhorst heeft een begin gemaakt aan de "gepakte bed" opstelling welke later door Karst en Benno Knaken (de dubbele ring onderin de glazen reactor heeft heel wat bezoekjes aan de glasblazers voorkomen) zijn aangepast.

I would like to thank professor Zinfer Ismagilov for his hospitality during my visit to the Boreskov Institute of Catalysis (BIC), which I enjoyed very much. The iron 
oxide applied in this research obtained from your institute (referred to as BIC iron oxide) was applied successfully to generate hydrogen in the steam-iron process and was very helpful in this research.

Henk van den Berg en Louis van der Ham wil ik bedanken voor het gebruiken van mijn onderwerp in het vak Process Plant Design. Hieruit is hoofdstuk 7 voortgekomen waaraan met name ook Sander Gorter een grote bijdrage heeft geleverd en welke we op CHISA in Praag hebben gepresenteerd.

De afstudeerstudenten Coen van Kralingen, Berza Ataoglu, Peter Koehorst, Xavier Portas Buron en Sander Gorter wil ik bedanken voor hun bijdrage in het onderzoek. Het was altijd verfrissend om met jullie samen te werken aan het onderzoek!

Dr. K. Seshan wil ik bedanken voor de mogelijkheid voor het gebruik van een aantal faciliteiten in de vakgroep Catalytic Processes and Materials, waaronder de TGA. Louise Vrielink (BET, XRF), Mark Smithers (SEM) en Erik Schuring (XRD, SEM) bedankt voor het uitvoeren van de analyses van mijn ijzeroxide samples.

Thanks to all my colleagues my time in the TCCB group has been great. I enjoyed the borrels, BBQ's and coffee breaks, the wadlopen, skiing and sailing events and also the courses, symposia and conferences that we shared together.

Yvonne Bruggert-ter Huurne wil ik bedanken voor het helpen regelen van mijn verdediging en voor alle andere secretariële zaken die je voor me hebt gedaan de afgelopen jaren.

De paranimfen Elly Hoekstra and Doortje Grunder wil ik bedanken voor hun inzet en hulp bij de laatste voorbereidingen van mijn verdediging.

Mijn ouders zijn een grote steun geweest tijdens mijn studie en promotie, maar met name het afgelopen jaar was ik blij dat ik op jullie kon rekenen.

Tenslotte wil ik Sander bedanken voor zijn morele steun, maar ook voor zijn hulp bij de voorbereiding van presentaties en de opmaak van dit proefschrift. Je geduld en zorgzaamheid waardeer ik erg, maar boven alles ben je een fantastische vader voor onze kinderen! Guido en Lucie bedank ik voor dat zij mij elke dag eraan herinneren om te genieten van de simpele dingen in het leven. 


\section{About the author}

Mariken Bleeker was born on the 5th of June 1978 in Zoetermeer, the Netherlands. She studied Chemical Engineering at the University of Twente. She did her internship for three months at Roche A.G., Vitamins, R\&D Department, Basel, Switzerland (2000). In May 2002 she graduated on the subject "Supercritical water gasification of glucose in quartz capillary reactor" under the supervision of Biljana Potic. In that period she also set up a short practical biomass course for secondary school students at the University of Twente. She started with her PhD in the group Thermo-Chemical Conversion of Biomass at the University of Twente with Prof. Dr. Ir. H.J. Veringa on the subject " Pure hydrogen production out of biomass derived fuel, using the steam-iron process" in November 2003. Since August 2009 she is employed by HoSt BV in Hengelo.

During her studies she was active in boards and committees of which one was being member of the board of the study association C.T.S.G Alembic ('97/'98). Her main task was the organization of the study tour to Brazil and Argentina in March/April 1999. In the summer of 2000 she did voluntary work in Jarabacoa, Dominican Republic. In 2002/2003 she travelled for 8 months in Asia. 